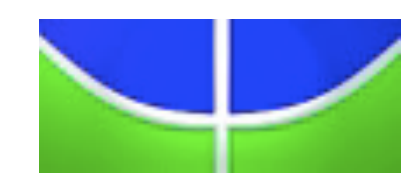

Universidade de Brasília

Instituto de Letras

Departamento de Linguística, Português e Línguas Clássicas

Programa de Pós-Graduação em Linguística

\title{
TERMINOGRAFIA EM LÍNGUA DE SINAIS BRASILEIRA: PROPOSTA DE GLOSSÁRIO ILUSTRADO SEMIBILÍNGUE DO MEIO AMBIENTE, EM MÍDIA DIGITAL
}

Cristiane Batista do Nascimento

Brasília - DF 


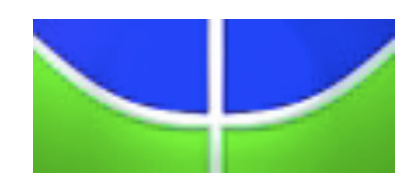

Universidade de Brasília

Instituto de Letras

Departamento de Linguística, Português e Línguas Clássicas

Programa de Pós-Graduação em Linguística

\section{TERMINOGRAFIA EM LÍNGUA DE SINAIS BRASILEIRA: PROPOSTA DE GLOSSÁRIO ILUSTRADO SEMIBILÍNGUE DO MEIO AMBIENTE, EM MÍDIA DIGITAL}

Cristiane Batista do Nascimento

Tese de Doutoramento submetida ao curso de PósGraduação em Linguística, Departamento de Linguística, Português e Línguas Clássicas, Instituto de Letras da Universidade de Brasília, como requisito parcial para a obtenção do grau de Doutora em Linguística.

Área de Concentração: Teoria e Análise Linguística. Linha de Pesquisa: Léxico e Terminologia

Orientadora: Professora Doutora Enilde Leite de Jesus Faulstich

Brasília - DF 
Ficha catalográfica elaborada automaticamente, com os dados fornecidos pelo(a) autor(a)

Nascimento, Cristiane Batista do
NN244t Terminografia em Lingua de Sinais Brasileira: Proposta de Glossário Ilustrado Semibilíngue do Meio Ambiente, em mídia digital / Cristiane Batista do Nascimento; orientador Enilde Leite de Jesus Faulstich. -- Brasília, 2016.

$222 \mathrm{p}$.

Tese (Doutorado - Doutorado em Linguística) -Universidade de Brasília, 2016.

1. Glossário Semibilíngue. 2. Terminografia. 3. Língua de Sinais Brasileira. 4. Criação de sinais. 5. Política de ensino. I. Faulstich, Enilde Leite de Jesus, orient. II. Título. 


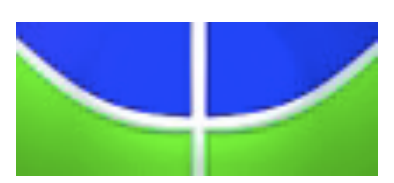

Universidade de Brasília - UnB

Instituto de Letras - IL

Departamento de Linguística, Português e Línguas Clássicas - LIP

Programa de Pós-Graduação em Linguística - PPGL

\section{Banca Examinadora:}

Professora Doutora Enilde Leite de Jesus Faulstich Orientadora (Presidente) - LIP/IL/UnB

Professora Doutora Cleide Lemes da Silva Cruz Membro Efetivo - IFB

Professora Doutora Fatima Ali Abdalah Abdel Cader Nascimento Membro Efetivo - UDF

Professora Doutora Heloisa Maria Moreira Lima Salles Membro Efetivo - LIP/IL/UnB

Professora Doutora Sandra Patrícia de Faria do Nascimento Membro Efetivo - SEEDF/GDF

Professora Doutora Rozana Reigota Naves Suplente - LIP/IL/UnB 
DEDICATÓRIA

Para minha mãe, Itamar Batista, meu exemplo de vida. 


\section{AGRADECIMENTOS}

A Deus, pai amoroso, a Deus filho, Jesus, meu grande amigo e a Deus Espírito Santo, meu consolador nos momentos difíceis. Porque sem Ti, trindade divina, eu nada faria.

A minha orientadora, Dra. Enilde Faulstich, todo meu afeto e gratidão pelas horas de dedicação, de ensinamentos fundamentais na minha caminhada acadêmica. Muito obrigada por fazer de mim uma sementinha regada que começa a florescer.

A minha amada família, minha mãe, Itamar, meu pai, Jorge, meus irmãos, Viviane e Jefferson e ao meu noivo, Elio Filho, toda minha gratidão pelo amor, suporte e incentivos constantes.

À Coordenação de Aperfeiçoamento de Pessoal de Nível Superior (CAPES), pelo apoio financeiro por meio da bolsa de doutorado sanduíche no exterior.

À professora Sandra Patrícia Faria-Nascimento, pelas discussões, orientações, ensinamentos, apoio e amizade.

Ao Messias Costa, pela fundamental participação como colaborador, participante e ator surdo. Muito obrigada por ter dedicado tantas horas do seu tempo nesta pesquisa.

À professora Rozana Naves, pelas sugestões e correções da tese no Exame de Qualificação.

À Escola Bilíngue Libras e Português Escrito de Taguatinga, pelas portas abertas para que eu pudesse realizar essa pesquisa. Em especial, a professora Laysa Juntoli que contribuiu com os seus conhecimentos de especialista em Ciências Biológicas e aos seus alunos do $8^{\circ}$ e $9^{\circ}$ ano do turno matutino de 2014.

Aos professores da Gallaudet University em Washington, Distrito da Columbia, Estados Unidos, MJ Bienvenu, pelas orientações, Lindsay Dunn e Felicia Williams, pelos ensinamentos.

Aos participantes surdos, Adriana Gomes, Francisca Vanete, Falk Moreira, Fátima Félix, Gláucio Castro Junior, Logan Marble, Roberta Lima e Rogério Feitosa.

Aos colaboradores dessa pesquisa. Sou muito grata a todos que participaram deste trabalho, em especial aos voluntários. Meu agradecimento à Maísa Veras, bióloga, que me ajudou com a maioria das ideias para a criação das ilustrações do glossário.

A minhas colegas do Centro de Estudos Lexicais e Terminológicos (Centro Lexterm), Tuxi, Michelle, Cleide, Altaci, Daniela, Flávia e Rebeca, pelas discussões e sugestões.

A Anna Salles, minha amiga e revisora, pela leitura cuidadosa do meu texto. 
EPÍGRAFE

"Os limites da minha linguagem significam os limites do meu universo" Wittgenstein 


\section{RESUMO}

Esta tese se insere na linha de pesquisa Léxico e Terminologia e foi desenvolvida no Centro de Estudos Lexicais e Terminológicos (Centro Lexterm) e no Laboratório de Linguística de Língua de Sinais (LabLibras), da Universidade de Brasília. O objeto de estudo é a Terminologia do Meio Ambiente na Língua de Sinais Brasileira (LSB), assim como a criação e a validação de novas unidades terminológicas nesta língua. O objetivo principal deste trabalho foi desenvolver um glossário ilustrado semibilíngue da área de Meio Ambiente, com vistas à escolarização de surdos do Ensino Fundamental II. Para o desenvolvimento da obra terminográfica, fundamentamo-nos no planejamento de corpus e para isso, tomamos como aportes teóricos as áreas de Lexicologia, Lexicografia, Terminologia e Terminografia. Os procedimentos metodológicos adotados foram: (i) recolha de termos da área do Meio Ambiente para criação de fichas lexicográficas em Língua Portuguesa (LP) com base no modelo de Faulstich (2010); (ii) busca de definições dos termos em obras lexicográficas de referência; (iii) reformulação das definições extraídas de materiais lexicográficos diversos; (iv) recolha dos termos do Meio Ambiente na LSB; (v) organização dos termos em campos temáticos e preparação de materiais visuais para a apreensão de conceitos do Meio Ambiente; (vi) promoção das sessões de criação de sinais-termo; (vii) promoção das sessões de validação de sinais-termo; (viii) armazenamento dos termos em LSB; (ix) criação das ilustrações dos termos do Meio Ambiente e revisão por especialistas; (x) desenho do modelo do glossário para criação do suporte em mídias digitais; (xi) descrição da composição fonológica dos sinais-termo para busca pelo sinal no suporte digital e; (xii) registro dos dados no suporte digital. A partir dessas etapas, criamos o Glossário Ilustrado do Meio Ambiente LibrasPortuguês - GIMALP, um modelo terminográfico online que apresenta três mecanismos de acesso aos verbetes: pela LSB, pela LP e pela ilustração. A busca pela LSB pode ser feita pelos três principais parâmetros, a saber: configuração de mão, locação e movimento. Esse tipo de busca é uma inovação para lexicografia e para a Terminologia da LSB. Ademais, o glossário contribui com as reivindicações da comunidade surda de respeito às suas singularidades linguísticas de acesso às informações em Língua de Sinais.

Palavras-chave: Glossário Semibilíngue, Terminografia, Língua de Sinais Brasileira, Terminologia, Criação de sinais, Política de ensino. 


\begin{abstract}
This dissertation follows the Lexical and Terminology research line and was conducted at the Center for Terminological and Lexical Studies (LexTerm Center) and at the Laboratory of Brazilian Sign Language (LabLibras), of the University of Brasília. The study focuses on Terminology of Environment in the Brazilian Sign Language (LSB), as well as the creation and validation of new terminological units in this language. The main objective of this study was to develop a semi-bilingual illustrated glossary in the field of Environment, with the aim of providing junior high school deaf students with schooling. For the development of the terminological work, we based the study on the planning of corpus, and for that purpose we took Lexicology, Lexicography, Terminology and Terminography areas as theoretical support. The methodological procedures adopted were: (i) collection of terms of the area of Environment for the making of lexicography records in the Portuguese Language (PL) based on the Faulstich model (2010); (ii) search for definitions of terms in lexicographic works of reference; (iii) reformulation of the definitions extracted from diverse lexicographic materials; (iv) collection of terms of Environment in LSB; (v) organization of the terms in thematic fields and arrangement of visual materials for apprehension of Environment concepts; (vi) promotion of the sections of sign-terms creation; (vii) promotion of sections of validation of sign-terms; (viii) storage of terms in LSB; (ix) creation of the illustration of the terms of Environment and review by specialists; (x) drawing of the model of the glossary for creation of the support in digital media; (xi) description of the phonological composition of the signterms for search for the sign in the digital support and; (xii) registration of the data on the digital support. Out of these stages we created the Libras-Portuguese Illustrated Glossary of Environment - LPIGE, a terminographic online model which presents three mechanisms of access to the entries: through LSB, PL and illustration. The search through LSB can be done through the three main parameters, namely: handshape, location and movement. This type of search is an innovation for lexicography and for terminology of LSB. Moreover, the glossary contributes with the claims of the deaf community regarding their linguistic singularities for access to the information in Sign Language.
\end{abstract}

Keywords: Semi-bilingual Glossary, Terminography, Brazilian Sign Language, Terminology, Creation of Signs, Teaching Policy. 


\section{LISTA DE ILUSTRAÇÕES}

Figura 1 - Sinais da ASL CLOSE-FRIENDS e DIVORCE …................................................ 31

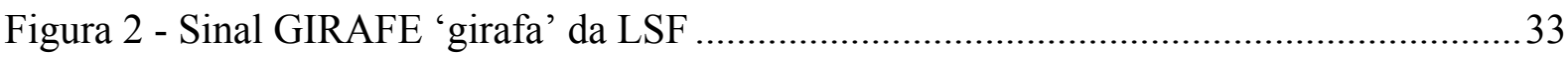

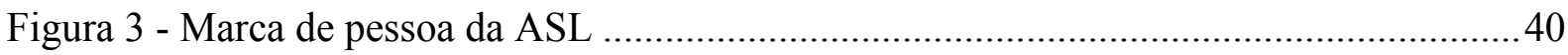

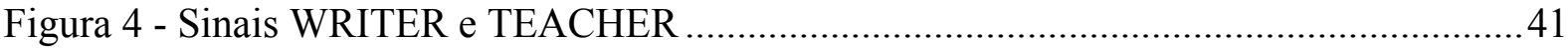

Figura 5 - Sinais CHINESE SCRIPT e UNREADABLE PRINTOUT ................................ 42

Figura 6 - Sinal AUSTRÁLIA em ASL e sinal AUSTRÁLIA emprestado da AUSLAN.......45

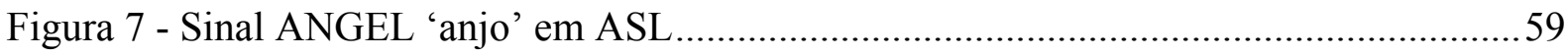

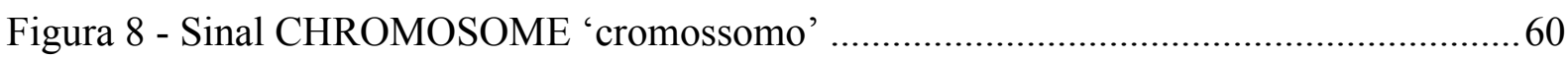

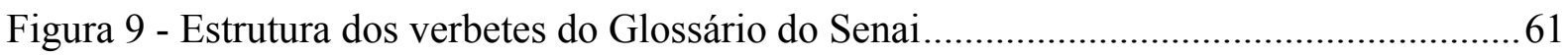

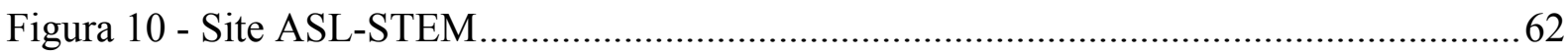

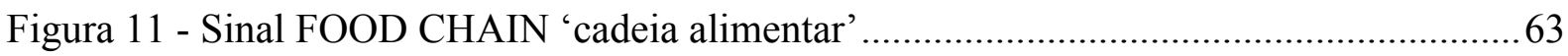

Figura 12 - Site do Glosario Ciencia en Señas da LSV ........................................................64

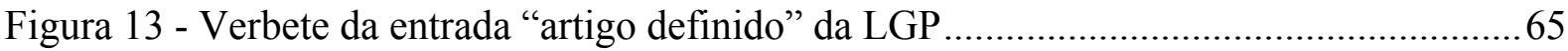

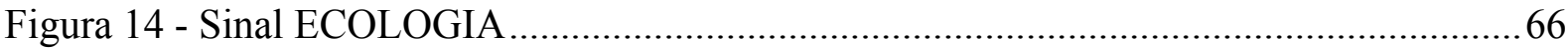

Figura 15 - Verbete do sinal CONECTIVO do Glossário do Letras Libras da UFSC .............67

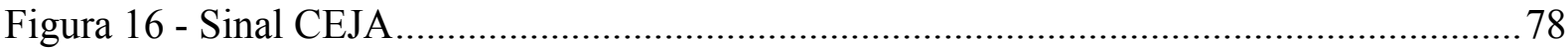

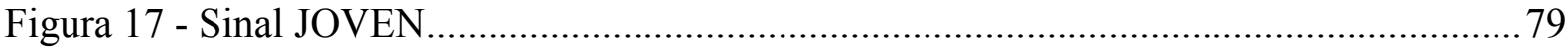

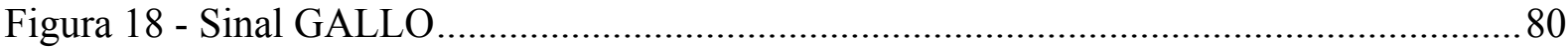

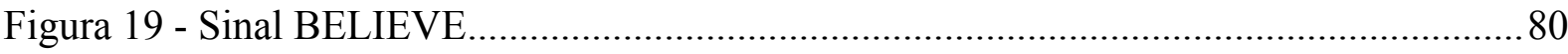

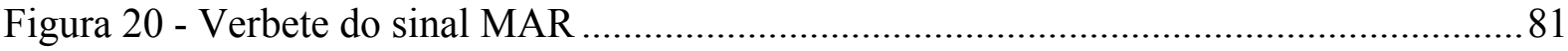

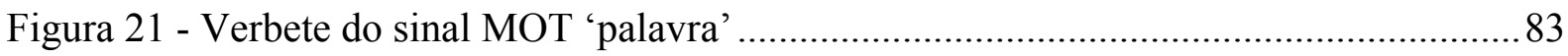

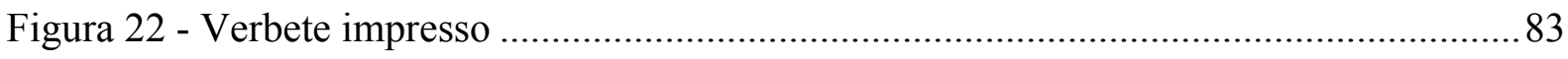

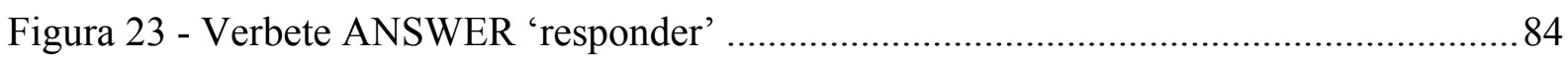

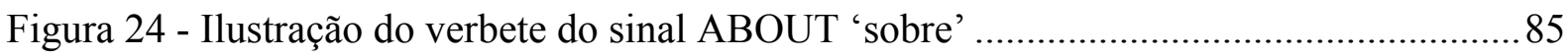

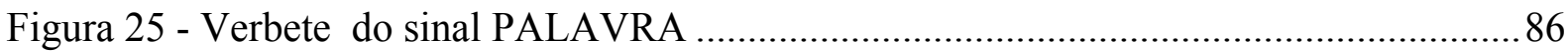


Figura 26 - Aplicativos e recurso de tecnologia assistiva 87

Figura 27 - Site do Jornal Folha de S. Paulo .93

Figura 28 - Organização das pastas com os sinais-termo, as variantes e os plurais 108

Figura 29 - Ilustrações catadores e atmosfera 109

Figura 30 - Ilustrações bactéria e clima. 110

Figura 31 - Ilustrações coleta seletiva e tráfico de animais 110

Figura 32 - Sinal FURACÃO 121

Figura 33 - Base dos sinais do grupo 1 140

Figura 34 - Sinais do grupo 1 140

Figura 35 - Base dos sinais do grupo 2

Figura 36 - Sinais relacionados à cadeia alimentar

Figura 37 - Sinal ENERGIA, que motivou parte dos sinais do grupo 3

Figura 38 - Sinal AUMENTO-DA-TEMPERATURA

Figura 39 - Sinal BALEIA e BALEIA-JUBARTE

Figura 40 - Sinal FÓSSIL

Figura 41 - Sinal PROTEÇÃO, base dos sinais do grupo 8 .

Figura 42 - Sinal PODRE, base dos sinais do grupo 10

Figura 43 - Configuração de mão base dos sinais do grupo 11

Figura 44 - Sinais do grupo 11

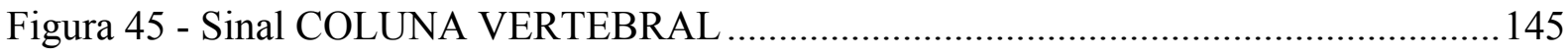

Figura 46 - Sinal ESPÉCIE ..................................................................................... 146

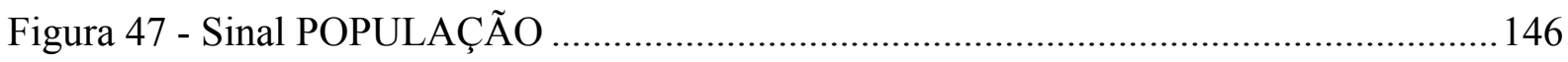

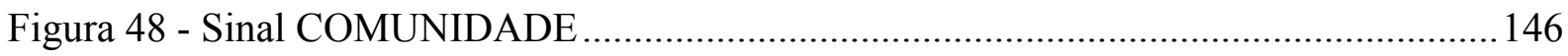

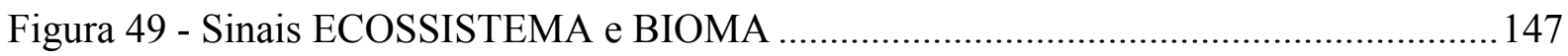

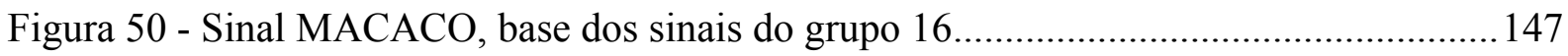

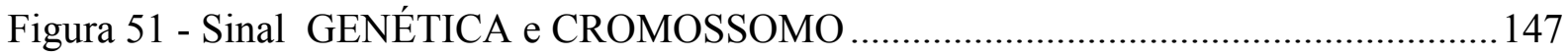

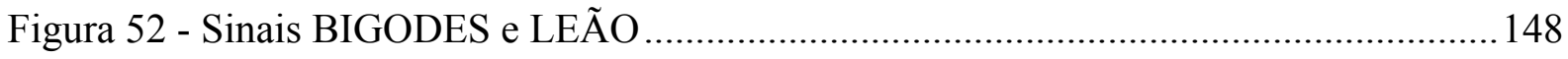


Figura 53 - Sinal CIGARRO, base dos sinais do grupo 20 148

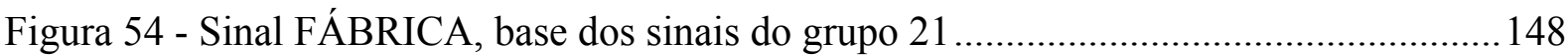

Figura 55 - Sinal MARÉ. 149

Figura 56 - Sinais do grupo 24 149

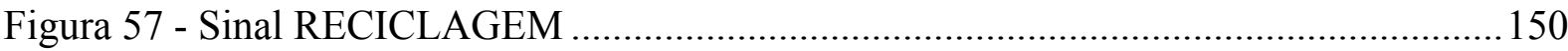

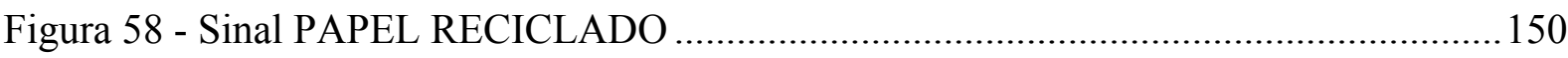

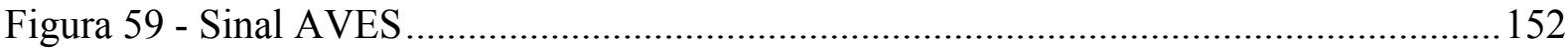

Figura 60 - Sinais BALEIA e BALEIA JUBARTE ........................................................... 159

Figura 61 - Sinais CONFERÊNCIA DAS PARTES e PAPEL RECICLADO ...................... 161

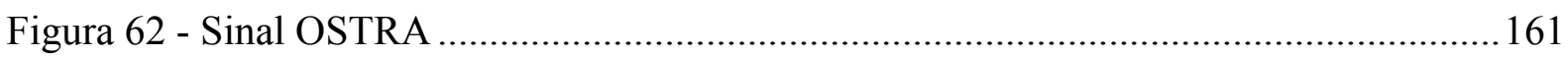

Figura 63 - Sinais CÉLULA ANIMAL e CÉLULA VEGETAL ........................................... 162

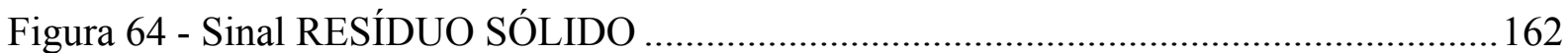

Figura 65 - Sinais TRÁFICO DE ANIMAIS e OCEANO..................................................... 162

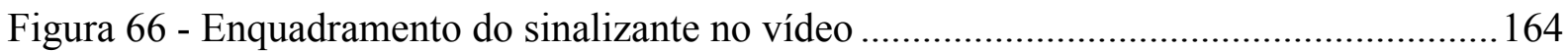

Figura 67 - Quadro de CMs de Faria-Nascimento (2009).................................................. 167

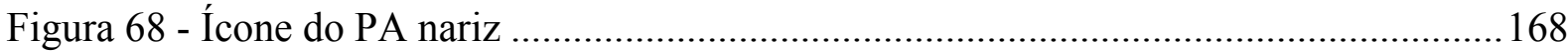

Figura 69 - Representação do ícone do movimento de fechar a mão ...................................... 171

Figura 70 - Descrição dos parâmetros iniciais do sinal ÁGUA DOCE.................................. 178

Figura 71 - Descrição dos parâmetros iniciais do sinal GELO ............................................. 178

Figura 72 - Descrição dos parâmetros iniciais do sinal FELINO ........................................... 179

Figura 73 - Descrição dos parâmetros iniciais do sinal FURACÃO ..................................... 179

Figura 74 - Descrição dos parâmetros iniciais do sinal AQUECIMENTO GLOBAL .......... 180

Figura 75 - Descrição dos parâmetros iniciais do sinal PAPEL RECICLADO ...................... 180

Figura 76 - Início do sinal URBANIZAÇÃO .................................................................. 181

Figura 77 - Página inicial do GIMALP ........................................................................... 183

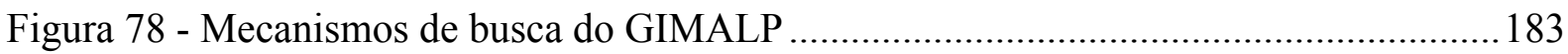

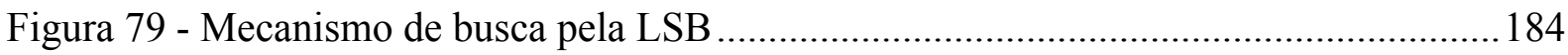


Figura 80 - Mecanismo de busca pela LP

Figura 81 - Mecanismo de busca pelas ilustrações............................................................... 185

Figura 82 - Link de acesso ao verbete a partir da ilustração ................................................. 186

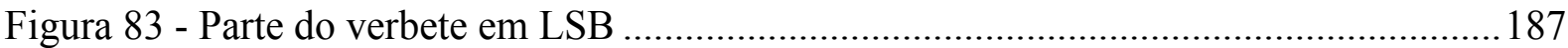

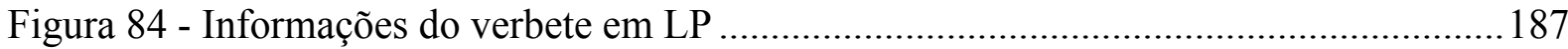

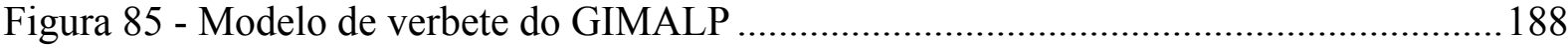

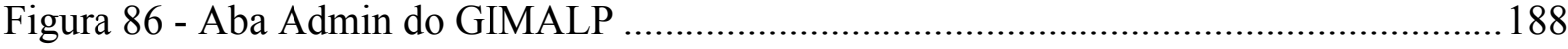

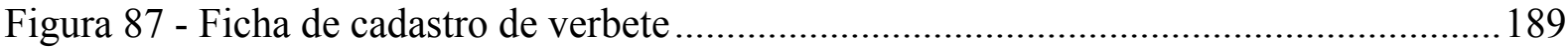

Figura 88 - Espaço para cadastrar a(s) variante(s) em LP ................................................. 191

Figura 89 - Espaço para cadastrar ilustrações ....................................................................... 191

Figura 90 - Como usar o GIMALP restringindo as opções de entrada ................................. 194

Figura 91 - Busca por sinal em condição de dominância e início do sinal ALGA ............... 195

Figura 92 - Busca de sinal que viola as condições de simetria e de dominância ................... 195 


\section{LISTA DE QUADROS}

Quadro 1 - Mapeamento duplo para "intimidade é proximidade"

Quadro 2 - Quadro de CLs da ASL, da BSL e da LSB adaptado de Brennan (1990, p. 62)....35

Quadro 3 - Modelo de ficha lexicográfica da área do Meio Ambiente 97

Quadro 4 - Ficha de reformulação de alga 99

Quadro 5 - Ficha de reformulação de catador de lixo 100

Quadro 6 - Ficha de reformulação de leopardo 100

Quadro 7 - Ficha de reformulação de melanismo 101

Quadro 8 - Sinais-digitados 113

Quadro 9 - Sinais semidigitados 114

Quadro 10 - Sinais-siglas. 114

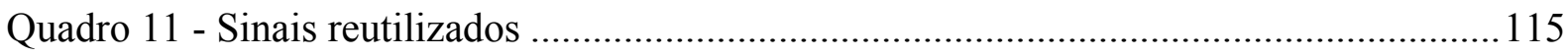

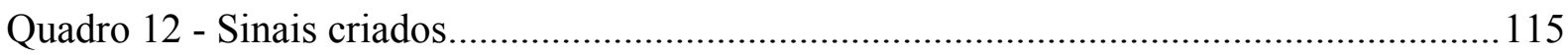

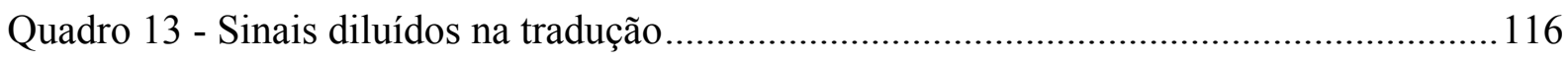

Quadro 14 - Análise dos livros ilustrados e dos dicionários ............................................... 119

Quadro 15 - Quadro de controle dos sinais-termo......................................................... 130

Quadro 16 - Sinais motivados por logotipo ................................................................ 155

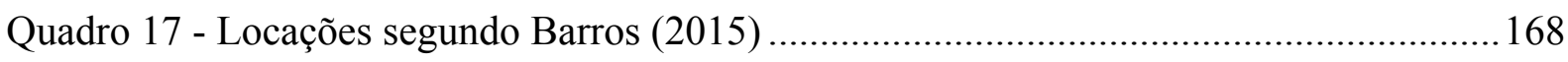

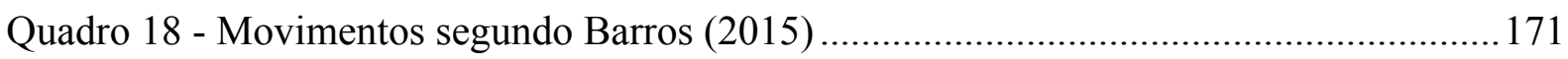

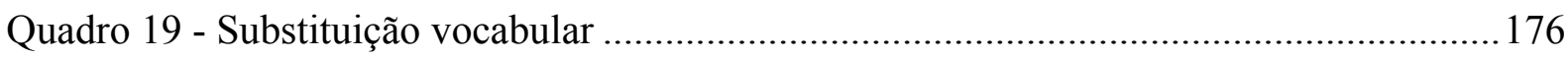

Quadro 20 - Ficha dos parâmetros iniciais para a descrição fonológica dos sinais-termo ..... 177

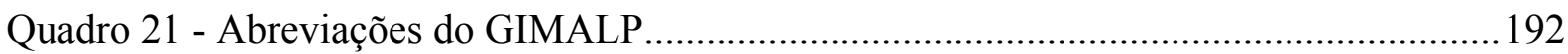




\section{LISTA DE ABREVIATURA E SIGLAS}

AD - Aulete Digital

ASL - Língua de Sinais Americana

AUSLAN - Língua de Sinais Australiana

BSL - Língua de Sinais Britânica

CBN - Cristiane Batista do Nascimento

CM - Configuração de mão

CMs - Configurações de mão

CL - Classificador

CLs - Classificadores

DIMA - Dicionário Ilustrado de Meio Ambiente

DH - Dicionário Houaiss

EBT - Escola Bilíngue Libras e Português-Escrito de Taguatinga

ENM - Expressões não manuais

EF - Expressão facial

EC - Expressão corporal

GBNDES - Glossário de termos usados em atividades agropecuárias, florestais e ciências ambientais

GIMALP - Glossário Ilustrado do Meio Ambiente Libras - Português

LIBRAS - Língua de Sinais Brasileira

LS - Língua de Sinais

LSB - Língua de Sinais Brasileira

LO - Língua oral

LP - Língua Portuguesa

L1 - Primeira língua

L2 - Segunda língua

M - Movimento

MA - Meio Ambiente

PA - Ponto de articulação

VAI - Vocabulário Ambiental Infantojuvenil

VIBGE - Vocabulário Básico de Recursos Naturais e Meio Ambiente 


\section{SUMÁRIO}

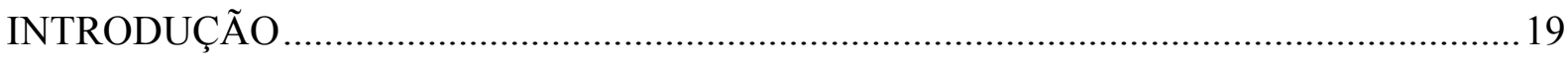

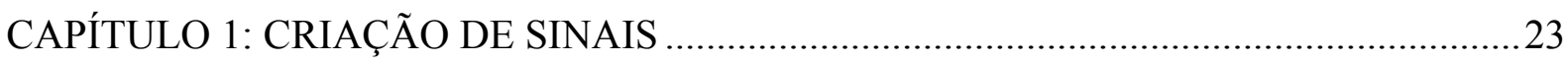

1.1 A estrutura e os tipos de sinais ...........................................................................23

1.2 Mecanismos de criação de sinais ....................................................................28

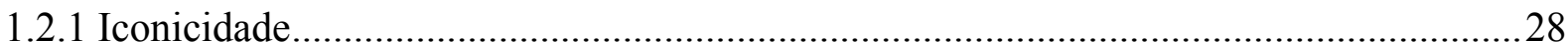

1.2.1.1 Mecanismos semânticos: Metáforas e Metonímias ........................................................ 30

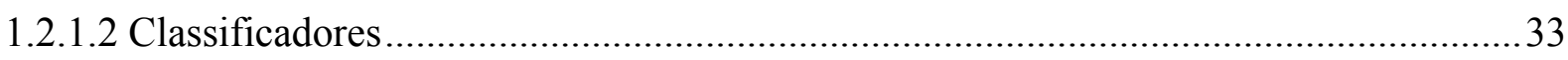

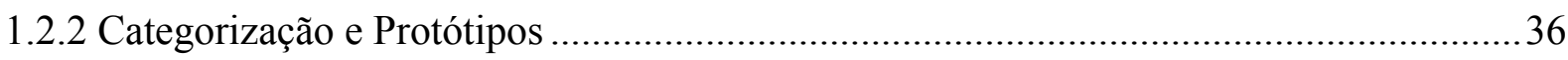

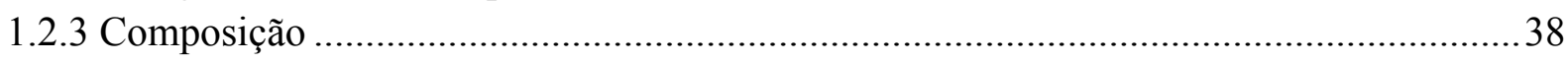

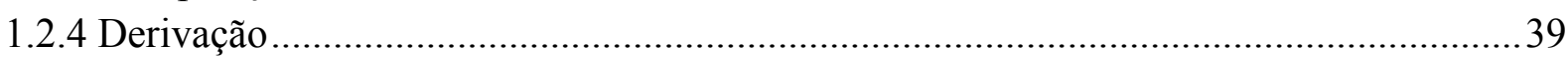

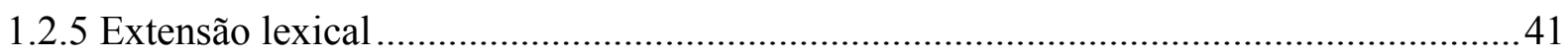

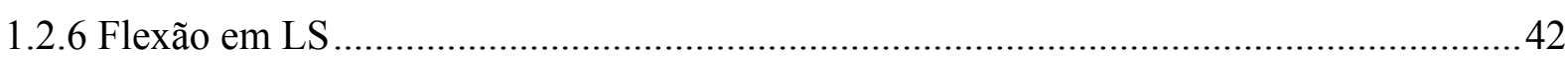

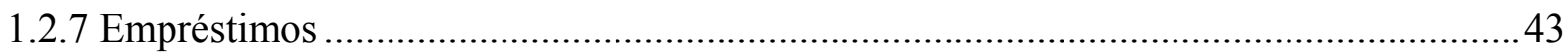

1.3 Restrições na criação de sinais .................................................................................46

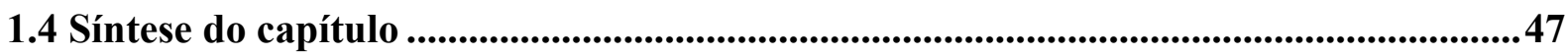

CAPÍTULO 2: TERMINOLOGIA E LEXICOGRAFIA DA LÍNGUA DE SINAIS .............48

2.1 Os desafios da lexicografia das línguas de sinais ..............................................................48

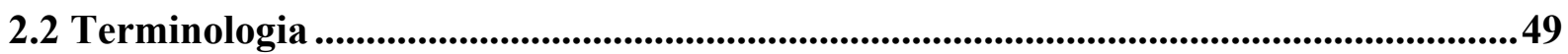

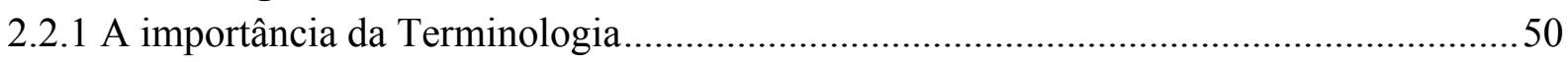

2.3 A terminologia em Língua de Sinais diante das políticas linguísticas ..........................52

2.3.1 Os marcos legais e os direitos linguísticos dos surdos no Brasil....................................54

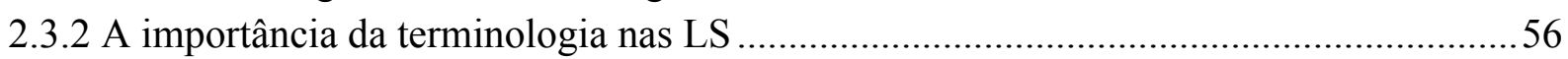

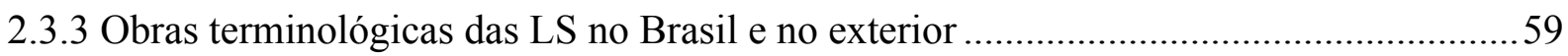

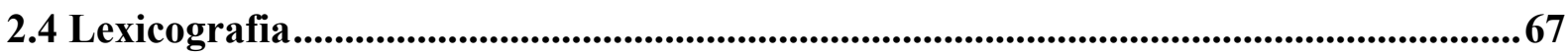

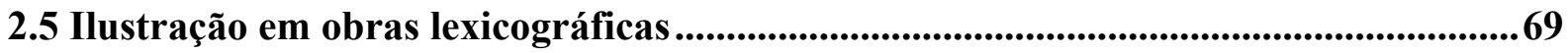

2.6 Lexicografia das Línguas de Sinais .........................................................................73

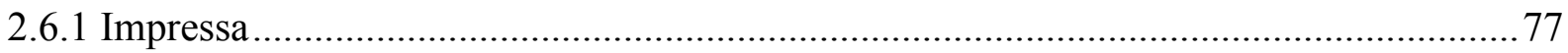

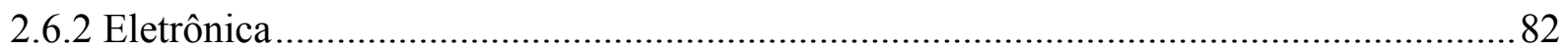

2.7 Definição no âmbito da lexicografia para surdos ......................................................88

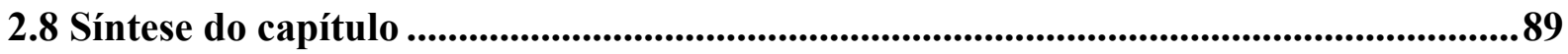

CAPÍTULO 3: PROCEDIMENTOS METODOLÓGICOS ................................................. 91

3.1 O público-alvo e as suas singularidades ........................................................................91

3.2 Procedimentos metodológicos em 15 passos..................................................................92

3.2.1 A recolha de termos da área do Meio Ambiente para composição de fichas

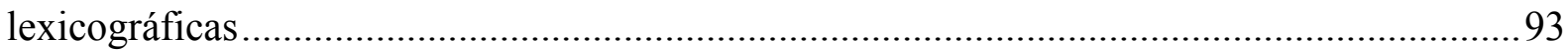

3.2.2 Criação de fichas lexicográficas em LP dos termos selecionados................................. 94

3.2.3 Busca de definições dos termos em obras lexicográficas e terminográficas de referência

3.2.4 Reformulação das definições extraídas de materiais lexicográficos existentes e

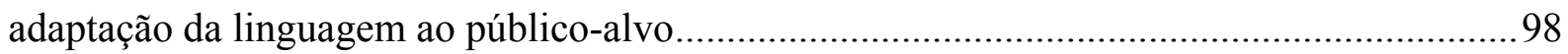


3.3 Etapas desenvolvidas na criação de sinais-termo

3.3.1 Organização dos termos em campos temáticos e preparação de materiais visuais para apreensão de conceitos 105

3.3.2 Pesquisa e identificação de termos do Meio Ambiente na LSB ..................................... 106

3.3.3 Promoção das sessões de criação e validação de sinais-termo ....................................... 107

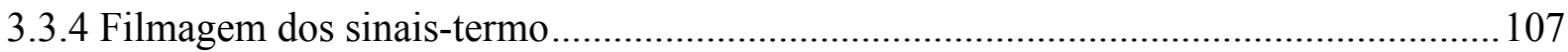

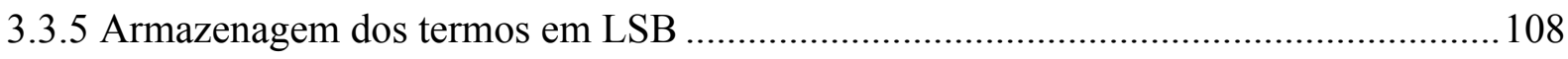

3.4 Criação das ilustrações dos termos do Meio Ambiente e a revisão por especialistas

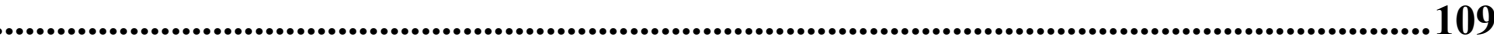

3.5 Síntese do capítulo ...................................................................................................................... 110

CAPÍTULO 4: OS SINAIS-TERMO DO GLOSSÁRIO DO MEIO AMBIENTE:

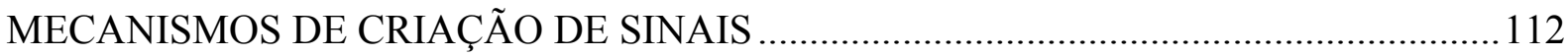

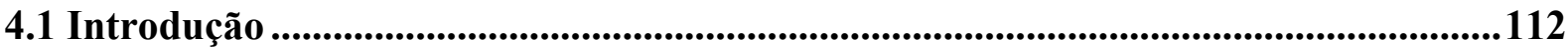

4.2 Sinais do Meio Ambiente existentes: busca de registro em materiais diversos ........112

4.2.1 Busca de sinais do Meio Ambiente no site Legenda Libras......................................... 113

4.2.2 Busca de sinais nos livros ilustrados e nos dicionários da LSB ................................. 116

4.2.2.1 Obra 1: Livro ilustrado de Língua Brasileira de Sinais: desvendando a comunicação

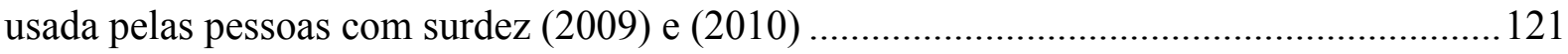

4.2.2.2 Obra 2: Livro ilustrado de Língua Brasileira de Sinais: desvendando a comunicação

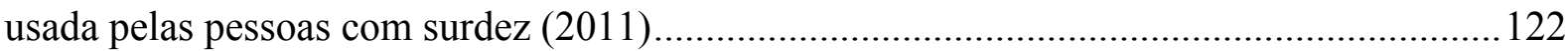

4.2.2.3 Obra 3: Dicionário da Língua Brasileira de Sinais: LIBRAS versão 2.0 (2006) ........ 123

4.2.2.4 Obra 4: Dicionário enciclopédico ilustrado trilíngue da Língua de Sinais Brasileira 124

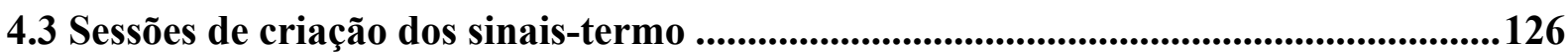

4.3.1 Perfil dos participantes das sessões de criação .......................................................... 126

4.3.2 Tentativas de sessões de criação com participantes da Educação básica: Ensino Médio e

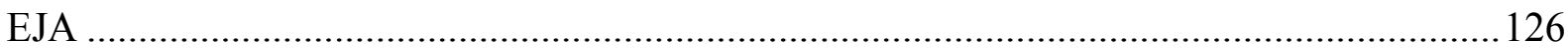

4.3.3 Procedimentos adotados nas sessões de criação .......................................................... 127

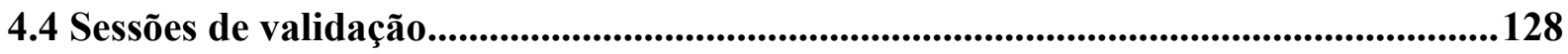

4.4.1 Perfil dos participantes das sessões de validação .......................................................... 128

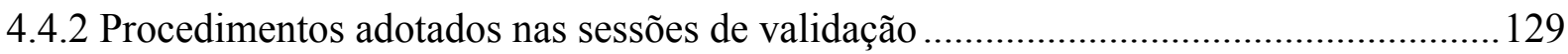

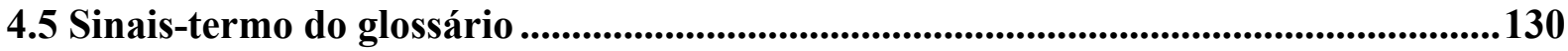

4.6 Descrição dos mecanismos de criação dos sinais-termo do Meio Ambiente .............139

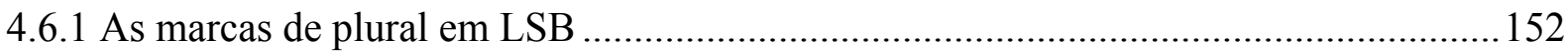

4.6.2 As expressões não manuais nos sinais-termo do Meio Ambiente ................................... 153

4.6.3 Marcas de negação e ausência na criação lexical em LSB ........................................... 153

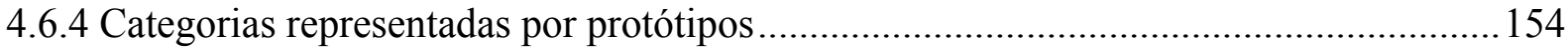

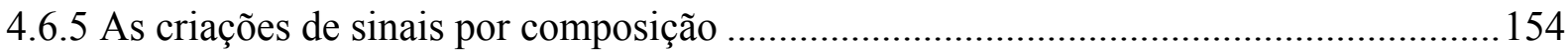

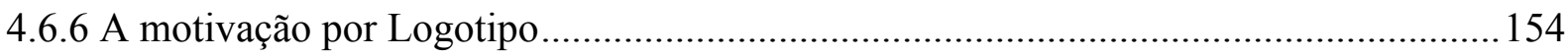

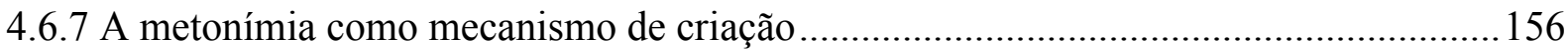

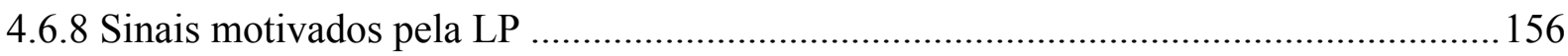

4.6.9 Criação de sinais das profissões ou referente à pessoa............................................... 158

4.6.10 Criação não linear dos sinais-termo do Meio Ambiente em LSB ............................... 158 
4.6.11 Restrições fonológicas: condições de simetria e dominância e mudança da mão

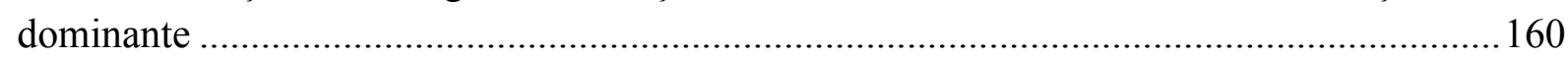

4.7 Procedimentos para padronização e edição das filmagens ........................................163

4.8 Síntese do capítulo .......................................................................................................165

CAPÍTULO 5: O MODELO DO GLOSSÁRIO ILUSTRADO SEMIBILÍNGUE ................ 166

5.1 Introdução ....................................................................................................................................166

5.2 As idiossincrasias linguísticas dos surdos e suas implicações no glossário..................166

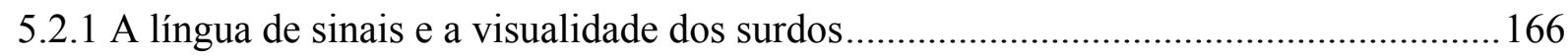

5.2.2 Português como L2 para surdos.......................................................................... 175

5.3 Descrição fonológica dos sinais-termo para a busca pela LSB..................................176

$5.4 \mathrm{O}$ suporte digital para 0 registro dos dados e a divulgação ......................................182

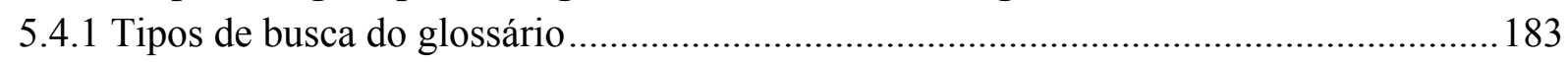

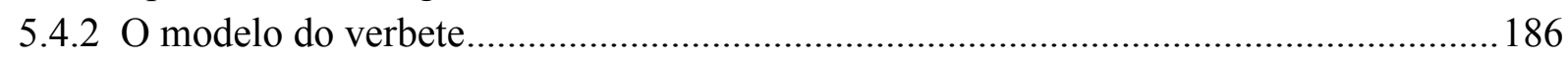

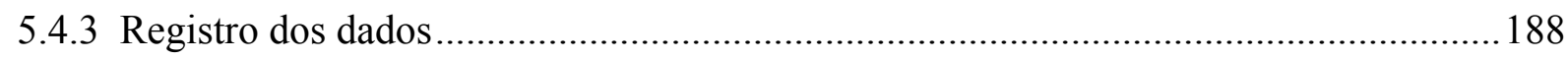

5.5 Como usar o glossário .........................................................................................192

5.6 Síntese do capítulo ..........................................................................................196

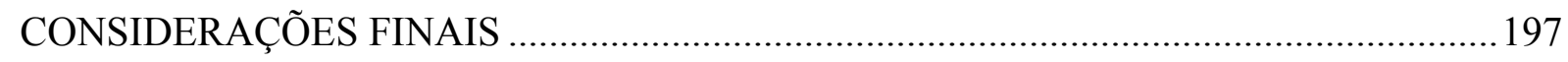

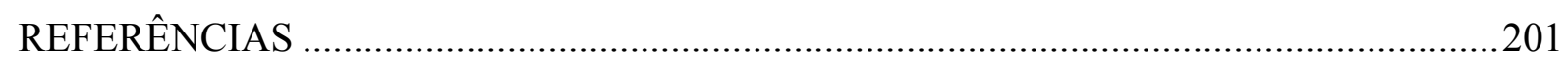

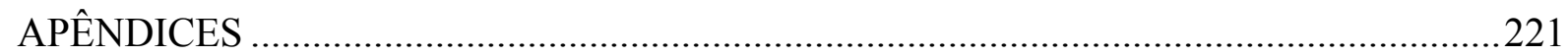

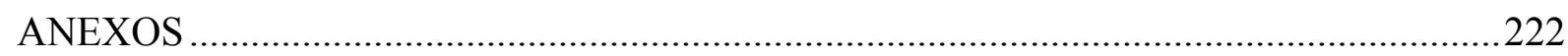




\section{INTRODUÇÃO}

Esta pesquisa se insere na área de concentração Teoria e Análise Linguística, na linha de pesquisa Léxico e Terminologia, desenvolvida no Centro de Estudos Lexicais e Terminológicos (Centro Lexterm) e no Laboratório de Língua de Sinais Brasileira (LabLibras), da Universidade de Brasília (UnB). O objeto de estudo é a terminologia do Meio Ambiente na Língua de Sinais Brasileira (LSB), assim como a criação e a validação de novas unidades terminológicas nesta língua. Contudo, o tema da tese a ser defendida é uma proposta de glossário ilustrado semibilíngue online, a fim de registrar essa terminologia do Meio Ambiente da LSB. A obra terminográfica é idealizada para estudantes surdos dos anos finais do Ensino Fundamental $-6^{\circ}$ ao $9^{\circ}$ ano.

A pergunta que guia nossa proposta é: Que características da macro e da microestrutura de uma obra lexicográfica semibilíngue contribuem para atender às especificidades dos surdos?

Para criação da obra terminográfica, produto de nossa tese, estabelecemos alguns objetivos específicos que são etapas para a construção da nossa proposta de glossário: (i) identificar o vocabulário do Meio Ambiente existente na LSB; (ii) criar e validar termos do Meio Ambiente para LSB; (iii) analisar os mecanismos de criação de sinais da LSB; (iv) reformular e uniformizar definições dos termos do Meio Ambiente em LP extraídas de diversos materiais lexicográficos e adaptar a linguagem para um português mais acessível aos surdos e (v) criar o desenho do glossário para ser programado em mídia digital.

Para tanto, tomamos como aporte teórico as áreas do Léxico, Lexicologia, Terminologia, Lexicografia e Terminografia, que servem de fundamentação teórica e prática para criação terminológica e para o fazer lexicográfico, assim como encontramos suporte teórico na Política Linguística.

Como hipótese de tese, elaboramos um glossário com base nos pressupostos da Terminologia, da Lexicografia e da Terminografia. O nosso glossário serve para o públicoalvo mencionado porque, respeita as idiossincrasias linguísticas dos surdos ao tratar a Língua Portuguesa como segunda língua e por reconhecer a importância de se ter terminologia em Língua de Sinais Brasileira, primeira língua dos surdos, como um recurso essencial ao ensino e a apreensão de conhecimentos no âmbito escolar. O glossário aproveita a habilidade de percepção de informações visuais dos surdos, com a presença de ilustrações dos termos do Meio Ambiente. As ilustrações têm a função de auxiliar na compreensão de conceitos da 
mencionada área. As imagens são revisadas por especialistas das Ciências Biológicas e por um surdo especialista.

O glossário também apresenta três mecanismos de busca de informação, pela Língua Portuguesa, pela Língua de Sinais Brasileira e por ilustrações.

Quanto ao conteúdo em Língua de Sinais (LS), os sinais são criados e validados por surdos que têm a Língua de Sinais Brasileira como primeira língua. Esses termos em LSB são criados com base nos princípios para a formação de termos da ISO 704:2000, documento internacional de normalização do trabalho terminológico.

Outra vantagem do glossário é que as definições em Língua Portuguesa não são apenas compilações de obras existentes, como a grande maioria das obras lexicográficas e terminográficas. Em nossa proposta, as definições são reformuladas levando-se em conta as orientações lexicográficas e as adequações da linguagem para um português mais acessível aos surdos e à faixa etária. Vale ressaltar que o glossário vai ao encontro da política de educação bilíngue que tem sido defendida por surdos e militantes dos movimentos surdos no Brasil. De acordo com a política educacional, as escolas devem oferecer aos alunos os conteúdos nas duas línguas e não apenas traduções da Língua Portuguesa para Língua de Sinais Brasileira.

O glossário é gratuito, encontra-se disponível na internet e é uma proposta de aplicação das orientações lexicográficas para superar o legado de criação de obras lexicográficas das línguas de sinais feitas por não profissionais, como bem mencionou Zwitserlood (2010, p. 445).

Partimos de uma perspectiva da política linguística de planejamento de corpus da LSB, principalmente no que diz respeito à necessidade de se criar terminologias para os âmbitos acadêmicos e escolares. Isto se faz necessário, pois a LSB mudou o seu status linguístico ao ser reconhecida legalmente com a Lei n 10.436 de 2002. A LSB é a língua da comunidade Surda no Brasil cujo ensino tornou-se obrigatório em vários cursos superiores, também é uma língua usada na escola, seja por professores surdos e ouvintes, seja por intermédio de intérpretes da LSB. Em síntese, é uma língua que não apenas está em associações de surdos e igrejas, mas também nas escolas e, por isso, a necessidade de seu uso ter-se ampliado.

Entendemos que nossa pesquisa é mais um passo na linguística das línguas de sinais especialmente nos estudos lexicológicos, terminológicos, lexicográficos e terminográficos da LSB. Acima de tudo, porém, é uma ferramenta de inclusão social do surdo por meio do acesso 
às informações em sua língua de aquisição natural. Apresentamos, a seguir, os cinco capítulos que compõem esta tese.

No capítulo 1, apresentamos estudos sobre a criação de sinais, os elementos constitutivos dos sinais e os tipos de sinais. Nesse capítulo, tratamos também de fenômenos relacionados à criação de sinais como a iconicidade, a metáfora, a metonímia, os classificadores, a categorização e o protótipo. Além disso, apresentamos os mecanismos de composição, derivação, extensão lexical, flexão e empréstimos nas Línguas de Sinais, bem como mostramos as restrições para criação de sinais. Esse capítulo é fundamental para tese, uma vez que discorre sobre os mecanismos de criação de sinais que servem de base para a análise dos sinais do Meio Ambiente mostrada no capítulo 4.

No capítulo 2, expomos as dificuldades para se criar uma obra lexicográfica para uma língua de sinais e apresentamos os estudos terminológicos na relação com a Política Linguística da LSB. Outrossim, mostramos obras terminológicas e lexicográficas de diversas línguas de sinais, tratamos de ilustração em dicionários de línguas orais e de língua de sinais, apresentamos também as características da lexicografia das línguas de sinais impressa e eletrônica e discutimos a definição com foco no consulente surdo.

No capítulo 3, apresentamos as discussões acerca dos procedimentos metodológicos. Nesse capítulo, apresentamos o público-alvo e suas especificidades. Ademais, discorremos sobre os procedimentos metodológicos da obra, desde a seleção dos termos que compõem o glossário até o registro dos dados no suporte digital e divulgação da obra. Também apresentamos o método de reformulação e uniformização do texto definitório da obra terminográfica.

No capítulo 4, apresentamos as pesquisas realizadas com o intuito de identificar os sinais da área do Meio Ambiente existentes na LSB e mostramos os critérios para a permanência ou não dos sinais existentes como termos desta área e detalhamos as sessões de criação e de validação dos sinais-termo. Após essas etapas, apresentamos os sinais do glossário. Por fim, seguimos com uma análise dos mecanismos de criação dos sinais oriundos das sessões de criação e de validação.

Finalmente, no capítulo 5, apresentamos o modelo do glossário, a constituição da macro e da microestrutura do glossário e a plataforma na internet onde estão registrados os termos do Meio Ambiente em Língua de Sinais Brasileira e em Língua Portuguesa.

Após a exposição dos cinco capítulos, apresentamos as considerações finais e as referências. Os apêndices e os anexos da tese encontram-se organizados em um DVD (sinaistermo do Meio Ambiente - Apêndice D) e um CD-ROM (Apêndice A - Termos retirados do 
jornal Folha de São Paulo, Apêndice B - Fichas lexicográficas como banco de dados, Apêndice C - Termos do Meio Ambiente organizados em campos temáticos, Apêndice E Descrição fonológica de 50 sinais-termo, Apêndice F - Fichas de preenchimento do glossário, Anexo A - Sistema de Transcrição de Felipe e Anexo B - Verbetes retirados das obras da LSB). Chamamos atenção ao fato de que a proposta de glossário está disponível em http://glossariolibrasportugues.com.br. A seguir, os capítulos que compõem a tese são expostos. 


\section{CAPÍTULO 1: CRIAÇÃO DE SINAIS}

\subsection{A estrutura e os tipos de sinais}

Neste capítulo, apresentamos o suporte teórico que dá sustentação à criação de sinais nas línguas de sinais (LS). Versamos sobre os fenômenos presentes na criação de sinais como a iconicidade, a metáfora, a metonímia, os classificadores, a categorização, o protótipo, a composição, a derivação, a extensão lexical, a flexão e as restrições na criação de sinais. Para tanto, antes, damos um conceito de sinal, apresentamos a estrutura interna do sinal, os tipos de sinais existentes - manuais, não manuais e multicanais - e distinguimos sinal de sinal-termo.

O sinal é um item lexical usado no léxico comum das línguas de sinais e, na literatura das LS, tem sido considerado como correspondente à palavra de uma língua oral. Quanto à estrutura interna, os sinais podem ser desmembrados em cinco parâmetros, a saber, Configuração de mão (CM), Ponto de articulação (PA), Movimento (M), Orientação da Palma (Or) e Expressões não manuais (ENM). A seguir, apresentamos cada um dos parâmetros mencionados.

As CMs são formatos adquiridos pelas mãos na produção dos sinais, que podem ser realizados com uma ou duas mãos. Esse parâmetro tem grande importância na formação de classificadores e pode guardar informações semânticas essenciais na criação de uma nova unidade lexical e terminológica. Sobre esse parâmetro, Ferreira (2010, p. 102) esclarece que “Certas CMs são usadas em línguas de sinais para representar forma e tamanho dos referentes, assim como características dos movimentos dos seres em um evento". No capítulo 5 desta tese, apresentamos as $75 \mathrm{CMs}$ da LSB sistematizadas por Faria-Nascimento (2009) e que constam da proposta de nosso glossário.

O PA é o local onde ocorre a produção dos sinais, que pode estar localizado próximo ou em contato com alguma(s) parte(s) do corpo. Não existe nenhum sinal sem ponto de articulação, como constata Aguiar (2013), entretanto, pode haver sinais sem configuração de mão, consequentemente, sem orientação da palma. É válido dizer que são raros os sinais nessa condição. Também podem existir sinais sem movimento e sem expressões não manuais. $\mathrm{Na}$ criação de sinais, o PA pode, inclusive, ser um indicador de categoria e ser motivado por metáforas orientacionais para a construção de novos sinais. A metáfora é tratada na subseção (1.2.1.1). A sistematização dos PAs desta tese segue a proposta criada por Barros (2015) para 
o sistema de escrita ELiS ${ }^{1}$, desenvolvido pela pesquisadora, composto por 35 PAs na LSB e que é apresentada no capítulo 5.

Os movimentos (M) são de diversos tipos com direções, intensidade e frequência variadas e mais de um tipo de movimento pode ser realizado simultaneamente na produção do sinal. Barros (2015) sistematiza os movimentos em uma lista composta por 44 tipos de movimentos, que também são apresentados no capítulo 5. Nessa lista, Barros considera para a sistematização algumas ENM como movimentos - servem de exemplo girar o tronco e vibrar os lábios.

A orientação da palma (Or) é a disposição da palma da mão, que pode ser para cima, para baixo, para frente, para trás, para contralateral (para medial) ou para ipsilateral (para lateral). Faria-Nascimento (2013, p. 85) lembra que a Or em LSB pode carregar significados culturalmente partilhados que influenciam na criação de novos sinais, como a Or para cima que agrega o significado de bom, positivo e de aceitação e a Or para baixo que nos remete a ruim, negativo e de rejeição.

Por último, apresentamos as Expressões Não Manuais (ENM), que são expressões faciais e corporais. Quadros, Pizzio e Rezende (2008, p. 3) classificam as ENM em dois grandes grupos, que são as expressões afetivas - usadas para expressar sentimentos de alegria, tristeza, raiva, surpresa, entre outros - e as expressões gramaticais - que podem interferir na LSB tanto no nível morfológico quanto no nível sintático. As ENM no nível da morfologia podem ser encontradas com a função de marcar o grau, diminutivo e aumentativo, e o grau de intensidade que vai em um continuum de menos intenso ao mais intenso. Ao nível sintático, as ENM podem indicar se a sentença é negativa, interrogativa, afirmativa, condicionais, relativas, construções em tópicos e construções em foco. Outra função das ENM em LSB é que podem diferenciar itens lexicais nesta língua, como, por exemplo, os sinais LARANJA e LIMÃO do dialeto de Goiânia que se diferenciam apenas por esse parâmetro.

Johnston e Schembri (2007, p. 83) apresentam a divisão de Brennan (1992) que classifica os sinais em três tipos: sinais manuais, sinais não manuais e sinais multicanais. Os sinais manuais são sinais realizados apenas com as mãos. Por outro lado, os sinais não manuais são realizados sem as mãos, isto significa dizer que são sinais sem CM e sem Or. Há, porém, os sinais multicanais que são realizados pelas mãos e por outras partes do corpo, conforme esclarecem Johnston e Schembri (2007, p. 84).

\footnotetext{
${ }^{1}$ ELiS - Escrita das Línguas de Sinais.

${ }^{2}$ Disponível em http://www.centrolexterm.com.br, acesso em 17 de agosto de 2015.
} 
Os sinais manuais, conforme Battison (2003, p.19), podem ainda ser classificados em seis tipos, são eles: o tipo 0 , tipo $\mathrm{X}$, tipo 1, tipo 2, tipo 3 e o tipo C. O sinal do tipo 0 é realizado com uma mão no espaço livre e sem contato com o corpo. Já o sinal do tipo X é realizado com uma mão que entra em contato com qualquer lugar do corpo, exceto a outra mão. O sinal do tipo 1 é executado com as duas mãos, ambas ativas, que realizam ações idênticas, sendo que as mãos podem ou não tocar alguma parte do corpo, inclusive a outra mão. Esses sinais podem ter movimentos simultâneos e alternados. $\mathrm{O}$ sinal de tipo 2 é articulado com as duas mãos, uma mão é ativa e outra é passiva, mas ambas possuem a mesma configuração de mão. O sinal tipo 3 também é executado com as duas mãos, uma ativa e a outra passiva, contudo as mãos têm diferentes formatos. Finalmente, o sinal do tipo C é a combinação de dois ou mais tipos desses apresentados.

Nesse estudo, cabe esclarecer a diferença entre o sinal e o sinal-termo. Este último é definido por Faulstich $(2012)^{2}$ como:

1. Termo da Língua de Sinais Brasileira que representa conceitos com características de linguagem especializada, próprias de classe de objetos, de relações ou entidades. 2. Termo criado para, na Língua de Sinais Brasileira, denotar conceitos contidos nas palavras simples, compostas, símbolos ou fórmulas, usadas nas áreas especializadas do conhecimento e do saber. 3. Termo adaptado do português para representar conceitos por meio de palavras simples, compostas, símbolos ou fórmulas, usados nas áreas especializadas do conhecimento da Língua de Sinais Brasileira.

Acrescentamos a definição de Faulstich que sinal-termo é, também, termo emprestado de outras línguas de sinais com ou sem adaptação fonológica e morfológica da língua receptora.

Nessa definição de Faulstich, a diferença entre o sinal-termo e o sinal do léxico comum fica evidente por ser o primeiro, uma unidade terminológica de uma área técnica ou científica, portanto de uso específico e com sentido especializado da área de conhecimento a que faz parte. Por outro lado, o sinal, unidade lexical comum, tem um uso mais recorrente na sinalização do cotidiano.

Os estudos sobre criação de terminologias das línguas de sinais ainda são incipientes e para compreendermos a criação dos sinais-termo é preciso estudar a criação de sinais de forma mais ampla. Convêm lembrar que as regras de criação de palavras são as mesmas para

\footnotetext{
${ }^{2}$ Disponível em http://www.centrolexterm.com.br, acesso em 17 de agosto de 2015.
} 
criação de termos de uma determinada língua oral, como explica Lara (1999, p. 53), quando afirma que as regras para constituição estrutural do termo são as mesmas usadas para constituição do léxico comum, não sendo, portanto, muito diferentes dos mecanismos neológicos do léxico especializado. Nessa mesma linha de pensamento, Biderman (2001, p. 158) esclarece que os termos-científicos são gerados com base na lógica da língua em questão, de acordo com os padrões lexicais e gramaticais da(s) língua(s) envolvida(s). A autora ainda acrescenta que "o vocabulário técnico-científico deve modelar-se pelos padrões existentes no sistema linguístico como meio de abordagem aproximativa desse mesmo conhecimento" (BIDERMAN, 2001, p. 160).

Assim como o léxico comum, o termo pode ser criado por processo de formação de palavras como a "derivação, composição, truncação, transferência semântica, formação sintagmática e por siglas, empréstimos entre outros recursos das línguas” (ALVES, 1998, p. 104). Dessa mesma forma, compreendemos que a criação de sinais-termo na LSB segue as regras e mecanismos dos sinais de uso quotidiano da língua.

A criação de novos itens lexicais ou terminológicos não é aleatória, a maioria das palavras é motivada por estruturas existentes na língua, sendo a criação ex nihilo ${ }^{3}$ pouco produtiva. Sobre esse tema, Delbecque (2006, p. 33) lembra que novas palavras se constroem, em geral, a partir de formas linguísticas já existentes e, por isso, tornam-se significativas aos nossos olhos.

Delbecque (2006, p. 44) acrescenta ainda que a maior parte das formas linguísticas complexas é transparente e motivada. O que Delbecque entende por transparente é a interpretação que se pode fazer dos itens lexicais novos a partir da estrutura da palavra. Esse entendimento é compartilhado por Correia $(2009$, p. 78) que define palavras transparentes como palavras "cujo significado se pode inferir a partir da sua estrutura".

As palavras transparentes estão intimamente ligadas à criatividade lexical. Essa criatividade é entendida por Correia e Almeida (2012, p.19) “como a capacidade que o falante possui para alargar o sistema linguístico, de forma consciente, por meio de princípios de abstração e comparação imprevisíveis, mas claramente motivados". Os itens lexicais são em sua maioria motivados, principalmente as palavras compostas e as derivadas. Sobre isso, Delbecque (2006, p. 33) nos orienta a "olhar de forma atenta para as palavras complexas ou os novos sentidos conferidos às palavras existentes" e perceberemos que quase todas são motivadas.

\footnotetext{
${ }^{3}$ Correia e Almeida (2012, p. 34) explicam que ex nihilo é a invenção de novas formas lexicais a partir do nada, sem nenhum tipo de motivação. Servem de exemplo as palavras gás e kodak.
} 
A motivação na constituição das línguas de sinais, por muito tempo, foi argumento para desconsiderá-las enquanto línguas. Essa motivação existe, em grande parte, devido à presença da iconicidade, contudo, as línguas orais também são constituídas de iconicidade - é verdade que em menor grau. Isso se deve, principalmente, à modalidade de língua. A motivação visual nas LS ocorre em larga escala já que se trata de uma língua de modalidade espacial e visual. Por causa das características idiossincráticas das línguas de sinais, há uma forte motivação visual nos sistemas das LS e essa característica é evidenciada nos estudos sobre criação de sinais apresentados nesse capítulo.

Para compreender como os sinais-termo são criados, antes é preciso identificar os elementos constitutivos dos sinais, os mecanismos de criação e outros fenômenos presentes na criação dos sinais, posto que, segundo Barbosa (1981, p. 174), “a criação é o resultado da combinatória de elementos mais simples existentes na língua. Desse modo, a criação consiste essencialmente no modo de relação entre esses elementos". Sendo assim, versamos um pouco mais sobre a estrutura que compõe o sinal, tratamos de outros fenômenos e mecanismos presentes na criação de sinais.

A respeito das estruturas subjacentes que configuram o léxico da LSB, FariaNascimento e Correia (2011, p. 27) mencionam o conceito de fundo lexical segundo Miller (1991) e Usón (1999), que o compreendem como a "base de constituintes e de estruturas linguísticas internamente organizadas e disponíveis para a construção lexical de uma língua”. Esses constituintes se combinam "de forma a aceitarem ou a rejeitarem a proposição de um vocábulo novo, um neologismo" (FARIA-NASCIMENTO, 2009, p. 110).

A partir das pesquisas de Faria-Nascimento (2009) e Faria-Nascimento e Correia (2011), sistematizamos os elementos que foram considerados como constitutivos do fundo lexical da LSB. Esses recursos estão disponíveis na língua para produzir infinitas construções, são eles: os parâmetros, já apresentados no início do capítulo, os classificadores, os protótipos, os ícones linguísticos (atributos, metonímia e metáforas), os morfemas-base, os empréstimos de outras LS e da LP. Apresentamos nesta seção os morfemas-base e os demais elementos são contemplados no decorrer deste capítulo.

Faria-Nascimento (2009) apresenta um conceito para compreender a inovação lexical na LSB, o de morfema-base. Para ela, os morfemas-base são "constituintes de unidades lexicais sinalizadas com o estatuto morfológico de radical, sobre os quais é possível construir uma infinidade de termos do mesmo campo semântico" (FARIA-NASCIMENTO, 2013, p. 96). Dito de outro modo, esses morfemas-base são constituídos de alguns sinais, ou parte de 
sinais, que têm a função de base para a criação de diversas palavras e têm demonstrado ser elementos constituintes produtivos na construção de sinais nas áreas de especialidades.

A pesquisadora apresenta, como exemplo, o sinal PALAVRA que passa a funcionar como morfema-base. Essa base é composta pelos parâmetros $\mathrm{CM}+\mathrm{Or}+\mathrm{PA}$, do mesmo morfema-base são formados os sinais MORFOLOGIA, DERIVAÇÃO, COMPOSIÇÃO, FLEXÃO, entre outros.

É válido frisar que, nesta pesquisa, compreendemos formação, construção e criação de palavras como sinônimos. Sabemos que alguns estudiosos do assunto fazem a distinção desses conceitos, todavia não é do nosso escopo tratar dessas distinções conceituais.

\subsection{Mecanismos de criação de sinais}

Nesta seção, apresentamos pesquisas sobre os mecanismos de criação de sinais. Para tal, abordamos os temas iconicidade, metáforas, metonímias, classificadores, categorização, protótipos, composição, derivação, extensão lexical, flexão e empréstimos nas LS.

\subsubsection{Iconicidade}

As línguas de sinais, por serem visuais, depreendem muitas características visuais do mundo em sua lógica de funcionamento, o que dá um caráter icônico à língua. Para exemplificar, pensemos no verbo "dormir" nas diversas línguas de sinais. As experiências corpóreas influenciam nas escolhas dos parâmetros deste item lexical. Se observamos o sinal de dormir nas mais diferentes línguas de sinais, provavelmente, encontraremos o movimento de fechar as mãos ou os dedos, ou mesmo fechar os olhos, ou ambos: mãos e olhos. Também podem representar a ação de encostar a cabeça para o lado como se estivesse encostado a um travesseiro ou nas mãos para dormir e, além disso, há uma probabilidade grande de serem realizados perto dos olhos.

Para Neves (1997, p. 103), “a iconicidade é um princípio pelo qual se considera que existe uma relação não-arbitrária entre forma e função, ou entre código e mensagem na linguagem humana". Nessa perspectiva, a iconicidade muitas vezes é compreendida como em oposição à arbitrariedade. Contudo, Wilcox (2004, p.140-141) tem um entendimento diferente, porque para ele, a iconicidade e a arbitrariedade são características que podem se manifestar simultaneamente na língua. 
Como já mencionamos, uma grande parte dos compostos e derivados é motivada e nas LS essas relações são mais aparentes, contudo, como bem lembrou Boyes-Braem (1986 apud Brennan, 1990, p. 13), para se pensar em iconidade é preciso levar em conta quem perceberá determinada relação como icônica na língua. Isso porque muito da iconicidade existente nas línguas de sinais não é facilmente identificada por quem não conhece a língua.

Taub (2004, p. 42, tradução nossa), assim como Wilcox (1998), entende que "a iconicidade é uma relação não entre as palavras e o mundo, mas entre as nossas concepções mentais da forma de um item linguístico e seu significado; devido a isso, Wilcox usou o termo iconicidade cognitiva",4.

Faulstich (2007, p. 155), por sua vez, com base no filósofo Peirce, postula a iconicidade em LSB como um fenômeno que não está apenas ligado à forma, e esclarece em seu postulado que "a iconicidade em Libras é um fenômeno de cognição, posto que uma palavra em Libras, sob a perspectiva do "objeto dinâmico", é um signo complexo, e a significação é um processo que se dá em cadeia de interpretantes de diferentes tipos." Convém esclarecer que, o signo ${ }^{5}$ para Peirce é tripartite composto por fundamento do representâmen, objeto e interpretante.

À luz do pensamento de Faulstich (2007), Faria-Nascimento e Correia (2011, p. 31) definem os ícones linguísticos como elementos "motivados pela forma ou atributos dos referentes, bem como por metonímias e metáforas que se incorporam à cognição a partir do momento de sua constituição". Faria-Nascimento e Correia classificam os ícones linguísticos em atributos, metáforas e metonímias.

Faria-Nascimento e Correia (2011, p. 31) explicam que os atributos são características dos referentes que podem ser empregadas como ícones na constituição dos sinais. Esses atributos podem representar uma ação, forma, tamanho, consistência, espessura, tonalidade, odor, paladar, entre outros. Os atributos podem ser incorporados a alguns tipos de classificadores, conforme esclarece Faria-Nascimento (2009, p. 119). Os classificadores são tratados no subseção (1.2.1.2).

\footnotetext{
${ }^{4}$ Texto original: "...iconicity is a relationship not between words and the world but between our mental conceptions of a linguistic item's form and its meaning; because of this, he used the term cognitive iconicity." (TAUB, 2004, p. 42).

${ }^{5} \mathrm{O}$ signo de Pierce é também denominado representâmen. Segundo o autor, um signo "é aquilo que, sob certo aspecto ou modo, representa algo para alguém" (PIERCE, 2010, p. 46).
} 


\subsubsection{Mecanismos semânticos: Metáforas e Metonímias}

Lakoff e Johnson (2012) ${ }^{6}$ trazem um novo olhar sobre o uso de metáforas nas línguas. Essas deixam de ser apenas uma figura de linguagem para ser um mecanismo que permeia a linguagem e os pensamentos humanos, pois como afirmam esses autores "os processos do pensamento humano são em grande medida metafóricos" (LAKOFF e JOHNSON, 2012, p. 42) e que na vida cotidiana, não somente a linguagem, mas os pensamentos e ações estão impregnadas de metáforas. Para Lakoff e Johnson (2012, p. 41), “a essência da metáfora é entender e experimentar uma coisa em termos de outra”. Serve de exemplo a metáfora “discussão é uma guerra" que, por meio de expressões do cotidiano, podem refletir esse pensamento metafórico, como em "Atacou todos os pontos fracos do meu argumento" ou "Ele nunca venceu uma discussão" (LAKOFF e JOHNSON, 2012, p. 40). Essas metáforas fazem referência às situações de guerra com os verbos atacar e vencer.

As metáforas também estão presentes nas LS. Taub (2000 apud Valli et al. 2011, p. 159), pesquisadora da ASL, explica que há uma forte relação entre metáfora e iconicidade. Sobre essa relação Taub esclarece que:

A metáfora é o uso de um domínio da experiência, o concreto, para descrever ou raciocinar sobre o domínio abstrato, e o sistema icônico de representação em línguas de sinais tem movimentos, locações e configurações de mão que podem ser utilizados para a descrição metafórica de situações abstratas (não-físicas). (TAUB, 2000 apud VALLI et al., 2011, p. 159 , tradução nossa). ${ }^{7}$

Taub reforça que a metáfora em língua de sinais envolve o double mapping 'mapeamento duplo', isto é, “há uma relação entre o concreto e o abstrato, e uma relação entre a imagem concreta escolhida para o representar o abstrato e as formas (configuração de mão,

\footnotetext{
6 Livro originalmente publicado em 1980 cujo título original da obra é Metaphors We Live By.

${ }^{7}$ Texto original: "Metaphor is the use of one domain of experience, the concrete one, to describe or reason about the abstract domain, and the iconic system of depiction in sign languages has movements, locations, and handshapes that can be used for the metaphorical description of abstract (nonphysical) situations." (TAUB, 2000 apud VALLI et al., 2011, p. 159).
} 
locação, movimento, orientação palma, sinais não manuais) ${ }^{8 "}$ (TAUB, 2000 apud VALLI et al., 2011, p. 159, tradução nossa).

Para explicar mais claramente o double mapping, reproduzimos o quadro de Taub (2001, p. 119) que analisa a metáfora "intimidade é proximidade" presente na ASL (quadro 1). Segundo Taub (2001, p. 119), essa metáfora motiva parcialmente sinais como LOVE 'amor', FRIEND 'amigo', CLOSE-FRIENDS 'amigos íntimos', MARRY 'casar' e DIVORCE 'divórcio', por exemplo. Na figura 1, os articuladores do sinal CLOSE-FRIENDS encontram-se bem próximos um do outro, já no sinal DIVORCE, os articulares se afastam.

Quadro 1 - Mapeamento duplo para "intimidade é proximidade" mapeamento icônico mapeamento metafórico

\begin{tabular}{|l|l|l|}
\hline \multicolumn{1}{|c|}{ articuladores } & \multicolumn{1}{c|}{ fonte } & \multicolumn{1}{c|}{ alvo } \\
\hline $\begin{array}{l}\text { dois articuladores (ex: mãos, } \\
\text { dedos, corpo) }\end{array}$ & duas entidades físicas & $\begin{array}{l}\text { dois referentes (ao menos um } \\
\text { é animado) }\end{array}$ \\
\hline $\begin{array}{l}\text { grau de proximidade dos } \\
\text { articuladores }\end{array}$ & $\begin{array}{l}\text { grau de proximidade das } \\
\text { entidades }\end{array}$ & $\begin{array}{l}\text { grau de intimidade entre os } \\
\text { referentes }\end{array}$ \\
\hline articuladores próximos & entidades próximas & $\begin{array}{l}\text { intimidade intensa entre os } \\
\text { referentes }\end{array}$ \\
\hline articuladores distantes & entidades distantes & $\begin{array}{l}\text { pouca intimidade entre os } \\
\text { referentes }\end{array}$ \\
\hline $\begin{array}{l}\text { movimento dos articuladores, } \\
\text { unem-se ou separam-se }\end{array}$ & $\begin{array}{l}\text { movimento das } \\
\text { entidades, unem-se ou ou } \\
\text { separam-se }\end{array}$ & $\begin{array}{l}\text { intimidade entre os } \\
\text { referentes se torna maior ou } \\
\text { menos }\end{array}$ \\
\hline
\end{tabular}

Fonte: Taub (2001, p. 119), adaptação e tradução nossa

Figura 1 - Sinais da ASL CLOSE-FRIENDS e DIVORCE

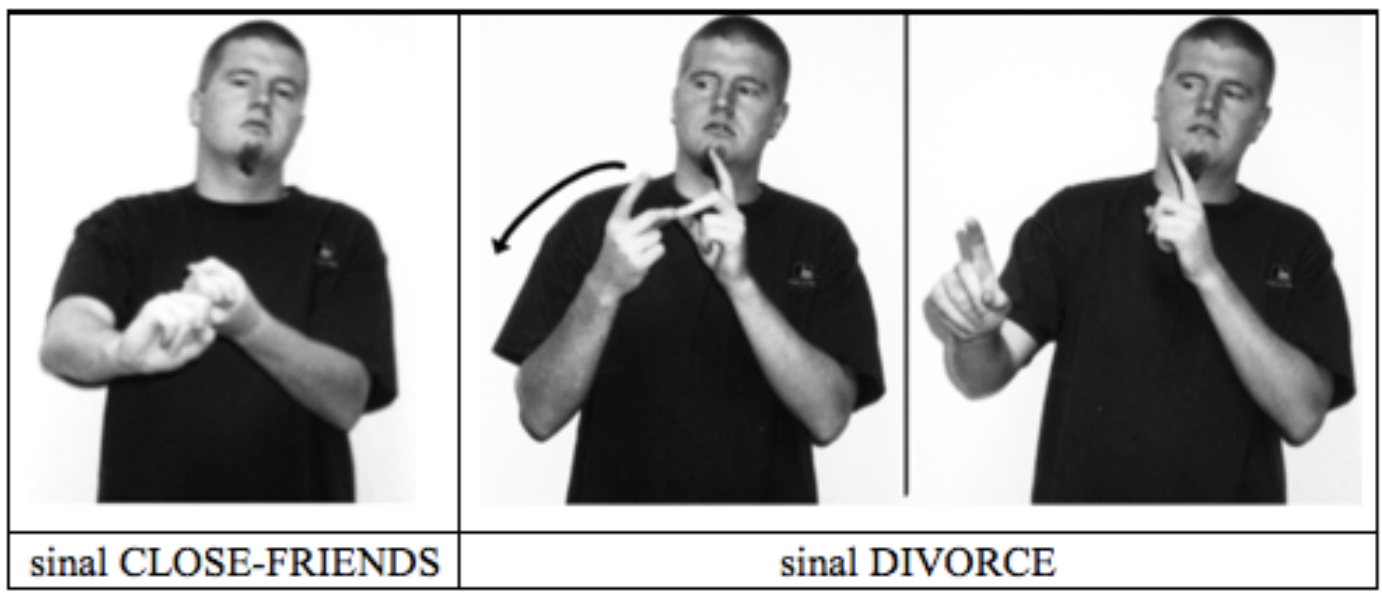

Fonte: Taub (2001, p. $120-121)$

\footnotetext{
${ }^{8}$ Texto original: "there is a relationship between the concrete and the abstract, and a relationship between the concrete image chosen to the represent the abstract and the forms (handshape, location, movement, palm orientation, nonmanual signals)".(TAUB, 2000 apud VALLI et al., 2011, p. 159)
} 
A evidência da existência da metáfora "proximidade é intimidade", segundo Taub (2001), confirma-se porque vários sinais da ASL, que se referem à intimidade e afeição, mostram a proximidade entre os articuladores e quando se referem à rejeição, à não gostar, à desaprovação há um distanciamento entre os referentes.

Benczes (2010, p. 219, tradução nossa) trata a metáfora e a metonímia como mecanismos de criação das línguas quando comenta que "a metáfora e a metonímia podem ser empregadas de forma sistemática para criar combinações do tipo substantivo-substantivo, portanto, tais construções podem ser remetidas a padrões regulares, produtivos"

As metáforas orientacionais podem ser encontradas na LSB e são produtivas na criação de sinais. Para Lakoff e Johnson (2012, p. 50) "as metáforas orientacionais dão ao conceito uma orientação espacial: por exemplo, feliz é para cima" ${ }^{\text {10 }}$. Existe uma gama de sinais que tem o PA motivado por alguma metáfora orientacional. Isso é bem perceptível nos sinais referentes aos sentimentos que se localizam perto do peito, sinais relacionados às atividades intelectuais, produzidos na cabeça, ou ainda sinais que fazem referência à alimentação e são executados perto da boca. Para exemplificar os sinais referentes aos sentimentos, citamos os itens lexicais AMOR, SAUDADE, PIEDADE, MEDO e ÓDIO que são todos realizados em um PA próximo ao peito.

A metonímia, por sua vez, para Lakoff e Johnson (2012, p.73, tradução nossa), é "uma entidade usada para se referir a uma outra que está relacionada a ela"11, isto significa dizer que há uma relação de contiguidade entre dois domínios. Para exemplificar, listamos os casos mais típicos de metonímia que são, a saber, "a pessoa pelo nome”, "o possuidor pelo objeto possuído", "o autor pelo livro", "o local pelos habitantes", "o produtor pelo produto" e "o contentor pelo conteúdo" (DELBECQUE, 2006, p. 70). As metonímias são ferramentas produtivas nas LS do mundo para criação de novos sinais. Os sinais de animais nessas línguas demonstram a produtividade desse mecanismo dentro dos sistemas linguísticos.

A Língua de Sinais Brasileira apresenta um mecanismo linguístico - que é quase sempre motivado por processos metonímicos - para nomear individualmente os animais. Servem de exemplos os sinais RINOCERONTE, BODE e PATO. Quando observamos os animais e seus respectivos sinais em LSB, facilmente identificamos a parte do animal

\footnotetext{
${ }^{9}$ Texto original: “...metaphor and metonymy can be employed in systematic ways to create noun-noun combinations, therefore, such constructions can be traced back to regular, productive patterns." (BENCZES, 2010, p. 219).

${ }^{10}$ Texto original: "Las metáforas orientacionales dan a un concepto una orientación espacial: por ejemplo Feliz es arriba". (LAKOFF e JOHNSON, 2012, p. 50).

${ }^{11}$ Texto original: "una entidad para referirnos a otra que está relacionada con ella". (LAKOFF e JOHNSON, 2012, p. 73).
} 
representada no sinal: o chifre do rinoceronte, as barbichas do bode e o bico do pato. $\mathrm{O}$ processo de representar a parte pelo todo é uma das manifestações da metonímia.

A parte pelo todo tem sido a forma mais recorrente de se criar sinais de animais na LSB. O uso de metonímias para dar nome aos animais não é uma exclusividade da LSB, diversas línguas de sinais compartilham esse mesmo fenômeno. No site http://www.spreadthesign.com/br/, podemos encontrar sinais de 25 línguas de sinais do mundo. Ao pesquisar os sinais para elefante em 19 línguas de sinais, constatamos que em todas o sinal era metonímico e representava a tromba do animal. Nessa situação, o elefante não é um caso isolado. Vários dos sinais de baleia em outras línguas de sinais apresentaram a característica desse animal de esguichar água quando surge na superfície para respirar.

É válido apresentar mais o exemplo do sinal de girafa na Língua de Sinais Francesa (LSF), figura 2, que remete ao enorme pescoço do animal. Em várias outras línguas de sinais, os itens lexicais se remetem ao pescoço desse animal, inclusive a LSB.

Figura 2 - Sinal GIRAFE 'girafa' da LSF

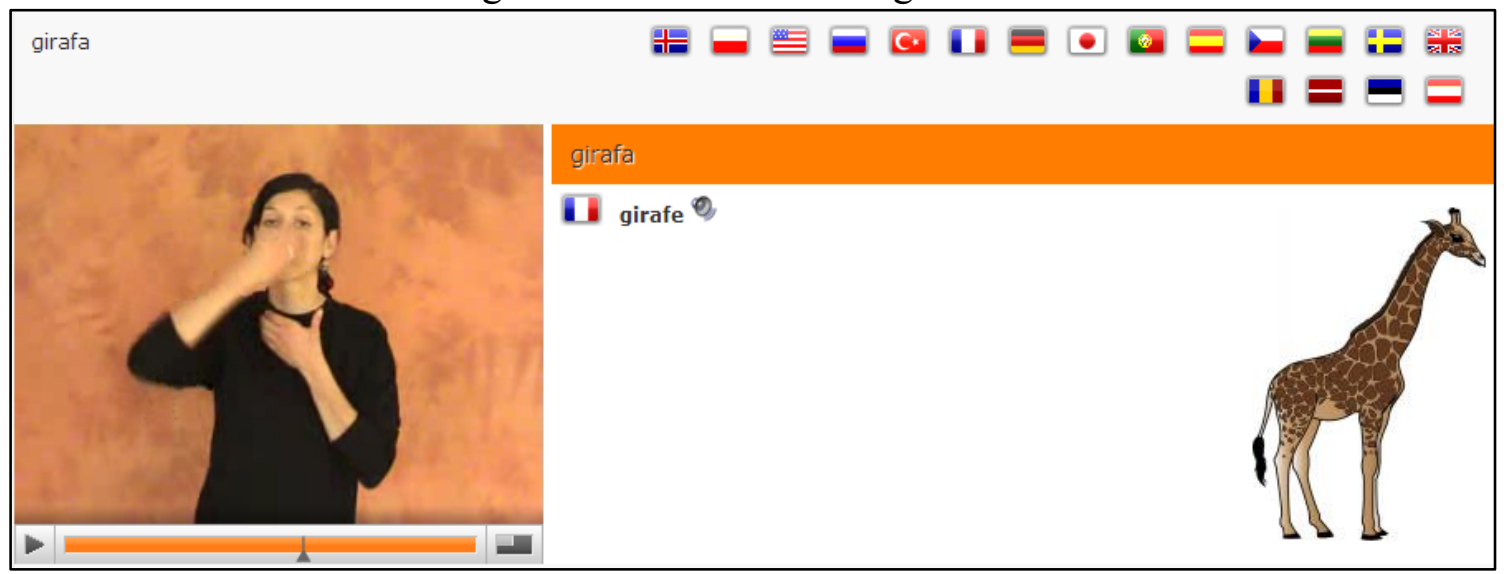

Fonte: Site Spread the sign. Disponível em: <http://www.spreadthesign.com/br/>. Acesso em: 21 jul. 2013.

Barros e Aguiar (2013) realizaram uma pesquisa sobre o uso de metonímias na criação de nomes de espécies de animais na LSB e identificaram três tipos de processos metonímicos nos sinais que são: parte pelo todo, ação pelo agente e a combinação parte pelo todo + ação pelo agente.

\subsubsection{Classificadores}

Os classificadores (CLs) são elementos essenciais nas línguas. Crystal (1985 apud Brennan, 1990, p. 38), define classificadores como: 
Morfemas cuja função é indicar a classe formal ou semântica que pertencem os itens, às vezes são chamados classificadores, por exemplo, 'ly' é um classificador de advérbio, 'ess' é um classificador de "feminilidade". A marcação dos itens lexicais como pertencentes a mesma classe semântica é uma característica importante de muitas línguas (por exemplo, o Chinês, o Vietnamita, o Hopi) e, por vezes, bases bastante inesperadas de classificação são encontradas, em termos de forma, tamanho, cor, mobilidade, animacidade, status e assim por diante. (CRYSTAL, 1985 apud BRENNAN, 1990, p. 38, tradução nossa $)^{12}$

Nas discussões que envolvem o tema CLs em LS, existem diferentes concepções que envolvem esse fenômeno. Há um livro, organizado por Emmorey, intitulado Perspectives on classifier constructions in sign languages, que discute os CLs nas LS e mostra as divergências sobre o tema, a começar pela nomeação do fenômeno que recebe denominações variadas. No Brasil, Campello (2008) sugere a denominação descrição imagética em vez de classificador. Sobre o conceito de CL, Ferreira (2010, p. 102) explica que:

Os CLs são morfemas que existem em línguas orais e línguas de sinais. Entre as primeiras, as línguas orientais são as que mais apresentam CLs. As línguas de sinais, talvez, por serem línguas espaço-visuais, fazem uso frequente de vários tipos de CLs, explorando também morfologicamente o espaço multidimensional em que se realizam os sinais.

Já para Quadros e Karnopp (2004, p. 93), os classificadores são “formas complexas em que a configuração de mão, o movimento e a locação da mão podem especificar qualidades de um referente". Ainda segundo as autoras, as funções dos classificadores são especificar o movimento e a posição de objetos e pessoas, ou descrever o tamanho e a forma de um objeto. Ademais, de acordo com as autoras, os classificadores têm uma participação produtiva na criação de novos sinais, o que vai ao encontro da afirmação de que "Os classificadores reconhecidamente desempenham um papel chave na criação de novos sinais" (BRENNAN, 1990, p. 45, tradução nossa).

\footnotetext{
${ }^{12}$ Texto original: Morphemes whose function is to indicate the formal or SEMANTIC class to which items belong are sometimes called classifiers, eg, '-ly' is an ADVERB classifier, '-ess' is a 'femininity' classifier. The marking of LEXICAL items as belonging to the same semantic class is an important feature of many languages (eg, Chinese, Vietnamese, llopi) and sometimes quite unexpected bases of classification are found, in terms of shape, size, colour, movability, animacy, status and so on." (CRYSTAL, 1985 apud BRENNAN, 1990, p. 38).

${ }^{13}$ Texto original: "Classifiers are recognised as playing a key role in the creation of new signs." (BRENNAN, 1990, p. 45).
} 
No entendimento de Quadros e Karnopp, os CLs são sinais, conceito não partilhado por Faria-Nascimento (2009, p. 117) que reconhece que os CLs são constituídos pelos mesmos componentes das unidades lexicais da LSB, mas os diferenciam. Para FariaNascimento, a principal diferença entre uma unidade lexical e um CL é que os CLs têm funções descritiva e especificadora no discurso sintático ou semântico. Além disso, os CLs têm significado complexo, pois substituem referentes e incorporam ações. A partir dessas características, Faria-Nascimento (2009, p. 116) define classificador como:

uma unidade morfêmico-lexical simples com unidade semântico sintática complexa. Em outras palavras, um tipo de morfema livre com grande informação semântica e que, por isso, representa ora um sintagma nominal, ora um sintagma verbal com alto poder de ajuste pragmático.

Faria-Nascimento (2009, p. 117) explica ainda que as CMs determinam os referentes principais a serem classificados, no entanto, acredita que a CM por si só não constitui o classificador.

Para evidenciar a influência das CMs nos CLs das LS, criamos um quadro, com base na figura apresentada por Brennan (1990, p. 62), que mostra os classificadores para humano, animal pequeno, veículo, avião e árvore. Os CLs da ASL estão apresentados na segunda coluna, os da BSL, terceira coluna, e os da LSB, quarta coluna. Esta última, acrescentada por nós.

Quadro 2 - Quadro de CLs da ASL, da BSL e da LSB adaptado de Brennan (1990, p. 62)

\begin{tabular}{|c|c|c|c|}
\hline CL para & ASL & BSL & $\mathrm{LSB}^{14}$ \\
\hline humano & & & \\
\hline animal pequeno & & & gै? \\
\hline veículo & $\int_{s}$ & हारा & \\
\hline
\end{tabular}




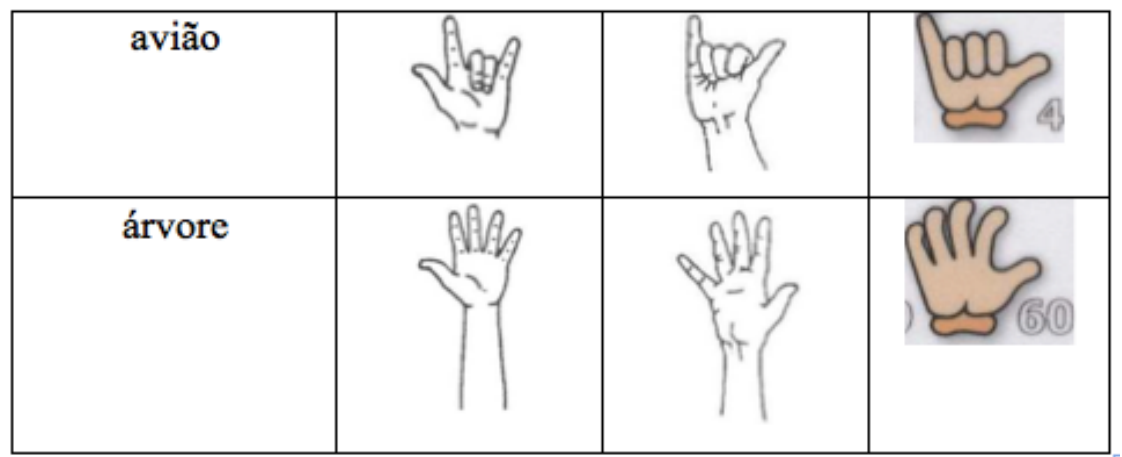

Fonte: Adaptado pela autora com base em Brennan (1990, p.62)

Pizzio et al. (2009) organizam os CLs encontrados nas LS em CLs descritivos, CLs especificadores, CL plural, CLs instrumentais e CL de corpo. Os primeiros CLs são usados para descrever forma, tamanho, textura, paladar, cheiro, sentimentos e pode-se utilizar uma ou duas mãos na produção desses CLs. Além disso, existe o CL descritivo locativo que envolve uma ação que delimita um objeto em relação ao outro. Ademais, há o CL descritivo que envolve uma ação ou posição de várias partes do corpo humano, objetos animados e inanimados.

O segundo é o CL especificador cuja função é descrever visualmente a forma, o tamanho, a textura, o paladar, o cheiro, os sentimentos, o "olhar", os "sons" do material, do corpo de pessoas e animais. Há também CLs para especificar elementos gasosos, descrever símbolos, nomes de logomarcas e números relacionados a objetos animados e inanimados (PIZZIO ET AL., 2009, s/n).

O terceiro é o CL de plural, em que a CM substitui o objeto e se repete várias vezes. Os penúltimos são os CLs instrumentais que incorporam o instrumento descrevendo a ação gerada pela ferramenta ou por quem realiza a ação. Por último, os CLs de corpo que descrevem a ação por meio de expressões corporais.

\subsubsection{Categorização e Protótipos}

Alguns estudiosos consideram que a função da linguagem é categorizar o mundo. Para Biderman (2001, p. 156), a "categorização é um mecanismo de organização mental da informação". Duque (2001, s/n) argumenta ainda que "as categorias se estruturam em torno de um centro cognitivo, seja perceptivo ou conceptual". Os protótipos e os graus de prototipicidade favorecem a organização mental dos conhecimentos e ainda, segundo Duque, “o protótipo deixa de ser causa para ser efeito" (DUQUE, 2001, s/n). 
Para Delbecque (2006, p. 38-39), o protótipo é "o membro mais representativo, o melhor da categoria". Duque (2001, s/n), com base nos estudos de Rosh, entende que "o protótipo atua como ponto de referência cognitiva para os processos de classificação dos elementos de nossa experiência".

A Língua de Sinais Brasileira tem em sua estrutura lexical várias categorias representadas por protótipos. Podemos mencionar a categoria de transportes, que elege o carro como o elemento mais prototípico; a categoria de animais é representada pelo cachorro - no dialeto sinalizado em Goiânia -, a dos insetos, pela barata e a das frutas, elege-se a maçã. Outro exemplo é a categoria de frios que utiliza o sinal QUEIJO^DIVERSOS, elegendo o queijo como o melhor exemplar da categoria. Kleiber (1995, p. 27, tradução nossa), com base nas pesquisas de Rosh, esclarece que o protótipo é "o exemplo mais adequado e até mesmo pode ser o melhor representante de uma categoria" ${ }^{\prime 4}$. Duque (2001) mostra a ruptura da teoria padrão dos protótipos e apresenta a noção de graus de prototipicidade.

$\mathrm{Na}$ versão padrão, haveria um melhor exemplar de uma determinada categoria; na versão ampliada, existem os graus de prototipicidade - esse continuum parece corresponder melhor aos fenômenos da LSB. Tomando como exemplo a categoria "animais", encontramos dois animais que a representa: o cachorro e o leão. Se apenas existisse um único protótipo, então, um dos dois animais deveria ser o verdadeiro protótipo. A versão ampliada concebe a teoria dos protótipos em níveis de prototipicidade e permite que mais de um elemento possa ocupar o lugar do protótipo. Nessa perspectiva, os elementos são mais prototípicos ou menos prototípicos e, por isso, os melhores exemplares podem concorrer para nomear a categoria, gerando a variação na denominação de um determinado agrupamento.

Faria-Nascimento (2009, p. 26-27), com base nos estudos de Rosh, Kleiber e da Língua de Sinais Americana (ASL) de Klima e Bellugi (1979), apresenta como são estruturadas as categorias nessa língua por meio dos protótipos. Na ASL, a categoria é representada por mais de um membro prototípico. Serve como exemplo o sinal da categoria mobiliário composto por três membros prototípicos da categoria $\mathrm{CHAIR}^{\wedge} \mathrm{TABLE}^{\wedge} \mathrm{BED}^{\wedge} \mathrm{ECT}$, que significa cadeira, mesa e cama formam o sinal MOBILIÁRIO em ASL. Outro exemplo nessa mesma língua é o sinal $\mathrm{RING}^{\wedge} \mathrm{BRACELET}^{\wedge} \mathrm{NECKLACE}^{\wedge} \mathrm{EARINGS}^{\wedge} \mathrm{ECT}$, que unem os sinais de anel, pulseira, gargantilha e brinco para formar a categoria bijuteria.

\footnotetext{
${ }^{14}$ Texto original: "el ejemplar más idóneo e incluso el mejor representante o caso central de una categoría." (KLEIBER, 1995, p. 27).
} 
Faria-Nascimento (2009) realizou alguns experimentos em sua pesquisa para eliciar possíveis protótipos da LSB que representassem categorias em LSB, e não houve conflito

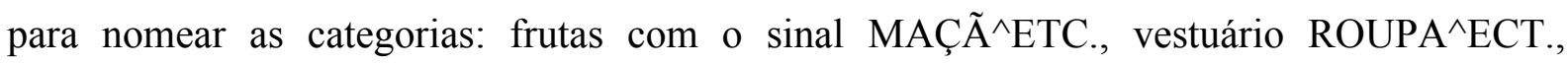
brinquedos BRINCAR ${ }^{\wedge} E C T$. e insetos $\mathrm{ANTENA}^{\wedge} \mathrm{ETC}$. Todavia, para a categoria dos felinos, duas opções surgiram, isto porque o sinal LEÃO já ocupa a posição de protótipo para nomear a categoria animal e a necessidade de preencher uma informação mais especializada motivou a criação dos sinais $\mathrm{LEÃO}^{\wedge} \mathrm{BIGODE}^{\wedge} \mathrm{ETC}$. e $\mathrm{BIGODE}^{\wedge} \mathrm{ETC}$.

\subsubsection{Composição}

A Composição, como bem mencionam Quadros e Karnopp (2004, p. 102), "é um processo de formação de palavras que utiliza estruturas sintáticas para fins lexicais", por isso, muitas vezes, surge o problema para classificar se o sinal é formado por composição ou é uma sentença na LSB.

Quadros e Karnopp (2004, p. 103-105) apresentam as regras morfológicas para sinais compostos, propostas por Liddel (1984) para a ASL, que ajudam a verificar o grau de acomodação dos sinais criados. As regras apresentadas são: do contato, da sequência única e da antecipação da mão não dominante.

A regra do contato ocorre se o sinal possui contato, seja no corpo ou na mão não dominante, a tendência é manter o contato. A regra da sequência única diz respeito aos movimentos internos e repetições que tendem a desaparecer em compostos. Por fim, a regra da antecipação da mão não dominante, refere-se ao posicionamento da mão não dominante, geralmente, antes da mão dominante.

Felipe (2006) menciona os sinais formados por processo de composição em LSB por justaposição e por aglutinação. Todavia, em seus exemplos, mostra e classifica apenas os sinais que são compostos por justaposição. Felipe (2006, p. 206) apresenta a seguinte classificação para os compostos por justaposição: de dois itens lexicais/sinais, de um classificador com um item lexical/sinal e da datilologia da palavra com um item lexical/sinal.

Para a autora, a justaposição de dois itens lexicais é a junção de dois sinais ou dois morfemas livres para formar um novo sinal. Servem de exemplos, os sinais mencionados por Felipe (2006, p. 206) CAVALO ${ }^{\wedge}$ LISTRA-PELO-CORPO (CAVALO+LISTRA-PELOCORPO = 'zebra'), MULHER^BEIJO-NA-MÃO (MULHER+BEIJO-NA-MÃO = 'mãe') e $\mathrm{CASA}^{\wedge}$ ESTUDAR (CASA+ESTUDAR = 'escola'). No caso do sinal ESCOLA, conseguimos identificar com facilidade os morfemas livres CASA e ESTUDAR. Por outro lado, os sinais 
ZEBRA e MÃE são mais difíceis de identificar os dois morfemas livres, isso porque LISTRA-PELO-CORPO e BEIJO-NA-MÃO são encontrados na língua, geralmente, junto com outro morfema livre, isto significa dizer que, em geral, só aparecem em sinais compostos e não de forma autônoma, como sinais simples.

A autora ainda afirma que a justaposição de um classificador com um item lexical é um tipo de sinal composto e ocorre quando o CL não é marcador de gênero e funciona como um clítico, servem de exemplos os sinais coisa-pequena^PERFURAR 'alfinete' e coisapequena^APLICAR-NO-BRAÇO 'agulha'. Porém, a autora não mostra exemplos de como um CL pode marcar gênero. Um outro problema para compreender os dados de Felipe, é que a revista ${ }^{15}$ na qual o artigo está disponível, não dá acesso ao link dos vídeos para conferir o significado dessas glosas. A partir das glosas, nosso posicionamento é de discordância em relação à explicação de Felipe porque, assim como Faria-Nascimento (2009), entendemos que o CL, apesar de ter as mesmas propriedades de um sinal, não é sinal e os exemplos apresentados são considerados por nós como CLs e não como sinais, sendo assim, não os compreendemos como sinais compostos.

O terceiro tipo de composição, identificado por Felipe, é a justaposição da datilologia da palavra que ocorre quando é composto por um sinal que representa a ação de substantivo mais a datilologia da palavra em Português, o exemplo mencionado é COSTURAR-COMAGULHA^A-G-U-L-L-H-A 'agulha'. Também discordamos dessa classificação de Felipe porque a datilologia pura ou transliteração pragmática, como denominou Faria-Nascimento (2009), não é, no nosso entendimento, um item lexical, apenas é um recurso momentâneo da língua e, dessa forma, o exemplo dado não pode ser considerado como composição por se tratar de um recurso efêmero. Sendo assim, o sinal juntamente com a datilologia não configura uma composição plena, tendo em vista que não é uma composição estável.

\subsubsection{Derivação}

A derivação em LS tem sido identificada em pares de nomes e verbos da ASL. Valli et al. (2011, p. 63) apresentam uma lista de nomes e verbos que se distinguem apenas pelo movimento. Esse processo de formação de palavras em ASL foi analisado primeiro por Supalla e Newport (1978).

15 Revista Educação Temática Digital, Campinas, v.7, n.2, p. 199-216. jun. 2006. Disponível em: $<$ http://ojs.fe.unicamp.br/ged/etd/article/view/1642> Acesso 31 ago. 2016. 
Na LSB, muitas vezes, o item lexical para se referir a determinados nomes e verbos é o mesmo. Contudo, Quadros e Karnopp (2004, p. 97-98) apresentam alguns sinais da LSB que podem derivar nomes de verbos pela mudança no tipo de movimento e exemplificam com os pares TELEFONAR/TELEFONE, SENTAR/CADEIRA, PERFUMAR/PERFUME, PENTEAR/PENTE, OUVIR/OUVINTE e ROUBAR/LADRÃO. Os movimentos que os diferenciam são as repetições nos nomes e o encurtamento do movimento nos verbos. Todavia, esse mecanismo de derivação não é muito comum na LSB, dessa forma, o contexto linguístico é que define se determinado sinal é nome ou verbo. Sobre esse tema, Felipe (2006) o categoriza como processo de derivação zero na LSB, já que muitos verbos denominais ou substantivos verbais são executados da mesma forma. Felipe também explica que a derivação zero pode ocorrer no par verbo de estado/adjetivo, como nos exemplos EMAGRECER/MAGRO e AMARELAR/AMAREL@.

Johnston e Schembri (2007, p.127, tradução nossa), pesquisadores da Língua de Sinais Australiana (AUSLAN), definem afixação como "processo que forma novas palavras pela combinação de afixos presos e morfemas livres"16. Segundo Johnston e Schembri (2007, p.127), o uso de afixos é considerado um processo de baixa frequência na gramática da AUSLAN. Brennan (1990, p. 137) igualmente conclui que o uso da afixação na BSL não é produtivo.

$\mathrm{Na}$ ASL, há um sufixo agentivo, que é uma marca de pessoa (figura 3), servem de exemplo os sinais WRITER 'escritor' e TEACHER 'professor' que sem a marca de pessoa significariam, respectivamente, WRITE ‘escrever' e TEACH 'ensinar'.

Figura 3 - Marca de pessoa da ASL

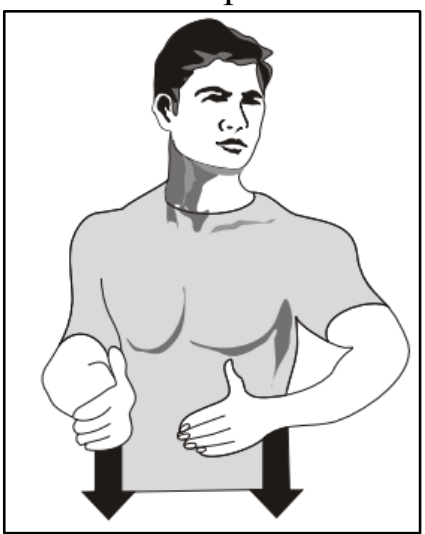

Fonte: Ilustração com base em Costello (1994, p. xv) ${ }^{17}$

\footnotetext{
${ }^{16}$ Texto original: "process that forms new words by combining bound affixes and free morphemes." (JOHNSTON e SCHEMBRI, 2007, p.127).

${ }^{17}$ As figuras 4 e 5 foram ilustradas por Sérgio Pinto com base nas ilustrações de Costello (1994, p. Xv).
} 
Figura 4 - Sinais WRITER e TEACHER

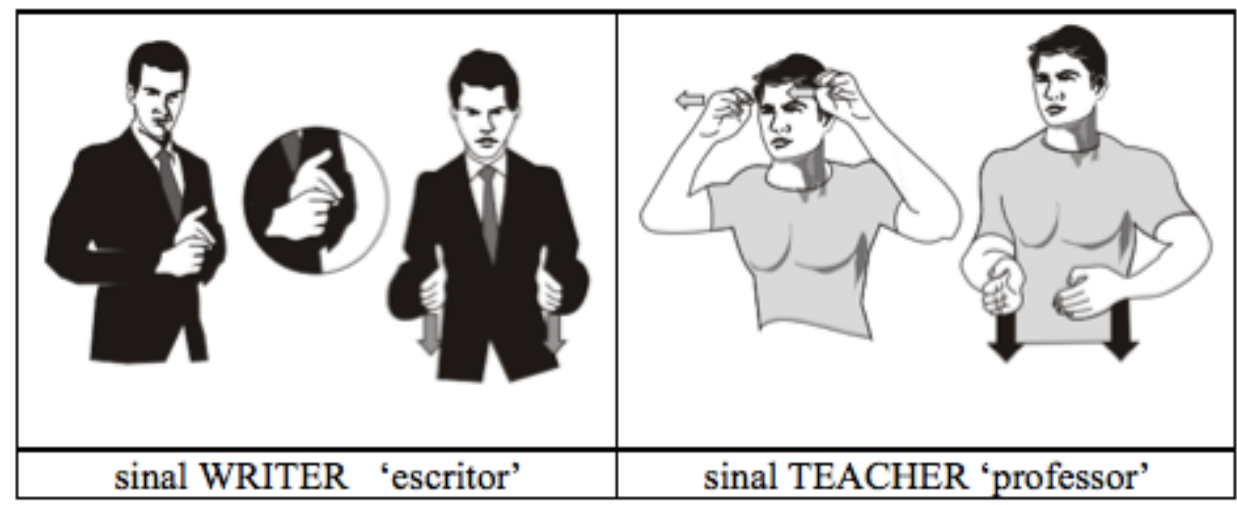

Fonte: Ilustrações com base em Costello (1994, p. xv)

\subsubsection{Extensão lexical}

A extensão lexical é um importante mecanismo para criação de novas palavras por meio da polissemia. Correia e Almeida (2012, p. 62) denominam esse mesmo mecanismo de "atribuição de novos significados a palavras já existentes" de "extensão semântica". As autoras explicam que a metáfora e a metonímia são "recursos cognitivos que facilitam a conceptualização da realidade, permitindo, portanto, apreender de forma mais eficiente estruturas conceptuais que nos são estranhas, ou pela sua abstração, ou pelo nível de conhecimento especializado que requerem".

A extensão lexical nas LS, de acordo com Brennan (1990, p. 161), parece ser um pouco diferente do que acontece nas línguas orais, embora haja este processo nas LS pode ocorrer alterações nos parâmetros. Johnston e Schembri (2007, p.124), pesquisadores da Língua de Sinais Australiana exemplificam a extensão lexical, sem modificação, nos sinais BRIDGE/SYDNEY 'ponte/Sydney’ e CHAT/AUSLAN 'conversar/AUSLAN'. A extensão lexical pode ocorrer pelo mecanismo semântico da metonímia, como é o caso do sinal SYDNEY que faz referência à ponte da Baía de Sidney, um ponto turístico da cidade da Austrália. Esse mecanismo, com modificação, é exemplificado na pesquisa de Brennan (1990, p. 162) na qual apresenta uma alteração no parâmetro locação, que permite a extensão do significado do sinal CHINESE SCRIPT 'escrita chinesa', sinal em que a locação das mãos inicia-se na altura dos ombros e se move para baixo em direção ao espaço neutro, já o sinal UNREADABLE PRINTOUT ‘impressão ilegível' inicia-se na locação espaço neutro e movese à direita, conforme podem ser conferidos na figura 5 . 
Figura 5 - Sinais CHINESE SCRIPT e UNREADABLE PRINTOUT

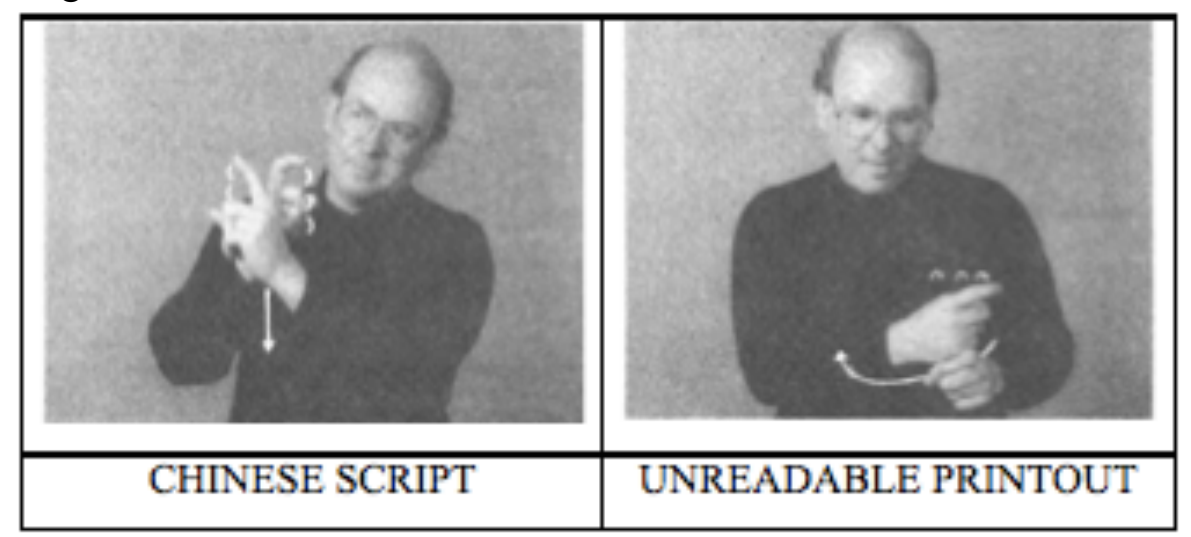

Fonte: Brennan (1990, p.162)

\subsubsection{Flexão em LS}

Quadros e Karnopp (2004, p. 111-112), ao tratar de flexão em LS, citam oito processos diferentes com base nos estudos realizados por Klima e Bellugi na ASL e apresentam as seguintes flexões: de pessoa, de número, de grau, de modo, de reciprocidade, de foco temporal e de aspecto distributivo.

Nesta pesquisa, interessa-nos apenas a flexão de número. Isso porque o nosso objetivo é uma proposta terminográfica. Sabemos que o lema, palavra entrada do verbete, apresenta-se nos glossários com uma forma não marcada. Todavia, o plural em LS se manifesta de diversas formas e sendo assim, decidimos que a forma plural do termo em língua de sinais pode constar em determinados verbetes.

Costello (1994, p. xv) esclarece que o plural em ASL pode ser realizado de várias formas; não existe apenas uma marca para evidenciar o plural. Para caracterizar o plural, pode-se usar um numeral, como em três gatos ou uma palavra com um significado de mais do que um, como em um bando de gatos. A reduplicação também é mencionada como uma forma de marcar o plural na ASL. Costello explica que o sinal CAT 'gato' é constituído apenas por um movimento e o plural pode ser formado repetindo o sinal uma ou mais vezes. A autora ainda explana que a reduplicação do verbo também é um método de formação de plural, embora frequentemente o resultado seja para expressar duração e ação repetitiva. Outra forma de plural é a apontação para vários locais.

Quanto à flexão de número, a LSB tem marca para singular, dual, trial e para mais de quatro. A pluralização nessa língua pode ocorrer no léxico ou na sentença apresentando por exemplo um numeral, como também ocorre em ASL. Todavia, alguns sinais isolados podem 
apresentar a marca que diferencia "um" de "mais de um". Além disso, como já dito, os classificadores podem funcionar como marcadores de plural em LSB.

\subsubsection{Empréstimos}

A LSB pode importar palavras de outras LS e do Português, língua de maior contato. As LS, mesmo sendo de modalidade visual e espacial, importam mais itens lexicais de uma língua oral do que de uma LS. Isso se deve ao intenso contato de determinada língua de sinais com uma língua oral específica. Quanto a isso, Sutton-Spence e Woll (1999 esclarecem que:

Na BSL, o inglês é a língua com o maior número de doações, não outras línguas de sinais. Isso ocorre porque todas as línguas realizam empréstimos, principalmente da língua com a qual mantêm um contato maior. Os sinalizantes (ou usuários de sinais) britânicos têm mais contato com o inglês, portanto, adquirem mais empréstimos do inglês." (SUTTON-SPENCE e WOLL 1999, p. 216, tradução e grifo nosso). ${ }^{18}$

Desse intenso contato entre uma LS e uma LO, no nosso caso, o contato da LSB com a LP, surge a influência da língua majoritária sobre a LSB, que pode ocorrer de diversas formas. Faria-Nascimento (2009) criou uma tipologia de empréstimos provenientes da LP para a LSB. Ela classificou os empréstimos da LP para a LSB em: empréstimo por transliteração, empréstimo da configuração visual dos lábios (CVL), empréstimo semântico (decalque), empréstimo estereotipado e empréstimo cruzado.

Para Faria-Nascimento (2009, p. 61), transliteração é a "representação de letras de uma língua oral por CMs de uma língua de sinais”. Além disso, explica que:

o termo datilologia é aplicado a um dos aspectos de uso da transliteração, pois refere-se à representação, em língua de sinais, de palavras ou parte de palavras de línguas orais por meio do uso agrupado de CMs equivalentes à representação de letras do alfabeto de dada língua oral, em um PA específico.

Em outras palavras, a datilologia é uma das manifestações da transliteração e ocorre em um PA específico, em geral, no espaço neutro. Por sua vez, Wilcox (1992 apud Wilcox e Morford, 2007, p.172-173) afirma que:

\footnotetext{
${ }^{18}$ Texto original: "For BSL, English is the major donor language, not other sign languages. This is because all languages borrow most from the language they have most contact with. Bristish signers have most contact with English, so they borrow from English.” (SUTTON-SPENCE e WOLL 1999, p. 216).
} 
A datilologia é mais do que uma sequência canônica de configurações de mão, já que os movimentos articulatórios que formam uma palavra digitada são mutuamente influenciados. A coarticulação que se repete e que acontece de forma antecipada afeta a real configuração das palavras digitadas, por meio da datilologia, gerando uma transição fluida entre as letras. (WILCOX, 1992 apud WILCOX e MORFORD, 2007, p.172-173, tradução de Marcela Bravo Esteves) ${ }^{19}$

Faria-Nascimento (2009) organiza os empréstimos por transliteração em três tipos: pragmática, lexicalizada e da letra inicial.

O empréstimo por transliteração pragmática, geralmente, é provisório e usado em momentos de interação em que não há um correspondente em LSB, ou quando um dos interlocutores não conhece o sinal da LSB que equivalha à palavra em Português.

O empréstimo por transliteração lexicalizada é mais estável na língua e, às vezes, está tão adaptado à língua receptora que não é mais identificado como empréstimo pelos sinalizantes, como ocorre com os sinais \# ${ }^{20}$ TUDO, \#NUNCA e \#SOL.

O empréstimo por transliteração da letra inicial é mais conhecido na literatura como inicialização. Nesse tipo de importação, a CM do sinal é emprestada da letra inicial da palavra escrita em LP, como no sinal BRASIL em que a CM eleita para a produção do sinal corresponde à letra $\mathrm{B}$, ou como no sinal PEDAGOGIA em que a $\mathrm{CM}$, eleita para a produção do sinal, corresponde à letra $\mathrm{P}$.

Vale acrescentar que os sinais motivados pela datilologia podem sofrer alterações para acomodar elementos emprestados. Valli et. al (2011, p. 75-79), com base na descrição feita primeiramente por Battison (1978), listam os seguintes processos de lexicalização de empréstimos oriundos da língua oral, que são: algumas CMs podem ser apagadas, o ponto de articulação pode ser modificado, a CM pode ser modificada, um movimento pode ser adicionado, a orientação da palma pode ser modificada, o movimento pode ser reduplicado, uma segunda mão pode ser adicionada e, por fim, uma informação gramatical pode ser adicionada.

A configuração visual dos lábios é uma imitação completa ou parcial da articulação dos lábios de uma palavra da língua oral. Esse empréstimo pode ser usado para tirar a

\footnotetext{
${ }^{19}$ Texto original: "Fingerspelling is more than a sequence of canonical handshape configurations, since the articulatory movements within the fingerspelled word influence each other. Perseverative and anticipatory coarticulation affects the actual shaping of fingerspelled words, creating a fluid transition between letters." (WILCOX, 1992 apud WILCOX e MORFORD, 2007, p.172-173).

${ }^{20} \mathrm{O}$ símbolo jogo da velha (\#) tem sido usado na literatura da ASL para indicar um sinal motivado pela datilologia da palavra em Inglês, mas que se acomodou à língua receptora. Da mesma forma, usamos aqui esse símbolo para indicar sinais motivados pela LP escrita, porém, se adaptaram à fonologia da língua receptora.
} 
ambiguidade de homonímias manuais. Tal mecanismo é conhecido na literatura como mouth pattern, todavia, ainda não há estudos suficientes que comprovem a regularidade desse empréstimo na LSB.

O empréstimo semântico, também conhecido por decalque, é uma tradução literal da LP para a LSB. Esse tipo de empréstimo não é fácil de ser identificado, serve de exemplo a palavra café da manhã que em LSB é uma tradução literal, pois é composto do sinal CAFÉ mais o sinal MANHÃ.

O empréstimo estereotipado é a representação no ar de símbolos matemáticos, formas geométricas, sinais de pontuação, convencionados em diversas culturas. Em geral, são executados com o dedo indicador. Serve de exemplo o sinal que representa o ponto de interrogação, desenha-se no ar esse 'ponto'.

O empréstimo cruzado é um tipo de importação em que, por semelhança na escrita das palavras da LP, que podem ser homônimas, homógrafas ou parônimas, recebem o mesmo sinal na LSB, como CARNE e CARNÊ, ainda que não tenham qualquer relação semântica ou de referência. Isso ocorre porque em LP escrita, as palavras carne e carnê são visualmente parecidas.

Os empréstimos de outras LS são menos frequentes, mas podem ser uma alternativa de expansão lexical. Essas importações podem entrar na língua receptora com ou sem adaptação. Um tipo de empréstimo muito comum entre as LS é o empréstimo dos sinais referentes aos países. Serve de exemplo a LSB que tomou emprestado o sinal do país Portugal da Língua Gestual Portuguesa. Também a ASL, que tomou emprestado o sinal de Austrália da AUSLAN, Língua de Sinais Australiana (figura 6).

Figura 6 - Sinal AUSTRÁLIA em ASL e sinal AUSTRÁLIA emprestado da AUSLAN

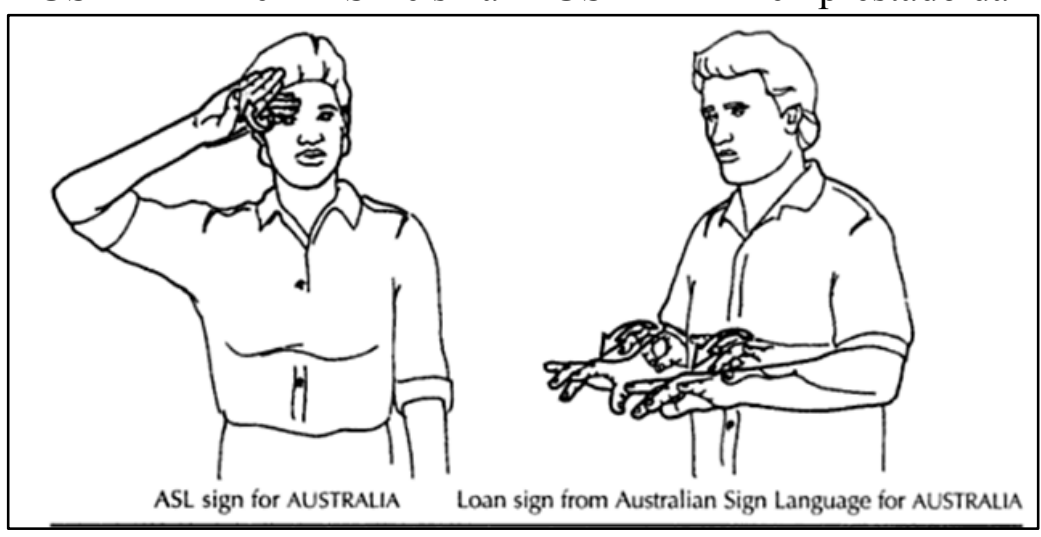

Fonte: Valli e Lucas (2000, p. 69) 


\subsection{Restrições na criação de sinais}

As línguas de sinais também apresentam restrições na criação de novos itens lexicais. Essas podem ser de natureza cultural e fonológica, física e linguística.

A restrição cultural pode ocorrer na seleção de CMs, por exemplo. Quadros e Karnopp (2004, p.70) mencionam que a extensão do dedo médio ou anular parece ser tabu social em muitas culturas.

As restrições fonológicas para Quadros e Karnopp (2004, p. 78) podem ser decorrentes do canal receptivo ou pelo sistema articulatório que influenciam na criação e na aceitação de novos sinais. Esses impedimentos podem referir-se às restrições físicas ou linguísticas. As restrições físicas estão relacionadas ao tipo de modalidade de língua, espacial e visual. Grande parte dos sinais são produzidos na frente do corpo. Existem poucos sinais que são produzidos atrás do corpo. Os sinais são mais numerosos onde a acuidade visual é maior.

As restrições fonológicas foram sistematizadas por Battison (2011), que postulou as restrições de Condição de Simetria e de Condição de Dominância para sinais realizados com as duas mãos.

Nas restrições linguísticas, os sinais em condição de simetria possuem as duas mãos ativas e devem ser produzidos com a mesma CM em ambas as mãos, o ponto de articulação também deve ser o mesmo ou simétrico e o movimento simultâneo ou alternado. Servem de exemplos os sinais FAMÍLIA e TRABALHAR.

Já na condição de dominância, uma das mãos é dominante ${ }^{21}$ e a outra é não dominante $^{22}$, os sinais apresentam CM distintas, então a mão ativa produz o movimento, e a mão passiva serve de apoio, apresentando um conjunto restrito de CM não marcadas. Como exemplo, podemos citar os sinais AJUDAR e CONVERSAR.

Quadros e Karnopp (2004, p. 92-93) declaram haver exceção às restrições fonológicas de condição de simetria e de dominância, quando afirmam que os classificadores podem violar essas restrições.

\footnotetext{
${ }^{21}$ Nesta pesquisa, consideramos os termos "mão dominante" como sinônimo de "mão ativa" .

${ }^{22}$ Nesta pesquisa, consideramos os termos "mão não dominante" como sinônimo de "mão passiva".
} 


\subsection{Síntese do capítulo}

Neste capítulo, apresentamos as pesquisas sobre criação de sinais em algumas LS e as discussões que envolvem a constituição dos sinais nestas línguas. Esse capítulo contribui de forma a nos orientar sobre a pertinência dos sinais-termo criados nessa pesquisa, uma vez que os estudos sobre criação de sinais permitem compreender alguns mecanismos de criação para que, dessa forma, seja possível verificar se os sinais obedecem às regras previstas na LSB ou, ao menos, se já há estudos a respeito de determinados fenômenos relacionados à criação de sinais nas línguas estudadas. No próximo capítulo, tratamos de Terminologia e de Lexicografia das LS, que dão suporte teórico tanto para a criação dos sinais-termo quanto para a proposta do glossário. 


\section{CAPÍTULO 2: TERMINOLOGIA E LEXICOGRAFIA DA LÍNGUA DE SINAIS}

\subsection{Os desafios da lexicografia das línguas de sinais}

O lexicógrafo de uma língua de sinais precisa ter em mente que, além dos desafios comuns a todos os profissionais, outras dificuldades específicas das línguas de sinais precisam ser superadas. Zwitserlood (2010, p. 444-445), psicolinguista e pesquisador da Língua de Sinais Holandesa, em artigo sobre a Lexicografia das línguas de sinais, menciona quatro desafios da Lexicografia destas línguas.

O primeiro é que não há uma ortografia para as LS. Mesmo que existam vários sistemas de notação em desenvolvimento, nenhum deles tem uma aceitação geral. O segundo desafio é que em quase todos os países, existem apenas algumas fontes de sinais, a partir da qual os significados e características gramaticais dos sinais podem ser deduzidos e as frequências podem ser calculadas. O terceiro é que as línguas de sinais são bastante diferentes das línguas orais. Nesse caso, as línguas de sinais podem ter uma estrutura complexa, na qual a língua falada tem uma palavra simples e a LS tem o mesmo item lexical complexo, ou viceversa. Muitas vezes, é difícil ter na tradução uma palavra para um sinal ou um sinal para uma palavra. Por último, ele diz que os lexicógrafos das línguas de sinais têm de superar o legado de uma tradição de compilação inadequada dos dicionários de línguas de sinais criados por não profissionais.

Além dessas dificuldades mencionadas por Zwitserlood, podemos listar muitos outros desafios como a ausência de sinais acadêmicos em LSB ou inadequação terminológica dos sinais. Há também o desafio de adequar a linguagem à faixa etária e à LP como segunda língua. Enfrentamos, por outro lado, a dificuldade de representar por meio de ilustrações diversos conceitos terminológicos, o que não é um desafio exclusivo das obras lexicográficas das línguas de sinais. Ressaltamos que a obra terminográfica proposta não apresenta a definição em LSB, língua mais acessível aos surdos. Desse modo, as ilustrações têm papel fundamental de auxiliar o entendimento dos conceitos do Meio Ambiente, tendo em vista que a LP é considerada difícil pelo público-alvo.

Para um trabalho correto, o lexicógrafo necessita de uma equipe composta por outros profissionais, como o programador para o desenvolvimento de um software que atenda as especificidades das LS e permita a adição de vídeos. O lexicógrafo depende ainda de outros participantes, como um operador de câmara e um ator surdo para reproduzir os sinais da LSB. 
Quanto ao ator surdo, poderíamos pensar em substituí-lo por avatares ${ }^{23}$, como os encontrados nos aplicativos handtalk e prodeaf, porém os avatares não realizam movimentos manuais e não manuais como uma pessoa e podem comprometer a execução do sinal, ainda que estes aplicativos já estejam bastante desenvolvidos em relação às expressões faciais e corporais.

Outro desafio, diretamente relacionado à não aceitação geral de um sistema de escrita para as LS, é a manipulação de vídeos. Esta é uma atividade muito mais complexa do que o sistema de escrita, porque exige que o sinais sejam filmados. As filmagens exigem a presença de um ator surdo, estúdio com iluminação adequada e as demais tecnologias, como câmera e um profissional de filmagens. Ao final, a edição também faz parte do trabalho pós-filmagem, que é mais trabalhosa do que editar textos escritos.

Diante de todos esses desafios explicitados na confecção de uma obra lexicográfica para LS, apresentamos, neste capítulo 2, algumas reflexões sobre Terminologia, Política Linguística e Lexicografia nas Línguas de Sinais, principalmente na LSB, com vista a encontrar caminhos para criação da obra terminográfica. Mostramos algumas obras terminológicas e lexicográficas a fim de apresentar registros desenvolvidos para as LS que contribuíram com a nossa proposta de glossário. Tratamos também de obras semibilíngues e ilustradas. Além disso, discutimos a definição em obras lexicográficas que tenham como público-alvo os surdos.

\subsection{Terminologia}

Para iniciar a discussão, primeiramente apresentamos os conceitos e as funções da Terminologia que nos interessam nesta pesquisa. O termo Terminologia pode ser definido de formas diferentes. Cabré (1993, p. 82) menciona três acepções para Terminologia. A primeira significa o "conjunto dos princípios e das bases conceituais que determinam o estudo dos termos"; a segunda, "conjunto dos princípios e métodos utilizados em um trabalho terminológico"; e, por último, o "conjunto dos termos de uma área de especialidade". O sentido que nos atemos nesta pesquisa é o último, em especial, o conjunto de termos da área do Meio Ambiente na LP e na LSB .

Ainda que as acepções sejam diferentes, há algo em comum em todos os três sentidos apresentados - todas compreendem a terminologia no âmbito do léxico especializado.

\footnotetext{
${ }^{23}$ Martins, Ferreira e Mineiro (2012, p. 23 ) definem os avatares como "figuras tridimensionais que permitem representar em tempo real dos gestos das línguas gestuais a partir de informação abstrata subjacente préprogramada."
} 
Para Biderman (2001, p. 163), os objetivos da Terminologia são normalização/ padronização. No caso específico da LSB, acreditamos que o objetivo primeiro seja prover a LSB com terminologias para fins acadêmicos.

O trabalho terminológico possui uma forte relação com a Lexicografia, por isso, tratamos dessas áreas neste mesmo capítulo. Sobre esta relação, Boulanger (2001, p. 9) explica que o termo Terminologia "remete à atividade dicionarística relativa ao(s) léxico(s) das línguas de especialidade ou aos tecnoletos".

Na continuidade deste capítulo, passamos a discorrer sobre a Terminologia no estudo da LSB relacionado à Lexicografia. Contudo, antes disso, é preciso esclarecer alguns conceitos sobre Terminologia em geral.

\subsubsection{A importância da Terminologia}

Para desenvolver uma pesquisa de Terminologia existem métodos e princípios que regem a prática do trabalho terminológico. Comecemos pela ISO $^{24} 704$ de 2000, um documento internacional que apresenta princípios e métodos para o trabalho terminológico. Em especial, desse documento, interessa-nos os princípios do trabalho terminológico para formação de termos, conforme dispõe a ISO nas páginas 25-27, que são transparência, coerência, adequação, economia linguística, derivabilidade, correção linguística e preferência pela língua nativa. A seguir, apresentamos cada item.

A Transparência ocorre quando "o conceito de um termo pode ser inferido, pelo menos parcialmente, sem uma definição. Isso quer dizer que o significado do termo é visível na morfologia"25 (ISO, 704:2000, p. 25, tradução nossa). Este conceito de transparência é semelhante ao que Correia $(2009$, p. 78) explicita ao explicar o que são palavras transparentes. Para ela, itens lexicais cujo significado pode ser depreendido pela estrutura da palavra são transparentes.

A Coerência é manifestada quando "a terminologia de qualquer campo é organizada como um sistema terminológico coerente correspondente ao sistema de conceito, e não uma

\footnotetext{
${ }^{24}$ International Organization for Standardization ‘Organização Internacional para padronização'.

25 "Concept it designates can be inferred, at least partially, without a definition. In other words, its meaning is visible in its morphology." (ISO 704:2000, p.25)
} 
coleção arbitrária e aleatória de termos. Os termos existentes e novos termos devem integrarse e ser coerentes com o sistema de conceito" ${ }^{26}$ (ISO, 704:2000, p. 26, tradução nossa).

Outro princípio é a Adequação, que ocorre quando "os termos propostos aderem aos padrões familiares, estabelecidos de significado dentro de uma comunidade linguística. A formação de termos que provoquem confusão devem ser evitados. Os termos deverão ser o mais neutro possível e, além disso, devem evitar conotações, especialmente as negativas",27 (ISO, 704:2000, p. 26, tradução nossa).

A Economia linguística "se caracteriza por designações mais concisas possíveis. A extensão indevida é considerada uma lacuna grave. Isso viola o princípio da economia linguística e frequentemente leva a elipses, omissões... A exigência de concisão, muitas vezes, porém, entra em conflito com a exatidão" ${ }^{28}$ (ISO, 704:2000, p. 26-27, tradução nossa).

Já a Derivabilidade é a característica de "produtividade dos termos que deve permitir a formação de derivados"29 (ISO, 704:2000, p. 27, tradução nossa), enquanto o princípio da Correção linguística prima pela "observância dos termos às normas morfológicas, morfossintática e fonológicas da língua em questão" ${ }^{30}$ (p. 27, tradução nossa).

Por fim, a Preferência pela língua nativa é o princípio que estabelece que é preferível uma forma na língua nativa em detrimento às formas linguísticas estrangeiras. “Apesar do empréstimo linguístico de outras línguas ser uma forma aceitável de criação de termos, as expressões das línguas nativas devem sempre ter preferência frente aos empréstimos diretos" ${ }^{31}$ (ISO 704:2000, p. 27, tradução nossa). A esse respeito, Quadros e Karnopp (2004, p. 88) advertem que os empréstimos estão na "periferia da LSB" não sendo, portanto, o mecanismo mais produtivo na língua. Dessa forma, os empréstimos, como parte dos processos de inovação lexical e terminológica da língua, provavelmente, não serão muito

\footnotetext{
${ }^{26}$ Texto original: "The terminology of any subject field should not be an arbitrary and random collection of terms, but rather a coherent terminological system corresponding to the concept system. Existing terms and new terms must integrate into and be consistent with the concept system." (ISO, 704:2000, p. 26).

${ }^{27}$ Texto original: "Proposed terms should adhere to familiar, established patterns of meaning within a language community. Term formations that cause confusion shall be avoided. Terms shall be as neutral as possible. They should avoid connotations, especially negative ones." (ISO, 704:2000, p. 26).

${ }^{28}$ Texto original "A term shall be as concise as possible. Undue length is a serious shortcoming. It violates the principle of linguistic economy and it frequently leads to ellipsis (omission)... The requirement for conciseness often conflicts with that for accuracy." (ISO, 704:2000, p. 26-27).

${ }^{29}$ Texto original "Productive term formations that allow derivatives should be favoured." (ISO, 704:2000, p. 27).

${ }^{30}$ Texto original "A term shall conform to the morphological, morphosyntactic and phonological norms of the language in question." (ISO, 704:2000, p. 27).

${ }^{31}$ Texto original: "Even though borrowing from other languages is an accepted form of term creation, native language expressions should be given preference over direct loans." (ISO 704:2000, p. 27).
} 
comuns nos sinais-termo, já que a terminologia também é parte da língua e segue os mesmos princípios de neologismos.

Esses princípios de formação de termos serviram de guia para o desenvolvimento e a avaliação dos sinais-termo em LSB que são apresentados no capítulo 4.

\subsection{A terminologia em Língua de Sinais diante das políticas linguísticas}

As terminologias das mais diversas áreas técnicas e científicas têm sido organizadas em léxicos, dicionários, glossário nas Línguas de Sinais. Isto se deve às conquistas de inclusão social dos surdos, que têm ocupado ambientes em que o vocabulário de LS precisa ser ampliado para a plena participação dos surdos, principalmente, nos espaços acadêmicos e técnico.

Grande parte dessas conquistas sociais são decorrentes de manifestações da comunidade Surda, que é fortalecida por meio de políticas linguísticas. Para nossa discussão, interessa-nos alguns conceitos relacionados às políticas de língua de sinais que contribuem com as discussões desta pesquisa e, além disso, motivam e reafirmam a necessidade de se desenvolver terminologias para a LSB.

Para Calvet (2002, p.145), política linguística é "um conjunto de escolhas conscientes referentes às relações entre língua(s) e vida social.” e, de acordo com Calvet (2007, p. 11) é a “determinação das grandes decisões referentes às relações entre as línguas e a sociedade". Nesta pesquisa, é de nosso interesse discutir o planejamento linguístico, em especial, o planejamento de corpus dos termos acadêmicos na Língua de Sinais Brasileira. Compreendemos o Planejamento linguístico como a prática da política, isto significa dizer que é a implementação da política linguística.

Calvet (2007, p. 29) apresenta dois tipos de planejamento linguístico introduzidos por Kloss (1967): o planejamento de status e o de corpus. O planejamento de status é uma intervenção na "função da língua". O status social de uma determinada língua em relação às outras línguas é de interesse deste planejamento linguístico. A oficialização de uma língua é um tipo de planejamento de status. Já o planejamento de corpus é uma intervenção mais relacionada à "forma da língua", como a "criação de uma escrita, de neologia, de padronização", de provimento de terminologia, entre outros.

Ao tratar de planejamento de corpus, Calvet (2007, p. 62) apresenta o primeiro sentido do verbo equipar que é "prover uma embarcação do necessário para cumprir serviço ou realizar missão". Esta é uma metáfora que serve para a LSB que precisa ser equipada de 
terminologias científicas para cumprir a função de língua de ensino usada na escola. Sobre equipar uma língua, Calvet argumenta que é óbvio que "uma língua ágrafa não pode ser veículo de uma campanha de alfabetização", ou mesmo que será difícil "ensinar informática numa língua que não disponha de vocabulário computacional", mas que "se, entretanto, por razões políticas, se desejar utilizar essas línguas nessas funções, será necessário reduzir seus déficits e equipá-las para que possam desempenhar seu papel” (CALVET, 2007, p. 62).

É preciso observar que apenas a criação de sinais terminológicos na LSB não solucionará a comunicação nos ambientes acadêmicos. É preciso discutir um planejamento de corpus da LSB em esfera nacional para a padronização dos usos acadêmicos. O intuito de se criar uma norma para usos educacionais, técnicos e profissionalizantes é o de contribuir com o acesso às informações, com o entendimento de fenômenos científicos, comunicação com os pares e compreensão do mundo pelos surdos, o que ainda não é feito com consistência. Além disso, uma medida dessa natureza visa a controlar o excesso de formas concorrentes de um mesmo termo ou a omissão de conteúdos complexos e especializados.

Reagan (2006, p. 334) afirma que "o planejamento de corpus nas línguas de sinais pode ser classificado em cinco categorias: lexicografia, criação e expansão lexical, produção de livros escolares, criação de códigos manuais e o desenvolvimento de sistemas ortográficos para representar as LS". Pesquisadores estrangeiros têm chamado atenção para a necessidade de planejamento linguístico. Em 2004, Tovar escreveu um artigo intitulado La necesidad de planificar una norma linguística en lengua de señas para usos académicos, em que discorre sobre a necessidade de um planejamento linguístico na Língua de Sinais Colombiana (LSC) para funções acadêmicas, que possam contribuir com a educação bilíngue e o desenvolvimento cognitivo dos surdos.

Esse mesmo pesquisador, em 2010, publicou o artigo La creación de neologismos en la lengua de señas colombiana. Nesse texto, Tovar explica sobre a necessidade de um planejamento linguístico para a LSC, como forma de controle de neologismos nesta língua. Ele expõe o problema que a LSC tem enfrentado, explicando que um grupo politizado, chamado "Árbol de vida", tem proposto termos em LSC para diversas áreas, todavia, os sinais criados têm sido rejeitados por outros grupos da comunidade Surda da Colômbia. Isto se dá porque alguns grupos consideram os sinais ilógicos e porque estes não contribuem para a apreensão de novos conceitos, em especial os escolares. Tovar apresenta também um estudo cujo objetivo é identificar os processos produtivos na formação de palavras em LSC, a fim de contribuir com a dissolução do conflito relacionado ao planejamento linguístico em curso. Ele 
apresenta quais são os recursos mais recorrentes de neologismo nesta língua e deixa as reflexões para que os sinalizantes da LSC solucionem seus conflitos linguísticos.

Na subseção seguinte, apresentamos os documentos legais que estão relacionados ao planejamento linguístico da LSB.

\subsubsection{Os marcos legais e os direitos linguísticos dos surdos no Brasil}

O planejamento linguístico de status da LSB, com o reconhecimento oficial da Língua de Sinais Brasileira pela Lei de Libras, possibilitou várias conquistas legais que podem ser somadas a esse status de língua dos surdos brasileiros. A seguir, apresentamos a sistematização de Gotti sobre os direitos linguísticos dos surdos, a partir do marco da Lei de Libras. Gotti $(2015)^{32}$ sistematizou os direitos linguísticos dos surdos, garantidos pela legislação brasileira a partir da Lei de Libras, nos seguintes marcos legais:

- A Lei n 10.436, de 24 de abril de 2002, reconhece legalmente a Língua Brasileira de Sinais - Libras - como meio de comunicação das comunidades surdas do Brasil e dispõe acerca da difusão desta língua nas instituições públicas, nas empresas concessionárias de serviços públicos e no sistema educacional;

- $\quad$ O Decreto $\mathrm{n}^{\circ} 5.296 / 2004$ regulamenta as Leis $\mathrm{n}^{\circ} 10.048 / 2000$ e $\mathrm{n}^{\circ} 10.098 / 2000$ que dispõem sobre a acessibilidade ${ }^{33}$ das pessoas com deficiência. Esse decreto, especificamente em relação aos surdos, discorre acerca da necessidade dos serviços de interpretação da LSB, bem como versa sobre outras providências que garantem a acessibilidade dos surdos, como a disponibilidade de telefone adaptado, o incentivo ao uso de recursos tecnológicos como legendas, os recursos de "circuito de decodificação de legenda oculta", o recurso para Programa Secundário de Áudio (SAP), a janela com intérprete de Libras, a promoção de capacitação para profissionais em Libras, as tecnologias de informação e comunicação;

\footnotetext{
${ }^{32}$ Aula inaugural da Licenciatura em Língua de Sinais Brasileira - Português Segunda Língua, ministrada no Auditório do Instituto de Letras da Universidade de Brasília, no dia 13 de Março de 2015. O título da exposição foi "Direitos Linguísticos dos Surdos, garantidos pela Legislação Brasileira: Ações efetivadas no período de 2002 a 2014".

${ }^{33}$ Conforme o Decreto 5.296/2004, Art $8^{\circ}$, inciso I, acessibilidade é "condição para utilização, com segurança e autonomia, total ou assistida, dos espaços, mobiliários e equipamentos urbanos, das edificações, dos serviços de transporte e dos dispositivos, sistemas e meios de comunicação e informação, por pessoa portadora (sic) de deficiência ou com mobilidade reduzida.
} 
- O Decreto $\mathrm{n}^{\circ} 5.626 / 2005$ regulamenta a Lei de Libras $\mathrm{n}^{\circ} 10.436 / 2002$ e o art. 18 da Lei $\mathrm{n}^{\circ} 10.098 / 2000$. Esse decreto determina a inserção da Libras como disciplina curricular obrigatória nos cursos de formação de professores e profissionais da Educação para o exercício do magistério, discorre sobre a formação do professor de Libras e do Instrutor de Libras, delibera sobre o uso e a difusão da Libras e da Língua Portuguesa para o acesso das pessoas surdas à educação, versa acerca da formação do tradutor e intérprete de Libras-Língua Portuguesa, determina a garantia dos direitos dos surdos à educação e à saúde, e trata do papel do poder público e das empresas que detêm concessão ou permissão de serviços públicos, no apoio ao uso e difusão da Libras;

- O Decreto $n^{\circ}$ 6.949/2009, que promulga a Convenção sobre os Direitos das Pessoas com Deficiência (ONU), com status de emenda constitucional, delibera acerca da aceitação do uso de línguas de sinais em trâmites oficiais, reconhece e promove o uso de língua de sinais, além disso, promove a identidade linguística da comunidade surda;

- A Resolução do CNE/CEB n 4/2009 institui as Diretrizes para o Atendimento Educacional Especializado (AEE) na Educação Básica - modalidade educação especial. Especificamente em relação aos surdos, o Art. 10, inciso VI, afirma que o projeto pedagógico da escola deve prever profissionais da educação como Tradutor e Intérprete de Língua de Sinais Brasileira;

- A Lei $n^{\circ} 12.319 / 2010$ regulamenta a profissão de tradutor e intérprete de Libras Língua Portuguesa, nível médio, e dispõe sobre as atribuições e competências desta profissão;

- Portaria do MEC $n^{\circ} 1.328 / 2011$, que institui a Rede Nacional de formação continuada dos Profissionais do Magistério da Educação Básica - Renaform. Essa Portaria discorre sobre a formação continuada de um modo geral;

- Decreto $\mathrm{n}^{\circ} 7.611 / 2011$ trata do atendimento educacional especializado, complementar ou suplementar à escolaridade, no âmbito do Fundo de Manutenção e Desenvolvimento da Educação Básica e de Valorização dos Profissionais da Educação - FUNDEB (dupla matrícula e duplo financiamento);

- Decreto $\mathrm{n}^{\circ} 7.612 / 2011$ institui o Plano Nacional dos Direitos das Pessoas com Deficiência denominado Plano viver sem Limite. Esse plano tem como eixos de atuação, a saber, o acesso à educação, a atenção à saúde, a inclusão social e a acessibilidade; 
- Portaria do MEC $\mathrm{n}^{\circ}$ 1.060/2013 institui o Grupo de Trabalho com o objetivo de elaborar subsídios para a política nacional de educação bilíngue - Língua Brasileira de Sinais e Língua Portuguesa como segunda língua;

- Portaria do MEC n 334/2014 institui a Comissão Técnica do Prolibras, que é o Programa Nacional para a Certificação de Proficiência no Uso e Ensino da Língua Brasileira de Sinais - Libras e para a Certificação de Proficiência em Tradução e Interpretação da Libras/Língua Portuguesa;

- Lei n $^{\circ}$ 13.005/2014 aprova o Plano Nacional de Educação (PNE) com duração de 10 anos. Em relação aos surdos, destacamos do PNE, a estratégia de "fomentar a oferta do atendimento educacional especializado complementar e suplementar aos(às) alunos(as) com deficiência” e dessa forma, assegurar a educação bilíngue para crianças surdas. Também visa garantir a educação bilíngue em escolas, classes bilíngues e escolas inclusivas.

Acrescentamos a essa lista a Lei $\mathrm{n}^{\circ}$ 13.146/2015 - Lei Brasileira de Inclusão da Pessoa com Deficiência - denominada Estatuto da Pessoa com Deficiência. Esta lei reafirma que os surdos têm direito à "oferta de educação bilíngue, em Libras como primeira língua e na modalidade escrita da Língua Portuguesa como segunda língua, em escolas e classes bilíngues e em escolas inclusivas”. Existem também projetos de leis municipais, como o PL 13/2010 do Município de Foz do Iguaçu do Estado do Paraná e o PL 90/2013 da Câmara Municipal de São Paulo para as escolas da capital paulista - que propõem ofertar o ensino de LSB desde a educação infantil até o ensino fundamental, como disciplina curricular obrigatória, bem como em escolas bilíngues para surdos, onde a LSB é a língua usada para comunicação e ensino. Essas escolas precisam de materiais didáticos, dicionários, glossários, léxicos que vão ao encontro das necessidades linguísticas e educacionais dos surdos.

\subsubsection{A importância da terminologia nas LS}

Em geral, as pessoas lidam com as terminologias no seu dia a dia. Faulstich (1998, p. $10 ; 2006$, p. 27; 2013, p. 66) vem chamando a atenção para o uso quotidiano das terminologias no espaço da interação social, quando diz:

Diferentemente da compreensão de que os termos só aparecem em situações de comunicação especializada, pode-se constatar que, na interação conversacional, cerca de $80 \%$ do vocabulário é constituído de termos específicos de acordo com o contexto em que se desenvolve a comunicação. 
(...) Recorde-se a seleção terminológica que se faz, de modo natural, na conversa do dia a dia, nos eventos quotidianos, nos meios profissionais, no preparo de refeições, na descrição de cardápios, nas reuniões técnicas e científicas, nas pesquisas, na metalinguagem do ensino, no comércio, nas indústrias, nos diversos tipos de meios de transporte, entre outros. As terminologias estão, portanto, no vocabulário prático de todo dia do adulto e da criança.

Visto dessa forma, os surdos, assim como os ouvintes, têm o direito de ter a linguagem de especialidade organizada, a fim de facilitar o aprendizado no âmbito escolar e de ter acesso ao entendimento das línguas com coerência.

Para isso é preciso equipar a LSB para que seja efetivamente uma língua de interação. Há diversas justificativas para organizar as terminologias em LSB para usos escolares, uma delas é o excesso de variação, embora seja de conhecimento que as línguas variam e mudam por causas diversas; e, por conseguinte, a terminologia, que é língua, também é afetada por mudanças.

Uma das causas de mudanças nas terminologias é o avanço dos conhecimentos, dos métodos e dos instrumentos científicos. O Ambiente é uma área que recebe atenção mundial, portanto os constantes estudos acerca das condições de vida atualizam com frequência a terminologia quotidiana e a especializada.

Como percebemos, a plena inserção de surdos em atividades escolares, científicas e profissionais depende de políticas linguísticas que estimulem a padronização de terminologias com base em termos bem construídos na língua de sinais, elaborados por equipes qualificadas e bem elaborados, materiais especializados como glossários e dicionários terminológicos bilíngues com ampla difusão nacional. Esta tese vem apresentar uma proposta de desenvolvimento de terminologia, no caso, a do Meio Ambiente, e apresenta um produto, um glossário, que pode contribuir para a fixação da terminologia acadêmica em âmbito nacional.

O ensino da LSB, até o momento, não é obrigatória nas escolas, mas já é no ensino superior em cursos de formação de professores, como as licenciaturas.

O objetivo de fixarem-se terminologias bilíngues é permitir que não só o estudante surdo mas também os professores e intérpretes tenham acesso ao conhecimento científico em LS. Criar termos de uma determinada área em LS ainda é uma tarefa difícil, porque nem sempre temos colaboradores surdos. Para a nossa pesquisa, por exemplo, gostaríamos que os participantes tivessem o seguinte perfil: proficiência em LSB, de preferência que tivessem adquirido a língua na mais tenra idade e que tivessem, no mínimo, formação superior em Biologia, Ciências Biológicas ou alguma área afim do Meio Ambiente. Entretanto, como o 
perfil desejado é difícil de encontrar, estabelecemos outro público para as sessões de criação, que é apresentado no capítulo 3.

Hoje, no Brasil, temos uma terminologia dispersa. O que tem ocorrido é a situação em que cada grupo cria suas terminologias para determinadas áreas e não há uma discussão em âmbito nacional. O desenvolvimento de terminologias na LSB ainda é uma tarefa de grupos isolados. Essa prática continua a comprometer a comunicação entre os pares surdos e os profissionais que precisam de determinada terminologia para se comunicar em níveis cada vez mais especializados. É inegável que existam esforços para a divulgação de terminologias de diversas áreas em LSB, como vem sendo feito em diversas universidades brasileiras, por exemplo, nos estudos dessa área na Universidade Brasília, desde 2012, como mostramos a seguir.

Em 2012, Messias Ramos Costa defendeu a dissertação "Proposta de modelo de enciclopédia visual bilíngue juvenil: Enciclolibras”. Nesta pesquisa, Costa desenvolve um modelo de material didático que pode ser classificado como uma enciclopédia para as LS. O conteúdo apresentado no Enciclolibras, como modelo da proposta, é o corpo humano. Para o desenvolvimento deste material foi necessária a criação de sinais-termo para as partes do corpo humano - o material criado é visual e inovador.

Também em 2012, Rejane Lourêdo Barros defendeu a dissertação "Política linguística: a terminologia da Libras como veículo de cultura em concursos públicos". A pesquisa apresenta sinais para concurso público, mais especificamente, sinais da área do Direito Administrativo, com o objetivo de auxiliar candidatos surdos na realização de provas de concurso público.

Daniela Prometi defendeu, em 2013, a dissertação intitulada "Glossário bilíngue da Língua de Sinais Brasileira: criação de sinais dos termos da Música”. A pesquisa de Prometi desenvolve um léxico bilíngue para a musicalização de pessoas surdas. Para isso, foram criados e validados sinais terminológicos para a área da Música.

Em 2014, Gláucio de Castro Júnior defendeu a tese intitulada "Projeto Varlibras". O pesquisador apresenta um banco de dados com sinais terminológicos da LSB nas áreas da Biologia, da Física, da História, da Matemática, do Português e da Química, e apresenta as variantes dos sinais-termo identificadas nas cinco regiões do Brasil.

Em 2015, Saulo Machado Mello de Sousa defendeu a dissertação "Sinais lexicais dos termos cinematográficos: a perspectiva da Língua de Sinais Brasileira no cinema". Nesse estudo, Sousa apresenta os sinais-termo criados para a área da Cinematografia e contribui com a acessibilidade dos surdos ao lazer e à cultura pelos meios de comunicação. 
Em 2016, Eduardo Felipe Felten defendeu a dissertação "Glossário Sistêmico Bilíngue Português-Libras de termos da História do Brasil”. A pesquisa de Felten apresenta sinaistermo de três períodos históricos da História do Brasil: América Portuguesa, Império e República. O modelo de glossário pode ser usado por surdos, não-surdos e tradutores e intérpretes de Libras.

Além disso, há artigos sobre o desenvolvimento de léxicos especializados, bem como uma série de trabalhos dispersos e restritos a pequenos grupos. Há também centenas de vídeos disponíveis na internet sobre terminologias das mais diversas áreas do conhecimento, entretanto, em muitas produções não se conhece a procedência e, portanto, não podem ser consideradas como trabalhos de referência. Isso, obviamente, sem mencionar os trabalhos de organização de terminologia que cada escola, professores e intérpretes fazem individualmente para atender às demandas do ambiente escolar.

\subsubsection{Obras terminológicas das LS no Brasil e no exterior}

Nesta seção, apresentamos algumas obras terminológicas das línguas de sinais em suporte impresso e eletrônico, em especial das línguas ASL e LSB. Mostramos também obras terminológicas na Língua de Sinais Britânica (BSL), na Língua de Sinais Venezuelana (LSV) e na Língua Gestual Portuguesa (LGP).

O Dictionary of Sign Language Terms de T. J. Publishers (1980) contém 317 termos religiosos da ASL, organizados em ordem alfabética. Os termos são representados por desenhos e são acompanhados de uma palavra correspondente da Língua Inglesa.

Figura 7 - Sinal ANGEL 'anjo' em ASL

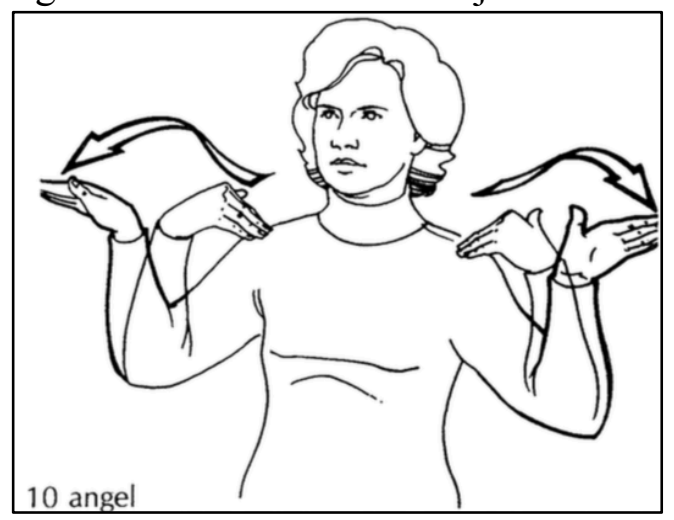

Fonte: Terrence (1980, p. s/n) 
O livro Signs for Science and Mathematics: A Resource Book for Teachers and Students, de Cacamise e Lang (2000), está dividido por áreas terminológicas: a primeira terminologia científica apresentada foi denominada geral; em seguida, o livro apresenta a terminologia da Biologia, depois da Física e por último da Matemática. Os sinais são apresentados também em desenhos com o correspondente em Inglês.

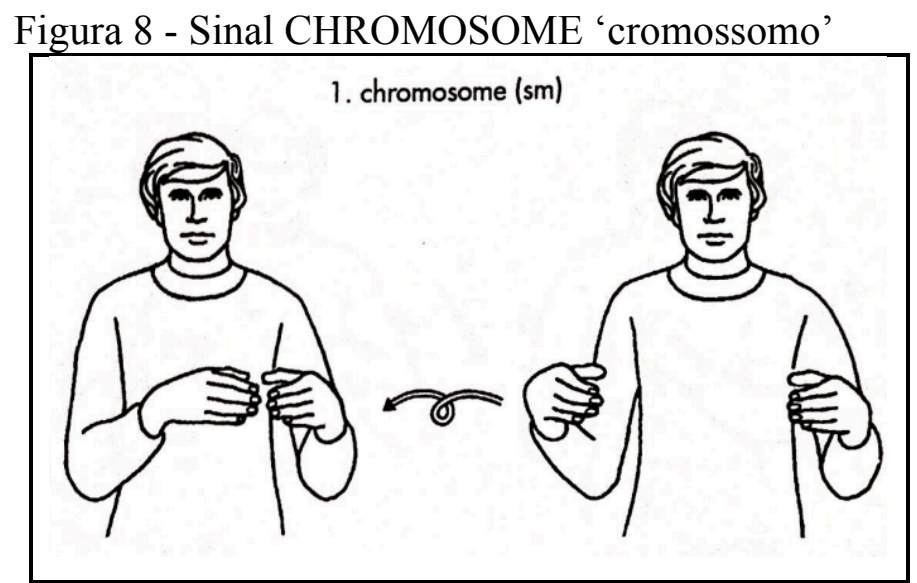

Fonte: Cacamise e Lang (2000, p. 102)

Alguns dicionários e livros da ASL, dedicados a compilar as linguagens de especialidade, são o House Webster's American Sign Language Medical Dictionary (2000) com termos da área Médica, o House Webster's American Sign Language Computer Dictionary (2001) com termos da área da Informática e o House Webster's American Sign Language Legal Dictionary (2003) com termos da área do Direito. Todos os três são produtos oriundos de uma mesma série de livros e da mesma autora Elaine Costelo. Os dicionários são organizados em ordem alfabética e os sinais representados por meio de desenhos e glosas em Língua Inglesa. 
Figura 9 - Estrutura dos verbetes do Glossário do Senai

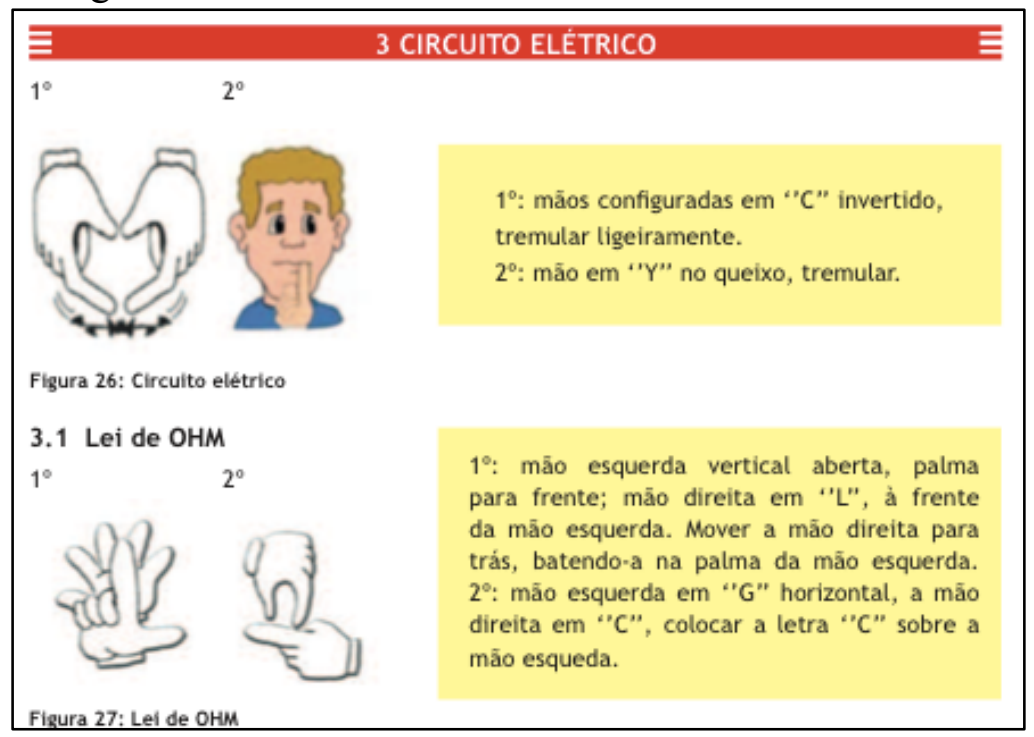

Fonte: Pereira Filho (2011, p.23)

O "Glossário de termos técnicos em Libras: Eletrotécnica do Senai” (2011) é uma obra organizada por temas. A estrutura dos verbetes é composta pela ilustração do sinal por meio de desenhos. Embaixo da ilustração, aparece o número da figura e o termo correspondente em LP. Ao lado de cada verbete, há um retângulo amarelo com a explicação de como o sinal é realizado.

Em suporte eletrônico, DVD, existe a publicação Signs of Sexual behavior: an introduction to sex-related vocabulary in American Sign Language de T.J. Publishers. Esse material foi criado para acompanhar o livro impresso Signs of Sexual Behavior de James Woodward de 1979. O material apresenta um vocabulário sobre o comportamento sexual.

Outro DVD com termos especializados da mesma autoria é o Signs of Drug use: an introduction to drug and alcohol vocabulary in American Sign Language de T.J. Publishers. O material também foi elaborado para acompanhar um livro, neste caso, o Signs of Drug Use, também de James Woodward, em 1980. Essas obras possuem filmes que podem ser vistos por dois ângulos diferentes simultaneamente, um frontal e o outro lateral. Antes da execução do sinal, a palavra em Inglês é projetada e antes de iniciar o sinal, a legenda some, o sinal é realizado duas vezes e, depois, segue para o próximo.

Chama nossa atenção que esses materiais apresentam sinais variantes, quando há, e são organizados em temas para facilitar a busca de determinado sinal. Isso porque são vídeos e, se o usuário não tiver o livro que motivou a criação do DVD, terá de assistir à sequência completa até encontrar o sinal desejado. Sobre a filmagem, os dois ângulos de filmagem são 
interessantes como estratégia para a percepção de detalhes na execução do sinal que, por vezes, não pode ser visto apenas pelo ângulo frontal.

Há as obras terminológicas eletrônicas disponíveis como sites da internet, quais sejam, o ASL-STEM Forum, o Glossário SSC da BSL, o Dicionário Terminológico em LGP, o Glosario Ciencia en Señas, o Dicionário de Libras - Palavras e Termos da Biologia e o Glossário Libras da UFSC.

Figura 10 - Site ASL-STEM

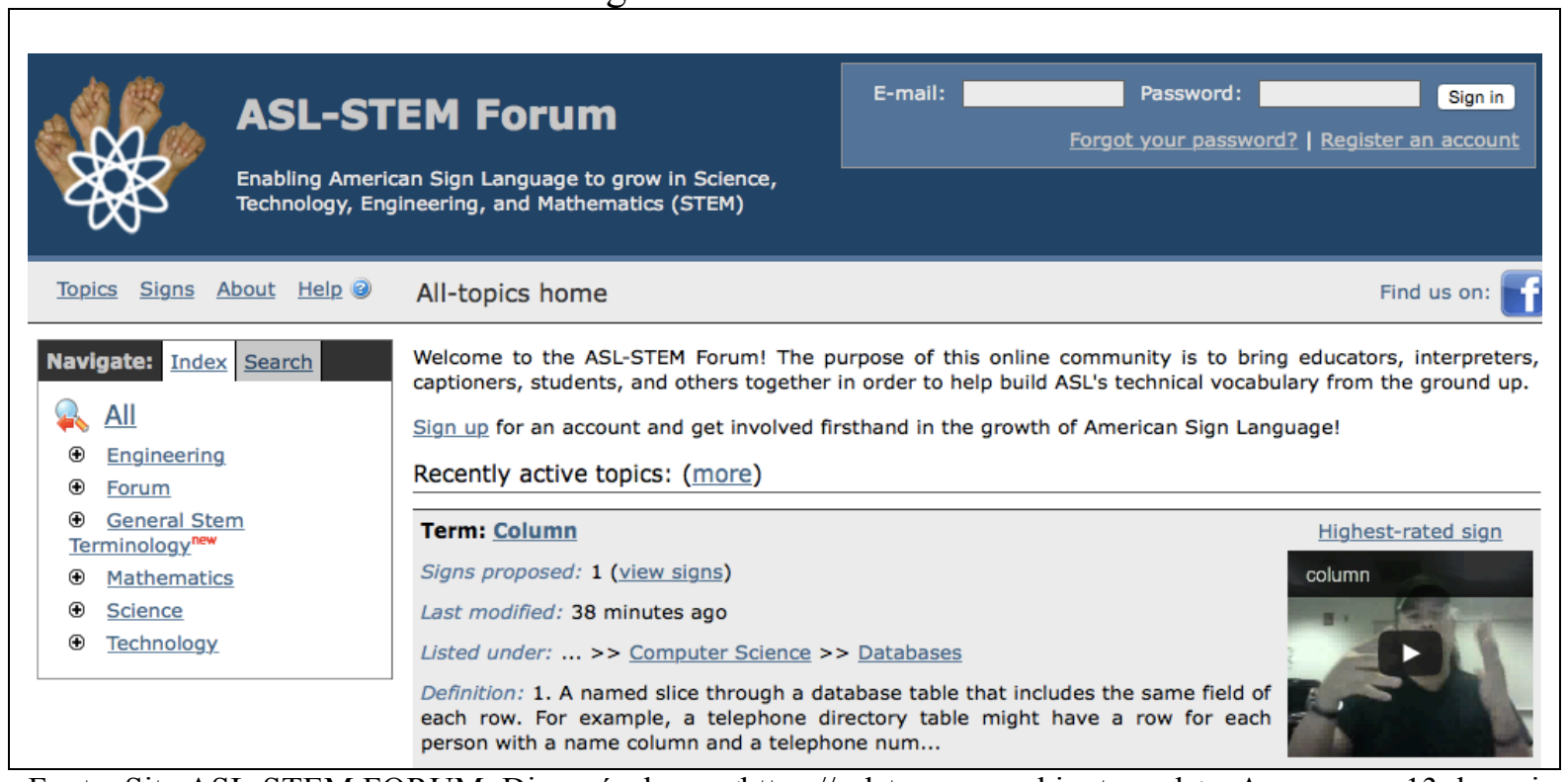

Fonte: Site ASL-STEM FORUM. Disponível em: <https://aslstem.cs.washington.edu>. Acesso em: 13 de mai. 2015.

O site “ASL-STEM Forum” é um ambiente criado pela Universidade de Washington, D.C., EUA e o conteúdo está disponível em https://aslstem.cs.washington.edu. A sigla STEM significa Science 'Ciência', Technology 'Tecnologia', Engineering 'Engenharia' e Mathematics 'Matemática' e representa as letras inicias de cada uma destas áreas. Uma das participantes desse projeto é a Dra. Caroline Solomon, professora de Biologia da Gallaudet. O ASL-STEM Forum tem um mecanismo de busca denominado "Search" para identificar se um determinado termo das mencionadas áreas já está cadastrado. Ao escrever o termo completo, ou parcialmente, aparecem os termos que possuem parte da palavra ou a palavra completa em uma janela abaixo do campo de digitação da pesquisa. Ao clicar no termo desejado, que se encontra em Inglês, caso exista o sinal em ASL, o site nos conduz a um vídeo postado no youtube e apresenta um filme com a execução do sinal. Em alguns termos, há também a definição em ASL. Entretanto, por vezes existe o termo em Inglês, mas não há vídeo algum com o termo ou a definição em ASL - apenas apresenta a definição em Inglês. 
Figura 11 - Sinal FOOD CHAIN 'cadeia alimentar'

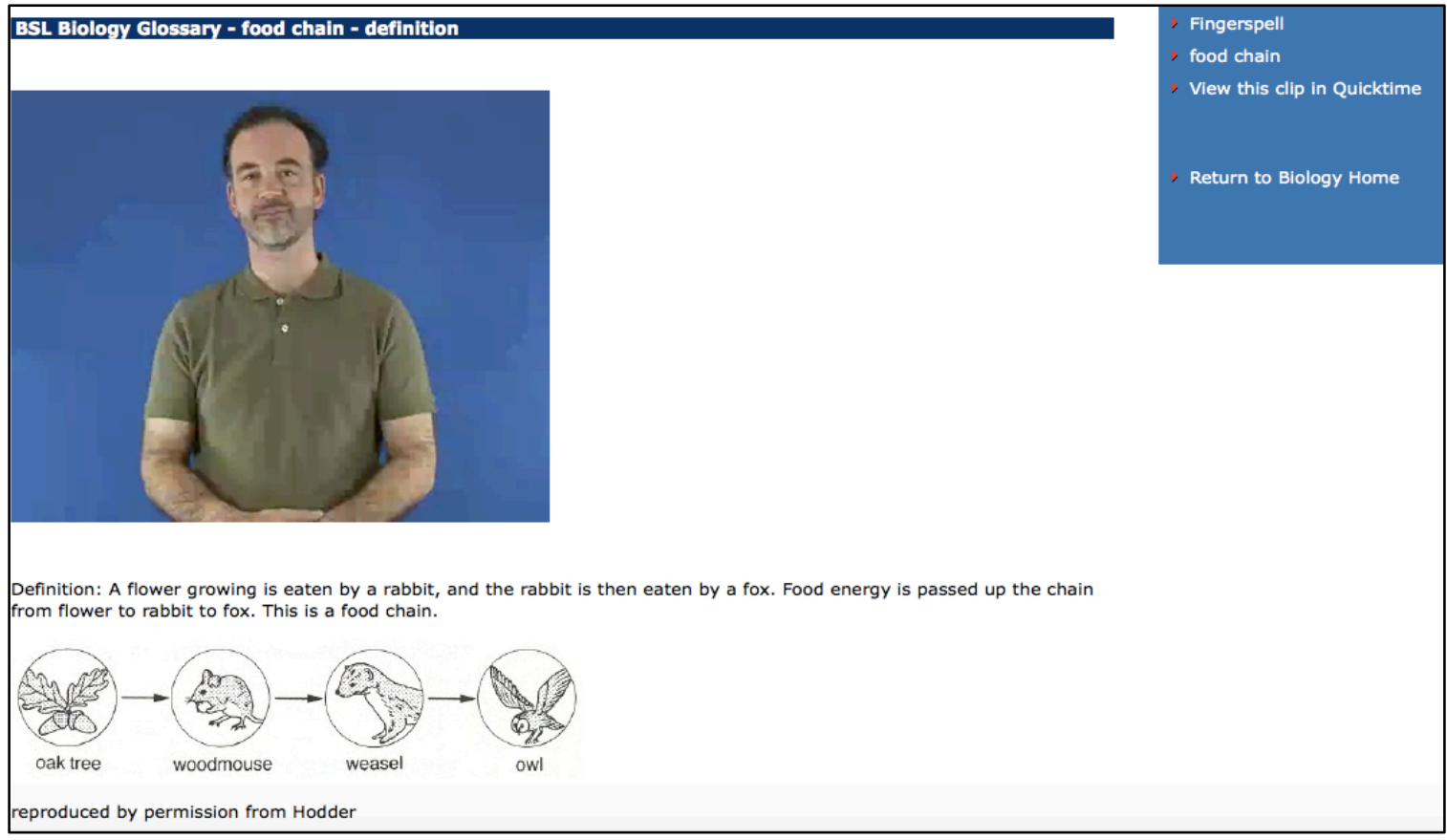

Fonte: Site do Glossário do Scottish Sensory Centre. Disponível em: $<$ http://www.ssc.education.ed.ac.uk/bsl/about.html $>$. Acesso em: 5 nov. 2015.

A Língua de Sinais Britânica (BSL), disponível em http://www.ssc.education.ed.ac.uk/bsl/about.html, também tem um site no esforço de criar e divulgar terminologias científicas em LS. O Glossário do Scottish Sensory Center (SSC) da BSL é um material de termos específicos desta língua.

Os verbetes são organizados em ordem alfabética pelo termo em Inglês e contêm o sinal correspondente gravado em vídeo. Às vezes, a forma datilológica é mostrada também. Diversas entradas possuem um vídeo, explicando em BSL o significado do termo ou apresentam um exemplo de como o termo pode ser usado em BSL. Além disso, há traduções em Inglês das explicações ou exemplos. Há também alguns recursos visuais, como ilustrações - por meio de desenhos ou fotos - e outros recursos visuais como o usado no verbete jawbone 'osso maxilar', em que o ator surdo explica o significado do termo usando um esqueleto. Outra ferramenta que pode ser encontrada em alguns verbetes é o link para entrar em termos correlatos. Serve de exemplo o verbete micro-organism, 'micro-organismo', que apresenta os termos bacteria 'bactéria', microbe 'micróbio' e virus 'vírus', como termos relacionados à entrada micro-organism. Também há a opção de fazer o download do vídeo com o sinal e com as explicações do significado ou exemplos. 
A equipe desse projeto de Glossário da BSL conta com um grupo forte de cientistas e matemáticos surdos que colaboram com a coleta e com o desenvolvimento das terminologias. O projeto tem glossários nas áreas de Astronomia, Biologia, Química, Matemática e Física.

Figura 12 - Site do Glosario Ciencia en Señas da LSV

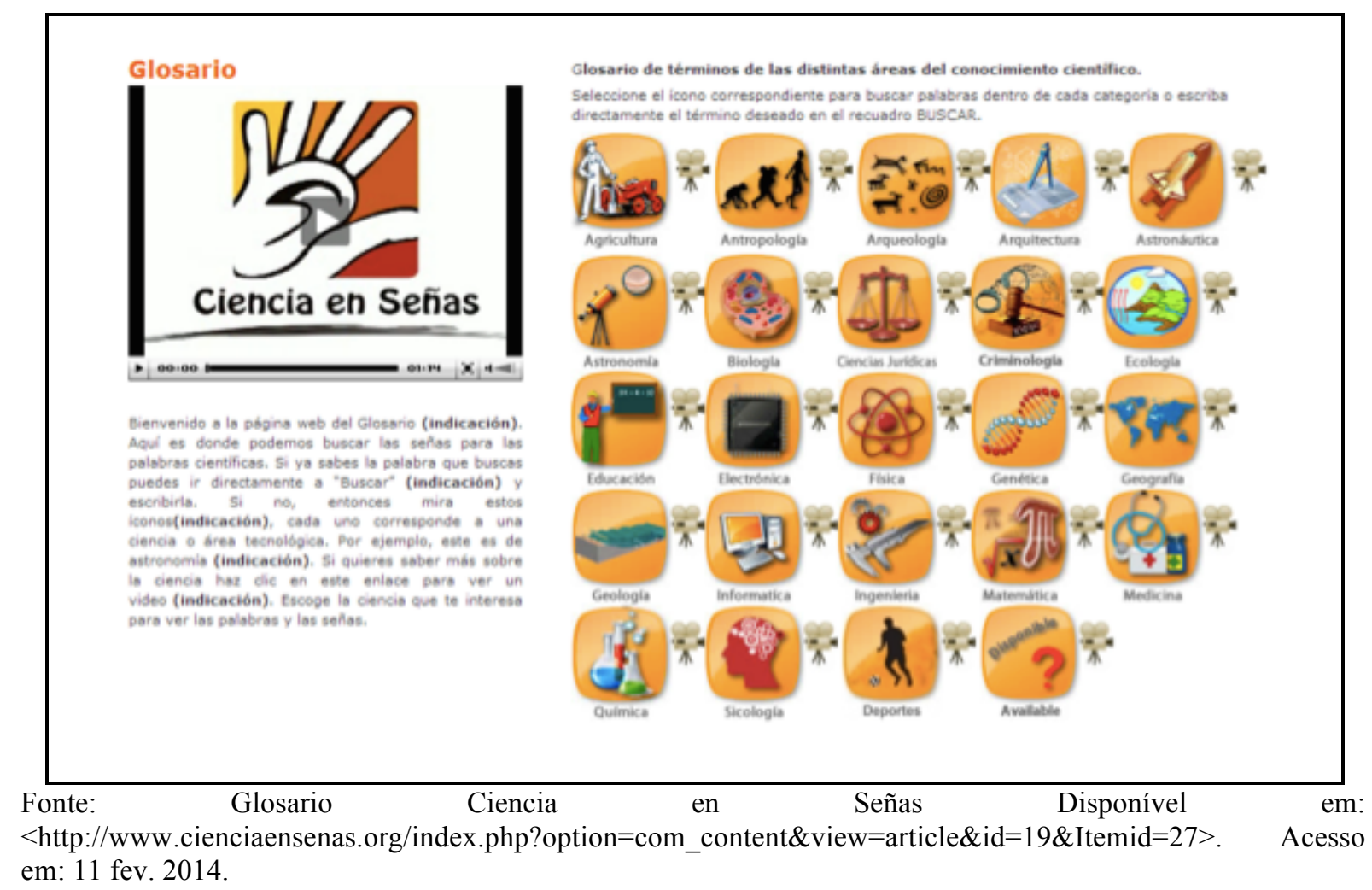

O Glosario Ciencia en Señas da Língua de Sinais Venezuela (LSV) é composto pelas seguintes áreas: Agricultura, Antropologia, Arqueologia, Arquitetura, Astronaútica, Astronomia, Biologia, Ciências Jurídicas, Criminologia, Ecologia, Educação, Eletrônica, Física, Genética, Geografia, Geologia, Informática, Engenharia, Matemática, Medicina, Química, Psicologia e Esportes, como podemos observar na figura 12. O consulente clica na área do conhecimento desejado e acessa os termos. 
Figura 13 - Verbete da entrada "artigo definido" da LGP

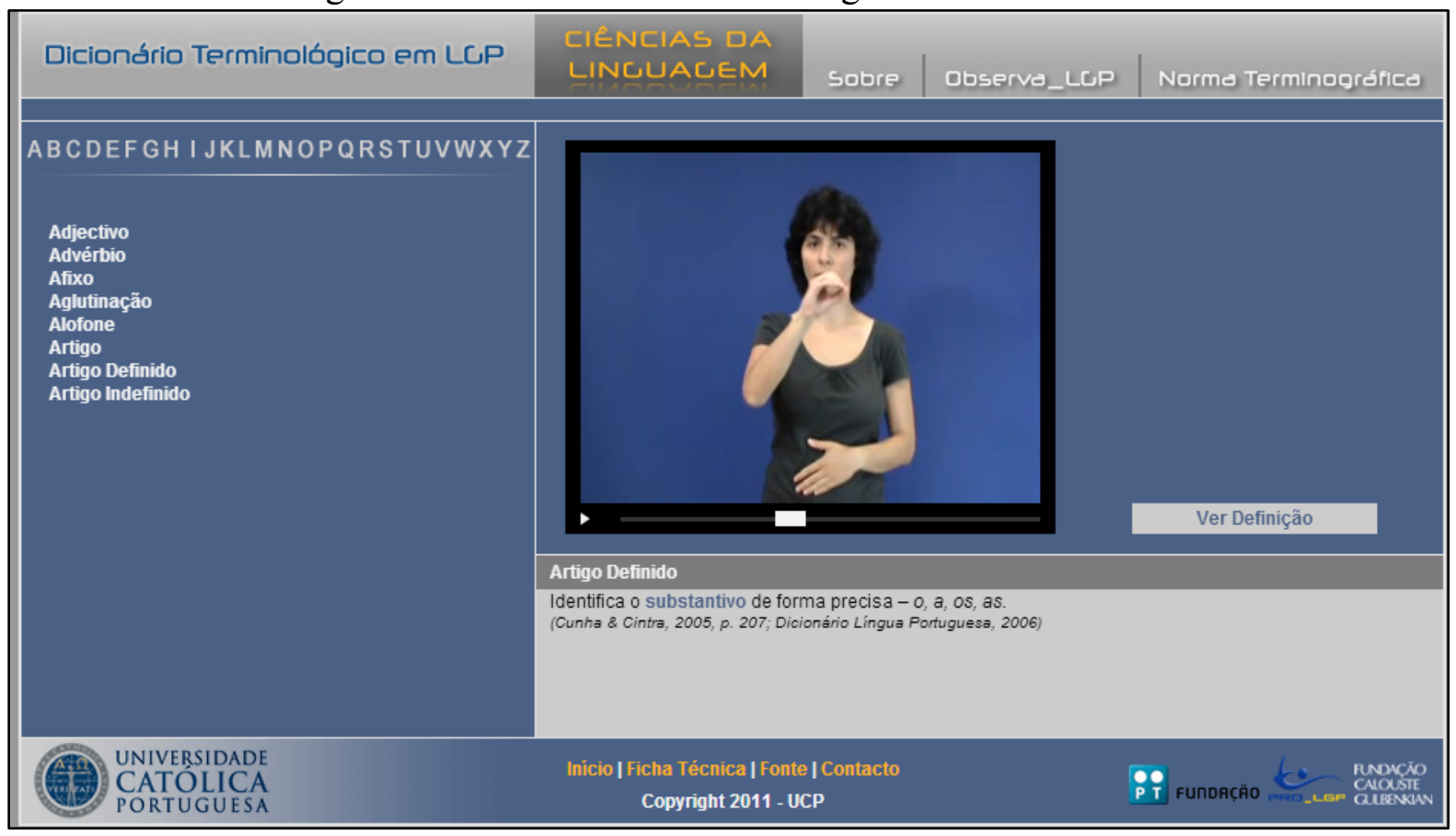

Fonte: Dicionário Terminológico em LGP. Disponível em:< http://pro-lgp.com/dicionario/ >. Acesso em: 26 out. 2015.

O "Dicionário Terminológico em LGP” é um projeto da Universidade Católica Portuguesa e foi pensado para o curso de Licenciatura em Língua Gestual Portuguesa (PROLGP). É uma obra online, disponível em http://pro-lgp.com/dicionario/ e contém sinais das áreas da Linguística, Neurociências e Ciências da Educação. O dicionário é organizado em ordem alfabética pela Língua Portuguesa e a busca pelo termo também é apenas por meio desta língua. A estrutura do verbete é composta pela entrada em LP, o sinal correspondente filmado, definição em LP e em LGP. Um modelo de verbete é mostrado na figura 13. Quando existe mais de uma acepção para cada sinal, esses estão numerados. Caso o sinal seja diferente para cada acepção, optam por uma entrada homônima em LP com os sinais diferentes correspondentes. Ademais, relacionam os termos sinônimos, antônimos e superordenados, e há um sistema de remissão interna no verbete.

Assim como no dicionário da LGP, as terminologias de nossa pesquisa também são propostas terminológicas. A intenção é que os surdos usem, questionem, critiquem, validem e aperfeiçoem os termos e a ferramenta para as necessidades deles. 
Figura 14 - Sinal ECOLOGIA

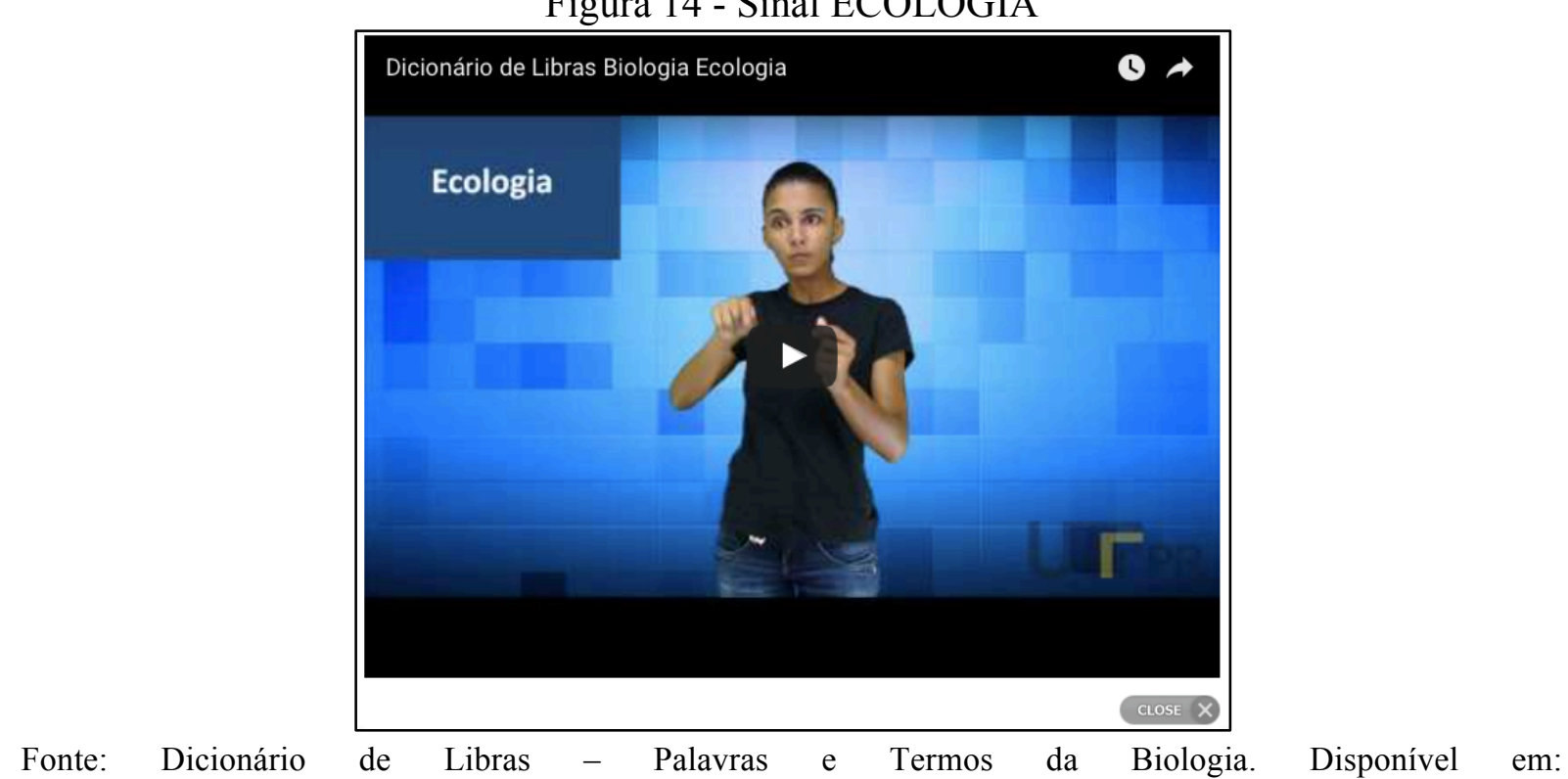

$<$ http://epeem.cp.utfpr.edu.br/site/?page_id=8.>. Acesso em: 1 set. 2015.

O "Dicionário de Libras - Palavras e Termos da Biologia" da Universidade Tecnológica Federal do Paraná (UTFPR) é um site com uma lista de termos da Biologia organizado em ordem alfabética e encontra-se disponível em http://epeem.cp.utfpr.edu.br/site/?page_id=8. O sistema de busca ocorre na Língua Portuguesa e, para isso, deve-se clicar no termo desejado. Em seguida, uma janela com um vídeo do sinal é aberta, como mostra a figura 14. Todavia, diversos vídeos apresentam uma explicação do significado do termo e não uma proposta de sinal terminológico.

O Glossário de Libras da UFSC (figura 15) é uma obra lexicográfica relevante para a LSB, não só pela tecnologia usada, como também pela funcionalidade da obra. $\mathrm{O}$ site apresenta glossários de três áreas: Letras Libras, Arquitetura e Cinema, e está disponível em http://www.glossario.libras.ufsc.br

O material tem três opções de busca: pelo sinal, pelo Português e pelo Inglês. A busca pelo sinal pode ser realizada por meio dos parâmetros configuração de mão e locação. Contudo, a forma de como usar a busca pelo sinal não está explícita no glossário. Mesmo não sendo explícita ao consulente, existe um link denominado "como buscar", criado especificamente para isso, mas que não está disponível para visualização.

A microestrutura do verbete é composta pelo sinal, pela definição em LSB e exemplo de uso do sinal e suas variações, esta última, quando houver. Ademais, é mostrado no verbete o termo em LP e em Inglês. Apresenta também as configurações de mão, a locação do sinal e o termo escrito em signwriting. Cada entrada possui quatro vídeos: um com o sinal, outro com 
a explicação do conceito, um com os exemplos de frases de como usar o sinal e mais outro com variantes do sinal.

Figura 15 - Verbete do sinal CONECTIVO do Glossário do Letras Libras da UFSC

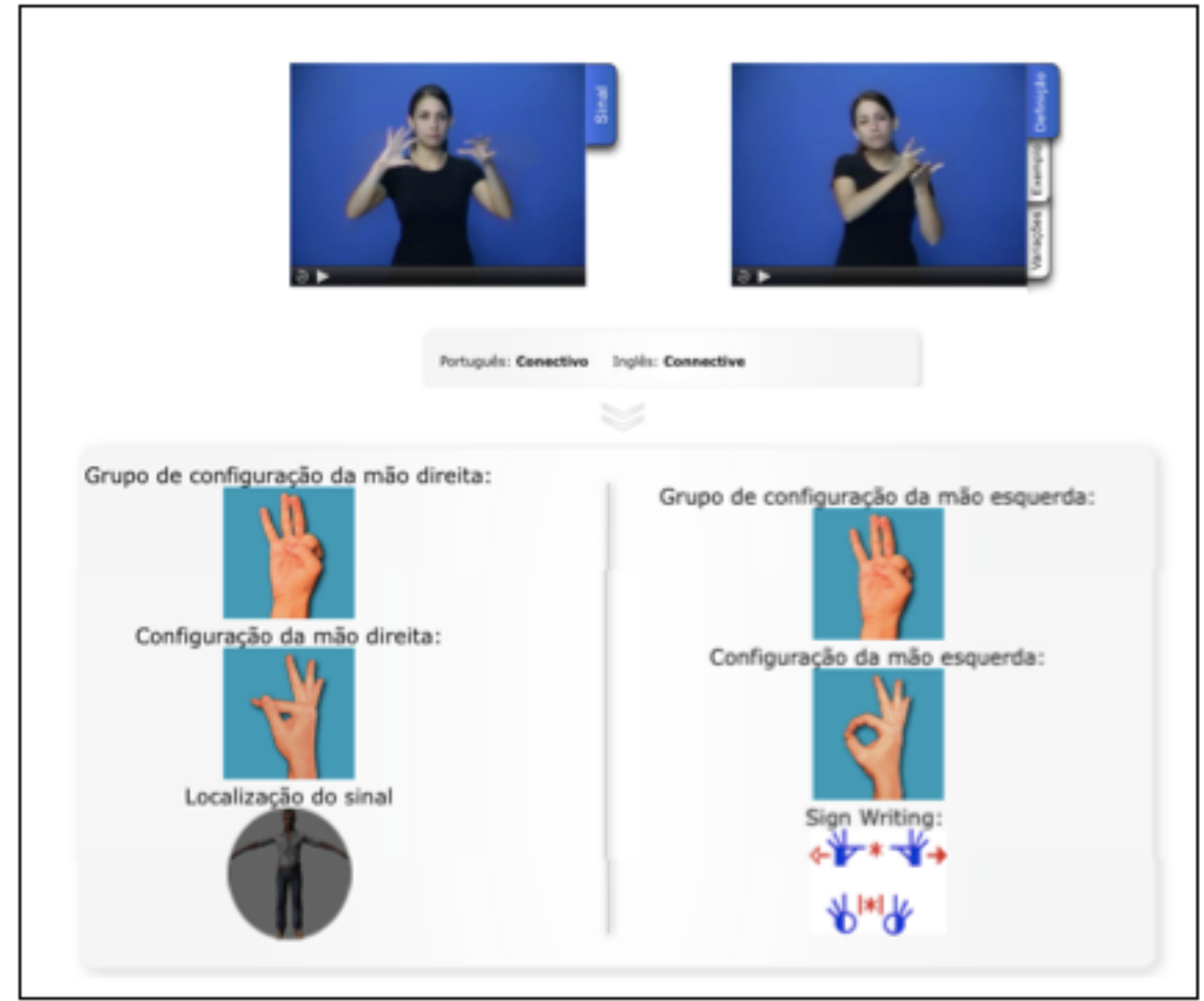

Fonte: Glossário de Libras da UFSC. Disponível em: < http://www.glossario.libras.ufsc.br >. Acesso em: 20 de dez 2015.

Na próxima seção, a lexicografia é o centro. Apresentamos discussões e análises de obras lexicográficas e terminológicas das LS, a fim de chegarmos a uma proposta de glossário que atenda com eficácia ao público-alvo, e que seja mais adequada para registrar uma língua sinalizada.

\subsection{Lexicografia}

A Lexicografia é a ciência que estuda a teoria e a prática de elaboração de dicionários. Nesta pesquisa, atemo-nos aos temas sobre Lexicografia que contribuem para as decisões de nossa proposta de glossário ilustrado semibilíngue, em mídia digital. Para isso, apresentamos 
nossa compreensão do que é glossário e como compreendemos uma obra semibilíngue; refletimos a respeito das ilustrações nos dicionários das LOs e das LS; seguimos com um breve histórico dos primeiros registros das línguas de sinais no mundo e da Lexicografia da LSB; discutimos as características da Lexicografia das LS impressas e eletrônicas, bem como, a definição terminológica no âmbito da Lexicografia para surdos.

Existe uma compreensão muito diversificada do que seja glossário em Lexicografia. Todavia, esta é outra discussão que não faz parte do escopo de nossa pesquisa e, portanto, apenas expomos a compreensão de glossário que adotamos. Nesta tese, compreendemos glossário como em Faulstich (2010, p. 178): é um “conjunto de termos, normalmente de uma área, apresentados em ordem sistêmica ou em ordem alfabética, seguidos de informação gramatical, definição, remissivas, podendo apresentar ou não o contexto de ocorrência do termo". A autora esclarece ainda, que "o glossário é um documento terminográfico objetivo, dirigido a usuários específicos que procuram informações lexicais e semânticas precisas, com vistas a melhorar o desempenho linguístico e a aperfeiçoar o conhecimento profissional" (FAULSTICH, 2010, p. 178).

A partir desse entendimento do que seja glossário, apresentamos outro conceito - o de semibilíngue - que se faz necessário esclarecer. Este tipo de obra lexicográfica tem sido encontrada na literatura com denominações variadas, como dicionário híbrido, bilingualizado, traduzido, glossed, entre outros. Vale observar que não é objetivo de nossa pesquisa discutir a melhor terminologia para este tipo de dicionário, todavia, é válido mencionar que há divergências no entendimento do que venha a ser uma obra semibilíngue.

Nesta pesquisa, compreendemos o termo semibilíngue como explica Duran e Xatara (2005, p. 49), uma obra lexicográfica cuja principal característica consiste em exibir a entrada e metalinguagem, definições e exemplos, em língua estrangeira e a língua materna aparece apenas nos equivalentes. No caso do nosso público-alvo, as informações gramaticais, definições, metalinguagem, estão em uma segunda língua e a primeira língua dos surdos, a LSB, é contemplada com os sinais-termo da área do Meio Ambiente, todavia não há definição em LSB. Tendo em vista essas características, concluímos que a nossa proposta é semibilíngue.

Ainda sobre obras semibilíngues, Faulstich (2006) esclarece que "a principal diferença do dicionário bilíngue para o semibilíngue está na composição da microestrutura em que se elabora o verbete na língua de aprendizagem". Nesta perspectiva do semibilíngue, para o nosso caso, a LP é a língua de aprendizagem. 
Carvalho e Marinho (2007, p. 122) consideram que o dicionário semibilíngue é uma categoria pertinente para desenvolver obras lexicográficas da LSB, porque além de contemplar o usuário quanto à segunda língua que está aprendendo, ainda apresentam a primeira língua dos surdos.

A partir desses entendimentos de glossário e de obra lexicográfica semibilíngue, discutimos temas que contribuíram para a tomada de decisões das características e das informações que constam da nossa proposta lexicográfica. Concebemos a criação de uma obra lexicográfica, assim como em Silva (2006, p. 13):

a construção de um dicionário... não se resume à compilação de dados préexistentes. Ao contrário, é uma atividade que abrange um conjunto de decisões e de procedimentos que incidem sobre a organização da macro e da microestrutura da obra, de acordo com o fim a que ela se destina.

Nessa perspectiva, fazer um dicionário envolve a construção, a criação e a adaptação de conteúdos para maior eficácia da obra ao público-alvo, sendo assim, uma tarefa muito mais complexa do que a compilação de obras já existentes.

\subsection{Ilustração em obras lexicográficas}

Existe uma crença de que apenas obras infantis devem conter ilustrações. É notável nos livros que quanto mais idade tem o leitor, menor é a probabilidade de encontrar ilustrações nesses materiais. Nos dicionários, essa concepção de que ilustração é uma característica de obras destinadas a crianças também está explícita.

As ilustrações em obras lexicográficas têm sido adotadas tanto por razões comerciais quanto por motivos pedagógicos. Muitas vezes, as informações por meio de ilustração funcionam mais como um elemento de atração e ludicidade do que propriamente um conteúdo informativo.

O mau uso desses recursos visuais tem gerado estudos críticos como o de Silva (2006), em relação à presença de ilustrações nos dicionários. Com base na teoria da Multimodalidade, Silva (2006) apresenta um estudo sobre as ilustrações nos dicionários infantis. A autora analisa se a ilustração e o texto verbal são elementos que se complementam e, consequentemente, facilitam a compreensão do lema, entrada. $\mathrm{O}$ estudo mostra que a maioria dos autores dos dicionários infantis considera o conteúdo visual mais do que 
ornamentos, em outras palavras, são recursos funcionais que contribuem para a elucidação de um conceito.

Entretanto, muitas ilustrações são apenas ornamentos e apresentam problemas como inadequação e falta de precisão dos conceitos - que geram interpretações ambíguas e imprecisas -; falta de fidelidade na reprodução da realidade com a omissão de informações e a falsidade na informação visual; apresentação desnecessária de ator que mostra uma ação não pedida pelo lema (dessa forma, o autor é salientado em detrimento do lema); e pouca utilização de suporte verbal para as imagens, imagens que apresentam grande complexidade de leitura, imagens que se distanciam do que está expresso verbalmente, imagens que veiculam informações enciclopédicas, imagens contraditórias, pois nenhuma das acepções se relacionam com a imagem vinculada. Silva (2006) sugere que as ilustrações recebam um tratamento sistematizado e coerente, com o estabelecimento de critérios para a representação visual.

Para Farias (2013, p. 301), "uma ilustração é funcional quando complementa ou substitui uma "paráfrase opaca propriamente dita". Ela organiza os critérios para que uma ilustração possa ser considerada um mecanismo explanatório elucidativo e esclarece que a ilustração deve estabelecer uma relação direta com o referente ao qual a designação em questão se aplica; ser de boa qualidade, o que implica uma boa resolução da imagem e, em muitos casos, o uso de cores; o dicionário deve estabelecer uma rede de referências entre as ilustrações e a microestrutura.

Quanto ao estabelecimento dessa relação ilustração/microestrutura, Silva (2006, p. 60) explica que essa ligação deve ser clara. Isto porque em obras impressas a ilustração pode estar em uma página diferente do verbete a que se refere. Todavia, a relação verbete/ilustração é mais facilmente resolvida pela lexicografia eletrônica. Além de ser mais barata, permite uma relação mais clara com o verbete. Silva ainda explica que a consulta da ilustração deve permitir a direção: lema - definição - ilustração e a direção: ilustração - lema - definição. Na proposta do nosso glossário, a ilustração tanto é parte da microestrutura do verbete quanto é mecanismo de busca. Dessa forma, o glossário permite as duas direções mencionadas de relacionamento entre a parte verbal e visual.

Como dissemos, as ilustrações são recursos mais comuns em dicionários infantis. No entanto, por ser uma língua de natureza visual, a ilustração é uma ferramenta comum nas obras lexicográficas que contém uma língua de sinais.

Grande parte dos dicionários de LS possui ilustração que, em geral, é a tentativa de representar a execução dos sinais. Em algumas obras, há também a ilustração como tentativa 
de expressar o significado referente aos sinais. Sofiato (2005) apresenta uma discussão crítica de como os sinais das LS são apresentados nas obras. Na ocasião, ela não analisou apenas obras lexicográficas. Entretanto, as representações encontradas nos diversos materiais são reflexos das concepções que se tem de lexicografia, que envolvem as mais diversas línguas de sinais.

Na lexicografia das LS, as ilustrações podem ser dos sinais e dos significados dos sinais. E os problemas acabam ocorrendo nesses dois tipos de representação, tanto do sinal da língua - que não se consegue passar toda a complexidade dos movimentos e das expressões não manuais para o papel -, quanto dos significados contidos nos sinais. Além disso, surgem as mesmas dificuldades relatadas pelos pesquisadores que analisam ilustrações em dicionários em que a ilustração não permite uma referência direta com o referente, entre outros problemas já mencionados.

Nas ilustrações de dicionários de LS, por exemplo, o uso de recursos gráficos é abundante e são usados para tentar expressar os movimentos e expressões não manuais inerentes a essas línguas. Por isso, o ilustrador ou o fotógrafo de obras lexicográficas de LS precisam conhecer a língua para representá-la de forma adequada, conforme Sofiato e Reily (2014, p. 122) advertem.

Sofiato e Reily (2014) apresentaram uma análise de dicionários impressos da LSB e tratam das dificuldades de apreensão das imagens nesse tipo de obra. Para elas, "os dicionários de Libras se diferenciam dos dicionários de línguas orais por serem quase em sua totalidade ilustrados". As autoras aconselham que as ilustrações sejam reproduções mais reais possíveis e que precisam contar com revisores e autores surdos.

As ilustrações, se feitas com boa qualidade, podem contribuir para a elucidação dos significados. Deste modo, podem ser ferramentas complementares ou até mesmo alternativas do significado. Com as novas tecnologias, as ilustrações também podem ser modernizadas e melhor representadas com o uso de movimentos na lexicografia eletrônica ou mesmo na impressa, pode-se estabelecer critérios padrões de representação visual, com uso de setas, legendas e outros recursos visuais.

As ilustrações na nossa proposta, além de contribuir para a compreensão do conceito, têm a função de estimular a visualidade dos surdos. O estímulo visual para surdos é um importante elemento na apreensão de novos conceitos e pode auxiliar muito na compreensão do mundo. Obviamente, trabalhar com imagens também pode ser um caminho perigoso, já que podemos apresentar determinados conceitos estereotipados ou com ideologias 
indesejadas. De todo modo, acreditamos que as ilustrações podem contribuir com o entendimento da LP e dos conceitos científicos.

Apresentamos, a seguir, fragmentos de textos que mostram como as imagens são importantes para os surdos e contribuem para a interação e o entendimento do mundo por meio da visualidade.

Observemos alguns excertos do livro da atriz Surda Emmanuelle Laborit (1994):

Tinha meus barulhos pessoais, inexplicáveis para quem escuta. Tenho minha imaginação, e ela tem seus barulhos em imagens. Imagino sons em cores. Meu silêncio tem, para mim, cores, nunca é preto ou branco (p. 19)... Até a idade de sete anos, nada de palavras, nenhuma frase em minha cabeça. Imagens somente (p. 22)... Minha memória visual associa-se perfeitamente à ortografia francesa. Uma palavra é uma imagem, um símbolo...Posso reconhecer a cara de uma palavra! E desenhá-la no espaço! (p. 164)

Outro livro que trata da visualidade dos surdos é o de Sacks (1998) ao apresentar um relato sobre Joseph, um menino surdo de 11 anos que tinha acabado de entrar em uma escola de surdos e que, mesmo privado de ter uma língua, demonstrava suas habilidades visuais:

Sua inteligência visual - a habilidade de resolver quebra-cabeças e problemas visuais - era boa, contrastando radicalmente com suas imensas dificuldades com os problemas de base verbal. Ele sabia desenhar e gostava dessa atividade: fazia bons esboços do quarto, apreciava desenhar pessoas; "entendia" desenhos animados, "entendia" conceitos visuais. (SACKS, 1998, p. 51)

A tese de Campelo $(2008$, p. 40) também deixa clara a importância dos estímulos visuais, inclusive para aprender a Língua Portuguesa:

Para reforçar o acesso à Língua Portuguesa, meu pai começou a me levar aos cinemas, desde os cinco anos. Foi um "amor visual" à primeira vista, perfeito para o meu pensamento visual. Alguns filmes eram legendados e outros não, mas para mim isso não importava. $O$ que me importava era aprofundar as performances e competências que atiçavam muitas imaginações e construções de signos visuais.

Todos esses relatos deixam clara a importância da visualidade na vida dos surdos e sua importância para a aprendizagem. Em razão da visualidade das pessoas surdas, propomos a ilustração como uma das vias de acesso às entradas do glossário. Isto se deve, principalmente, às singularidades do público-alvo que, em geral, apresenta uma percepção visual mais aguçada. Os surdos, muitas vezes, têm uma imagem mental de determinado objeto, mas não 
conhecem a palavra em LP. Por isso, a busca pela ilustração para se chegar ao lema pode ser um caminho de lexicografia para os surdos com vista ao aprendizado do Português como segunda língua.

\subsection{Lexicografia das Línguas de Sinais}

As obras lexicográficas das LS também vêm recebendo denominações como Sinalário, nomeado por Stumpf ${ }^{34}$, Manuário de Favorito, Repertório lexicográfico, conforme FariaNascimento (2009) e Gestuário na LGP.

Para Sofiato e Reily (2014, p. 119), a lexicografia da LSB tem as seguintes características: a maioria dos verbetes dos dicionários não apresentam acepções, usos, derivações e classificação gramatical.

Nesta tradição da lexicografia das línguas de sinais, têm sido criados "dicionários" que são apenas listas de palavras bilíngues. A maioria dos materiais contém um conjunto de palavras escritas da língua oral e possui um desenho ou uma foto do sinal correspondente à palavra da LO, como mencionado por Johnston (2003 apud Zwiterlood, 2010, p. 445).

Além disso, Zwiterlood (2010, p. 445) explica que os dicionários de LS, geralmente, não fornecem mais que uma tradução do sinal por palavra, isto é, fazem a associação de uma palavra para um sinal, são unidirecionais (da LO para LS), a organização é alfabética ou temática (ou ainda ambas simultaneamente), são impressos e bilíngues - no sentido de ter a presença de duas línguas, não na funcionalidade do dicionário.

Para compreender melhor a lexicografia das LS, apresentamos o histórico dos registros das Línguas de Sinais. Martins, Ferreira e Mineiro (2012, p. 29-38) apresentam um histórico dos primeiros registros em papel de língua de sinais e mostram os trabalhos precursores nessas línguas.

O primeiro documento em papel com conteúdo da comunicação dos surdos é o livro do ano de 1620 intitulado Reduction de las Letras y Artes para Enseñar Ablar los Mudos 'Redução das letras e arte para ensinar os mudos a falar'. Esta obra apresenta, pela primeira vez, um alfabeto manual. Em 1644, John Bulwer publicou a obra Chirologia or the Natural Language of the hand 'Quirologia ou a linguagem natural da mão' e em 1648, o mesmo autor publicou Chironomia 'Quironomia' e Philocophus or the Deaf and Dumb Man's Friend 'O

\footnotetext{
${ }^{34}$ Para Stumpf (2005, p. 36) apud Stumpf et al. (2015, p. 171), sinalário é um "conjunto de expressões que compõem o léxico de uma determinada língua de sinais".
} 
amigo do homem surdo e mudo’ onde foram apresentados alguns sinais. Já em 1669, William Holder escreveu o livro Elements of Speech: An Essay of Inquiry into The Natural Production of Letters: with an Appendix Concerning Persons Deaf \& Dumb 'Elementos da fala: um trabalho de pesquisa sobre a produção natural das letras: com um apêndice sobre as pessoas surdas e mudas'.

Em 1806, Gilbert Austin escreveu o livro Chironomia or a treatise on rhetorial delivery 'Quironomia ou um tratado sobre o discurso retórico'. Abade Jean Ferrand (1731 1815) escreveu, anonimamente, o primeiro Dictionnaire des Sourds-Muets Dicionário dos surdos-mudos', os sinais na obra são descritos e não desenhados, por ser uma obra anônima, não se sabe a data de publicação. Outro abade, em 1808, Roch-Ambroise Sicard, escreveu Théorie des signes ou introduction à l'étude des langues, où le sens des mots au lieu d'être défini, est mis en action 'Teoria dos sinais ou introdução ao estudo das línguas, onde o sentido das palavras em vez de ser definido, é posto em ação'. Sicard ficou conhecido como o primeiro autor do dicionário da Língua de Sinais Francesa, apesar de não ser proficiente o bastante nesta língua.

Em 1825, Roch-Ambroise Bébian publicou o dicionário da LSF intitulado Mimographie 'Mimografia'. Nesta obra, Bébian apresentou pioneiramente um sistema de escrita de sinais onde criou símbolos para os diferentes parâmetros. Dois anos depois, em 1827, Joseph-Marie Degérando escreve o livro De l'éducation des sourds-muets de naissance 'Sobre a educação dos surdos-mudos de nascença' no qual descreve aproximadamente 300 sinais.

Franz Herrmann Czech, em 1838, publica o livro Versinnlichte Denk und Sprachlehre 'Exercícios de visualização mental e oral' que contém imagem dos objetos como complemento dos sinais. Em 1850, Alexandre Blanchet publicou o dicionário da LSF intitulado Dictionnaire usuel de Mimique et de Dactylologie 'Dicionário usual de mímica e datilologia'. Essa obra apresenta a descrição verbal de aproximadamente 700 sinais.

Em 1850, Yves-Léonard-Remi Valade escreveu o livro Études sur la lexicologie et la grammaire du language naturel des signes 'Estudos sobre a lexicologia e a gramática da linguagem natural dos sinais' que opta por desenhos para representar os sinais dos surdos. No ano seguinte, em 1851, Jérôme Antoine Jarish insere a representação dos movimentos nos sinais por meio de setas e ademais introduz as expressões faciais nas ilustrações do seu livro Méthode d'instruction des sourds-muets à la parole, aux mathématiques et à la religion 'Método de instrução dos surdos-mudos à fala, à matemática e à religião'. Neste mesmo ano, Joséphine Brouland publica a obra Tableau specimen d'un dictionnaire des signes 'Quadro 
exemplificativo de um dicionário de sinais' no qual apresenta os desenhos dos sinais com a palavra correspondente na língua oral.

Joseph Piroux seguiu a proposta de Bébian ao representar a língua de sinais por meio de uma escrita com base em símbolos e publicou, em 1856, o livro Méthode de dactylologie, de lecture et d'écriture à l'usage des sourds-muets 'Método de datilologia, leitura e escrita para a utilização dos surdos-mudos'.

Em 1856, Pierre Pélissier, professor surdo, escreveu o livro Une iconographie de signes 'Uma iconografia dos sinais' em que representa os sinais por meio de desenhos e os movimentos com setas. Em 1859, Loius-Marie Lambert publica o livro Le langage de la phisionomie du geste mis a la portée de tous 'A linguagem da fisionomia do sinal posta ao alcance de todos'. E a última obra para concluir o histórico é o dicionário de William Stokoe, Dorothy Casterline e Carl Croneberg em 1965 intitulado A Dictionary of American Sign Language on linguistics principles 'Um Dicionário da Língua de Sinais Americana nos princípios linguísticos'. Esta obra foi inovadora para a época, pois, pela primeira vez, os sinais foram organizados de acordo com a característica dos sinais como a locação, configuração de mão e movimento.

No Brasil, a primeira obra lexicográfica da LSB, a saber, é a Iconografia dos Signaes dos surdos-mudos de Flausino José da Gama (1875), apesar de esta obra ser considerada por Sofiato (2011 apud Sofiato e Reily, 2014, p. 111) uma cópia do livro francês de Pierre Pélissier intitulado Une iconographie des signes que mencionamos anteriormente.

Após a obra de Gama (1875), houve um longo intervalo de tempo para a publicação da obra lexicográfica brasileira seguinte que é o livro "Linguagem das Mãos" de Eugênio Oates em 1969. Sofiato e Reily (2014, p. 111) imputam a ausência de obras lexicográficas na LSB ao Congresso de Milão em 1880, que proibia o uso das LS na educação de surdos.

Em 1981, John Peterson publicou Comunicação total $1^{\text {a }}$ edição do livro “Comunicando com as mãos”. Dois anos depois, em 1983, Harry W. Hoemann, Eugênio Oates e Shirley A. Hoemann publicaram a obra "Linguagem de sinais do Brasil". No ano seguinte, em 1984, Peterson e Ensminger apresentaram o livro "Aprendendo a comunicar" e os mesmos autores, em 1987, publicaram o livro "Comunicando com as mãos".

No ano de 1991, Valdecir Menis e Salomão Dutra Lins publicaram o "Manual de sinais bíblicos: o clamor do silêncio". No ano seguinte, um grupo de Testemunhas de Jeová publicou o livro "Linguagem de sinais". E a última obra mencionada nesse histórico é o "Manual Ilustrado de sinais e sistema de comunicação em rede para surdos" de Capovilla, Raphael e Macedo de 1998. 
Quando observamos esse histórico, é possível ver como a lexicografia da LSB tem se ampliado com a criação de manuais e obras lexicográficas disponíveis no mercado. $\mathrm{O}$ interesse da lexicografia também pode ser notado na academia. As pesquisas sobre lexicografia da LSB vêm sendo realizadas nas universidades brasileiras. Identificamos as seguintes dissertações e teses sobre lexicografia da LSB.

Em 2009, Faria-Nascimento defendeu a tese "Representações lexicais da língua de sinais brasileira: uma proposta lexicográfica". Nesta pesquisa Faria-Nascimento apresenta uma sistematização dos elementos constitutivos do léxico comum e especializado da LSB. Além disso, analisa dicionários das LS e a partir de suas reflexões, propõe uma organização dos parâmetros para o desenvolvimento de obras lexicográficas em LSB. A proposta do parâmetro $\mathrm{CM}$, em que a pesquisadora organiza $75 \mathrm{CMs}$, são úteis para o nosso glossário. Ademais, apresenta dois modelos de obras lexicográficas: o Glossário Didático Visual de Classificadores em LSB e o Glossário Terminológico de Linguística em LSB.

Antonielli Cantarelli Martins, em 2012, defendeu a dissertação intitulada "Lexicografia de Língua de Sinais Brasileira do Rio Grande do Sul”. Martins apresenta um estudo dos sinais usados no Rio Grande do Sul com vista à dicionarização no "Novo DeitLibras: Novo Dicionário Enciclopédico Ilustrado Trilíngue da Língua de Sinais Brasileira”. Esta pesquisa chegou a um corpus de 2.869 sinais da LSB que foram descritos e ilustrados, todavia, apenas uma amostra está disponível na dissertação.

Também em 2012, Janice Gonçalves Temoteo defendeu a tese "Lexicografia da Língua de Sinais Brasileira do Nordeste". A pesquisa de Temoteo é um estudo de documentação da LSB usada pelos surdos da Região Nordeste do Brasil, com sinais registrados dos nove Estados, a fím de dicionarizá-los no "Novo Deit-Libras: Novo Dicionário Enciclopédico Ilustrado Trilíngue da Língua de Sinais Brasileira”. O corpus da pesquisa é constituído por 4.287 sinais da LSB referentes aos nove estados do Nordeste - os sinais também são descritos e ilustrados, porém, apenas alguns exemplos são mostrados na tese.

Em 2015, Daniela Almeida Moreira apresenta a dissertação intitulada "Um estudo introdutório sobre o desenvolvimento dos repertórios léxicos da língua de sinais brasileira a partir da elaboração da definição lexicográfica". Ela apresenta um estudo sobre a lexicografia da LSB, com foco na definição lexicográfica. A pesquisa mostra a análise de quatro obras que foram consideradas como as mais representativas na lexicografia da LSB: a Linguagem das mãos de Eugênio Oates, a Linguagem de Sinais do Brasil de Harry W. Hoemann, Shirley A. Hoemann e Eugênio Oates, o Novo Deit-Libras Dicionário Enciclopédico Ilustrado Trilíngue 
da Língua de Sinais Brasileira de Fernando Cezar Capovilla, Walkiria D. Raphael e Aline C. L. Mauricio e o Dicionário da Língua Brasileira de Sinais do INES versão 2.0 de Tanya Amara Felipe de Souza e Guilherme Azambuja Lira.

\subsubsection{Impressa}

A Lexicografia impressa das LS tem a característica de representar os sinais por meio da ilustração. Este é o recurso que serviu e ainda serve para registrar as línguas de modalidade espacial e visual. Muitos dos materiais didáticos usados para o ensino de LSB em instituições como escolas, igrejas e associações, são desenhos feitos à mão por surdos. Estes materiais contribuíram para a documentação da língua. Os primeiros dicionários de língua de sinais eram, geralmente, coleções de desenhos ou fotos de sinais organizados em ordem alfabética com base em alguma língua oral, como bem mencionou Reagan (2006, p. 334).

A Lexicografia impressa limita a representação das LS - que são tridimensionais -, já que as obras em papel são bidimensionais. Sobre esta dificuldade de representação das línguas de sinais por meio de desenhos ou fotografias, Zwitserlood (2010, p. 461) adverte que nem sempre os símbolos adicionais, as sequências de imagens e as setas usadas nestas obras como informações adicionais das ilustrações - dão conta de representar os movimentos realizados pelas mãos e pelo corpo na execução do sinal, como já foi mencionado na seção sobre ilustrações em obras lexicográficas.

Sobre a limitação do suporte papel impresso, Correia (2009, p. 36) também alerta que “a publicação em papel de dicionários de gestos inibe não apenas a representação da complexidade do gesto, mas, sobretudo, a representação do movimento, que é uma das suas partes constitutivas essenciais".

Concordamos com os autores que os dicionários impressos das LS não são o melhor suporte para registrar os sinais. Vários dos problemas mencionados podem ser solucionados pela Lexicografia eletrônica. Zwitserlood (2010, p.461) apresenta quatro desvantagens dos dicionários de LS impressos. A primeira é que a representação dos sinais não é clara o bastante; a segunda diz respeito às opções de busca que são limitadas - e também o número de sinais é limitado - e, por último, os sinais não são usados no contexto.

Apresentamos, a seguir, algumas obras lexicográficas de diversas Línguas de Sinais pelo mundo. As obras selecionadas têm como suporte as línguas orais Espanhol, Francês, Inglês e Português. Primeiramente, mostramos os dicionários impressos e em seguida os eletrônicos online ou em DVD. Os dicionários impressos que apresentamos são: o 
Diccionario Básico de la Lengua de Señas Colombiana, Diccionario Bilingue Lengua de Señas Chilena - Español: Tomo II, o Manos con voz: Diccionario de Lengua de Señas Mexicana, o The American Sign Language Handshape Dictionary e o "Dicionário Enciclopédico Ilustrado Trilíngue da Língua de Sinais Brasileira: LIBRAS”. Os dicionários eletrônicos que apresentamos são: Elix: Le dictionnaire vivant en langue des signes, The Gallaudet Dictionary of American Sign Language, o The Gallaudet Children's Dictionary of American Sign Language e o "Dicionário da Língua Brasileira de Sinais: LIBRAS”.

Figura 16 - Sinal CEJA

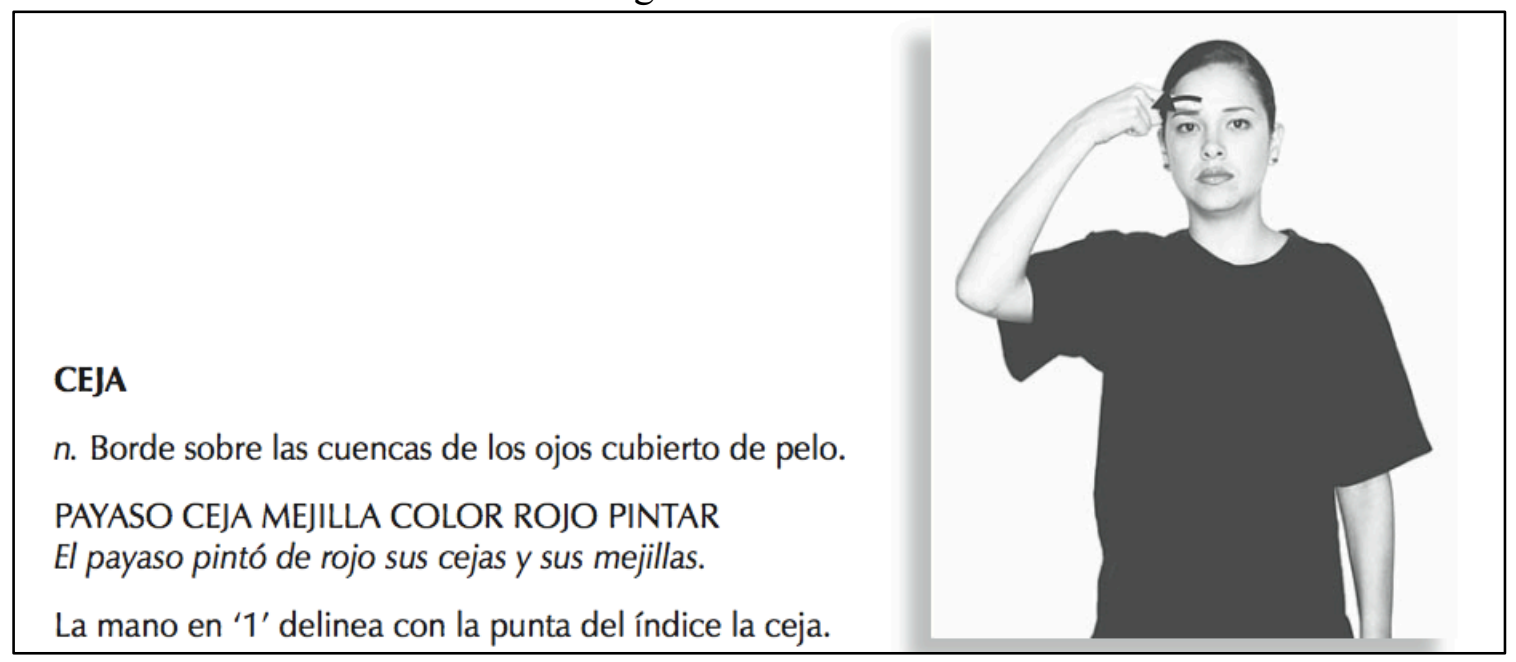

Fonte: Diccionario Básico de la Lengua de Señas Colombiana do INSOR (2006, p. 21)

A primeira obra a ser apresentada é o Diccionario Básico de la Lengua de Señas Colombiana (2006). O dicionário tem o apoio do Ministério da Educação da Colômbia e é uma realização do Instituto Nacional para Sordos (INSOR). Este é um dicionário organizado em campos temáticos e, dentro desses campos, as entradas estão dispostas em ordem alfabética. Além disso, a representação dos sinais é feita por meio de fotografia. A estrutura do verbete é composta pela microestrutura: entrada na primeira linha; na segunda, a categoria gramatical seguida da definição em língua espanhola; na terceira e quarta linhas está o exemplo de uso do sinal CEJA - na linha três está a glosa e, na linha quatro, a tradução da glosa -, na linha cinco está a descrição de como se executa o sinal e, por último, à direita, está a ilustração do sinal representada por meio de fotografia, como pode ser observada na figura 16 que representa o verbete do sinal CEJA, 'sobrancelha', da Língua de Sinais Colombiana. 
Figura 17 - Sinal JOVEN

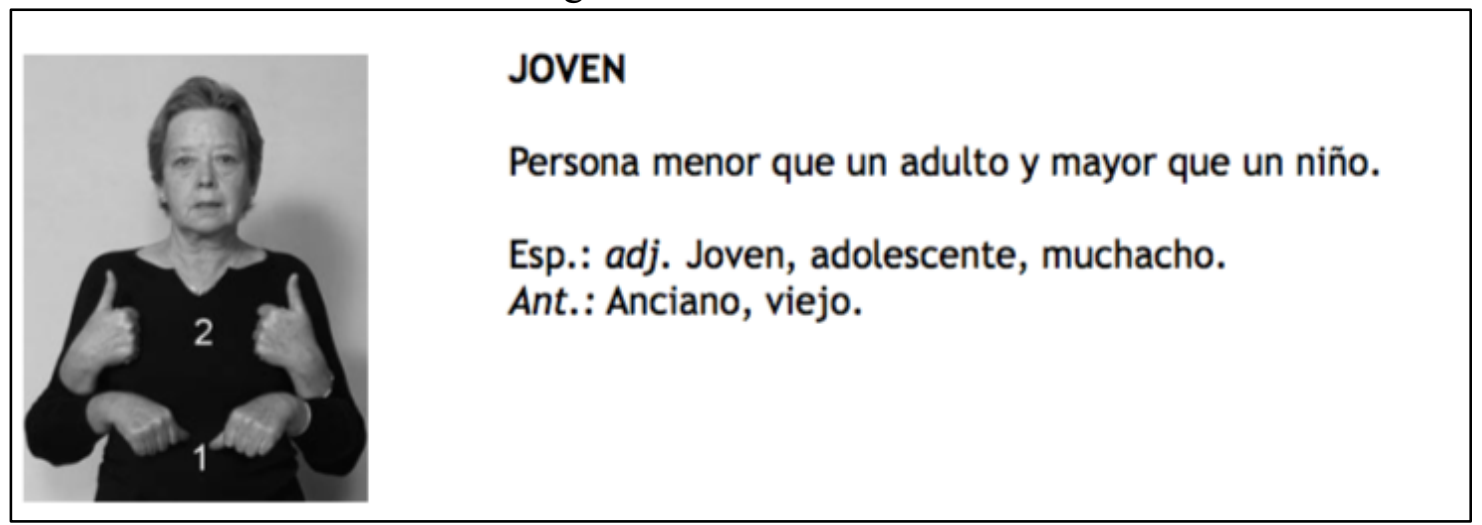

Fonte: Robertson, Quintela e Ramírez (2009, p. 56)

A segunda obra impressa que apresentamos é o Diccionario Bilingue Lengua de Señas Chilena - Español: Tomo II de Robertson, Quintela e Ramírez (2009). O dicionário está organizado em ordem alfabética e utiliza fotografias digitais para apresentar os sinais da Língua de Sinais Chilena e, sempre que necessário, utilizam um conjunto de símbolos específicos para representar os movimentos dos sinais. A estrutura do verbete é organizada da seguinte forma: do lado esquerdo, uma foto representando o sinal; do lado direito, na primeira linha, a entrada, que é uma glosa apresentada em Espanhol e com as letras maiúsculas. Na segunda linha está a definição apresentada em Língua Espanhola, mas que, de acordo com as informações contidas no dicionário, explica o significado que tem o determinado sinal da Língua de Sinais Chilena. Na terceira linha, aparecem informações relacionadas à Língua Espanhola, apresenta-se a classe gramatical por meio de abreviatura, a palavra correspondente em Espanhol e seus sinônimos; na linha quatro, estão os antônimos desta mesma língua oral, como apresentada na figura 17. 
Figura 18 - Sinal GALLO

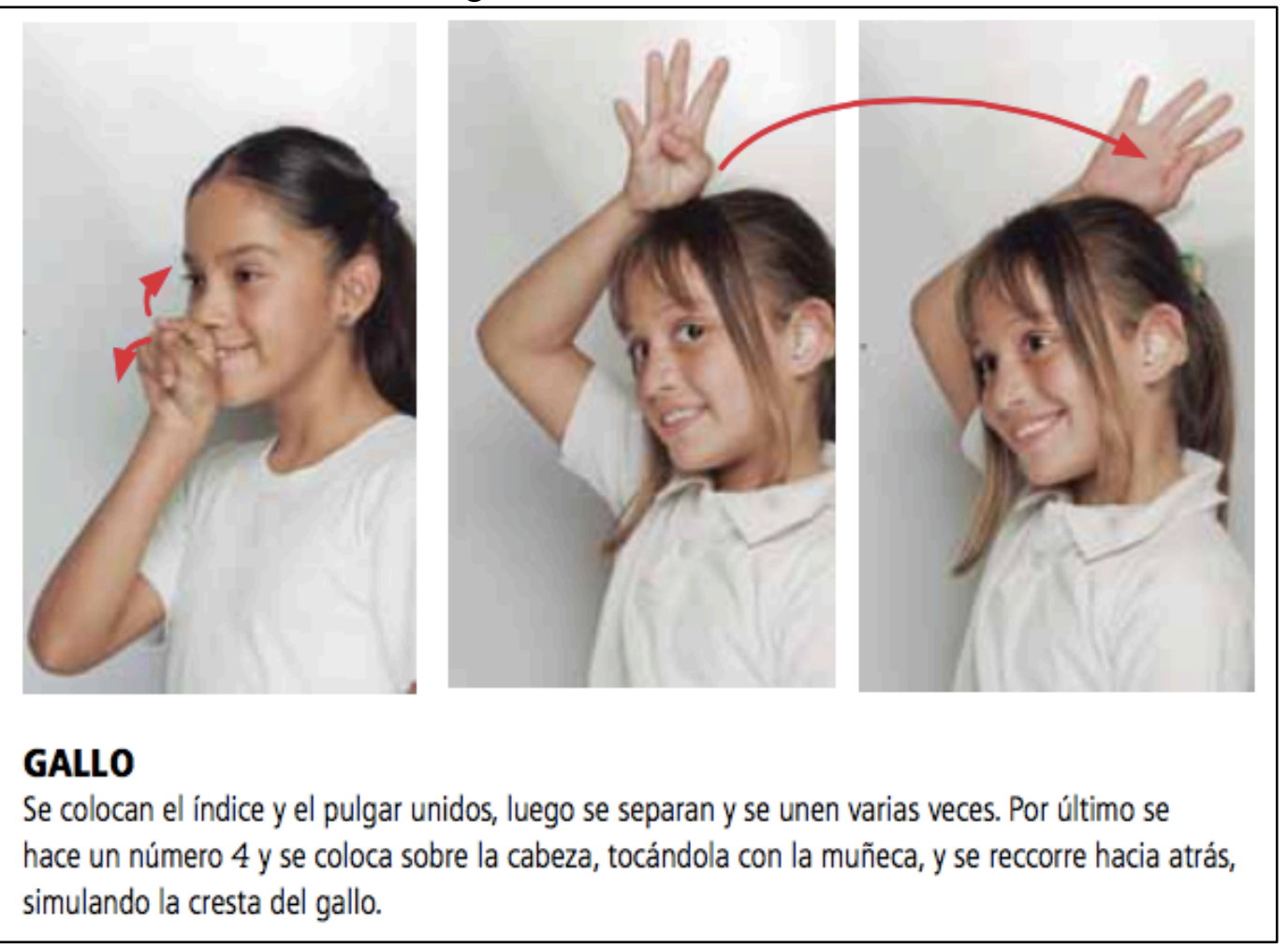

Fonte: Fleischmann e Pérez ( 2011, p. 56)

A obra lexicográfica Manos con voz: Diccionario de Lengua de Señas Mexicana de Fleischmann e Pérez (2011) é organizada por temas, os sinais são apresentados em fotografias coloridas e, quando necessário, utiliza símbolos para representação de movimentos. A estrutura do verbete é composta por uma ou várias fotos em sequência, segue a glosa em negrito e depois a explicação de como executar o sinal, conforme pode ser visto na figura 18 .

Figura 19 - Sinal BELIEVE

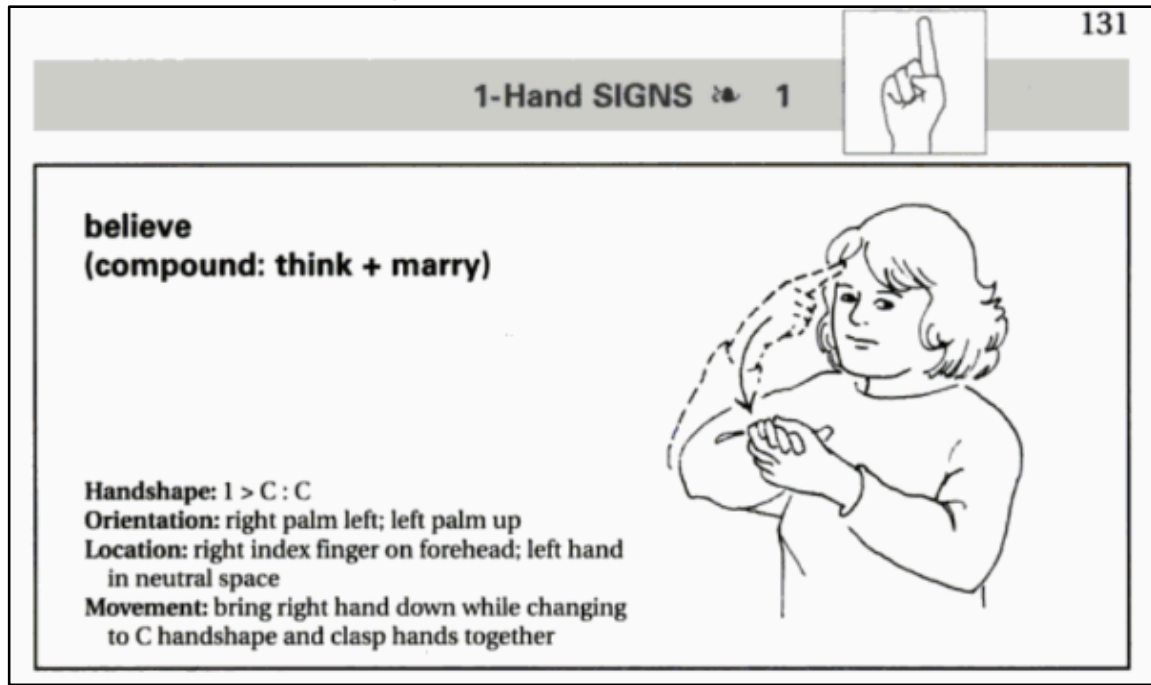

Fonte: Tennant e Brown (1998, p.131) 
O próximo material a ser apresentado é o dicionário The American Sign Language Handshape Dictionary de Tennant e Brown (1998). Esta pode ser considerada uma obra inovadora em relação ao sistema de busca dos sinais, pois a forma de organização dos verbetes é com base na configuração de mão inicial do sinal, o que permite um tipo de busca diferenciado que leva em consideração a língua de sinais. Além disso, o consulente pode encontrar o sinal sem precisar do apoio da glosa ou da Língua Inglesa, conforme explicam Tennant e Brown (1998, p. 24). Este dicionário apresenta uma proposta que se destaca da tradição de organizar os sinais apenas em ordem alfabética, com base em alguma língua oral, no caso o Inglês. As informações contidas no verbete são mais de natureza fonológica em que se apresentam a(s) configuração(ões) de mão, a(s) orientação(ões) da palma, a(s) locação(ões), o(s) movimento(s) e quando há, as expressões não manuais também são descritas. Além disso, o verbete pode conter notas que são utilizadas para sugerir como usar determinado sinal, para apresentar variações alternativas e para indicar se determinado sinal dever ser usado preferencialmente. O dicionário é organizado em três seções: a primeira é composta pelos sinais executados com apenas uma mão; a segunda, pelos sinais feitos com duas mãos; e a terceira, que é uma espécie de índice em que as glosas da ASL são apresentadas em Inglês, segue a ordem alfabética e identifica a página em que determinado sinal pode ser encontrado.

O verbete é composto pela palavra em Inglês, também denominado glosa, e quando uma só palavra em Inglês não é considerada suficiente para explicar o sentido do sinal, utilizam-se outras palavras. Em ASL, o sinal BELIEVE, 'acreditar', tem em sua composição o sinal THINK, 'pensar' junto ao sinal MARRY, 'casar', como pode ser visto no verbete da figura 19.

Figura 20 - Verbete do sinal MAR

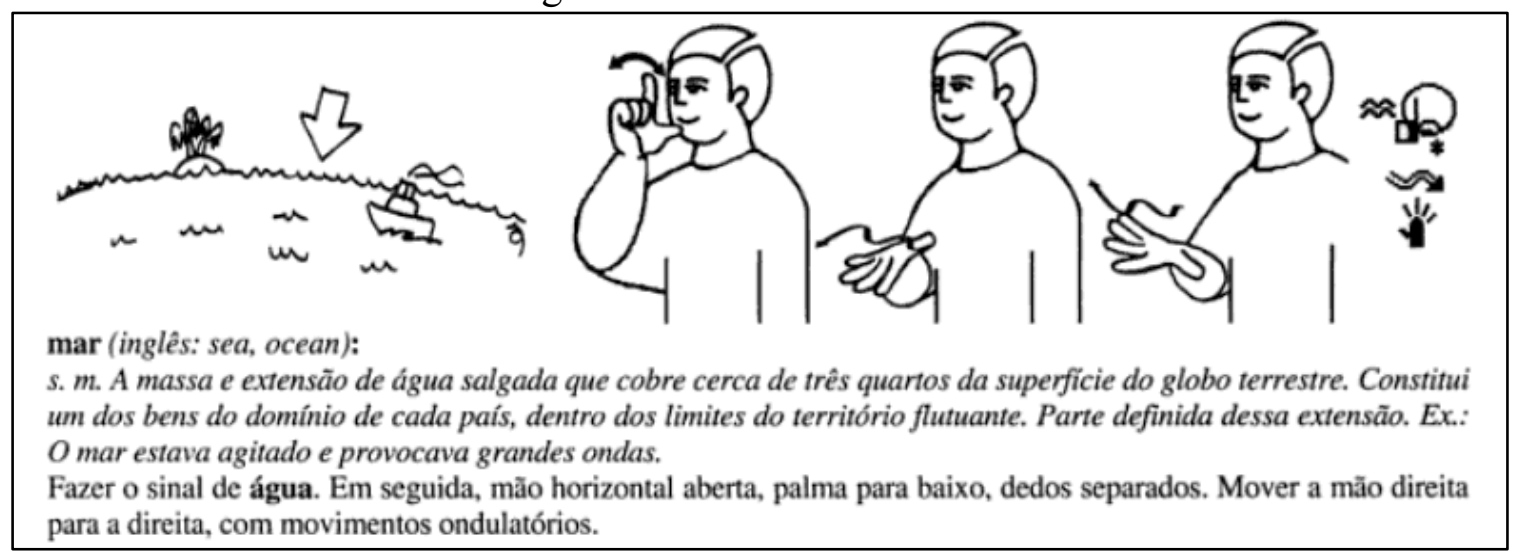

Fonte: Capovilla e Raphael (2001, p. 868) 
O último dicionário - exclusivamente impresso - que apresentamos aqui é o "Dicionário enciclopédico ilustrado trilíngue da Língua de Sinais Brasileira" de Capovilla e Raphael (2001). Este dicionário é organizado em ordem alfabética. Os verbetes apresentam a palavra-entrada em Português, Inglês e em signwriting ${ }^{35}$, a categoria, o gênero, a definição em LP, um exemplo, a explicação de como se realiza o sinal, a ilustração do objeto/conceito e a ilustração do sinal, conforme podemos conferir na figura 20.

Com os avanços, notamos também o uso de novas tecnologias para o desenvolvimento da Lexicografia das LS. As primeiras obras têm como forma de representação o desenho dos sinais, que são identificados por palavras da LO. Esta prática é recorrente até os dias de hoje e ainda tem sido a escolha de muitos para o registro dos sinais, sendo o tipo de obra lexicográfica mais comum. Em decorrência dos avanços tecnológicos, a fotografia também passou a fazer parte das obras lexicográficas e, posteriormente, a tecnologia dos vídeos permitiu um registro mais fiel dos elementos constitutivos das LS. Com base no desenvolvimento dessas tecnologias, podemos classificar as obras em impressas e eletrônicas.

\subsubsection{Eletrônica}

Indubitavelmente, há inúmeras vantagens do suporte eletrônico para a lexicografia das LS. Os sinais podem ser registrados em vídeos e dar maior clareza de como o sinal deve ser executado. Todavia, filmar sinais isolados pode ocasionar expressões não manuais inadequadas que, fora do contexto da sinalização, podem se tornar artificiais e inapropriadas.

As obras lexicográficas em LS têm evoluído com as novas tecnologias disponíveis. Mesmo com o desenvolvimento tecnológico, algumas obras lexicográficas ainda continuam com as ilustrações dos sinais e a busca apenas pelo sistema alfabético da língua oral de maior contato da comunidade Surda. Apresentamos a seguir os quatro dicionários eletrônicos mencionados anteriormente.

\footnotetext{
${ }^{35}$ Sistema de Escrita criado por Valerie Sutton (1974).
} 
Figura 21 - Verbete do sinal MOT 'palavra'

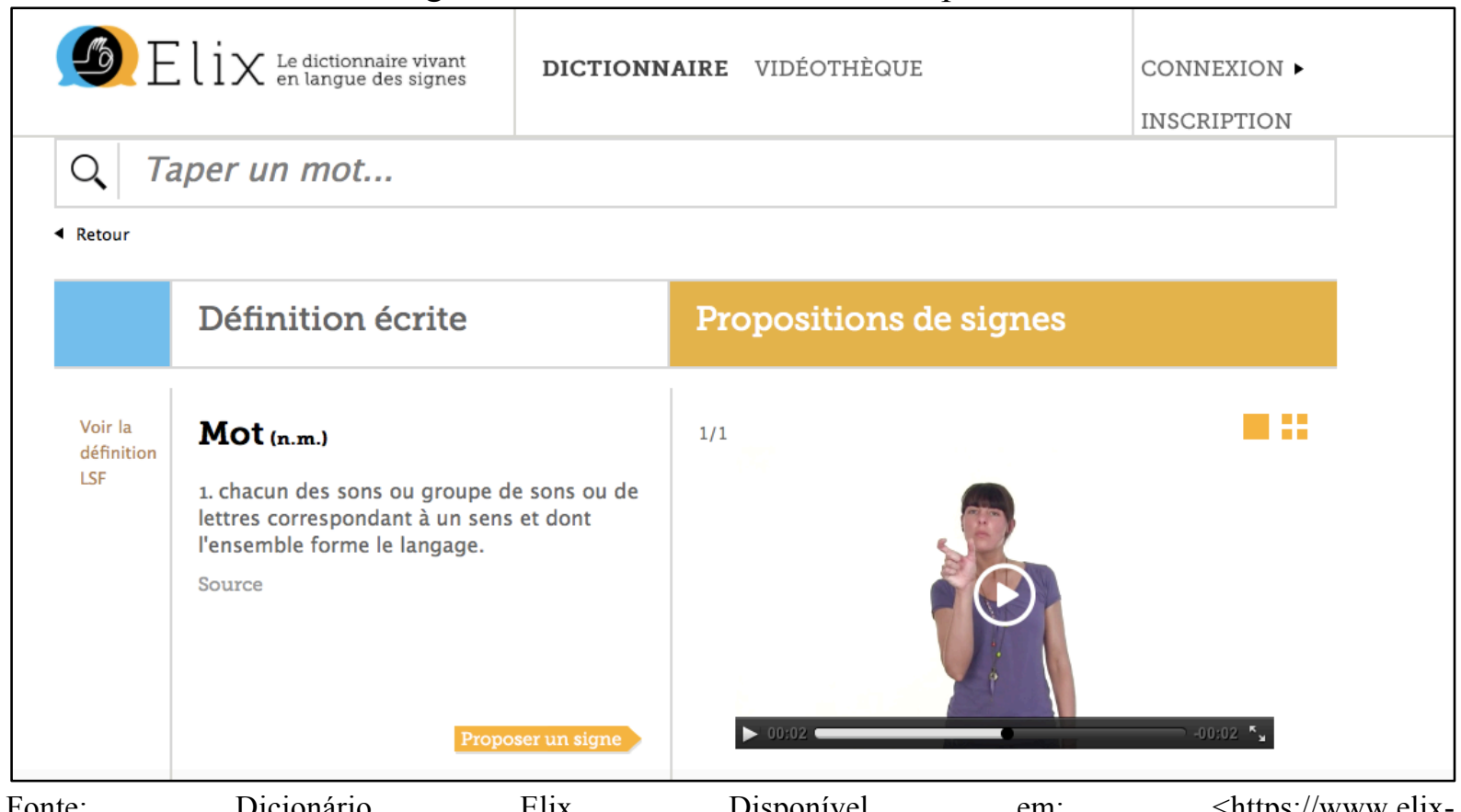

1sf.fr/spip.php?page=signes\&id_article=190514\&type_vue=unitaire\&lang=fr $>$. Acesso em: $14 \mathrm{dez} 2015$.

O primeiro dicionário eletrônico que apresentamos é o Elix: Le dictionnaire vivant en langue des signes da Língua de Sinais Francesa. A obra está disponível na internet em https://www.elix-lsf.fr/?lang=fr e o sistema de busca do verbete dá-se pela digitação da palavra em Francês. A estrutura do verbete é composta pela definição em LSF filmada, a definição em Francês escrito que é composta de informação sobre a categoria, o gênero da palavra e o vídeo do sinal. Ademais, há um espaço para propor novos sinais da LSF.

Figura 22 - Verbete impresso

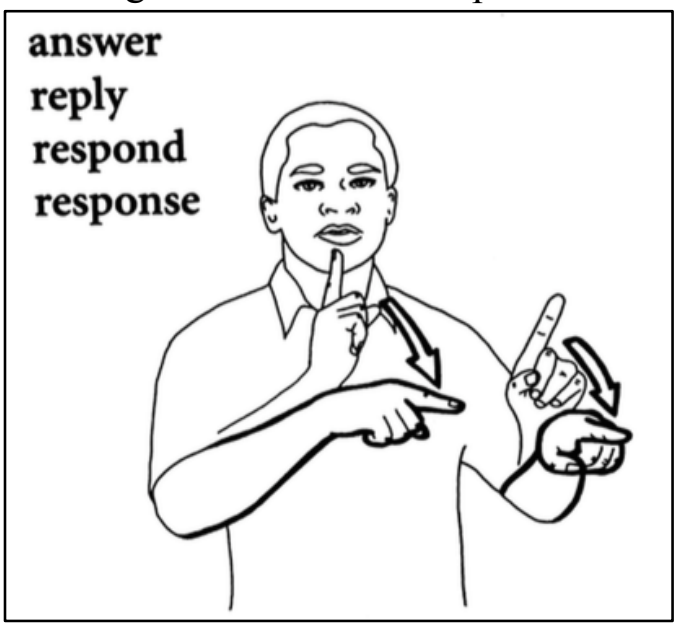

Fonte: Valli (2005, p. 18) 
Figura 23 - Verbete ANSWER 'responder'

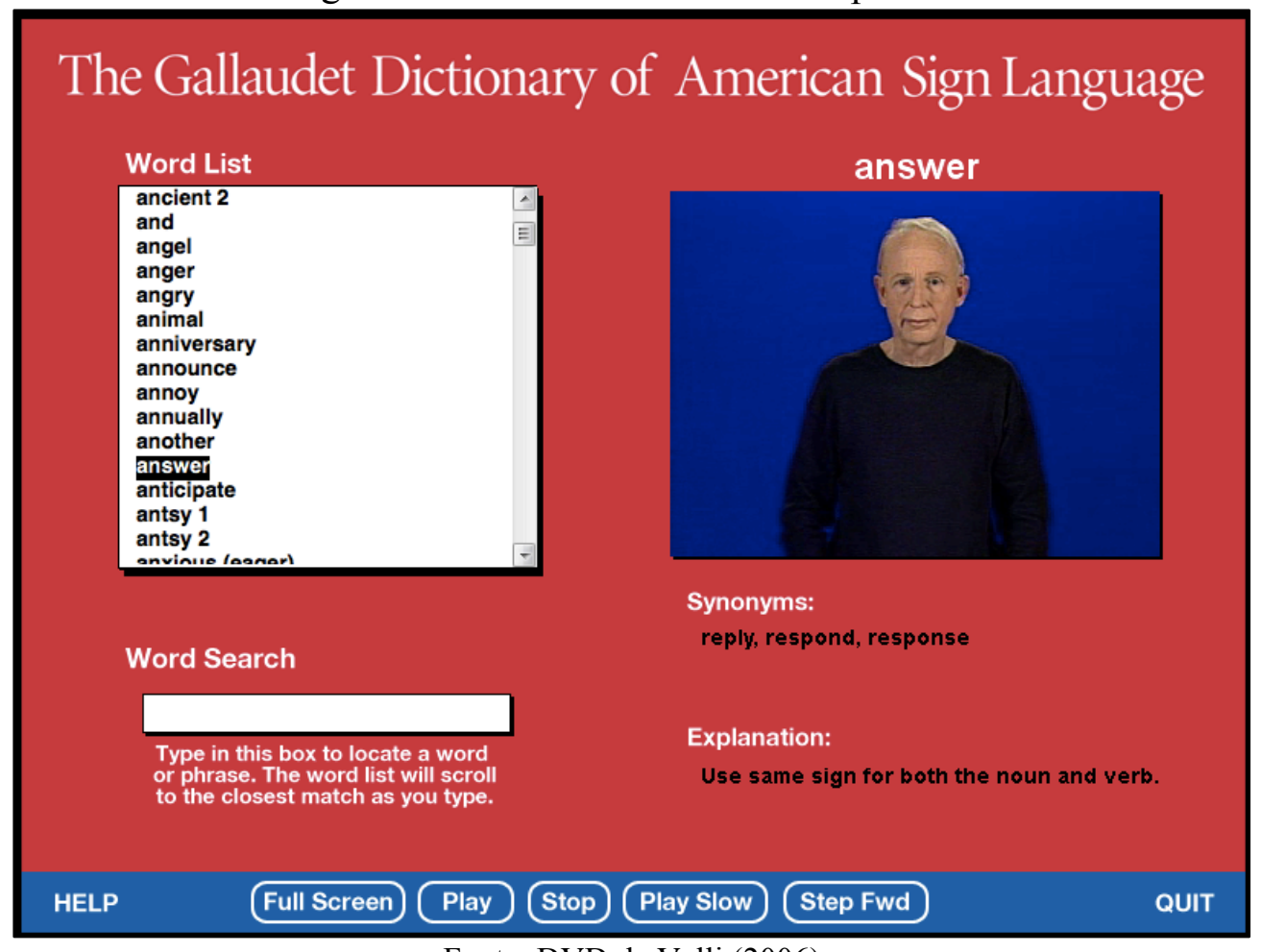

Fonte: DVD de Valli (2006)

O segundo dicionário eletrônico é o The Gallaudet Dictionary of American Sign Language de Valli (2005), é impresso e contém um DVD com a execução dos sinais. Esta obra não é exclusivamente eletrônica, assim como o dicionário infantil que apresentamos a seguir.

A figura 22 mostra a estrutura do verbete da parte impressa do dicionário. A parte da obra que se apresenta em suporte de papel tem a seguinte microestrutura: a ilustração do sinal em desenho preto e branco e o(s) correspondente(s) em Inglês. É valido dizer que o mecanismo de busca das palavras está em ordem alfabética nas partes impressa e eletrônica.

$\mathrm{Na}$ figura 23, apresentamos a parte eletrônica deste dicionário, que é um DVD. O verbete no DVD apresenta a seguinte microestrutura: entrada em Inglês, um vídeo com a execução do sinal, abaixo do vídeo os sinônimos da entrada em Inglês e a explicação de algum sinal, quando necessário. O suporte em DVD apresenta algumas funcionalidades: do lado esquerdo do verbete, há uma lista de palavras - denominada de wordlist - que pode ser vista completamente clicando o cursor para baixo; logo embaixo está o recurso de busca em que se digita a palavra ou frase desejada no espaço chamado de Word search. Ademais, podem ser encontradas as ferramentas: help, full screen, play, stop, play slow, step fwd e quiet. O recurso help explica cada uma das funcionalidades da parte eletrônica. O fullscreen permite aumentar o tamanho da tela de execução do sinal. Já o play tem a função de iniciar o 
vídeo com o sinal, o stop serve para interromper a sinalização. O play slow mostra o vídeo em uma execução mais lenta e o stepfwd é o recurso de avançar para o próximo sinal. E, finalmente, o quit é o mecanismo de sair do dicionário.

Figura 24 - Ilustração do verbete do sinal ABOUT 'sobre'

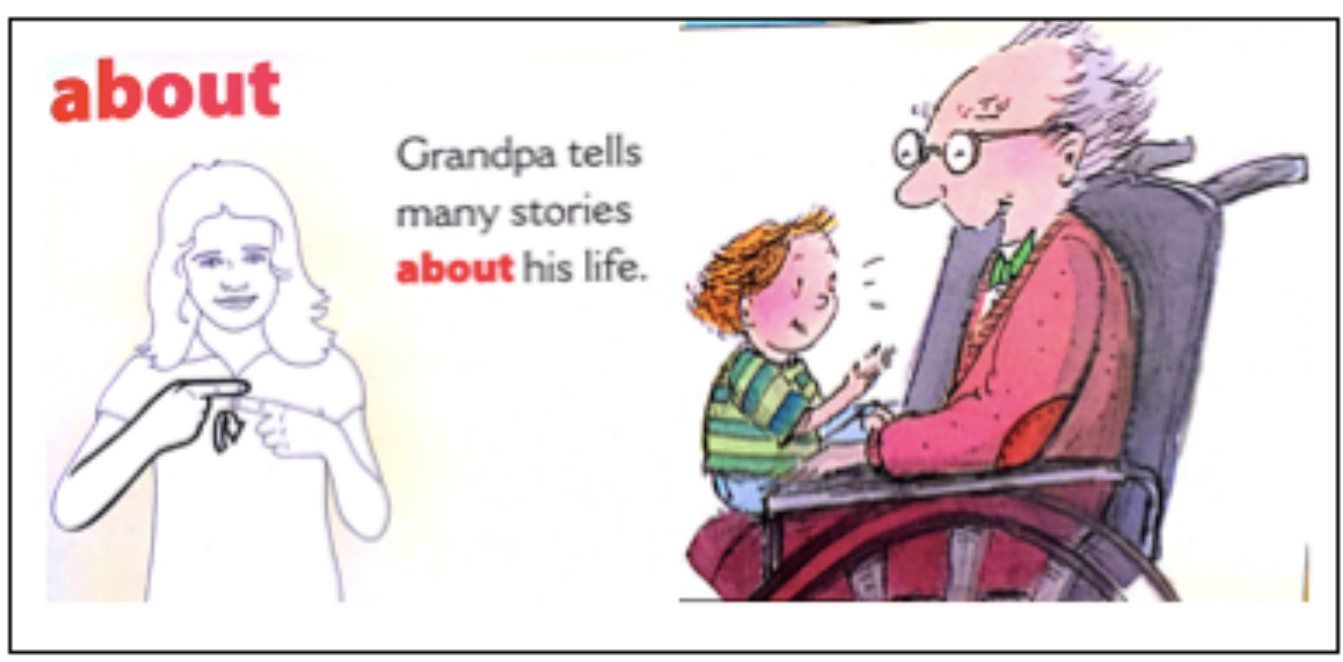

Fonte: Gordon et al. (2014, p. 1)

O terceiro dicionário que apresentamos é o The Gallaudet Children's Dictionary of American Sign Language de Gordon et al. Esta é uma obra infantil que, assim como o dicionário anterior, possui uma parte impressa e uma eletrônica, ambas organizadas em ordem alfabética. A microestrutura do verbete impresso é constituída pela entrada em Inglês padronizada na cor vermelha - quando há sinônimos são listados abaixo da entrada na cor preta. $\mathrm{O}$ verbete tem uma frase mostrando o uso da entrada que se relaciona diretamente com a ilustração em cores contida em cada microestrutura, e a representação do sinal é um desenho em preto e branco, como pode ser conferido na figura 24 .

Tal qual a publicação impressa, a parte eletrônica do dicionário apresenta a entrada na cor vermelha. Além disso, o sinal é executado por uma criança surda, e se repete automaticamente. Há um ícone verde, no formato de tartaruga, que tem a função de apresentar a execução do sinal de forma mais lenta. Estes mecanismos de velocidade e de repetição também funcionam quando há um vídeo com a frase em ASL, que demonstre o uso do sinal a sentença em ASL é apresentada por um ator adulto.

A ilustração e a frase de como usar o sinal são as mesmas na parte impressa e na eletrônica do dicionário. No caso da frase, na parte impressa, a língua usada é o Inglês escrito e na parte eletrônica é em ASL sinalizada. Além disso, todos os sinais que constam do 
dicionário impresso estão na parte eletrônica em vídeo. Apenas 150 frases com exemplos de uso do sinal estão no DVD.

Figura 25 - Verbete do sinal PALAVRA

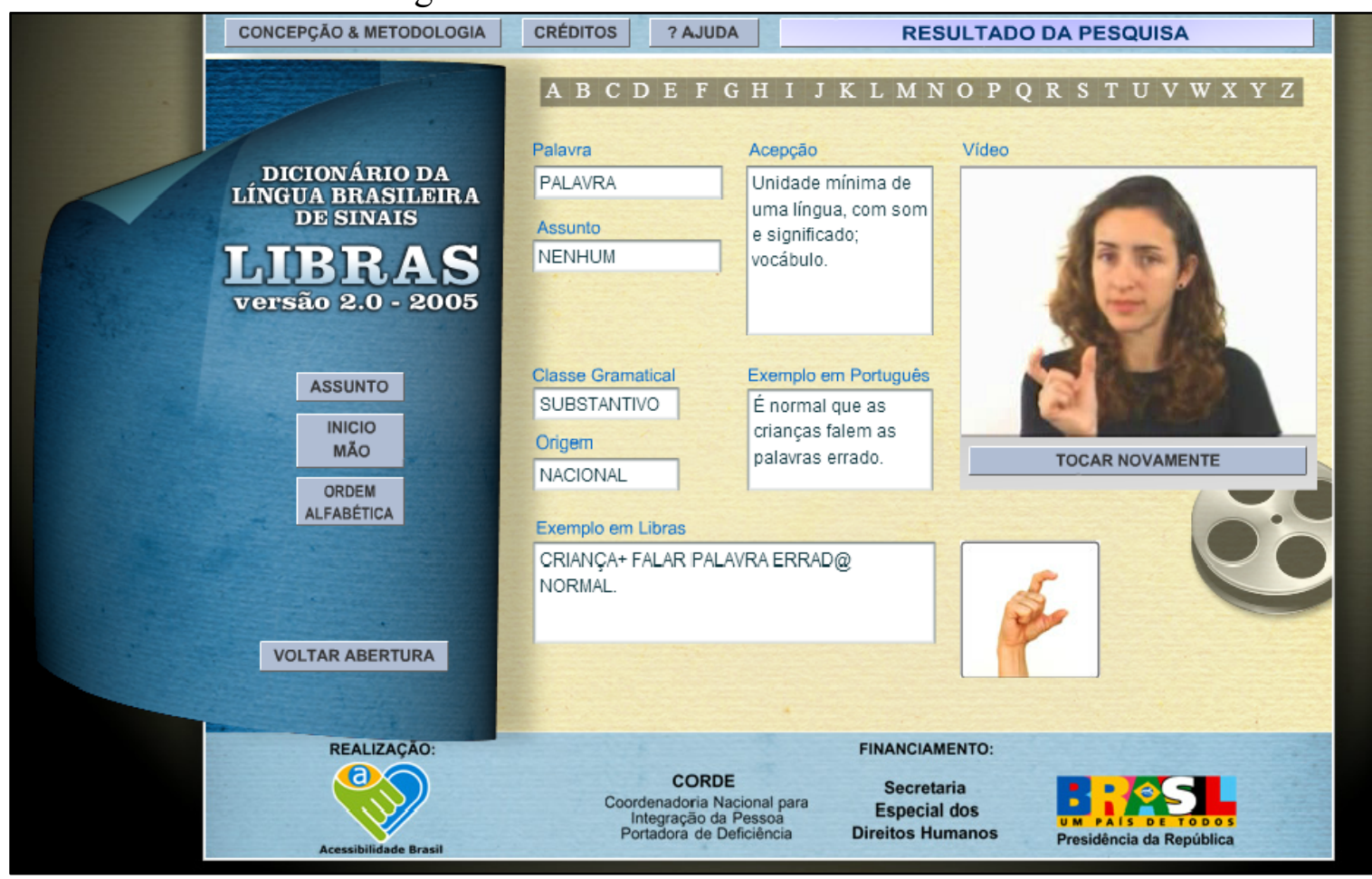

Fonte: Felipe e Lira (2005)

Por fim, o Dicionário da Língua Brasileira de Sinais: LIBRAS versão 2.0 (2005) de Felipe e Lira é um marco na lexicografia brasileira pela inovação do suporte eletrônico e por permitir a busca por um dos parâmetros da LSB, a CM inicial do sinal. O dicionário apresenta outras forma de busca, como pesquisar por assunto, que está organizado em 21 campos temáticos, e a busca pela LP usando o alfabeto ou digitando a palavra.

As informações encontradas nos verbetes são: a entrada, o assunto (campo temático em que a palavra está inserida), a classe gramatical, origem, acepção, exemplo em LP, exemplo em LSB por meio de glosa, um vídeo com a execução do sinal e a CM inicial do sinal em destaque. Este dicionário possui também um recurso para repetição do sinal. Quanto à parte denominada origem, é uma função que não está clara no glossário. E o exemplo em LSB por glosa também é problemático já que a transcrição se utiliza da Língua Portuguesa e não se pode ter certeza de quais sinais seriam usados em LSB. 
Figura 26 - Aplicativos e recurso de tecnologia assistiva

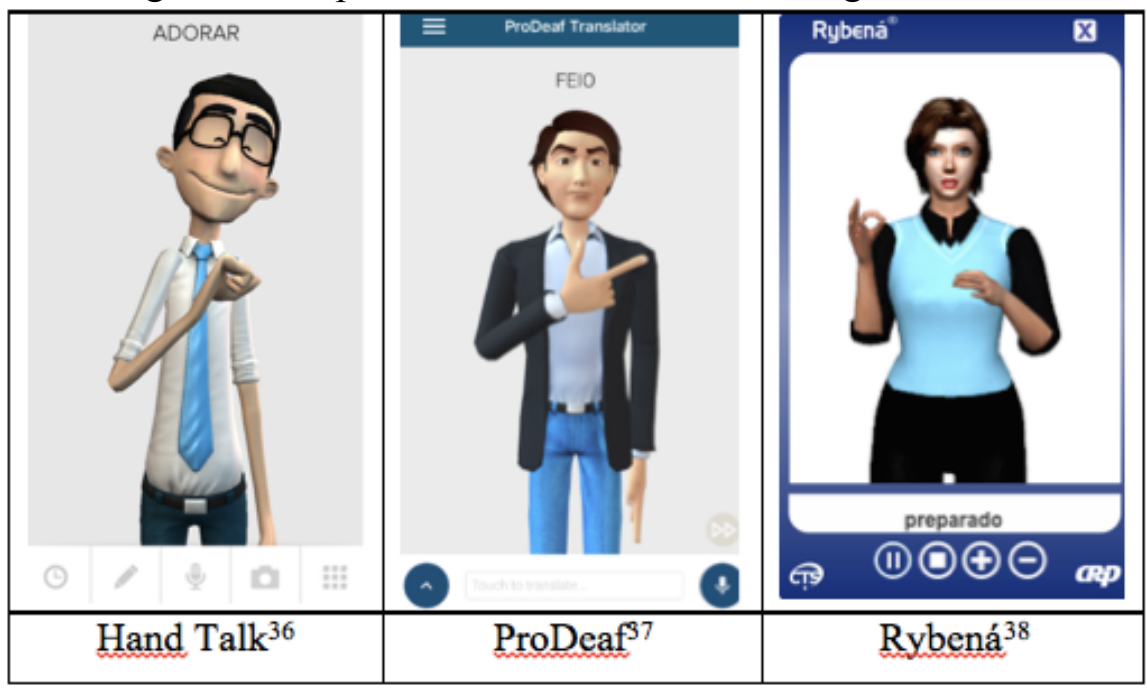

Fonte: Elaborada pela autora

Ainda sobre as obras eletrônicas para LSB, gostaríamos de mencionar os aplicativos Hand Talk e o ProDeaf, bem como o Rybená, que é um recurso de tecnologia assistiva. Esses três recursos tecnológicos não são dicionários da LSB, apesar de que o ProDeaf também é considerado como dicionário por seus criadores, possuem a função de tradutores do português para LSB, todavia, às vezes podem ser usados para se chegar a alguns sinais. Obviamente essas ferramentas ainda não conseguem fazer uma tradução sem defeitos. Para isso, é preciso um longo trabalho de descrição da sintaxe da LSB para estabelecimento de referências, de relações sintáticas pelas expressões não manuais, os usos lexicais dos sinais, bem como o aprofundamento dos estudos para a tradução automática de português para LSB. É válido mencionar que os aplicativos ProDeaf e HandTalk são softwares livres e qualquer pessoa que dispõe de um Smartphone ou tablet pode ter acesso. Essas obras têm aperfeiçoado as expressões não manuais dos sinais, o que sem dúvida é um elemento essencial na produção da língua.

Para a criação do nosso glossário, não identificamos, até o momento, nenhuma obra lexicográfica ou terminológica direcionada ao nosso público-alvo da mesma faixa etária; tampouco com objetivos que se assemelhem à nossa proposta. Desta feita, consultamos as obras mencionadas, tendo como suporte teórico as áreas da Terminologia e da Lexicografia, bem como apresentamos e descrevemos as funcionalidades identificadas nas obras lexicográficas das LS no intuito de chegarmos a um modelo que atenda às especificidades e necessidades educacionais dos surdos do Ensino Fundamental II.

Consideramos o glossário da BSL a obra mais completa em termos de informações em LS e na busca de estratégias que esclareçam os termos científicos. Além disso, o fato de 
contarem com uma equipe de surdos cientistas é uma característica necessária em todo processo terminográfico, mas que nem sempre é possível ter essa situação ideal.

Como pudemos observar ao longo deste capítulo, poucas são as obras que contêm a definição em LS, ou mesmo que deixem explícita a preocupação de apresentar as definições da LO na perspectiva de uma segunda língua. Apesar de nossa proposta não apresentar a definição em LSB, apresentamos reflexões sobre a temática na próxima seção.

\subsection{Definição no âmbito da lexicografia para surdos}

A elaboração de definições em LS é outro desafio que essas línguas enfrentam e, por isso, é difícil de ser encontrada em dicionários de LS. Isso ocorre mesmo quando o dicionário é eletrônico, já que para os impressos é inviável. Em geral, nesses dicionários, encontramos apenas os equivalentes em LS, sem definição, e quando há, estão disponíveis apenas na língua oral, sem a preocupação de adequar à linguagem para uma segunda língua.

Vários são os questionamentos que surgem ao se pensar na definição em LS. A definição será apenas traduzida? Quais as regras para a tradução de definições? A datilologia pura será abolida das definições, ou ao menos evitada? Como manter a sistematicidade das definições em LS? Como podem ser organizadas as definições em LS? O modelo canônico e as orientações lexicográficas para os verbetes são adequados para obras que registrem uma língua de sinais? Certamente ainda não temos condições de responder a essas perguntas, apenas são postas aqui para reflexão.

A maioria das obras lexicográficas da LSB existente privilegia o consulente ouvinte, não só por a busca ser praticamente apenas pela Língua Portuguesa, como também pela linguagem encontrada nas definições. Isso faz com que os dicionários sejam mais úteis aos ouvintes que estão aprendendo LSB do que propriamente ao surdo que deseja compreender o conceito de algo.

Uma exceção é o "Glossário Libras da Universidade Federal de Santa Catarina”. Este trabalho surgiu no Ambiente Virtual de Aprendizagem do curso Letras Libras à distância em que a maioria dos estudantes era surda. Este glossário saiu do ambiente restrito do curso virtual e pode ser acessado livremente no site, como apresentamos anteriormente. O avanço é que os glossários apresentam a definição dos termos em LSB e foi pensado para as necessidades dos consulentes surdos. A língua de destaque é a Língua de Sinais Brasileira, todavia, as definições não seguem nenhum padrão - são tentativas de explicar os conceitos sem critérios lexicográficos definidos previamente. 
Bienvenu (2003) em sua tese de doutorado criou uma proposta de dicionário monolíngue para ASL. Por se tratar de um modelo de uso da língua comum e não de uma área de especialidade, como é o nosso trabalho, ela parte da intuição do sinalizante nativo da ASL e valida as acepções e os usos que determinado sinal tem. As regras estabelecidas na pesquisa de Bienvenu (2008, p. 55) para criar as definições foram: simplicidade, evitar circularidade e negação, brevidade e evitar o uso do sinal que está sendo definido. No entanto, até o momento, não identificamos se há técnicas descritas em artigos acadêmicos sobre a definição em língua de sinais.

Sobre a definição lexicográfica, Ilari (2008, p. 55-56) lista os aspectos que não devem estar presentes: ser uma mera enumeração de exemplos, circularidade, obscuridade (com termos difíceis), demasiado ampla, demasiado estreita, figurada e negativa.

Apesar do nosso glossário não conter a definição dos termos em LS, entendemos que a ausência de sinais-termo na LSB é um fator complicador no desenvolvimento de definições nesta língua, pois para criar a definição de um termo em LSB, dependemos de outros termos que, muitas vezes, não existem nesta língua. E quando não houver? Usaremos datilologia?

O recurso da datilologia na LSB é uma ferramenta útil e produtiva, contudo, nas definições, não contribui para a elucidação dos termos. É importante ter em mente que o verbete deve esclarecer um lema. Por causa da ausência de termos em LS, várias palavras acabariam por ter de ser esclarecidas em um único verbete para que a entrada fizesse sentido.

Abordamos a problemática que envolve a definição em LS por considerarmos a discussão relevante para o nosso estudo. Isso porque, em decorrência das dificuldades de se elaborar definições em LS, criamos um método para reformular as definições e adaptar a linguagem do nosso glossário para um Português mais acessível aos surdos, que demonstramos no capítulo 3, no qual descrevemos os procedimentos metodológicos.

\subsection{Síntese do capítulo}

Neste capítulo, discutimos temas relevantes para a criação da proposta de glossário. Primeiramente, apresentamos a área Terminologia e sua relação com a formação de novas unidades terminológicas. Em seguida, discutimos como a terminologia e a política linguística motivam e influenciam nossa proposta. Apresentamos a importância da Terminologia nas LS e mostramos algumas obras de áreas de especialidade no Brasil e no mundo com registros terminológicos de LS. Seguimos com a apresentação de conceitos da Lexicografia, que norteiam as características do glossário. Além disso, discutimos a ilustração em dicionários de 
LOs e de LS, bem como discorremos sobre a Lexicografia das LS em seus registros impressos e eletrônicos, descrevemos as funcionalidades e características encontradas nas obras lexicográficas das LS, com vista ao desenvolvimento de nossa proposta. Por fim, refletimos sobre a definição lexicográfica e terminológica tendo em vista o público-alvo, surdos que têm o Português como segunda língua. No próximo capítulo, apresentamos os procedimentos metodológicos para a construção do glossário. 


\section{CAPÍTULO 3: PROCEDIMENTOS METODOLÓGICOS}

\subsection{O público-alvo e as suas singularidades}

Para a criação de uma obra terminográfica, faz-se necessário tomar várias decisões que nortearão a confecção do trabalho. Uma dessas decisões é definir para quem a obra se destina. Neste caso, o glossário semibilíngue foi idealizado para estudantes surdos da educação básica que cursam os anos finais do Ensino Fundamental, que vai do $6^{\circ}$ ao $9^{\circ}$ ano, com a duração de quatro anos, sinalizantes da Língua de Sinais Brasileira (LSB) e usuários da modalidade escrita da Língua Portuguesa (LP) como segunda língua (L2), com idade entre 11 e 14 anos. Porém, ao decidir por esse público, aparentemente homogêneo, várias questões e desafios são postos em discussão por ser um grupo linguístico bem diversificado.

Quando observamos os surdos em diferentes espaços sociais, percebemos que se trata de uma comunidade heterogênea em sua forma de comunicação. Existem surdos com domínio $^{36}$ de Língua de Sinais Brasileira e de Língua Portuguesa muito diferentes, que vai do nível mais elementar à proficiência plena, numa situação de bilinguismo individual. Além disso, é comum o atraso na aquisição da linguagem dos surdos, isto significa dizer que o contato com a LSB pode ter ocorrido tardiamente, fora dos períodos de aquisição da linguagem. Posto isso, fica clara a singularidade linguística desse público-alvo em relação aos ouvintes, porque estes têm uma língua plena, dominam a Língua Portuguesa. É válido esclarecer que não se trata de o sujeito ouvinte saber mais ou menos o Português padrão. Trata-se de que o ouvinte tem o domínio de, pelo menos, uma língua, o Português.

Infelizmente, não é essa a realidade dos surdos. Algumas tentativas de oralizá-los, de incentivá-los apenas ao aprendizado da Língua Portuguesa, o não incentivo ao contato com a língua de sinais, ou o aprendizado tardio desta língua, são entraves para que o surdo adquira uma língua plena.

Essa situação nos leva a pensar em pesquisas que contemplem as necessidades de um público heterogêneo, porém, com a característica comum de aquisição de língua visual e espacial. Essa reflexão tem sido um dos pontos norteadores para atender à heterogeneidade linguística dos surdos.

\footnotetext{
36 Compreendemos domínio de uma língua como a autonomia do indivíduo em se expressar em determinada língua desde um nível bem elementar, como cumprimentar alguém, até o nível mais elevado em que o uso da língua se dá nas mais variadas situações da vida.
} 
Delimitado o público-alvo e levando-se em consideração as suas idiossincrasias, apresentamos uma lista dos procedimentos metodológicos propostos para a criação da obra terminográfica semibilíngue para surdos, que é objeto de nosso estudo.

\subsection{Procedimentos metodológicos em 15 passos}

Para elaboração do glossário semibilíngue, listamos, a seguir, os procedimentos metodológicos adotados:

1. recolha de termos da área do Meio Ambiente para composição de fichas lexicográficas;

2. criação de fichas lexicográficas em LP dos termos selecionados;

3. busca de definições dos termos em obras lexicográficas de referência;

4. reformulação das definições extraídas de materiais lexicográficos e terminográficos existentes e adaptação da linguagem ao público-alvo;

5. organização dos termos em campos temáticos e preparação de materiais visuais para a apreensão de conceitos durante as sessões de criação e validação;

6. pesquisa e identificação de termos do Meio Ambiente na LSB

7. promoção das sessões de criação de sinais-termo;

8. promoção das sessões de validação de sinais-termo;

9. filmagem dos sinais-termo

10. armazenamento dos sinais-termo;

11. criação das ilustrações dos termos do Meio Ambiente e revisão por especialistas;

12. desenho do modelo do glossário para criação do suporte em mídias digitais;

13. descrição da composição fonológica dos sinais-termo para busca pelo sinal no suporte digital;

14. registro dos dados no suporte digital e;

15. Divulgação do glossário.

Seguem descritos cada um desses procedimentos. 


\subsubsection{A recolha de termos da área do Meio Ambiente para composição de fichas lexicográficas}

O jornal Folha de São Paulo, além de ser de grande circulação no Brasil, tem a vantagem de ser encontrado nas versões impressa e eletrônica, disponível no endereço http://www.folha.uol.com.br/. Porém o acesso às informações é limitado, caso o leitor não seja assinante do diário. Para a pesquisa dos termos da área do Meio Ambiente, utilizamos o periódico a partir do site da Folha por possuir uma ferramenta na página com as matérias organizadas por temas. Esta disposição do jornal serviu como ferramenta para encontrar os textos, contextos e termos do Meio Ambiente da Língua Portuguesa que comporão o corpus da pesquisa para criar a obra terminográfica semibilíngue, como mostra a figura 27.

Figura 27 - Site do Jornal Folha de S. Paulo

\begin{tabular}{|c|c|c|c|c|}
\hline \multirow{3}{*}{$\star \star \star$} & a Logout & \multirow{2}{*}{$\begin{array}{l}\text { COTIDIANO } \\
\text { Cotidiano } \\
\text { Educação }\end{array}$} & \multirow{2}{*}{$\begin{array}{l}\text { CULTURA } \\
\text { llustrada } \\
\text { Cartuns }\end{array}$} & \multirow{2}{*}{$\begin{array}{l}\text { + SEÇÖES } \\
\text { Acervo Folha } \\
\text { Em Cima da Hora }\end{array}$} \\
\hline & $\checkmark$ Assine a Folha & & & \\
\hline & 2 Atendimento & $\begin{array}{l}\text { Loterias } \\
\text { Pelo Brasil }\end{array}$ & $\begin{array}{l}\text { Comida } \\
\text { Grade de TV }\end{array}$ & $\begin{array}{l}\text { Erramos } \\
\text { Especiais }\end{array}$ \\
\hline \multirow{2}{*}{$\begin{array}{l}\text { FOLHA DE S.PAULO } \\
\text { Sobre a Folha }\end{array}$} & 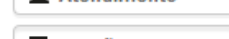 & Ranking Universitário & Guia & Folha Transparência \\
\hline & 围 Versão Impressa & Revista sãopaulo & Ilustríssima & Folha Întegra \\
\hline \multicolumn{2}{|l|}{ Expediente } & Ribeirão Preto & Quadrinhos & Folhinha \\
\hline Fale com a Folha & POLITICA & Rio de Janeiro & Serafina & Fotografia \\
\hline Folha en Español & Poder & Trânsito & & Horóscopo \\
\hline Folha in English & Poder\&Política & & TEC & Infográficos \\
\hline E-mail Folha & Folhaleaks & ESPORTE & Tec & Turismo \\
\hline \multicolumn{2}{|l|}{ Empreendedor Social } & Esporte & & Folha 10 \\
\hline \multicolumn{2}{|l|}{ Fale Conosco } & Folha na Copa & F5 & Minha História \\
\hline \multirow{2}{*}{$\begin{array}{l}\text { Ombudsman } \\
\text { Atendimento ao Assinante }\end{array}$} & Mundo & Paulista 2013 & F5 & \\
\hline & BBC Brasil & Rio 2016 & Bichos & TV FOLHA \\
\hline ClubeFolha & Deutsche Welle & Tênis & Celebridades & TV \\
\hline $\begin{array}{l}\text { PubliFolha } \\
\text { Banco de Dados }\end{array}$ & Financial Times & Turfe & Colunistas & \\
\hline \multirow{2}{*}{$\begin{array}{l}\text { Banco de Dados } \\
\text { Datafolha }\end{array}$} & The Guardian & Velocidade & Estranho! & CLASSIFICADOS \\
\hline & The New York Times & & Eu Amo & Empregos \\
\hline & CIENCIA & Factoides & Imóveis \\
\hline \multicolumn{2}{|l|}{ Treinamento } & Ciência & \#fofices & Negócios e Carreiras \\
\hline \multirow{2}{*}{$\begin{array}{l}\text { Trabalhe na Folha } \\
\text { Publicidade }\end{array}$} & Mercado & Ambiente & Fotos & Veículos \\
\hline & Folhainvest & & Horóscopo & \\
\hline \multirow{7}{*}{$\begin{array}{l}\text { Feeds do site } \\
\text { Regras de acesso ao site }\end{array}$} & Indicadores & SAUDE & Humanos & PAINEL DO LEITOR \\
\hline & & Equilibrio e Saúde & Televisão & Painel do Leitor \\
\hline & OPINIÄO & & Vídeos & Envie sua Notícia \\
\hline & Editoriais & & & Paute a Folha \\
\hline & Blogs & & & Semana do Leitor \\
\hline & Colunas & & & \\
\hline & Tendências/Debates & & & \\
\hline
\end{tabular}

Fonte: Folha de São Paulo. Disponível em: <http://www.folha.uol.com.br>. Acesso em: 19 jan. 2014.

Do conteúdo do jornal Folha de São Paulo, selecionamos a categoria denominada "Ciência" que apresenta a subcategoria "Ambiente" ${ }^{37}$, seção de onde os dados foram coletados. As matérias da subcategoria "Ambiente" foram colhidas, levando-se em

\footnotetext{
${ }^{37}$ Narvaes (2012, p. 221) apresenta o verbete do termo Meio Ambiente da seguinte forma: "A expressão "meio ambiente" não é utilizada por muitos estudiosos, pois ela é composta por duas palavras que são sinônimas (...). A forma correta é utilizar apenas ambiente ou meio. Mesmo incorreta (...), essa terminologia é muito difundida e é considerada clássica, sendo utilizada por muitos".
} 
consideração a data de publicação. Os textos selecionados foram divulgados pelo jornal entre os dias 27 de novembro de 2012 e 4 de março de 2013. O dia 27 de novembro não é uma data aleatória. Neste dia, começou a $18^{\mathrm{a}}$ Conferência das Partes (COP 18) da Organização das Nações Unidas (ONU), em 2012. A Conferência das Partes (COP) ocorre todos os anos desde 1995 e tem relevância mundial para as discussões sobre o Meio Ambiente.

Nessas conferências foram tomadas decisões cruciais no âmbito da Convenção sobre Diversidade Biológica. A mudança climática é tema recorrente nessas reuniões, tanto que, nos textos da Folha de São Paulo, a COP, muitas vezes, é denominada Conferência Mundial do Clima. Textos dessa natureza são de divulgação científica, entendida por Zamboni (2001, p.48) como "difusão de conhecimentos técnicos ou científicos", com exceção da divulgação feita para os pares de um mesmo círculo científico ou técnico.

A escolha por textos de divulgação científica deve-se à característica dos textos de difusão, que usam uma linguagem mais direta e objetiva, já que o receptor da informação é, em geral, o leigo que não domina conhecimentos especializados de determinada área técnica ou científica. Todavia, ainda que o tema Meio Ambiente seja bastante divulgado, é raro encontrar termos equivalentes na LSB, e, quando existem os sinais nesta língua, muitas vezes, são mal construídos, ou por terem sido criados sem o entendimento do conceito, ou por serem criados por pessoas sem a fluência da LSB como primeira língua.

Os termos recolhidos na pesquisa foram selecionados manualmente, uma vez que lemos cada um dos 62 textos da subcategoria Ambiente que estavam no período estipulado para a pesquisa. Após a seleção dos termos, os dados foram organizados na tabela Excel em ordem alfabética, para criação das fichas lexicográficas.

\subsubsection{Criação de fichas lexicográficas em LP dos termos selecionados}

As fichas lexicográficas seguiram o modelo de Faulstich (2010, p. 184), também componente do roteiro para avaliação de dicionários e glossários científicos e técnicos de Faulstich (2011, p. 182-183).

Os itens que compõem a ficha lexicográfica (Faulstich, 2010) são:

1. entrada;

2. categoria gramatical;

3. gênero;

4. sinônimo;

5. variante; 
6. área de conhecimento ou domínio;

7. definição;

8. fonte da definição;

9. contexto;

10. fonte do contexto;

11. remissivas;

12. nota;

13. equivalentes;

14. autor (a);

15. redator (a); e

16. data.

Cada campo da ficha lexicográfica segue explicado. Faulstich $(2010$, p. 180 - 183) esclarece cada um dos elementos da microestrutura do verbete em LP: A entrada é uma "unidade linguística que possui o conteúdo semântico da expressão terminológica na linguagem de especialidade. É o termo propriamente dito, o termo principal.” (p.180). A categoria gramatical é o "indicativo da classe gramatical ou da estruturação sintáticosemântica do termo. Pode ser s. = substantivo ou n. = nome; v. = verbo; utc $=$ unidade terminológica complexa" (p.180). O gênero é o "indicativo do gênero a que pertence o termo na língua descrita, como $\mathrm{m}=$ masculino ou $\mathrm{f}=$ feminino" (p.180). A variante é definida como "formas concorrentes com a entrada. As variantes correspondem a uma das alternativas de denominação para um mesmo referente. Elas podem ser variantes terminológicas linguísticas e variantes terminológicas de registro" (p.180-181). O sinônimo é definido como "formas coocorrentes no discurso da linguagem de especialidade cujo significado é idêntico ao termo da entrada” (p.181). A área de conhecimento ou domínio é o “ indicativo da área científica ou técnica em que o termo é usado." "A definição é um sistema de distinções recíprocas que servem para descrever conceitos pertinentes aos termos" (p.181). A fonte da definição é o "registro do nome do autor, da obra, data, etc. de onde foi compilada a definição. O campo deve ser preenchido mesmo que o autor do dicionário ou glossário seja o autor ou adaptador das definições" (p.181). O contexto é definido como "um fragmento de texto no qual o termo principal aparece registrado, transcrito com o fim de demonstrar como é usado na linguagem de especialidade" (p.181). A fonte do contexto é o " registro do autor, obra, data, etc. de onde foi extraída a frase contextual, também chamada de abonação" (p.181). As remissivas são definidas como "sistema de relação de complementaridade entre 
termos. Os termos remissivos se relacionam de maneiras diversas, dependendo da contiguidade de sentido. Podem ser: termos hiperônimos ${ }^{38}$, termo hipônimos ${ }^{39}$ e termos $\operatorname{conexos}^{40 "}$ (p.182). A nota é um “comentário prático, linguístico ou enciclopédico, que serve para complementar as informações da definição" (p.182). Os equivalentes são "termos de línguas estrangeiras que possuem o mesmo referente. Num dicionário, incluem-se os termos equivalentes das línguas selecionadas, segundo o plano da obra" (p.182-183). O autor é o "registro do nome do responsável intelectual pela elaboração da ficha de terminologia; o registro pode ser feito por meio de sigla ou abreviação" (p.183). O redator é o "registro do nome do responsável pelo preenchimento/digitação da ficha de terminologia; o registro pode ser feito por meio de sigla ou abreviação" (p.183); e, finalmente, a data que é o "registro do dia, mês, ano em que a ficha foi preenchida" (p.183).

Em nossa pesquisa, as informações que compõem as fichas em LP são: a entrada, a categoria gramatical, o gênero, a variante (quando houver), a definição, a fonte da definição, o contexto, a fonte do contexto e a remissiva (quando houver). Uma ficha preenchida é demonstrada, a seguir. Antes, relacionamos as abreviações que compõem a ficha: s. = substantivo; m. = masculino; DIMA $=$ Dicionário Ilustrado de Meio Ambiente e CBN = Cristiane Batista do Nascimento.

\footnotetext{
${ }^{38}$ Hiperônimo: "Termo cujo significado inclui o significado de outros, por isso é também chamado de termo genérico. Num dicionário ou glossário, o hiperônimo é, normalmente a expressão léxica que inicia a definição" (FAULSTICH, 2010, p. 182).

${ }^{39}$ Hipônimo: "Termo cujo significado representa uma subclasse em relação ao hiperônimo, por isso é também chamado de termo específico. Num dicionário ou glossário, o hipônimo é o termo que contribui na constituição do conteúdo da definição, por isso pode haver mais de um... A soma do conteúdo semântico do hiperônimo mais a do hipônimo delimita e distingue os conceitos na descrição do termo" (FAULSTICH, 2010, p. 182).

${ }^{40}$ Conexo: "Termo que estabelece relação conceitual externa e estreita entre si. Num dicionário ou glossário o termo conexo surge de uma relação conceitual do termo-entrada com outro que mantenha nexo semântico imediato com ele" (FAULSTICH, 2010, p. 182).
} 
Quadro 3 - Modelo de ficha lexicográfica da área do Meio Ambiente

\begin{tabular}{|c|c|}
\hline Entrada & degelo \\
\hline $\begin{array}{l}\text { Categoria } \\
\text { gramatical }\end{array}$ & S. \\
\hline Gênero & $\mathrm{m}$. \\
\hline \multicolumn{2}{|l|}{ Variante(s) } \\
\hline \multicolumn{2}{|l|}{ Sinônimo } \\
\hline \multicolumn{2}{|l|}{$\begin{array}{l}\text { Área de } \\
\text { conhecimento ou } \\
\text { domínio }\end{array}$} \\
\hline Definição & $\begin{array}{l}\text { Derretimento vagaroso da neve ou do gelo na superfície } \\
\text { terrestre por causa do aumento da temperatura atmosférica } \\
\text { acima de } 0 \mathrm{C} \text {. }\end{array}$ \\
\hline Fonte definição & DIMA \\
\hline Contexto & O degelo recorde no Ártico também recebeu destaque. \\
\hline Fonte contexto & $\begin{array}{l}\text { Disponível } \\
\text { http://www1.folha.uol.com.br/ambiente/1192867- }\end{array}$ \\
\hline Remissivas & gelo; neve \\
\hline \multicolumn{2}{|l|}{$\operatorname{Nota}(\mathrm{s})$} \\
\hline \multicolumn{2}{|l|}{ Equivalente } \\
\hline Autor & $\mathrm{CBN}$ \\
\hline Redator & $\mathrm{CBN}$ \\
\hline Data & $10 / 12 / 2013$ \\
\hline
\end{tabular}

Fonte: Elaborado pela autora seguindo o modelo de Faulstich (2010, p. 184)

A estrutura dos verbetes em LP apresentam a seguinte microestrutura:

$+{ }^{41}$ entrada + categoria + gênero + definição + fonte da definição $\pm^{42}$ variante $(s) \pm$ remissiva(s)

Um dos problemas encontrados na recolha de contexto foi que as informações, na maior parte, não contribuíam com a elucidação dos conceitos, além de alguns serem extensos e pouco ilustrativos, fora do contexto completo da matéria do jornal. Como já mencionamos, a LP não é a língua que a maioria dos surdos domina e um contexto que não informa não servirá para a compreensão da LP pelos estudantes surdos. Dessa forma, os contextos não são parte do verbete, embora estejam presentes nas fichas.

\footnotetext{
${ }^{41}$ Legenda: + significa que o elemento é obrigatório no verbete.

42 Legenda: \pm significa que o elemento é opcional, quando houver.
} 


\subsubsection{Busca de definições dos termos em obras lexicográficas e terminográficas de referência}

As obras lexicográficas e terminográficas consultadas, das quais foram compiladas as definições da área do Meio Ambiente, são as seguintes:

- DIMA - Dicionário Ilustrado de Meio Ambiente, 2012;

- GBNDES - Glossário de termos usados em atividades agropecuárias, florestais e ciências ambientais, compilado por José Geraldo Pacheco, 2006;

- VIBGE - Vocabulário Básico de Recursos Naturais e Meio Ambiente, 2004;

- VAI - Vocabulário Ambiental Infantojuvenil, 2013.

- DH - Dicionário Houaiss, 2009; e

- $\mathrm{AD}$ - Aulete Digital, 2008.

As abreviações que antecedem os títulos das obras servem como indicação nas fichas lexicográficas (Apêndice B).

As definições extraídas dessas obras apresentam grau de confiabilidade, porque são obras lexicográficas vinculadas a instituições de renome no País e satisfazem a pertinência dos termos selecionados para o glossário de Meio Ambiente LSB-LP, porque há coerência entre termos e definições. Contudo, as definições passaram por reformulação, prevista nos procedimentos dessa pesquisa. Discorremos sobre a reformulação das definições na seção subsequente.

\subsubsection{Reformulação das definições extraídas de materiais lexicográficos existentes e adaptação da linguagem ao público-alvo}

A fim de reformular as definições retiradas de seis obras lexicográficas de forma sistemática, elaboramos um método coerente de reformulação das definições para o glossário. Para compreensão desse método é necessário apresentarmos o postulado de Finatto (2011).

O modelo de decomposição de interpretantes que propomos tem como base o trabalho de Finatto (2001, p. 218). A autora postulou que os predicados "SER incl", "SER qual", "POSSUIR", "FAZER", "SERVIR para" e "RESULTAR de" poderiam ser depreendidos das definições terminológicas e, com isso, auxiliaria a verificação e crítica das definições com o objetivo de obter maior homogeneidade lógico-semântica. Entretanto, Finatto não esclarece em seu artigo o que entende por SER incl, SER qual, POSSUIR, FAZER, SERVIR para e 
RESULTAR de. Esta omissão dificulta a reestruturação das definições a partir das categorias verbais postuladas por ela.

Tendo em vista essa lacuna, definimos a seguir como compreendemos, neste trabalho, cada uma das categorias verbais sistematizadas por Finatto. A categoria "SER incl" vai responder à pergunta “o que é?". A categoria "SER qual” diz respeito às características qualificativas do SER, como cor, formato, tamanho, estados da matéria etc., em geral, o "SER qual" corresponde aos argumentos por meio de adjetivos. A categoria "POSSUIR" informa o que o objeto tem ou contém. Nesta categoria também é possível definir algo pela ausência de algum elemento ou parte de um organismo, caso a ausência seja uma informação importante para o entendimento do conceito. A categoria "FAZER" explicita o que algo ou alguém faz, a ação produzida por uma pessoa, um animal etc. A categoria "RESULTAR de" diz respeito às informações como: é consequência de, causado por, resultado de ou efeito de. E na última, "SERVIR para”, compreendemos como em Faulstich (2014), é a explicação de para que serve o objeto.

Os predicados SER incl, SER qual, POSSUIR, FAZER, SERVIR para e RESULTAR de foram o caminho encontrado por nós para dar maior uniformidade aos verbetes. Estes são utilizados para definir os limites de um conceito terminológico. Todavia, em vez de partir de contextos, como textos e artigos da área, partimos das definições existentes e as decompusemos em proposições como as que são demonstradas nas fichas de reestruturação das definições, conforme pode ser conferido nos quadros (04, 05, 06 e 07), a seguir.

Quadro 4 - Ficha de reformulação de alga

\begin{tabular}{|c|c|}
\hline \multirow{2}{*}{\multicolumn{2}{|c|}{$\begin{array}{l}\text { Número da ficha: } 8 \\
\text { Termo: alga }\end{array}$}} \\
\hline & \\
\hline \multicolumn{2}{|c|}{$\begin{array}{l}\text { Definição original: Planta aquática cujo habitat são os mares, rios ou lagos e pode ter } \\
\text { dimensões extremamente variadas, de tamanho microscópico até centenas de metros. } \\
\text { Pode permanecer fixa às rochas ou se localizar em meio ao plâncton... Além de } \\
\text { servirem de abrigo e alimento para os animais marinhos e para o ser humano, as algas } \\
\text { também são importantes filtros das águas do mar. (DIMA) }\end{array}$} \\
\hline \multicolumn{2}{|c|}{ Decomposição da definição } \\
\hline SER incl & Planta aquática. \\
\hline SER qual & $\begin{array}{l}\text { Dimensões extremamente variadas, de tamanho } \\
\text { microscópico até centenas de metros. }\end{array}$ \\
\hline \multicolumn{2}{|r|}{ ( } \\
\hline \multicolumn{2}{|l|}{ FAZER } \\
\hline SERVIR para & $\begin{array}{l}\text { Abrigo e alimento para os animais marinhos e para o ser } \\
\text { humano, filtrar as águas do mar. }\end{array}$ \\
\hline RESULTAR de & \\
\hline
\end{tabular}


Quadro 5 - Ficha de reformulação de catador de lixo

\section{Número da ficha: 25}

Termo: catador de lixo

Definição original: Pessoas que trabalham na coleta de lixo para reciclagem. Com o aumento nos índices de desemprego, muitas pessoas excluídas socialmente encontraram uma maneira de sobreviver com a coleta de resíduos. Esses trabalhadores informais geram uma macroeconomia que beneficia a sociedade como um todo apesar de continuarem a ser marginalizados. Os catadores de lixo são indispensáveis, pois separam e fazem a triagem do material que é vendido. DIMA adapt. por CBN

Decomposição da definição

\begin{tabular}{l|l} 
SER incl & Pessoas que trabalham na coleta de lixo
\end{tabular}

SER qual

POSSUIR

FAZER separam e fazem a triagem do material que é vendido para reciclagem

SERVIR para

RESULTAR de

Definição reformulada: Pessoa que trabalha na coleta de lixo para separar e selecionar material para reciclagem.

Fonte: Elaborado pela autora

Quadro 6 - Ficha de reformulação de leopardo

\section{Número da ficha: 82}

Termo: leopardo

Definição original: Grande felino da África e Ásia (Pantherapardus), de hábitos noturnos e pelagem amarela com manchas negras de diversos formatos.AD

Decomposição da definição

\begin{tabular}{|l|l|}
\hline SER incl & felino \\
\hline SER qual & Grande \\
\hline POSSUIR & pelagem amarela com manchas negras de diversos formatos \\
\hline FAZER & \\
\hline SERVIR para & \\
\hline RESULTAR de & \\
\hline
\end{tabular}

Definição reformulada: Grande felino que tem pelos amarelos com manchas negras de diversos formatos. 
Quadro 7 - Ficha de reformulação de melanismo

\begin{tabular}{|c|c|}
\hline \multirow{2}{*}{\multicolumn{2}{|c|}{$\begin{array}{l}\text { Número da ficha: } 93 \\
\text { Termo: melanismo }\end{array}$}} \\
\hline & \\
\hline \multicolumn{2}{|c|}{$\begin{array}{l}\text { Definição original: Escurecimento da pele, plumagem ou pelagem de animais } \\
\text { decorrente da produção muito alta e anormal da melanina. Os indivíduos com excesso } \\
\text { de melanina são chamados melânicos. Um exemplo de indivíduo melânico é a onça- } \\
\text { preta que, na verdade, pertence à espécie de onça-pintada, mas apresenta mais melanina } \\
\text { na pele, o que lhe confere uma coloração escura. DIMA }\end{array}$} \\
\hline \multicolumn{2}{|c|}{ Decomposição da definição } \\
\hline SER incl & Escurecimento da pele, plumagem ou pelagem de animais \\
\hline \multicolumn{2}{|l|}{ SER qual } \\
\hline \multicolumn{2}{|l|}{ POSSUIR } \\
\hline \multicolumn{2}{|l|}{ FAZER } \\
\hline \multicolumn{2}{|l|}{ SERVIR para } \\
\hline RESULTAR de & produção muito alta e anormal da melanina \\
\hline
\end{tabular}

Fonte: Elaborado pela autora

Nesses quadros, mostramos os passos que a definição original percorreu até a definição reformulada. No primeiro campo, apresentamos o número da ficha de reformulação da definição. No segundo, apresentamos o termo que terá a definição reformulada. Em seguida, a parte denominada definição original é o espaço para registrar a definição compilada da(s) obra(s) lexicográfica(s), com a abreviação da(s) fonte(s) ao final. Depois, segue o campo com o sistema de decomposição de interpretantes, denominado "decomposição da definição", e deste campo fazem parte as categorias verbais SER incl, SER qual, POSSUIR, FAZER, SERVIR para e RESULTAR de.

No campo denominado "definição reformulada", apresentamos o novo texto da definição, a partir da decomposição em proposições do texto original, no intuito de alcançar definições padronizadas; nesta parte, reescrevemos, sempre que possível, o texto da definição original numa linguagem mais simples em LP para torná-la mais acessível aos surdos. Além disso, observarmos a linguagem mais adequada para faixa etária e quão específicas devem ser as informações para os estudantes do Ensino Fundamental II. Para isso, consultamos os livros de Ciências "Projeto Teláris" do $6^{\circ}$ ao $9^{\circ}$ de Gewandsznajder (2015), indicado pela coordenadora pedagógica da editora deste livro, que serviu de parâmetro para nivelar que informações são adequadas para o Ensino Fundamental II.

É importante observar nas fichas preenchidas que as definições não precisam preencher todas as seis categorias verbais. Para profissões, por exemplo, podem ser preenchidas apenas as categorias SER incl e FAZER, já para processos podemos preencher as 
categorias SER incl, SER qual, SERVIR para e RESULTAR de, para definição de um animal podemos selecionar as categorias SER incl, POSSUIR e FAZER. A seleção das categorias depende das informações fornecidas nas definições extraídas das obras consultadas em que buscamos as informações mais relevantes do objeto.

Apesar de Finatto (2001, p. 218) advertir sobre as dificuldades de se reduzir textos definitórios, quando afirma que "a redução de determinado conjunto verbal a uma categoria gera um procedimento bastante falho, visto que não se pode sistematizá-lo suficientemente.", a autora ressalta que a análise predicativa contribui bastante para sistematização das definições.

Concordamos que as categorias e o método adotado na reformulação das definições auxiliou a padronização dos verbetes, tanto em relação aos conteúdos, porque destaca as informações mais relevantes do conceito, quanto em relação à padronização da extensão das definições. Isto porque o excesso de informações contidas nos verbetes é eliminado ou ao menos questionado se é uma informação que deve continuar ou não na definição. Ainda que em muitos momentos seja difícil encaixar o texto definitório nas categorias verbais mencionadas, o método coloca em evidência as informações que de fato podem contribuir na compreensão dos termos.

Reiteramos que elaboramos um glossário de termos para surdos matriculados no Ensino Fundamental II, constituído por Temas Especiais ${ }^{43}$. As informações que compõem a obra possuem o intuito informativo e educativo. Com isso, desejamos o entendimento de conteúdo escolar e do cotidiano. Por outro lado, é preciso estar atento ao que afirma Emir José Suaiden, na apresentação do livro "Vocabulário ambiental infantojuvenil", de Maia (2013), que bem observou o cuidado com o reducionismo do conceito na definição:

A definição de termos técnicos para crianças é desafiadora, pois nunca é completa e sempre haverá algo a mais a se perguntar sobre tal definição. Ao se perseguir a clareza e a simplicidade na tentativa de dizer verbalmente um conceito, contornando a sua complexidade técnica, abre-se mão do detalhamento minucioso do seu significado. Mas isso deve ser feito com cuidado para que a simplicidade não prejudique a completude do conceito.

\footnotetext{
${ }^{43}$ Os Temas Especiais são "temas sociais contemporâneos que contemplam, para além da dimensão cognitiva, as dimensões política, ética e estética da formação dos sujeitos, na perspectiva de uma educação humana integral. Dessa forma sua abordagem nas propostas curriculares objetiva superar a lógica da mera transversalidade, ao se colocarem como estruturantes e contextualizadores dos objetivos de aprendizagem." BNCC (2016, p. 47-48)
} 
Mediar o vocabulário terminológico com o uso de uma linguagem mais simples é um grande desafio, já que as áreas de especialidade têm por característica um vocabulário denso e repleto de nomes científicos. Servem de exemplos, as áreas de Botânica e Zoologia com a nomenclatura científica usada para classificar plantas e animais. Além disso, para compreender alguns conceitos, dependemos do conceito de outros termos, quase sempre desconhecidos.

Com o objetivo de tornar os verbetes mais acessíveis aos surdos, buscamos criar definições que apresentem linguagem de especialidade mediada pelo uso do léxico comum como estratégia de compreensão, para alcançar o maior número de consulentes, assim como sistematicidade, tanto em relação ao conteúdo, quanto em extensão, e frases curtas com informações sucintas que contenham as informações mais relevantes do conceito.

Cabe, neste momento, discutir como compreendemos a área de Meio Ambiente e as implicações que esta compreensão tem na seleção e escolha de termos que compõem o glossário. Este esclarecimento justifica-se porque nem entre os especialistas há um consenso da acepção do termo Meio Ambiente e quais seriam os limites desta área do conhecimento.

É importante ter em mente que o produto final, o glossário ilustrado, é um material para uso escolar e, por isso, precisa estar em concordância com as perspectivas das políticas educacionais que regem a educação básica no Brasil. Para isso, fundamentamo-nos nas propostas desta Política Nacional de Educação que rege a Educação Ambiental (EA), sendo assim, tomamos como fundamento a Lei $\mathrm{n}^{0}$ 9.795/1999, que dispõem sobre a educação ambiental e institui a Política Nacional de Educação Ambiental (PNEA).

Em consonância com a legislação vigente, no Art. $4^{\circ}$, inciso II, da referida Lei, fica clara a visão holística que deve nortear o entendimento do conceito de Meio Ambiente quando apresenta como princípio básico da educação ambiental "a concepção do meio ambiente em sua totalidade, considerando a interdependência entre o meio natural, o sócioeconômico e o cultural, sob o enfoque da sustentabilidade".

Também, apresentamos alguns argumentos com base nos Parâmetros Curriculares Nacionais (PCN) que trazem concepções e discussões frente às questões ambientais .

De acordo com o PCN do Meio Ambiente (1997, p. 25), o termo Meio Ambiente encontra-se em construção e vem sendo compreendido como:

... um "espaço"... em que um ser vive e se desenvolve, trocando energia e interagindo com ele, sendo transformado e transformando-o. No caso dos seres humanos, ao espaço físico e biológico soma-se o "espaço" sociocultural. Interagindo com os elementos do seu ambiente, a humanidade 
provoca tipos de modificação que se transformam com o passar da história. E, ao transformar o ambiente, os seres humanos também mudam sua própria visão a respeito da natureza e do meio em que vive.

Ainda sobre o tema, o PCN (1998, p. 201) esclarece que "ambiente é também uma construção humana, sujeito a determinações de ordem não apenas naturais, mas também sociais". E continua neste mesmo documento a explicar que os aspectos sociais, culturais, econômicos e políticos inter-relacionados também fazem parte do escopo da área de Meio Ambiente, de acordo com o PCN (1998, p. 229).

Nos PCNs sobre Meio Ambiente, fica clara a complexidade da temática e os inúmeros aspectos que interferem nesta área de conhecimento. Segundo o PCN (1997, p. 25), a principal função de se estudar o tema Meio Ambiente é contribuir para a formação de cidadãos conscientes que possam interferir positivamente na realidade com vista a manter toda diversidade de vidas e ambientes em equilíbrio.

E para se compreender toda a complexidade desta área, a visão mais ampliada do conceito de Meio Ambiente, que engloba tanto o mundo natural quanto o mundo construído pelos seres humanos, é a defendida pelo PCN (1998, p. 234). Ainda discorrendo sobre esta complexidade que envolve a temática, o $\operatorname{PCN}(1997$, p. 33) apresenta a reflexão a seguir:

Tratar a questão ambiental, portanto, abrange toda a complexidade da ação humana: se quanto às disciplinas do conhecimento ela é um tema transversal, interdisciplinar, nos setores de atuação da esfera pública ela só se consolida numa atuação do sistema como um todo, sendo afetada e afetando todos os setores: educação, saúde, saneamento, transportes, obras, alimentação, agricultura, etc.

É nesta acepção mais ampla de Meio Ambiente, mencionada nos PCN e na Lei 9.795, que nossa proposta se insere. E é neste sentido que o sinal-termo MEIO AMBIENTE, criado nesta pesquisa, significa o mundo em que vivemos, pois entendemos que todos os aspectos físicos, biológicos, sociais, históricos, econômicos, entre outros, interferem no Meio.

Dessa forma, por ser uma área que perpassa outras áreas, como declarado no PCN, constitui-se como uma área do conhecimento interdisciplinar. É importante ter em mente que uma visão fragmentada da realidade pode mascarar os reais problemas que afetam o equilíbrio do ambiente e prejudicar a conscientização genuína dos estudantes frente à realidade do mundo que o cerca.

Ainda nesta perspectiva de uma visão menos fragmentada dos conteúdos escolares, a Base Nacional Comum Curricular (BNCC) organiza as áreas de conhecimento em 
Linguagens, Matemática, Ciências da Natureza e Ciências Humanas. Para demonstrar como as disciplinas estão sendo contempladas na BNCC, mostramos como as disciplinas são contempladas no Ensino Fundamental nesta Base. Em Linguagens, os componentes curriculares que compõem esta área são: Língua Portuguesa, Artes, Educação Física e Línguas Estrangeiras Modernas, com a ressalva de que este último componente faz parte apenas do Ensino Fundamental II referente ao $6^{\circ}$ até $9^{\circ}$. A Matemática é considerada como uma área e também como componente curricular. Já a área Ciências da Natureza do Ensino Fundamental tem como componente curricular Ciências. Apenas no Ensino Médio as Ciências da Natureza se dividem nos seguintes componentes curriculares: Biologia, Física e Química. Por último, a área Ciências Humanas tem como componentes curriculares História, Geografia e Ensino Religioso.

Tendo como base os PCNs sobre Meio Ambiente e a BNCC (2016), percebemos que nossas políticas educacionais caminham para uma visão mais interligada dos conhecimentos, o que favorece uma visão menos fragmentada da realidade. Desejamos caminhar por esta visão interligada de que o ser humano é responsável pelo meio em que vive.

\subsection{Etapas desenvolvidas na criação de sinais-termo}

Os procedimentos seguidos para a construção da microestrutura em LSB foram os seguintes: organização dos termos em campos temáticos e preparação de materiais visuais para apreensão de conceitos durante as sessões de criação e validação; pesquisa e identificação de termos do Meio Ambiente na LSB; promoção das sessões de criação de sinais-termo; promoção das sessões de validação dos sinais-termo; filmagem dos sinais-termo e armazenagem dos termos em base de dados da LSB, como vemos a seguir.

\subsubsection{Organização dos termos em campos temáticos e preparação de materiais visuais para apreensão de conceitos}

Os termos coletados foram organizados em 12 campos temáticos (Apêndice C), a saber, animal, clima, conceitos e ações positivas, ecologia, genética, grandes biomas do Brasil, lixo e coleta seletiva, lugar, poluentes, problemas ambientais, profissões e vegetal. Como os termos são relacionados, um mesmo termo pode estar em mais de um campo. Para essa organização, contamos com a contribuição de duas professoras especialistas, uma de 
Ciências $^{44}$ e outra de Biologia $^{45}$, para revisarem as categorias criadas e auxiliarem na organização dos termos coletados. Além disso, os 12 campos temáticos tornaram as sessões de criação e validação terminológicas mais produtivas, visto que contribuíram para uma visão interligada dos conceitos por meio das relações estabelecidas entre os termos, quando organizados em campos temáticos e, posteriormente, durante a preparação dos powerpoints em que procuramos relacionar termos conexos com base nas definições extraídas das seis obras lexicográficas mencionadas.

A partir da organização dos termos em campos temáticos, buscamos textos, vídeos, imagens em sites, livros, revistas, entre outros materiais, com objetivo de preparar recursos visuais. Estes recursos foram usados como ferramentas pedagógicas para facilitar o entendimento dos conceitos pelos surdos e também serviram de motivação para criação dos sinais-termo. Recorremos, nesta etapa, aos endereços de internet do Ministério do Meio Ambiente, do Instituto Brasileiro do Meio Ambiente e dos Recursos Naturais Renováveis (IBAMA), da Empresa Brasileira de Pesquisa Agropecuária (EMBRAPA), o material do Projeto de Conservação e Utilização Sustentável da Diversidade Biológica Brasileira (PROBIO), site do Greenpeace, do Planeta Sustentável, da Folha do Meio Ambiente, as imagens da WEB, entre outros. Nessa etapa, produzimos powerpoints organizados com base nos campos temáticos cujos slides eram compostos, em geral, por um termo do Meio Ambiente em destaque, com a definição deste termo, ainda sem reformulação, e com imagens da internet que o representassem. O material criado está apresentado nas sessões de criação e de validação.

\subsubsection{Pesquisa e identificação de termos do Meio Ambiente na LSB}

Antes das sessões de criação dos sinais-termo, realizamos pesquisas em um site, dois dicionários e três livros ilustrados. O site analisado foi o "Legenda Libras" de Almeida (2013), os dicionários examinados foram o "Dicionário enciclopédico ilustrado trilíngue Língua de Sinais Brasileira de A a Z" de Capovilla \& Raphael (2001) e o "Dicionário da Língua Brasileira de Sinais de Lira e Felipe” (2006). Os livros ilustrados analisados foram o "Livro ilustrado de Língua Brasileira de Sinais: Desvendando a comunicação usada pelas pessoas com surdez" (2009), (2010) e (2011), todos os três da autoria de Honora e Frizanco. Apresentamos a pesquisa dos termos do Meio Ambiente no capítulo 4.

\footnotetext{
${ }^{44}$ Laysa Juntolli foi a professora que nos acompanhou durante todas as sessões de validação.

${ }^{45}$ Gisele Morisson.
} 


\subsubsection{Promoção das sessões de criação e validação de sinais-termo}

Os encontros para a criação de termos ocorreram no Laboratório de Língua de Sinais Brasileira da Universidade de Brasília - LabLibras - e na Escola Bilíngue Libras e PortuguêsEscrito de Taguatinga (EBT). Os participantes das sessões de criação foram os surdos proficientes em LSB, com ensino superior em Letras Libras; a maioria possui curso de pósgraduação completo ou em andamento. Também contamos, em algumas sessões, com a participação de ouvintes que pesquisam ou trabalham com a LSB, contudo, só os surdos puderam criar sinais, porque entendemos que a criação de novos sinais deve ser feita por pessoas que tenham a LSB como primeira língua.

Durante os encontros de criação, muitos sinais foram acrescentados, porque, no decorrer das discussões sobre conceitos, surgiram novos sinais relacionados ao tema pela necessidade de compreender os termos selecionados. Como houve um aumento considerável do número de sinais-termo, estabelecemos que os sinais criados, que não faziam parte da lista dos 168 termos extraídos do jornal Folha de São Paulo (ver Apêndice A), apenas seriam apresentados como entrada do glossário, não havendo definição em LP, nem ilustração do termo.

Os encontros de validação ocorreram em duas turmas da educação básica na EBT. Detalhamos mais os encontros de criação e validação no capítulo 4.

\subsubsection{Filmagem dos sinais-termo}

A filmagem foi um procedimento presente durante as etapas da pesquisa dedicadas ao registro dos sinais-termo. Isso porque, até o momento, a melhor forma de registro para as línguas de sinais é a gravação em vídeo. Esse recurso contribuiu para preservar as informações criadas pelos surdos, em todas as sessões de criação. Os vídeos foram posteriormente usados nas sessões de validação para que os participantes aprovassem, rejeitassem ou opinassem sobre o termo criado. Os sinais que surgiram nas sessões de criação foram filmados com a câmera de um telefone celular, todavia as filmagens definitivas dos sinais-termo foram realizadas por profissionais. 
Para a filmagem profissional, contamos com a participação de dois cinegrafistas ${ }^{46}$ do Centro de Rádio e Televisão (CRTV) da Universidade Católica de Brasília (UCB), que filmaram os sinais criados no estúdio desta universidade. Para as filmagens foram necessários três dias de trabalho nos períodos da manhã e da tarde. No capítulo 4, apresentamos mais detalhes dessa etapa da pesquisa.

\subsubsection{Armazenagem dos termos em LSB}

Figura 28 - Organização das pastas com os sinais-termo, as variantes e os plurais

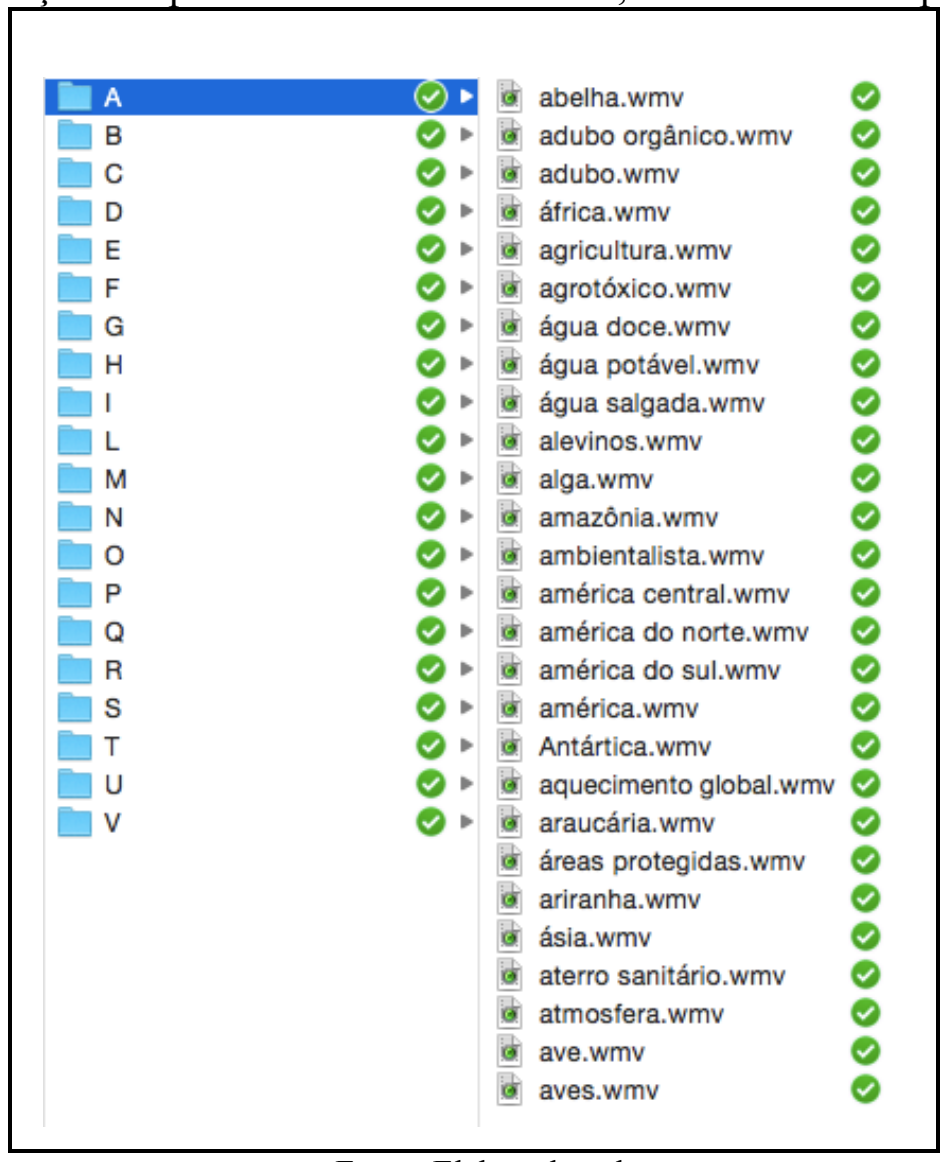

Fonte: Elaborada pela autora

Os sinais-termo do glossário foram armazenados em 20 pastas no computador, como consta na figura 28. As pastas com os vídeos dos sinais ambientais estão organizadas em ordem alfabética; os termos que se iniciam com a letra $\mathrm{A}$ estão todos armazenados na pasta $\mathrm{A}$, os termos que se iniciam com a letra B, encontram-se todos na pasta B e assim

\footnotetext{
${ }^{46}$ Os cinegrafistas desta pesquisa foram Nilton Miranda e Cleidson Dutra. As filmagens foram realizadas no mês de dezembro de 2014.
} 
sucessivamente. Todavia, as pastas com as letras $\mathrm{J}, \mathrm{K}, \mathrm{W}, \mathrm{X}, \mathrm{Y}$ e Z não foram criadas por não haver, nos nossos dados, termos em LP com estas letras iniciais.

\subsection{Criação das ilustrações dos termos do Meio Ambiente e a revisão por especialistas}

As ilustrações do glossário têm a importante tarefa de auxiliar na compreensão das definições em LP, haja vista não haver, até o momento, definição dos termos do Meio Ambiente em LSB. Os desenhos foram criados, por um ilustrador ${ }^{47}$, que tem contato com a comunidade surda, com base nos conceitos retirados das seis obras usadas para a compilação das definições, dos slides confeccionados para as sessões de criação e validação dos sinaistermo e, principalmente, com base nas ideias e orientações de especialistas das Ciências Biológicas e da Biologia. Para isso, algumas sessões de discussões com os especialistas foram necessárias. Nessas sessões, após as discussões, decidíamos como seriam os desenhos.

Ademais, as imagens foram revisadas por especialistas da área para evitar erros de ordem conceitual. Além disso, contamos com a revisão final de um especialista surdo ${ }^{48}$ que revisou o conteúdo das ilustrações, tanto na perspectiva do conceito, quanto, com base na percepção visual dos surdos. Esta última revisão foi essencial para eliminar ou corrigir elementos nas ilustrações que poderiam comprometer o entendimento do consulente surdo. A seguir, apresentamos algumas ilustrações que constarão do glossário.

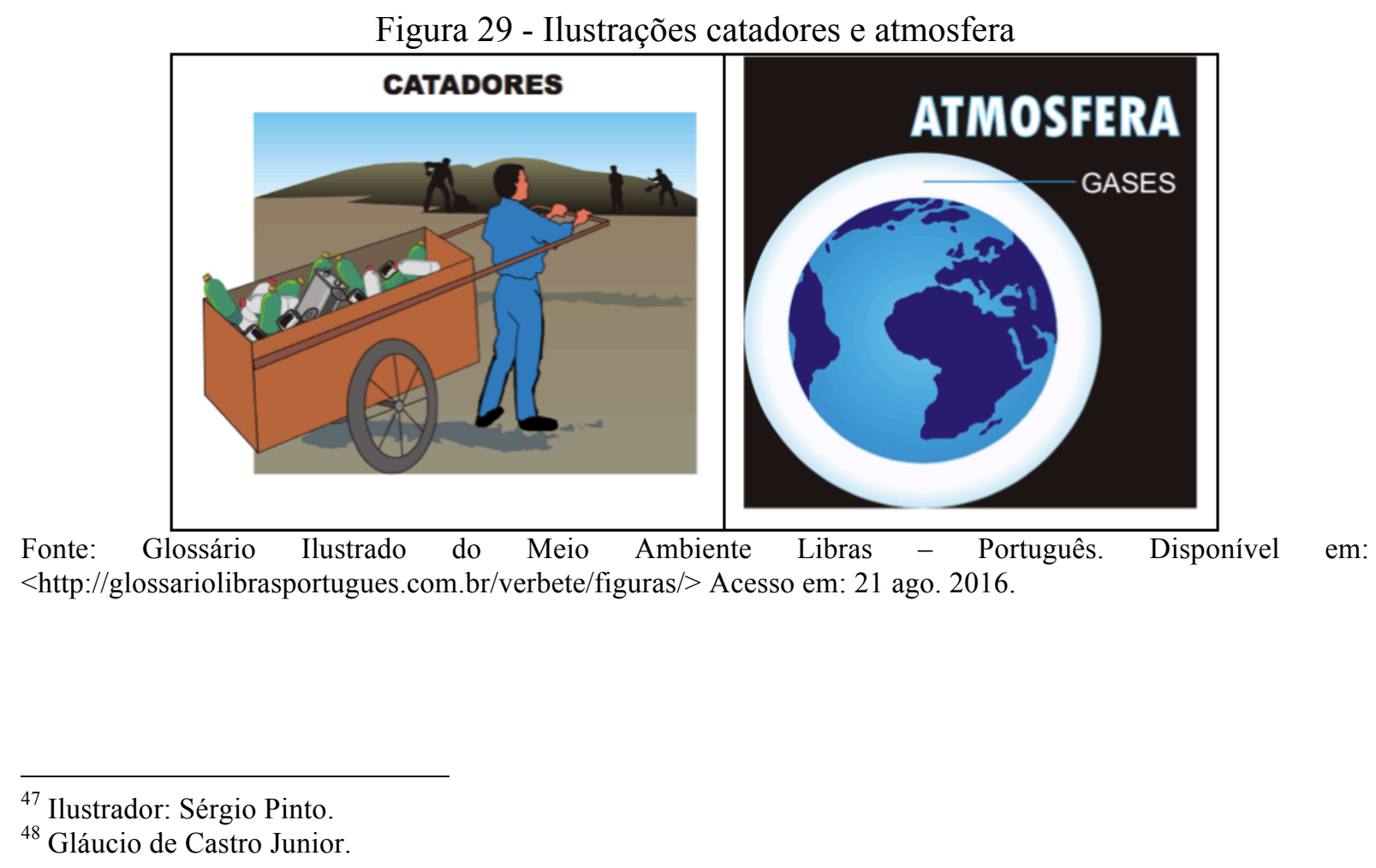


Figura 30 - Ilustrações bactéria e clima

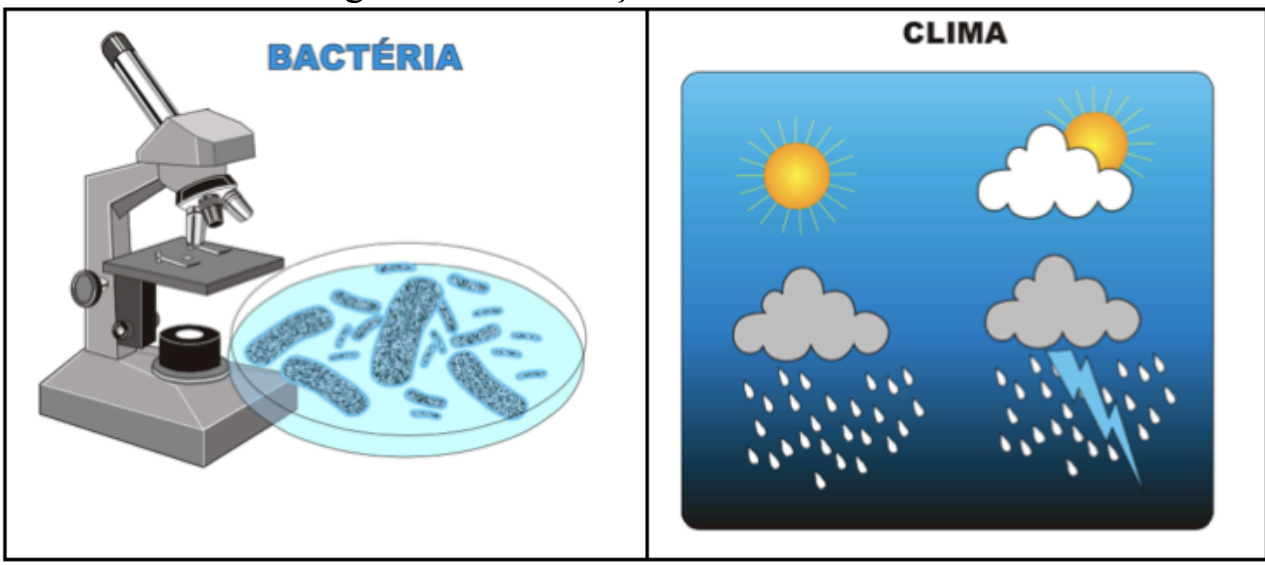

Fonte: Glossário Ilustrado do Meio Ambiente Libras - Português. Disponível em: $<$ http://glossariolibrasportugues.com.br/verbete/figuras/> Acesso em: 21 ago. 2016.

Figura 31 - Ilustrações coleta seletiva e tráfico de animais

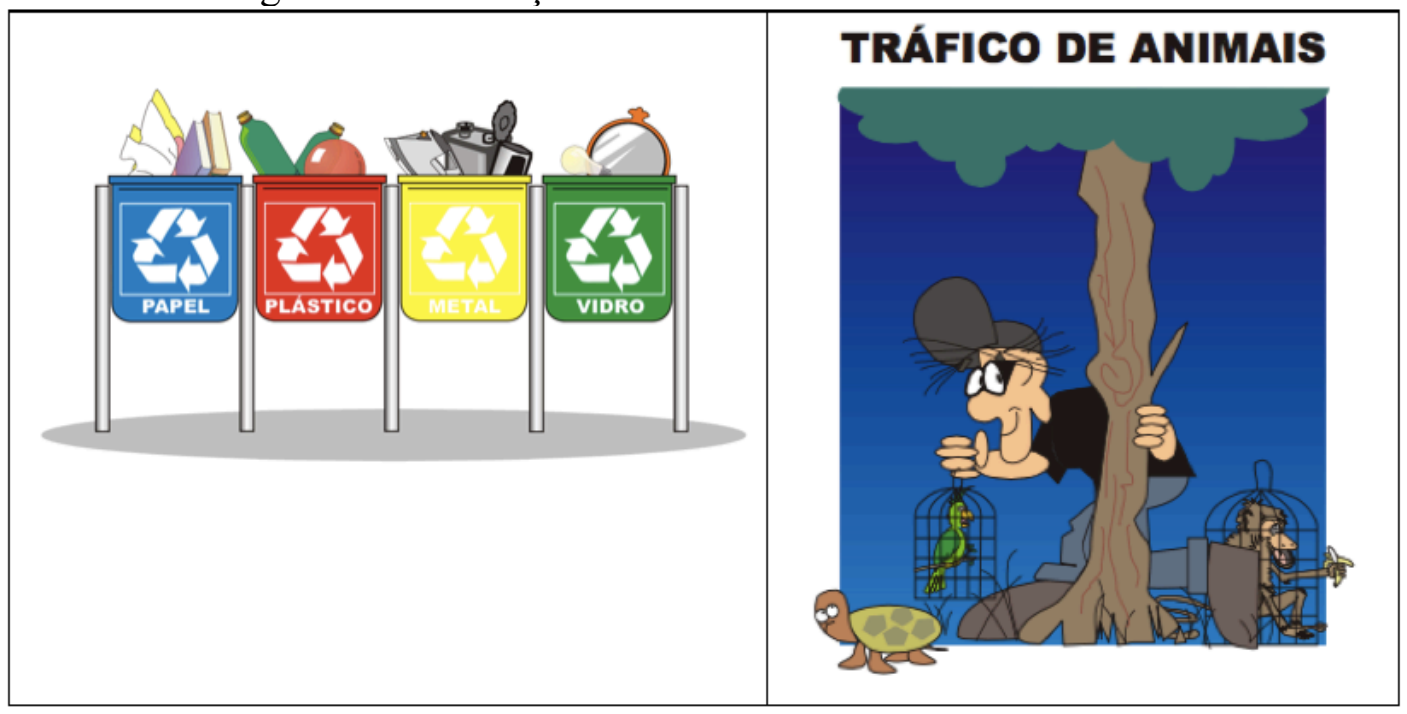

Fonte: Glossário Ilustrado do Meio Ambiente Libras - Português. Disponível em: $<$ http://glossariolibrasportugues.com.br/verbete/figuras/> Acesso em: 21 ago. 2016.

Os quatro últimos procedimentos - desenho do modelo do glossário para criação do suporte em mídia digital, descrição da composição fonológica dos sinais-termo para busca pelo sinal no suporte digital, registro dos dados no suporte digital e divulgação do glossário estão apresentados no capítulo 5.

\subsection{Síntese do capítulo}

Neste capítulo foram apresentados os procedimentos metodológicos para elaboração do glossário. Também discutimos a microestrutura da LP, em especial, o método de reformulação das definições, criado por nós, para manter a sistematicidade das definições e a 
adequação ao público-alvo do nosso glossário. Além disso, mostramos as etapas desenvolvidas na criação dos sinais-termo, bem como descrevemos os procedimentos de filmagem, de armazenagem dos sinais-termo e de criação das ilustrações dos termos do Meio Ambiente. No próximo capítulo, apresentamos os sinais-termo que compõem o glossário, as pesquisas para buscar sinais do Meio Ambiente existentes na LSB e a análise dos sinais criados. 


\section{CAPÍTULO 4: OS SINAIS-TERMO DO GLOSSÁRIO DO MEIO AMBIENTE: MECANISMOS DE CRIAÇÃO DE SINAIS}

\subsection{Introdução}

Neste capítulo, apresentamos os sinais-termo que comporão o glossário do Meio Ambiente. Primeiramente, mostramos as pesquisas realizadas para identificar os sinais do Meio Ambiente existentes e as justificativas para propor ou não um novo sinal. Além disso, apresentamos os sinais que foram criados, as sessões de criação e de validação e os respectivos participantes, uma análise preliminar dos mecanismos de inovação lexical e terminológica da LSB, encontrados nos sinais criados, e as reflexões feitas a respeito das filmagens definitivas dos sinais-termo.

\subsection{Sinais do Meio Ambiente existentes: busca de registro em materiais diversos}

Antes da criação dos sinais-termo do Meio Ambiente, realizamos pesquisas em duas etapas. A primeira etapa foi a busca dos termos do Meio Ambiente existentes na LSB. Para alcançar este propósito, fizemos uma pesquisa intitulada "O léxico da área ambiental na língua de sinais brasileira: busca de mecanismos de designação de termos" de Nascimento e Faulstich (2013). Apresentamos esta pesquisa na seção 4.2.1 deste capítulo.

$\mathrm{Na}$ segunda etapa, para encontrarmos os correspondentes dos termos do Meio Ambiente em LSB, as buscas por termos correspondentes foram direcionadas e delimitadas em 168 palavras extraídas da subseção “Ambiente” do jornal F. São Paulo (Apêndice A). Os demais sinais, que surgiram nas sessões de criação, não fizeram parte da nossa pesquisa de identificação dos sinais do Meio Ambiente já existentes na LSB. Os materiais consultados nesta etapa foram: Livro Ilustrado de Língua Brasileira de Sinais: desvendando a comunicação usada pelas pessoas com surdez (2009), (2010) e (2011), Dicionário da Língua Brasileira de Sinais: LIBRAS versão 2.0 (2006) e o Dicionário Enciclopédico Ilustrado Trilíngue da Língua de Sinais Brasileira - LIBRAS, volume I e II (2001). 


\subsubsection{Busca de sinais do Meio Ambiente no site Legenda Libras}

O primeiro passo para a construção do glossário foi a realização da pesquisa "O léxico da área ambiental na Língua de Sinais Brasileira: busca de mecanismos de designação de termos" $" 49$ de Nascimento e Faulstich (2013). O objetivo desta pesquisa foi recolher termos do Meio Ambiente (MA) em LP e buscar os correspondentes em LSB e, se fosse possível, analisar as estruturas da composição terminológica nesta língua de sinais. Para isso, buscamos textos com a temática do MA, que possuíssem versão nas duas línguas, LP e LSB. Utilizamos o site "Legenda Libras" disponível em http://www.legendalibras.com.br/index.html, que atendia aos dois requisitos: tema do MA e versão do texto nas duas línguas.

Obtivemos como dados da pesquisa 53 termos da área do MA. Estes termos, ao passar pelo processo tradutório da LP para LSB, foram identificados nesta língua de sinais da seguinte forma: em 16 termos foram utilizados o recurso da datilologia (quadro 8) - alfabeto manual da LSB, letra a letra. Em 6 termos, foram utilizados sinais já existentes e datilologia (quadro 9); outros 2 termos foram expressos a partir de fórmulas da química (quadro 10); em mais 12, empregaram-se sinais já existentes para se referir a outro conceito afim (quadro 11); dois novos sinais foram criados (quadro 12) e nos 15 restantes não foram encontradas equivalências (quadro 13), ou porque os conceitos foram diluídos na tradução, ou omitidos do texto, como podem ser conferidos nos quadros a seguir.

\begin{tabular}{|l|l|}
\hline \multicolumn{2}{|c|}{ Quadro 8 - Sinais-digitados } \\
\hline Termo em LP & Glosa em LIBRAS \\
\hline 1. algas & A-L-G-A-S \\
\hline 2. altitude & A-L-T-I-T-U-D-E \\
\hline 3. bentos & B-E-N-T-O-S \\
\hline 4. bioma & B-I-O-M-A \\
\hline 5. biosfera & B-I-O-S-F-E-R-A \\
\hline 6.fitoplâncton & F-I-T-O-P-L-A-N-C-T-O-N \\
\hline
\end{tabular}

\footnotetext{
${ }^{49}$ Pesquisa apresentada no IX ENGTLEX - IX Encontro Intermediário do GT de Lexicologia, Lexicografia e Terminologia da ANPOLL em 2013.

${ }^{50}$ Esta classificação foi convencionada na ocasião da pesquisa para classificar os correspondentes em LSB encontrados na forma de datilologia, a partir da tradução dos textos da LP, apesar de não consideramos a datilologia pura como um sinal.
} 


\begin{tabular}{|l|l|}
\hline 7. fotossíntese & F-O-T-O-S-S-Í-N-T-E-S-E \\
\hline 8. hidrosfera & H-I-D-R-O-S-F-E-R-A \\
\hline 9. gás & G-Á-S \\
\hline 10. latitude & L-A-T-I-T-U-D-E \\
\hline 11. litosfera & L-I-T-O-S-F-E-R-A \\
\hline 12. orca & O-R-C-A \\
\hline 13. sais minerais & S-A-I-S-M-I-N-E-R-A-I-S \\
\hline 14. taiga & T-A-I-G-A \\
\hline 15. tundra & T-U-N-D-R-A \\
\hline 16.zooplâncton & Z-O-O-P-L-A-N-C-T-O-N \\
\hline
\end{tabular}

Fonte: Nascimento e Faulstich (2013)

Quadro 9 - Sinais semidigitados

\begin{tabular}{|l|l|}
\hline \multicolumn{2}{|c|}{ Semidigitados $^{51}$} \\
\hline Termo em LP & Glosa em LIBRAS \\
\hline 1. cactos & CL-espinho-machucar^C-A-C-T-O-S \\
\hline 2. floresta temperada & FLORESTA $^{\wedge}$ T-E-M-P-E-R-A-DA \\
\hline 3. florestas tropicais & FLORESTA $^{\wedge}$ T-R-O-P-I-C-AL \\
\hline 4. gordura & OLEO $^{\wedge}$ G-O-R-D-U-R-A \\
\hline 5. impala & CL chifres-na-cabeça $^{\wedge}$ I-M-P-A-L-A \\
\hline 6. leão-marinho & LEÃO $^{\wedge}$ M-A-R-I-N-H-O \\
\hline
\end{tabular}

Fonte: Nascimento e Faulstich (2013, p. 3)

Quadro 10 - Sinais-siglas

\begin{tabular}{|c|c|}
\hline \multicolumn{2}{|c|}{ Sinais-siglas $^{52}$} \\
\hline Termo em LP & Glosa em LIBRAS \\
\hline 1. gás carbônico & $\mathrm{CO} 2$ \\
\hline 2. oxigênio & $\mathrm{O} 2$ \\
\hline
\end{tabular}

Fonte: Nascimento e Faulstich (2013, p. 3)

\footnotetext{
51 “Os sinais semidigitados apresentam um sinal ou classificador (CL) que recebe um complemento com o uso da datilologia, este mecanismo contribui para especificar o referente.” Nascimento e Faulstich (2013, p. 3).

${ }^{52}$ Sinais motivados por siglas, símbolos, fórmulas químicas, entre outros.
} 
Quadro 11 - Sinais reutilizados

\begin{tabular}{|l|l|}
\hline \multicolumn{2}{|c|}{ Sinais reutilizados } \\
\hline Termo em LP & Glosa em LIBRAS \\
\hline 1. crocodilos & JACARÉ \\
\hline 2. fauna & ANIMAIS \\
\hline 3. flora & PLANTA \\
\hline 4. hibernar & DORMIR \\
\hline 5. oceano & MAR \\
\hline 6. regiões & LUGAR ${ }^{3 x}$ \\
\hline 7. seres vivos & VIDA ou ANIMAIS \\
\hline 8. sólido & DURO \\
\hline 9. solo & ESPAÇO/ÁREA \\
\hline 10. tartaruga-de-pente & TARTARUGA \\
\hline 11. Terra & MUNDO \\
\hline 12. estrelas-do-mar & ESTRELA \\
\hline
\end{tabular}

Fonte: Nascimento e Faulstich (2013, p. 3)

Quadro 12 - Sinais criados

\begin{tabular}{|l|l|}
\hline \multicolumn{2}{|c|}{ Sinais criados } \\
\hline Termo em LP & Glosa em LIBRAS \\
\hline 1. atmosfera & CM em A fazendo um arco como se fizesse um semi-círculo \\
\hline 2. ecossistema & árvore balançando \\
\hline
\end{tabular}

Fonte: Nascimento e Faulstich (2013, p. 4)

\footnotetext{
${ }^{53}$ Sinais já existentes usados na tradução como sinônimos, ou como extensão do significado ou como um sinal genérico. É válido ressaltar que alguns desses termos podem ser considerados como equivalentes no léxico comum, entretanto, no léxico especializado não podem ser compreendidos como sinônimos sem perda de informações.
} 
Quadro 13 - Sinais diluídos na tradução

\begin{tabular}{|l|l|l|l|}
\hline \multicolumn{4}{|c|}{ Sinais diluídos } \\
\hline 1. ambiente & 5. crustáceo & 9. herbívoros & 13. ouriços-do-mar \\
\hline 2. ambiente aquático & 6. espécie & 10. microscópicas & 14. vegetação \\
\hline 3. cadeia alimentar & 7. esponja & 11. molusco & 15. urso polar \\
\hline 4. campos & 8. hemisfério & 12. onívoros & \\
\hline
\end{tabular}

Fonte: Nascimento e Faulstich (2013, p. 4)

O que percebemos nesta pesquisa no site "Legenda Libras" é que a datilologia tem sido um recurso frequente da LSB para expressar os termos encontrados em LP e, por isso, muitos dos sinais usados na tradução são genéricos no detalhamento das informações, consequentemente, o conceito do termo original se torna superficial.

\subsubsection{Busca de sinais nos livros ilustrados e nos dicionários da LSB}

Nesta seção, apresentamos a análise dos livros ilustrados e dos dicionários da LSB pesquisados para identificar sinais do Meio Ambiente que constam da lista do Apêndice A. Para sistematizar a análise, classificamos os sinais encontrados nas obras da seguinte forma: alterados, inalterados e variantes.

Os sinais que permaneceram os mesmos após as sessões de criação foram classificados como inalterados. Por outro lado, os sinais que sofreram alguma modificação foram classificados como alterados. Já os termos da LP, que admitiram mais de um sinal da LSB para denominar o mesmo conceito, passaram por votação para decidir qual das formas existentes ocuparia a função de sinal-termo e qual ocuparia a função de variante. Outra responsabilidade dos participantes das sessões de validação, foi decidir se a forma variante deveria estar ou não no glossário. Os sinais que não ocuparam a função de sinal-termo, mas

\footnotetext{
${ }^{54}$ Os sinais diluídos "são aqueles cujo significado do termo aparece diluído no texto pela tradução, com uso de frases explicativas ou mesmo sendo ignorados durante a transposição de uma língua para outra." Nascimento e Faulstich (2013, p.4)
} 
que foram considerados pertinentes à área do Meio Ambiente foram reconhecidos como sinais variantes.

Os sinais inalterados permaneceram sem nenhuma mudança pelo fato de continuarem sendo considerados pertinentes à área do Meio Ambiente.

A partir das análises dos livros e dos dicionários, classificamos os sinais alterados da seguinte forma: 1) Sinais com pequenas alterações, 2) Sinais modificados para manter a base lexical ou terminológica, 3) Sinais datilológicos substituídos por sinais conceituais e 4) Sinais modificados por inadequação terminológica. Estes últimos ainda foram subdivididos em: a) sinais diferentes do conceito da área do Meio Ambiente, b) sinais em que a especificação do referente não foi considerada adequada e c) sinais inadequados substituídos para atender ao nível formal da linguagem. Também criamos um grupo de sinais que não se enquadram em nenhum dos casos mencionados. A seguir, demonstramos cada um dos tipos de sinais alterados. Ademais é importante notar que esta classificação foi usada na análise dos três livros ilustrados e dos dois dicionários mencionados no início desta seção.

1) Os sinais com pequenas alterações são aqueles que se diferenciam dos sinaistermo, eleitos como entrada do glossário, por uma pequena mudança de movimento, de configuração de mão, perda ou acréscimo de um elemento, que pode ser o acréscimo ou a perda de uma das mãos na sinalização, ou um sinal composto que se torna simples e viceversa.

2) Os sinais modificados para manter a base lexical ou terminológica são aqueles que já possuíam um correspondente em LSB, contudo, foram alterados para que a base lexical ou terminológica fosse mantida e permitisse a dedução dos sinais pela estrutura e por suas relações semânticas.

3) Os sinais datilológicos ${ }^{55}$ substituídos por sinais conceituais são sinais que, originalmente, foram criados a partir da motivação da LP escrita representada na LSB pelo alfabeto manual, que representa as letras da palavra em LP no sinal, geralmente, com acomodação fonológica da língua receptora, no caso a LSB. Essas substituições ocorreram porque, em geral, a datilologia não é um recurso da língua que oferece clareza conceitual e dificilmente servirá de base para criação de outros sinais-termo. Este mecanismo dificulta a transparência da unidade terminológica por sua estrutura arraigada à escrita da LP.

\footnotetext{
${ }^{55}$ Datilologia é a representação manual de um alfabeto de uma língua oral por configurações de mão, formatos que as mãos adquirem na execução dos sinais, de uma língua de sinais.
} 
4) Os sinais modificados por inadequação terminológica são os que revelam conceito diferente da área do Meio Ambiente porque suscitam preconceito ou uma acepção pejorativa ou mesmo porque a referência visual do sinal é inadequada a área de especialidade em questão. Neste último caso, serve de exemplo o sinal GELO, que foi modificado porque o sinal usado no léxico comum faz referência ao gelo para bebidas. A mudança se dá por supressão de um conceito estereotipado, como os encontrados no sinal de JAPÃO, que se refere ao olho puxado, ou do sinal de ÁFRICA, que faz referência ao cabelo afro, ou o sinal de TRADICIONAL, em que o sinal é um quadrado em frente à face, passando a ideia de que o tradicional é antiquado etc. Esses sinais são substituídos para que seja eliminado o traço negativo incorporado ao sinal. Neste grupo, também entram a substituição de sinais que têm aparência de gesto por outros de maior abstração, o que permite um grau maior de formalidade à LSB, como o sinal MAMÍFERO criado nesta pesquisa.

Os sinais que não se enquadram em nenhum dos casos não demonstraram problemas de natureza conceitual e estrutural, apenas não fazem parte da lista dos sinais do glossário, mas não há nada que os desabonem para ocupar o lugar de variantes dos sinaistermo. Alguns sinais nessas condições se tornaram formas variantes do glossário.

Para sistematizar a análise dos sinais do MA encontrados nas obras, criamos um quadro com os sinais das cinco obras pesquisadas. Antes, explicamos as abreviações, as convenções e as informações do quadro de análise dos sinais identificados (quadro 14). Na primeira coluna, apresentamos o sinal-termo ${ }^{56}$ e o número da ficha lexicográfica correspondente à este termo em LP - vale lembrar que as fichas lexicográficas estão disponíveis no Apêndice B. Na primeira linha do quadro estão as Obra 1, Obra 2, Obra 3 e Obra 4 que correspondem respectivamente à Obra 1: Livro ilustrado de Língua Brasileira de Sinais: desvendando a comunicação usada pelas pessoas com surdez (2009) e o de (2010). É necessário esclarecer que consideramos os dois livros juntos porque no livro de 2010, apenas o sinal BACTÉRIA foi identificado; Obra 2: Livro ilustrado de Língua Brasileira de Sinais: desvendando a comunicação usada pelas pessoas com surdez (2011); Obra 3: Dicionário da Língua Brasileira de Sinais: LIBRAS (2006) e Obra 4: Dicionário Enciclopédico Ilustrado Trilíngue da Língua de Sinais Brasileira (2001). Chamamos atenção para o fato de que as ilustrações de como os sinais são produzidos estão todas digitalizadas e organizadas no Anexo (B) e podem ser comparadas com os sinais-termo criados nesta pesquisa (Apêndice D). A

\footnotetext{
${ }^{56}$ No sistema de transcrição de Felipe, os sinais são representados por palavras da Língua Portuguesa com as letras maiúsculas.
} 
exceção é a Obra 3, por se tratar de um dicionário eletrônico e, devido a isso, não tem o registro dos sinais no suporte papel. Porém, uma outra versão dessa mesma obra pode ser encontrada na internet em: http://www.acessibilidadebrasil.org.br/libras/.

Arrolamos, também, as abreviações usadas no quadro: alt = alterada, inal = inalterada e $\mathrm{v}=$ variante. $\mathrm{O}$ " $\mathrm{x}$ " significa que determinada obra tem o sinal-termo marcado, seja na forma alterada, na inalterada ou na forma variante. $\mathrm{O}$ " $\mathrm{xx}$ " significa que existem dois sinais para o mesmo termo e ambos foram alterados em relação ao sinal-termo adotado.

Quadro 14 - Análise dos livros ilustrados e dos dicionários

\begin{tabular}{|c|c|c|c|c|c|c|c|c|c|c|c|c|}
\hline Sinal-termo/no ficha & \multicolumn{3}{|c|}{ Obra 1} & \multicolumn{3}{|c|}{ Obra 2} & \multicolumn{3}{|c|}{ Obra 3} & \multicolumn{3}{|c|}{ Obra 4} \\
\hline & alt & inal & $\mathbf{v}$ & alt & inal & $\mathbf{v}$ & alt & inal & $\mathbf{v}$ & alt & inal & $\mathbf{v}$ \\
\hline AGRICULTURA/3 & & & & & & & $\mathrm{x}$ & & & $\mathrm{x}$ & & \\
\hline BACTÉRIA/15 & $x^{57}$ & & & & & & & & & & & \\
\hline CAMARÃO/22 & & & & & & & $\mathrm{x}$ & & & $\mathrm{x}$ & & \\
\hline CICLONE/26 & & & & & $\mathrm{x}$ & & & & & & & \\
\hline CIENTISTA/27 & & & & $\mathrm{x}$ & & & & & & & $\mathrm{x}$ & $\mathrm{x}$ \\
\hline COMBUSTÍVEL/31 & & & & & & & $\mathrm{x}$ & & & & & \\
\hline COSTA/35 & & & & & & & $\mathrm{x}$ & & & & & \\
\hline ELETRECIDADE/50 & & & & & & & & & & $\mathrm{x}$ & & \\
\hline EROSÃO/51 & & & & & & & & & & $\mathrm{x}$ & & \\
\hline FELINO/56 & & & & & & & & & & $\mathrm{x}$ & & \\
\hline FLORESTA/57 & & & & & & & & $\mathrm{x}$ & & & $\mathrm{x}$ & \\
\hline FOLHA/59 & & & & & & & & $\mathrm{x}$ & & & & \\
\hline FURACÃO/62 & & $\mathrm{x}$ & & $\mathrm{x}$ & & & $\mathrm{x}$ & & & & $\mathrm{x}$ & \\
\hline GÁS/63 & & & & & & & $\mathrm{x}$ & & & & & \\
\hline GELO/64 & & & & & & & $\mathrm{x}$ & & & $\mathrm{x}$ & & \\
\hline ICEBERG/70 & & & & & & & $\mathrm{x}$ & & & & & \\
\hline ILHA/71 & $\mathrm{x}$ & & & & & & $\mathrm{x}$ & & & $\mathrm{x}$ & & \\
\hline $\mathrm{LAGO/76}$ & & & & & & & $\mathrm{x}$ & & & & & \\
\hline LAGOSTA/77 & $\mathrm{x}$ & & & & & & $\mathrm{xx}$ & & & & & \\
\hline LAMA/78 & & & & & & & $\mathrm{x}$ & & & $\mathrm{x}$ & & \\
\hline LAVOURA/79 & & & & & & & $\mathrm{x}$ & & & & & \\
\hline LEOPARDO/80 & & & & $\mathrm{x}$ & & & & & & & & \\
\hline
\end{tabular}

57 O sinal BACTÉRIA foi o único encontrado no Livros Ilustrado de 2010. 


\begin{tabular}{|c|c|c|c|c|c|c|c|c|c|c|c|c|}
\hline \multirow[t]{2}{*}{ Sinal-termo $/ n^{0}$ ficha } & \multicolumn{3}{|c|}{ Obra 1} & \multicolumn{3}{|c|}{ Obra 2} & \multicolumn{3}{|c|}{ Obra 3} & \multicolumn{3}{|c|}{ Obra 4} \\
\hline & alt & inal & $\mathbf{v}$ & alt & inal & $\mathbf{v}$ & alt & inal & $\mathbf{v}$ & alt & inal & $\mathbf{v}$ \\
\hline LIXO/81 & & & & & & & $\mathrm{x}$ & & & & & \\
\hline LULA/82 & & & & $\mathrm{x}$ & & & & $\mathrm{x}$ & & & $\mathrm{x}$ & \\
\hline MAMÍFERO/83 & & & & & & & $\mathrm{x}$ & & & & & \\
\hline $\mathrm{MAR} / 84$ & & $\mathrm{x}$ & & & & & & $\mathrm{x}$ & & & $\mathrm{x}$ & \\
\hline MATA/86 & & & & & & & & & & & $\mathrm{x}$ & \\
\hline METAL/92 & & & & & & & $\mathrm{X}$ & & & & & \\
\hline $\mathrm{MICO} / 93$ & & & & $\mathrm{X}$ & & & $\mathrm{x}$ & & & & & \\
\hline NATUREZA/103 & $\mathrm{x}$ & & & & & & $\mathrm{x}$ & & & $\mathrm{x}$ & & \\
\hline NEVE/104 & $\mathrm{x}$ & & & & & & & $\mathrm{x}$ & & $\mathrm{x}$ & & \\
\hline NUVEM/106 & $\mathrm{x}$ & & & & & & $\mathrm{x}$ & & & $\mathrm{x}$ & & \\
\hline OCEANO/107 & & & & & & & $\mathrm{x}$ & & & $\mathrm{x}$ & & \\
\hline ORGANISMO/110 & & & & & & & $\mathrm{x}$ & & & & & \\
\hline $\mathrm{OVO} / 112$ & $\mathrm{x}$ & & & & & & $\mathrm{XX}$ & & & & & \\
\hline PANDA/115 & & & & & & & & & & $\mathrm{X}$ & & \\
\hline PÁSSARO/118 & $\mathrm{x}$ & & & & & & $\mathrm{XX}$ & & & $\mathrm{xX}$ & & \\
\hline POLUIÇÃO/124 & & & & & & & $\mathrm{x}$ & & & & & \\
\hline POPULAÇÃO/125 & & & & & & & $\mathrm{x}$ & & & & & \\
\hline ROCHA/138 & & & & & & & & & & $\mathrm{x}$ & & \\
\hline SECA/141 & & & & $\mathrm{x}$ & & & & & & $\mathrm{x}$ & & \\
\hline $\mathrm{SOJA} / 145$ & & & & $\mathrm{x}$ & & & & & & & & \\
\hline $\mathrm{SOLO} / 146$ & & & & & & & & & & $\mathrm{x}$ & & \\
\hline TEMPESTADE/153 & $\mathrm{x}$ & & & $\mathrm{x}$ & & & & & & $\mathrm{x}$ & & \\
\hline TERRA/154 & & $\mathrm{x}$ & $\mathrm{x}$ & & & & & $\mathrm{x}$ & & $\mathrm{x}$ & & \\
\hline TIGRE/155 & & $\mathrm{x}$ & $\mathrm{X}$ & & & & $\mathrm{x}$ & & & & & \\
\hline TORNADO/156 & & & & & & & & $\mathrm{x}$ & & & & \\
\hline TUBARÃO/160 & $\mathrm{x}$ & & & & & & $\mathrm{x}$ & & & $\mathrm{x}$ & & \\
\hline TUFÃO/161 & & & & & & & & & & & $\mathrm{x}$ & \\
\hline VEGETAÇÃO/165 & & & & & & & $\mathrm{x}$ & & & & & \\
\hline VENTO/166 & $\mathrm{x}$ & & & & & & $\mathrm{x}$ & & & & & \\
\hline VERDURAS/167 & $\mathrm{X}$ & & & & & & $\mathrm{X}$ & & & & & \\
\hline VERME/168 & & & & & & & $\mathrm{x}$ & & & $\mathrm{x}$ & & \\
\hline
\end{tabular}

Fonte: Elaborado pela autora 


\subsubsection{Obra 1: Livro ilustrado de Língua Brasileira de Sinais: desvendando a comunicação usada pelas pessoas com surdez (2009) e (2010)}

Honora e Frizanco publicaram em 2009, 2010 e 2011, uma coletânea de três livros intitulados "Livro Ilustrado de Língua Brasileira de Sinais: desvendando a comunicação usada pelas pessoas com surdez". Estas obras estão organizadas por temas, todavia para verificar a existência de sinais relacionados ao Meio Ambiente, consultamos o índice remisso, ao final de cada livro, porque o índice é organizado em ordem alfabética. Dessa forma, foi possível encontrar a palavra em LP e a página onde estaria o correspondente em LSB. Cada sinal é apresentado da seguinte forma nos livros: o desenho do sinal, uma ilustração correspondente ao objeto/conceito do sinal e a descrição dos elementos que o compõem, configuração de mão $(\mathrm{CM})$, ponto de articulação (PA), movimento $(\mathrm{M})$, orientação da palma $(\mathrm{O})$ e em alguns casos as expressões não manuais (ENM), faciais e corporais (EF/C), como consta na figura 32.

Figura 32 - Sinal FURACÃO

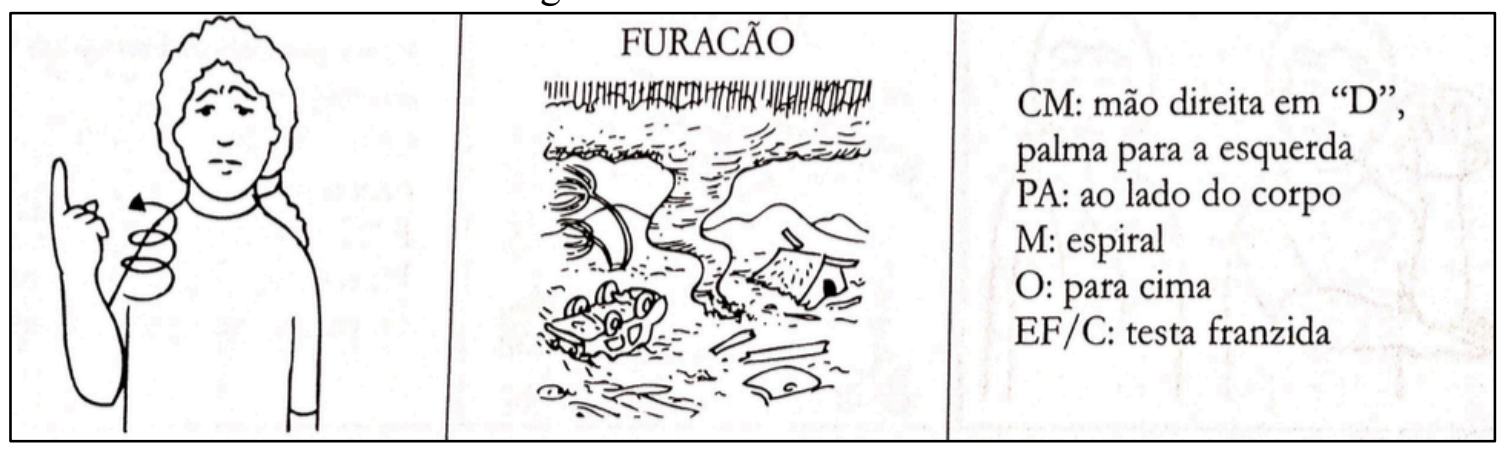

Fonte: Honora e Frizanco (2009, p. 99)

No primeiro livro da coletânea de Honora e Frizanco, identificamos 15 sinais do Meio Ambiente dos 168 que constam em nossa lista (retirados do jornal Folha de São Paulo). O quadro 14, obra 1, mostra que a maioria dos sinais do livro ilustrado (2009) sofreu alguma alteração com exceção dos sinais FURACÃO (p. 99), MAR (p. 100), TERRA (p. 102) e TIGRE (p. 200), que foram classificados como sinais inalterados justamente por serem executados da mesma forma que os sinais-termo do nosso glossário. Esses dois últimos, foram classificados tanto como inalterados quanto como variante porque, para os sinais TIGRE e TERRA, foram criadas formas variantes.

Entre os sinais alterados identificados com pequenas alterações está o sinal de NEVE (p. 101) que, no nosso glossário, tornou-se simples ao perder o sinal FRIO de sua 
composição, o item lexical FRIO tem sido eliminado deste sinal em alguns dialetos da LSB, como o utilizado em Brasília, por exemplo. O sinal VENTO (p. 104) apresenta apenas o movimento diferente, que no livro ilustrado o movimento dos braços é circular, enquanto o sinal da nossa pesquisa apresenta dois movimentos simultâneos, um de braço em que os dois braços se movimentam para o meio e para fora e o outro movimento é de dobrar os pulsos e estendê-los.

Há também o sinal VERDURA (p.159) modificado para manter a base lexical e terminológica. Este sinal, no livro ilustrado, pode ser glosado como ALFACE^DIVERSOS, foi substituído por um sinal que tem a mesma base dos sinais AGROTÓXICO, AGRICULTURA, HORTA, entre outros relacionados ao cultivo da terra. Já o sinal datilológico ILHA (p. 99) foi classificado como alterado porque foi substituído por um sinal conceitual.

Os sinais modificados por inadequação terminológica foram: TEMPESTADE (p. 103), PÁSSARO (p. 196), NATUREZA (p. 96), OVO (p. 153) e LAGOSTA (p. 194). O sinal TEMPESTADE apresenta um conceito diferente da área do Meio Ambiente, para esta área, o termo tempestade se caracteriza por ventos fortes e não há necessariamente precipitação. Os demais sinais não possuem a especificação adequada.

$\mathrm{Na}$ pesquisa do Livro Ilustrado de Língua Brasileira de Sinais: desvendando a comunicação usada pelas pessoas com surdez (2010) identificamos apenas o sinal BACTÉRIA (p. 165), que foi classificado como modificado por inadequação terminológica porque não identificamos nenhuma informação conceitual na estrutura do sinal.

Os sinais TUBARÃO (p. 200) e NUVEM (p. 101) não se enquadram em nenhum dos casos pois não apresentam nenhum problema conceitual ou estrutural. Nesses casos, os validadores decidiam se esses sinais deveriam constar como variante no glossário.

\subsubsection{Obra 2: Livro ilustrado de Língua Brasileira de Sinais: desvendando a comunicação usada pelas pessoas com surdez (2011)}

$\mathrm{Na}$ análise do livro ilustrado (2011), obra 2, identificamos 9 sinais do MA. Apenas o sinal CICLONE foi classificado como inalterado, sem nenhuma mudança em relação aos sinais-termo. As autoras deste livro, Honora e Frizanco, fazem a diferenciação entre o sinal de CICLONE (p. 138) e FURACÃO (p. 138), informação divergente do Dicionário Ilustrado de Meio Ambiente, DIMA, onde trata estes fenômenos como sinônimos. No primeiro livro ilustrado de (2009), o sinal FURACÃO era o mesmo de CICLONE (2011). Mesmo sendo 
livros das mesmas autoras, elas apresentam sinais diferentes tanto para furacão quanto para tempestade. O sinal TEMPESTADE no livro (2011, p. 139) é diferente do sinal criado para o nosso glossário, porém já aparece com o sentido de vento muito forte, como a área do Meio Ambiente concebe.

A substituição de sinais datilológicos por sinais conceituais ocorreu nos sinais datilológicos LULA (p. 222) e SOJA (p. 54). O primeiro foi substituído pelo sinal de LULA já existente na LSB. Já o segundo foi trocado por um sinal criado nas sessões de criação desta pesquisa.

O sinal de LEOPARDO (p. 221) foi alterado para manter a mesma base existente em outros sinais de mesmo campo semântico, por isso foram classificados como modificados para manter a base lexical.

Os sinais modificados por inadequação terminológica foram: o sinal MICO (p. 222) por ser uma construção atípica na estrutura da LSB ao realizar o sinal de MACACO em seguida o sinal PEQUENO, o que não é muito comum, já que, em geral, utilizam as ENM para expressar diminutivos. Os participantes acreditam que o sinal de SECA (p.139) seja mais bem utilizado em outro contexto como o de "roupa seca" e o sinal de CIENTISTA (p. 170) não especifica bem o referente. Já o sinal TEMPESTADE (p. 139) não se enquadra em nenhum dos casos e poderia ser um sinal variante do sinal-termo desta pesquisa.

\subsubsection{Obra 3: Dicionário da Língua Brasileira de Sinais: LIBRAS versão 2.0 (2006)}

O "Dicionário da Língua Brasileira de Sinais: LIBRAS" possui ferramentas para fazer as pesquisas a partir da LP e da LSB, como apresentado no capítulo 2 na seção (2.6.2). A pesquisa neste dicionário foi realizada pela ferramenta denominada "buscar" onde digitávamos a palavra em LP, ou parte dela, para encontrar o correspondente em LSB.

No quadro 14, colunas destinadas à obra 3, identificamos 41 sinais do MA neste dicionário. Os sinais inalterados identificados foram: FLORESTA, FOLHA, MAR, MATA, LULA, NEVE, TERRA e TORNADO.

Já os sinais NUVEM, VENTO, LAGO, FURACÃO, MICO e TUBARÃO, em todos esses houve pequenas alterações no movimento dos sinais. No sinal de PANDA, identificamos uma pequena alteração na perda de uma das mãos no primeiro movimento do sinal. Em TIGRE, identificamos uma alteração na configuração de mão.

Os sinais datilológicos GÁS, ILHA e OVO foram substituídos por sinais criados durante a pesquisa. Já o de LIXO, foi substituído por um sinal existente. Os sinais 
AGRICULTURA, VERDURAS e POLUIÇÃO foram modificados para manter a base terminológica dos sinais-termo criados.

Neste dicionário identificamos 17 sinais existentes que foram modificados por inadequação terminológica, os sinais OCEANO e PÁSSARO são genéricos, já PLANETA, GELO, COSTA são muito específicos e LAVOURA não apresenta o conceito como a área do Meio Ambiente concebe. Já os sinais ORGANISMO, POPULAÇÃO e TEMPESTADE aparecem com outra acepção que não é o do MA. Em VERME, COMBUSTÍVEL, LAGOSTA $2^{58}$, CAMARÃO, NATUREZA, OVO $1^{59}$ e VEGETAÇÃO não foram considerados bons sinais-termo porque não especificam o referente da forma adequada. $\mathrm{O}$ sinal de MAMÍFERO foi substituído por um sinal mais abstrato e formal. Os sinais LAMA, ICEBERG e LAGOSTA não se enquadram em nenhum dos casos. Os sinais nesta última situação foram votados nas sessões de validação para saber se havia preferência por uma das formas, caso não houvesse acordo, a forma menos votada se tornaria variante no glossário mas, em geral, os participantes escolhiam o sinal-termo que consideravam o mais adequado.

\subsubsection{Obra 4: Dicionário enciclopédico ilustrado trilíngue da Língua de Sinais Brasileira}

Este dicionário é organizado em ordem alfabética e possui, ao final do segundo volume, um artigo intitulado "Conteúdo semântico dos sinais da Libras" em que foi possível consultar os sinais a partir dos 31 temas existentes e pela ordem alfabética. Os temas consultados foram: trabalho, natureza, animais, lugares e localidades geográficas. É válido lembrar que apresentamos este dicionário na subseção (2.6.1), capítulo 2.

Apresentamos, no quadro 14, colunas destinada à obra 4, os 30 sinais do MA identificados no dicionário enciclopédico ilustrado trilíngue de Língua de Sinais Brasileira. Os sinais estão classificados como alterado e inalterado, como os demais.

Os sinais inalterados encontrados em Capovilla e Raphael foram: FLORESTA (p. 676), MATA (p. 876), FURACÃO (p. 694), LULA (p. 830), MAR (p. 868), TUFÃO (p. 1278), VERME (p. 1312), CIENTISTA (p. 409) e TERRA (PLANETA) (p. 1246). Estes dois últimos foram classificados tanto como inalterados, quanto como variantes, porque os sinais CIENTISTA e TERRA possuem formas variantes e uma das formas é igual a do sinal-termo.

\footnotetext{
${ }^{58}$ Neste dicionário eletrônico foram apresentados dois sinais para LAGOSTA. O número 2 é uma marcação do próprio dicionário para mostrar que existe mais de um sinal para LAGOSTA.

${ }^{59}$ Marcação do glossário para mostrar que existe mais de um sinal para ovo.
} 
Além disso, identificamos três sinais com pequenas alterações, em NEVE (p. 947), o sinal aparece composto, contudo, tornou-se simples no nosso glossário porque o sinal FRIO foi eliminado deste sinal-termo. Em PANDA, (p. 999) o sinal é quase o mesmo, a diferença é que neste dicionário a execução da primeira parte do sinal é com uma mão na cabeça, que faz referência à orelha do urso e, na segunda parte da composição, as duas mãos fazem referências aos olhos do animal. Todavia, durante as sessões de validação, a preferência foi o uso das duas mãos tanto na cabeça, representando as orelhas, quanto nas duas mãos posicionadas ao redor dos olhos.

Os sinais modificados para manter a base lexical e terminológica identificados foram: AGRICULTURA (p. 167), FELINO (p. 660) e ROCHA ( p. 1149). Também em ILHA (p. 745) houve a substituição deste sinal datilológico por um conceitual.

Além disso, nos sinais classificados/marcados como alterados, identificamos oito sinais modificados por inadequação terminológica que são: OCEANO (p. 969), ELETRECIDADE/ENERGIA ELÉTRICA (p. 575), GELO (p. 706) e PÁSSARO (p. 1016) são sinais genéricos ou específicos demais quando os confrontamos com os conceitos da área do MA. Já os sinais CAMARÃO (p. 344), SOLO (p. 1207) e NATUREZA (p. 941) não foram considerados bons sinais-termo porque não especificam o referente da forma adequada. O sinal de SECA (p. 1172), que é o mesmo que tratamos no livro ilustrado (2011), foi considerado mais adequado em outro contexto. Os sinais EROSÃO (p. 596), LAMA (p. 797), NUVEM (p. 965) e TUBARÃO (p. 1276) não se enquadram em nenhum dos casos. Todavia não foram adotados como variantes do glossário. Isso porque os validadores preferiram o sinal-termo criado em nossa pesquisa.

Como vimos, alguns dos sinais do Meio Ambiente foram encontrados nesses livros e dicionários. Estes podem servir de consulta para os surdos e ouvintes, mas, em geral, são mais úteis aos ouvintes. $\mathrm{O}$ outro fato que precisa ser considerado é que esses sinais são usados no léxico comum. Aqui, por se tratar de uma área de especialidade, alguns sinais foram considerados inadequados, porque não são termos de uma área específica, como é o caso do Meio Ambiente. Para o léxico especializado, foram criados novos sinais que expressam o conceito de forma mais adequada e, assim, podemos evitar a ambiguidade ou superficialidade no conteúdo. 


\subsection{Sessões de criação dos sinais-termo}

As sessões de criação foram encontros para compreensão e discussão de conceitos do Meio Ambiente, com objetivo de criar sinais-termo para o glossário. Essa etapa da pesquisa teve duração de um ano e meio, iniciamos em julho de 2013 e finalizamos no início de dezembro de 2014. Apresentamos, a seguir, o perfil dos participantes desta etapa da pesquisa, as tentativas de sessões de criação com os estudantes surdos da Educação básica, também com os estudantes surdos da Educação de Jovens e Adultos e os procedimentos adotados nas sessões de criação.

\subsubsection{Perfil dos participantes das sessões de criação}

O perfil dos participantes das sessões de criação foi composto por jovens e adultos surdos formados em Letras Libras. O total de participantes que colaboraram nessas sessões foi de nove pessoas. Por demandar muito tempo dos participantes, nunca houve uma sessão que contasse com a presença de todos eles, assim, diversas sessões foram cumpridas com apenas um participante. Também tivemos casos em que os colaboradores contribuíram no começo da pesquisa e depois não puderam continuar, bem como houve participantes que entraram no grupo mais ao final das sessões de criação. Todos os participantes eram fluentes em LSB e com um bom nível de conhecimento de mundo. Este último fator contribuiu bastante para o entendimento dos conceitos e, consequentemente, para a agilidade na criação das novas unidades terminológicas.

Dividimos esses participantes em dois grupos: um que se reunia no LabLibras da UnB e o outro, na Escola Bilíngue Libras e Português Escrito de Taguatinga (EBT).

\subsubsection{Tentativas de sessões de criação com participantes da Educação básica: Ensino Médio e EJA}

Antes de estabelecermos a equipe que constituiria as sessões de criação, fizemos algumas tentativas para desenvolver a pesquisa na educação básica, uma no Ensino Médio e a outra na Educação de Jovens e Adultos - EJA. Estas tentativas visavam garantir sessões de criações com participantes mais assíduos. Fizemos algumas sessões de criação em uma turma 
do $3^{\circ}$ ano do Ensino Médio, durante as aulas de Biologia, juntamente com a professora regente. Infelizmente, as sessões de criação não foram muito produtivas: em 50 minutos de aula, apenas um sinal foi criado.

O mesmo ocorreu com a turma de EJA. As sessões não foram produtivas, porque, em três horas, apenas três sinais foram criados. Apesar de todos os surdos serem adultos, a

defasagem de conhecimentos gerais tornou as sessões de criação pouco produtivas. É importante destacar que é imprescindível o entendimento do conceito antes de se criar um sinal para que a criação siga as regras da formação gramatical e conceitual.

Nestas tentativas de criação na escola, notamos que a influência da LP escrita na criação dos sinais foi muito mais recorrente do que nos surdos com formação superior em Letras Libras.

\subsubsection{Procedimentos adotados nas sessões de criação}

Para tornar as sessões de criação produtivas, utilizamos a lista dos termos do MA (Apêndice C), revisada por duas especialistas. Os termos foram organizados em 12 categorias, conforme mencionamos no capítulo 3. Preparamos materiais visuais organizados em powerpoints, com imagens motivadoras da WEB e com os conceitos encontrados nas seis obras lexicográficas de que extraímos as definições do Meio Ambiente. Em geral, em cada sessão, procuramos trabalhar com conceitos conexos que pudessem ser utilizados como base para outros sinais de um mesmo campo semântico.

Como as sessões de criação ocorreram em grupos separados e, muitas vezes, os participantes tinham faltado reuniões anteriores, sempre era preciso atualizá-los dos sinais criados para mantê-los informados das bases usadas nos sinais. E neste momento, já ocorria uma avaliação não prevista dos sinais criados pelo outro grupo, o que ocasionou a criação de sinais variantes que foram apresentados nas sessões de validação para serem avaliados e escolhidos pelos participantes da escola.

Tivemos a preocupação com a compreensão efetiva do conceito antes da criação do sinal que, muitas vezes, em um primeiro momento, não atingiu o conceito desejado mas, durante o tempo da pesquisa, foram aperfeiçoados. Convém relembrar que a terminologia é parte da língua e, como a língua é viva, pode ocorrer várias mudanças na evolução natural das línguas, por razões políticas, por apreensão de novos conhecimentos, para evitar preconceitos e inadequações sociais. 
Além da preocupação com a estrutura linguística dos sinais-termo criados, é preciso atentar para uma questão posta por Robert Preis (1994, p.161), quando alerta para o uso de eufemismo nos termos do Meio Ambiente, porque os termos inadequados podem mascarar o real perigo das práticas humanas. O exemplo mencionado por ele foi o termo "defensivo agrícola", que mistifica o uso de venenos nos alimentos que consumimos. O mesmo serve à terminologia das línguas de sinais, para não expressar valores de teor duvidoso, que conduzam a práticas errôneas da população Surda frente às questões ambientais.

\subsection{Sessões de validação}

As sessões de validação foram reuniões com alunos surdos dos anos finais do Ensino Fundamental e com a professora regente para avaliar os sinais criados nas sessões de criação.

\subsubsection{Perfil dos participantes das sessões de validação}

Os participantes das sessões de validação foram os alunos surdos dos anos finais do Ensino Fundamental, $8^{\circ}$ e $9^{\circ}$ ano da EBT, Distrito Federal. Nesse caso, participaram 12 alunos, oito do $8^{\circ}$ ano e quatro do $9^{\circ}$ ano. As duas turmas, compostas apenas por surdos, eram bastante heterogêneas em relação à idade. A idade dos participantes variava de 13 a 28 anos. Outra característica da turma foi a idade em que aprenderam a LSB - a maioria aprendeu na infầncia. A idade de aquisição da LS dos alunos dessas turmas variava de 2 a 7 anos, porém, como exceção, um aluno aprendeu a LSB aos 15 anos. Logo nas primeiras visitas, constatamos que a maioria dos participantes dominava bem a LSB e se comunicava com naturalidade.

As sessões de validação foram realizadas tanto com alunos da escola de educação básica do $8^{\circ}$ e $9^{\circ}$ anos, quanto por surdos proficientes, com nível superior em Letras Libras. Isso porque os conteúdos relacionados à Genética não faziam parte do currículo regular dessas turmas.

O perfil dos colaboradores jovens e adultos que participaram das sessões de validação considerou que nenhum participou dos momentos de criação lexical ou não participou das sessões em que foram criados os sinais a serem validados por eles. 


\subsubsection{Procedimentos adotados nas sessões de validação}

Para as sessões de validação, organizamos os vídeos dos sinais criados em 12 pastas que correspondem aos 12 campos temáticos mencionados na metodologia. Fizemos desta forma para que os sinais-termo da mesma categoria fossem validados, preferencialmente, na mesma sessão, pois facilitava a dedução intuitiva dos sinais que foram criados a partir de uma mesma base lexical, como nos sinais-termo para ESPÉCIE, que gerou POPULAÇÃO, que gerou COMUNIDADE.

A professora regente participou de todo o processo e nos auxiliou com seus conhecimentos de especialista. Em algumas sessões, ela ministrava aula sobre o assunto e depois apresentávamos os sinais sobre o tema da aula. A professora também preparava materiais visuais, uma espécie de vocabulários com os termos do Meio Ambiente e suas respectivas ilustrações. Nas sessões, apresentávamos os vídeos dos sinais criados e os alunos da escola os avaliavam.

Em relação aos sinais apresentados, as maiores críticas e rejeições decorreram de expressões não manuais (ENM) exageradas ou incorretas que geraram, em alguns momentos, risos e em outros, desconforto aos participantes. Outra queixa foi a criação de sinais muito extensos.

A maioria dos sinais teve boa aceitação. Os sinais com algum problema puderam ser reestruturados nas sessões de criação após as sugestões recebidas nas sessões de validação. Isso ocorreu porque várias sessões de criação e de validação aconteceram concomitantemente, um dia da semana na escola e outro no LabLibras. Dessa forma, muitos sinais que não tinham sido aceitos puderam ser reestruturados e apresentados novamente nas sessões de validação, ou para os alunos da escola ou para os jovens e adultos surdos formados em Letras Libras. Em geral, os sinais que foram aceitos com ressalva sofreram apenas pequenas alterações nos movimentos ou CMs, mas a base lexical permaneceu na estrutura dos sinais.

Os sinais rejeitados foram: CAATINGA, CAATINGA VARIANTE, EMISSÃO, HORMÔNIO, MATÉRIA PRIMA, OCEANO ÍNDICO, OCEANO ATLÂNTICO e VERME 2. Estes sinais não foram aceitos porque os surdos consideraram como mal formados e sem identidade com os referentes.

Os sinais que tiveram uma boa aceitação foram os mais visuais, os que mantiveram a mesma base em termos relacionados e os que apresentavam sequências como os sinais 
relacionados à cadeia alimentar e os sinais para os estados da matéria: sólido, líquido e gasoso.

As sessões da escola foram enriquecedoras: a professora organizava seus conteúdos para tornar possível o uso dos termos que pretendíamos validar. Os alunos surdos, em sua maioria, foram bastante participativos e deram muitas contribuições para o desenvolvimento dos sinais. Alguns alunos criaram novas unidades terminológicas que foram validadas pelos surdos adultos e tornaram-se parte do glossário. Servem de exemplos, os sinais OSTRA e LINHA DO EQUADOR.

\subsection{Sinais-termo do glossário}

Nesta seção, apresentamos os sinais que compõem a entrada dos verbetes, as formas no plural e as variantes dos sinais-termo . O quadro, a seguir, indica os sinais que foram criados, os que já existiam na LSB e os emprestados da ASL. O número total de sinais do glossário soma 288, destes 223 foram criados, 62 já existiam na LSB e apenas três são empréstimos da ASL.

Quadro 15 - Quadro de controle dos sinais-termo

\begin{tabular}{|l|c|c|c|}
\hline \multicolumn{1}{|c|}{ sinal } & criado & existente & emprestado \\
\hline 1. abelha & & $\mathrm{x}$ & \\
\hline 2. adubo & $\mathrm{x}$ & & \\
\hline 3. adubo orgânico & $\mathrm{x}$ & & \\
\hline 4. agricultura & $\mathrm{x}$ & & \\
\hline 5. agrotóxico & $\mathrm{x}$ & & \\
\hline 6. água doce & $\mathrm{x}$ & & \\
\hline 7. água potável & $\mathrm{x}$ & & \\
\hline 8. água salgada & $\mathrm{x}$ & & \\
\hline 9. alevino & & $\mathrm{x}$ & \\
\hline 10. alga & $\mathrm{x}$ & $\mathrm{x}$ & \\
\hline 11. Amazônia & $\mathrm{x}$ & & \\
\hline 12. ambientalista & & & \\
\hline 13. ambiente & & & \\
\hline 14. Antártica & & & \\
\hline 15. aquecimento global & & & \\
\hline
\end{tabular}




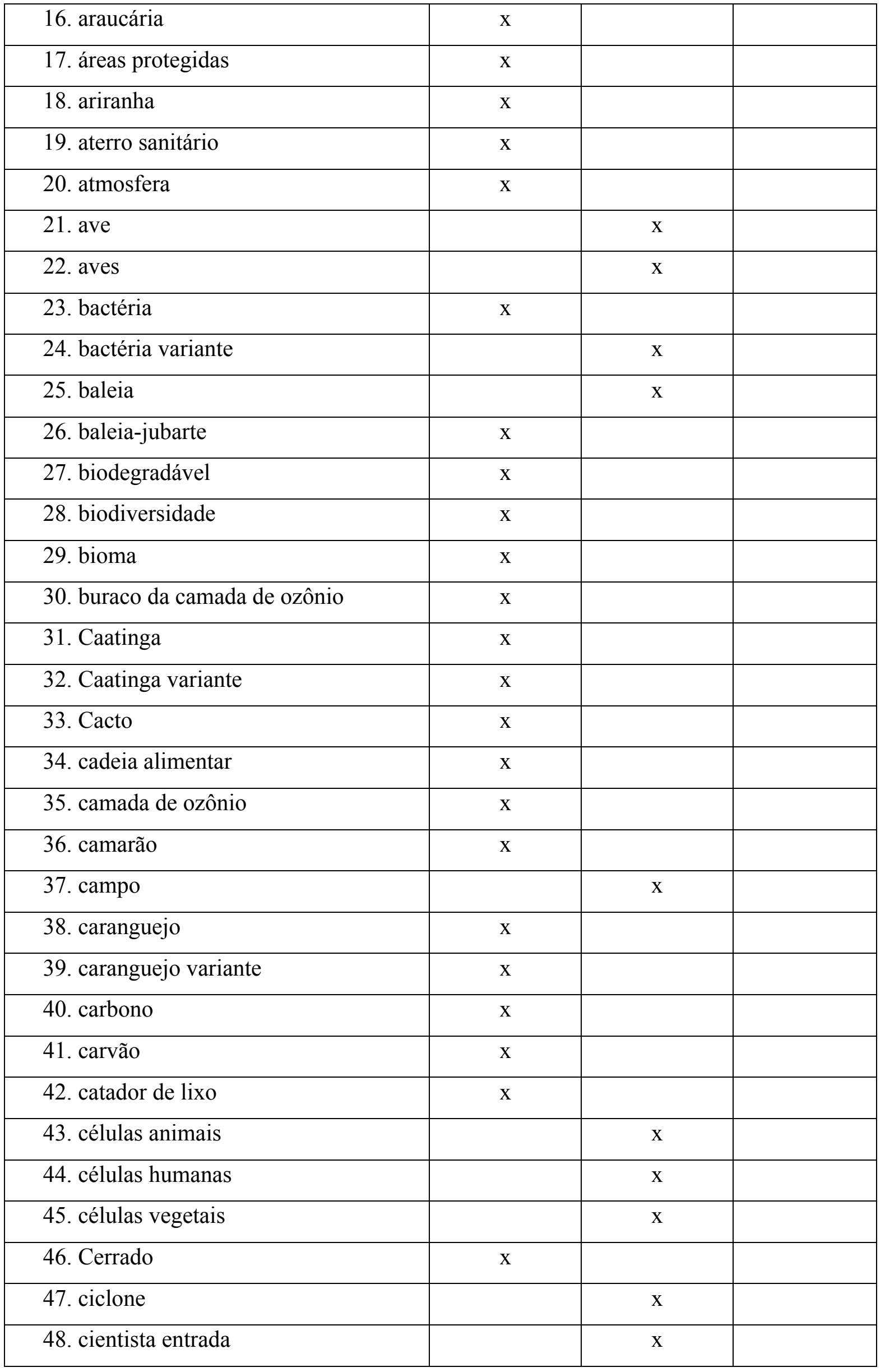




\begin{tabular}{|c|c|c|}
\hline 49. cientista variante & $\mathrm{x}$ & \\
\hline 50. clima & $\mathrm{x}$ & \\
\hline 51. clone animal & $\mathrm{x}$ & \\
\hline 52. clone humano & $\mathrm{x}$ & \\
\hline 53. clone vegetal & $\mathrm{x}$ & \\
\hline 54. $\mathrm{CO}_{2}$ & $\mathrm{x}$ & \\
\hline 55. coleta seletiva & $\mathrm{x}$ & \\
\hline 56. coletor de lixo & $\mathrm{x}$ & \\
\hline 57. colheita & $\mathrm{x}$ & \\
\hline 58. coluna vertebral & $\mathrm{x}$ & \\
\hline 59. combustível & & $\mathrm{x}$ \\
\hline 60. combustível fóssil & $\mathrm{x}$ & \\
\hline 61. comunidade & $\mathrm{x}$ & \\
\hline 62. Conferência das Partes & $\mathrm{x}$ & \\
\hline 63. conservação & & $\mathrm{x}$ \\
\hline 64. consumidor primário & $\mathrm{x}$ & \\
\hline 65. consumidor secundário & $\mathrm{x}$ & \\
\hline 66. consumidor terciário & $\mathrm{x}$ & \\
\hline 67. consumidor quaternário & $\mathrm{x}$ & \\
\hline 68. consumidor de $5^{\text {a }}$ ordem & $\mathrm{x}$ & \\
\hline 69. COP & $\mathrm{x}$ & \\
\hline 70. costa & $\mathrm{x}$ & \\
\hline 71. cromossomo & $\mathrm{x}$ & \\
\hline 72. cromossomos & $\mathrm{x}$ & \\
\hline 73. decomposição & $\mathrm{x}$ & \\
\hline 74. decompositor & $\mathrm{x}$ & \\
\hline 75. degelo & $\mathrm{x}$ & \\
\hline 76. degradação & $\mathrm{x}$ & \\
\hline 77. desenvolvimento sustentável & $\mathrm{x}$ & \\
\hline 78. deslizamento de terra & $\mathrm{x}$ & \\
\hline 79. desmatamento & $\mathrm{x}$ & \\
\hline 80. diamante & $\mathrm{x}$ & \\
\hline 81. dióxido de carbono & $\mathrm{x}$ & \\
\hline
\end{tabular}




\begin{tabular}{|c|c|c|c|}
\hline 82. DNA & $\mathrm{x}$ & & \\
\hline 83. ebulição & $\mathrm{x}$ & & \\
\hline 84. ecologia & $\mathrm{x}$ & & \\
\hline 85. ecologia agrária & $\mathrm{x}$ & & \\
\hline 86. ecologia animal & $\mathrm{x}$ & & \\
\hline 87. ecologia florestal & $\mathrm{x}$ & & \\
\hline 88. ecologia industrial & $\mathrm{x}$ & & \\
\hline 89. ecossistema & $\mathrm{x}$ & & \\
\hline 90. educação ambiental & $\mathrm{x}$ & & \\
\hline 91. efeito estufa & $\mathrm{x}$ & & \\
\hline 92. emissão & $\mathrm{x}$ & & \\
\hline 93. enchente & & $\mathrm{x}$ & \\
\hline 94. encosta & $\mathrm{x}$ & & \\
\hline 95. endêmico & $\mathrm{x}$ & & \\
\hline 96. energia & & $\mathrm{x}$ & \\
\hline 97. energia elétrica & & $\mathrm{x}$ & \\
\hline 98. erosão & & $\mathrm{x}$ & \\
\hline 99. esgoto & & $\mathrm{x}$ & \\
\hline 100.espécie & $\mathrm{x}$ & & \\
\hline 101. evaporação & $\mathrm{x}$ & & \\
\hline 102.extinção & $\mathrm{x}$ & & \\
\hline 103.extração & $\mathrm{x}$ & & \\
\hline 104. fauna & $\mathrm{x}$ & & \\
\hline 105. felino & $\mathrm{x}$ & & \\
\hline 106. felino variante & $\mathrm{x}$ & & \\
\hline 107. fertilizante & $\mathrm{x}$ & & \\
\hline 108. flora & $\mathrm{x}$ & & \\
\hline 109.floresta & & $\mathrm{x}$ & \\
\hline 110.floresta tropical & $\mathrm{x}$ & & \\
\hline 111.foca & & $\mathrm{x}$ & \\
\hline 112. foca variante & $\mathrm{x}$ & & \\
\hline 113. folha & & $\mathrm{x}$ & \\
\hline 114.fóssil & $\mathrm{x}$ & & \\
\hline
\end{tabular}




\begin{tabular}{|c|c|c|c|}
\hline 115.fossilização & $\mathrm{x}$ & & \\
\hline 116. furacão & & $\mathrm{x}$ & \\
\hline 117.gás & $\mathrm{x}$ & & \\
\hline 118.gás carbônico & $\mathrm{x}$ & & \\
\hline 119.gasoso & & & $\mathrm{x}$ \\
\hline 120.geada & $\mathrm{x}$ & & \\
\hline 121.geadas (plural em LSB) & $\mathrm{x}$ & & \\
\hline 122.gelo & $\mathrm{x}$ & & \\
\hline 123.gene & $\mathrm{x}$ & & \\
\hline 124.genes & $\mathrm{x}$ & & \\
\hline 125.genética & & $\mathrm{x}$ & \\
\hline 126. habitat & $\mathrm{x}$ & & \\
\hline 127.hidrogênio & $\mathrm{x}$ & & \\
\hline 128.hidrosfera & $\mathrm{x}$ & & \\
\hline 129. horta & & $\mathrm{x}$ & \\
\hline 130.hortaliças & $\mathrm{x}$ & & \\
\hline 131.iceberg & $\mathrm{x}$ & & \\
\hline 132.ilha & $\mathrm{x}$ & & \\
\hline 133.impacto ambiental & $\mathrm{x}$ & & \\
\hline 134.Índico & $\mathrm{x}$ & & \\
\hline 135.inundação & & $\mathrm{x}$ & \\
\hline 136.invertebrado & $\mathrm{x}$ & & \\
\hline 137.invertebrados & $\mathrm{x}$ & & \\
\hline 138.lago & & $\mathrm{x}$ & \\
\hline 139. lagosta & & $\mathrm{x}$ & \\
\hline 140. lagosta variante & $\mathrm{x}$ & & \\
\hline 141.lama & $\mathrm{x}$ & & \\
\hline 142.lavoura & $\mathrm{x}$ & & \\
\hline 143.lençol freático & $\mathrm{x}$ & & \\
\hline 144.leopardo & $\mathrm{x}$ & & \\
\hline 145.leopardo variante & $\mathrm{x}$ & & \\
\hline 146.linha do equador & $\mathrm{x}$ & & \\
\hline 147.líquido & & & $\mathrm{x}$ \\
\hline
\end{tabular}




\begin{tabular}{|c|c|c|}
\hline 148.litoral & $\mathrm{x}$ & \\
\hline 149.lixo & & $\mathrm{x}$ \\
\hline 150.1ula & & $\mathrm{x}$ \\
\hline 151.mamífero & $\mathrm{x}$ & \\
\hline 152.mar & & $\mathrm{x}$ \\
\hline 153.maré & $\mathrm{x}$ & \\
\hline 154.maré alta & $\mathrm{x}$ & \\
\hline 155.maré baixa & $\mathrm{x}$ & \\
\hline 156.mata & & $\mathrm{x}$ \\
\hline 157. Mata Atlântica & $\mathrm{x}$ & \\
\hline 158.matéria-prima & $\mathrm{x}$ & \\
\hline 159.meio ambiente & $\mathrm{x}$ & \\
\hline 160.melânico & $\mathrm{x}$ & \\
\hline 161.melânico variante & $\mathrm{x}$ & \\
\hline 162.melanismo & $\mathrm{x}$ & \\
\hline 163.melanismo variante & $\mathrm{x}$ & \\
\hline 164.metal & $\mathrm{x}$ & \\
\hline 165.meteorologia & $\mathrm{x}$ & \\
\hline 166. mico & & $\mathrm{x}$ \\
\hline 167.mico-leão & $\mathrm{x}$ & \\
\hline 168.mico-leão-dourado & $\mathrm{x}$ & \\
\hline 169.micro-organismo & $\mathrm{x}$ & \\
\hline 170.minério & $\mathrm{x}$ & \\
\hline 171.molécula & $\mathrm{x}$ & \\
\hline 172.moluscos & $\mathrm{x}$ & \\
\hline 173.montanha & & $\mathrm{x}$ \\
\hline 174.muda & $\mathrm{x}$ & \\
\hline 175.mudas & $\mathrm{x}$ & \\
\hline 176.mudas variante & $\mathrm{x}$ & \\
\hline 177.mudança climática & $\mathrm{x}$ & \\
\hline 178.mundo & & $\mathrm{x}$ \\
\hline 179.muriqui & $\mathrm{x}$ & \\
\hline 180.mutação & $\mathrm{x}$ & \\
\hline
\end{tabular}




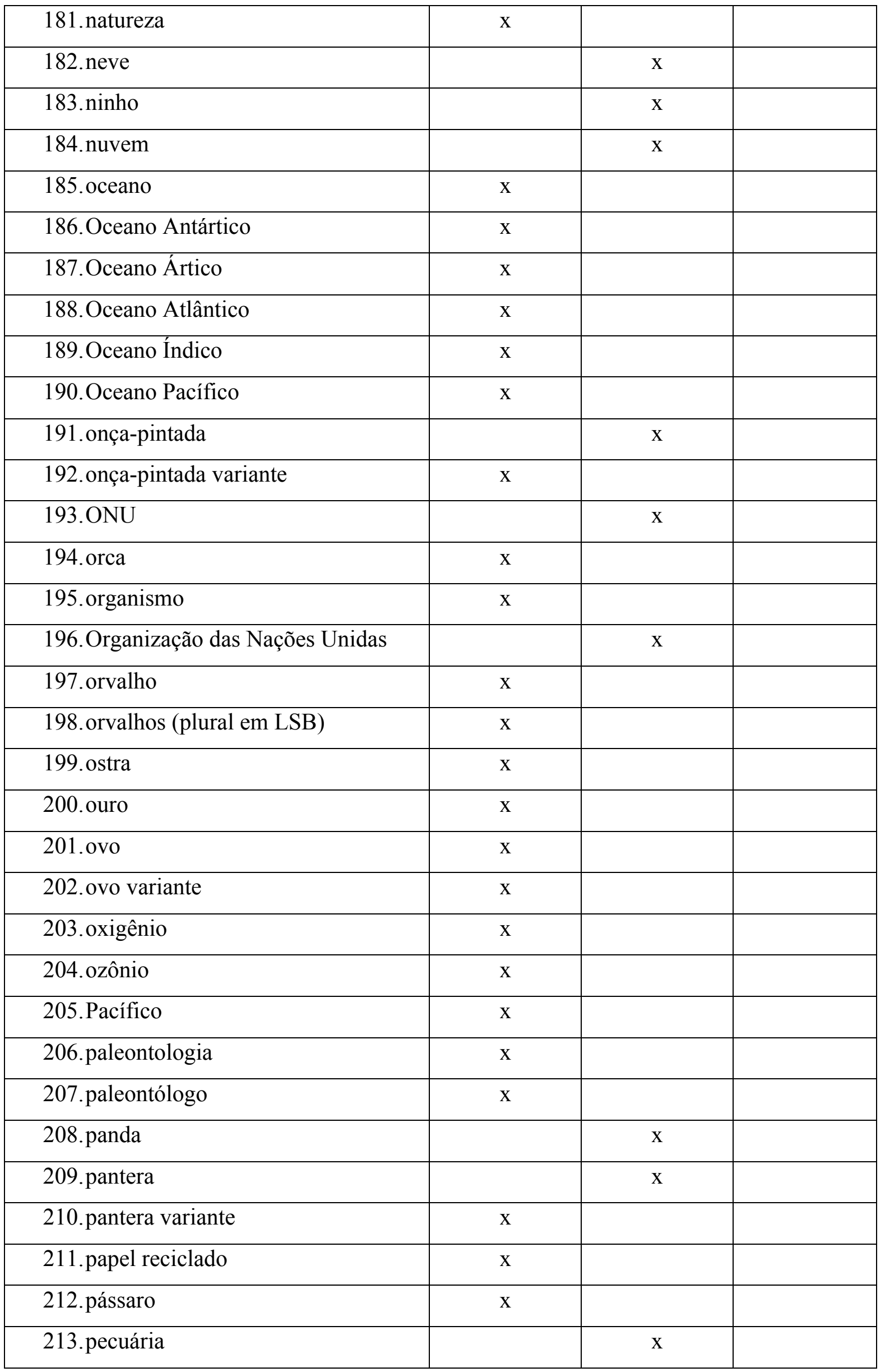




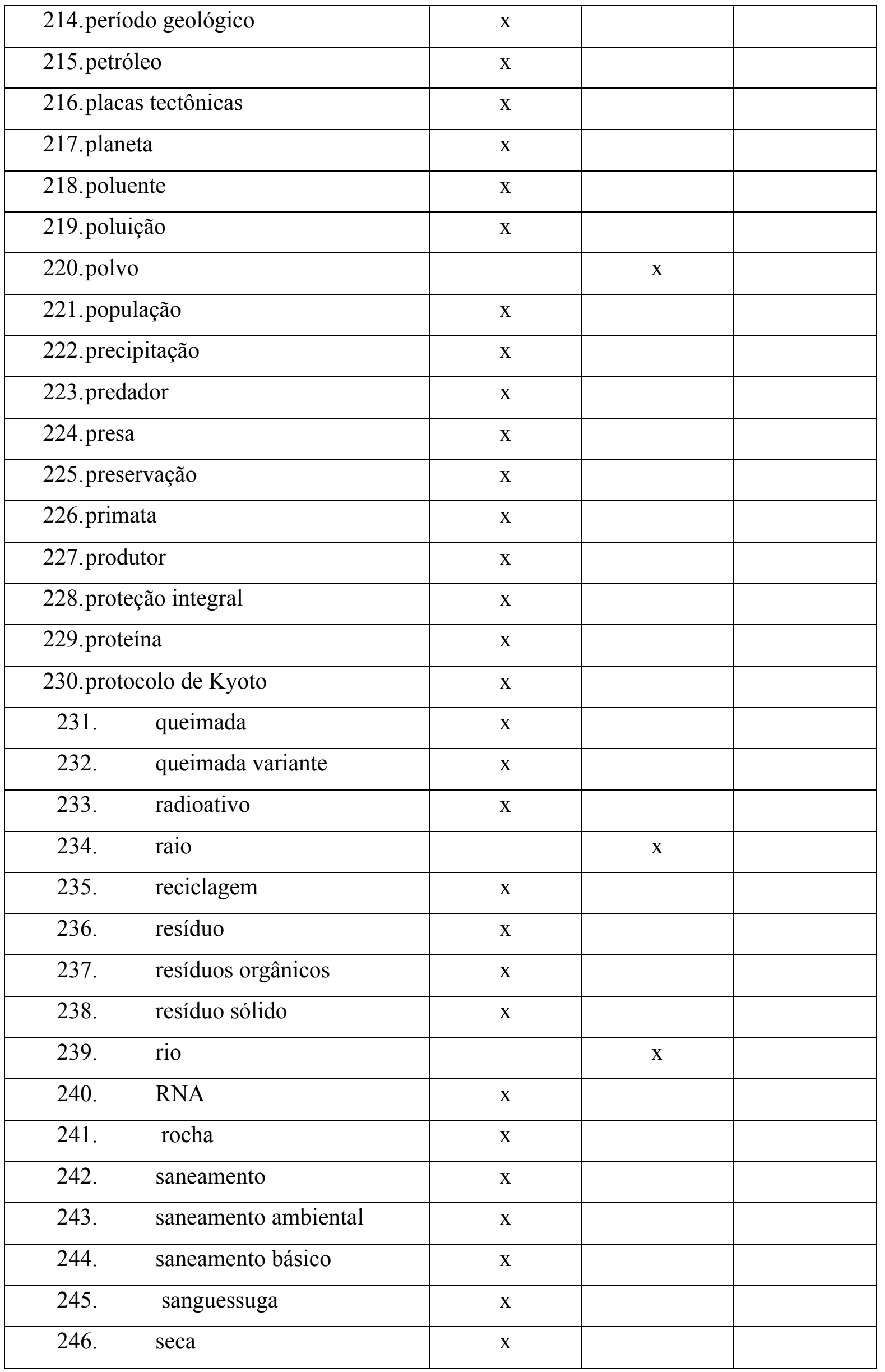




\begin{tabular}{|c|c|c|c|c|}
\hline 247. & seleção natural & $\mathrm{x}$ & & \\
\hline 248. & semente & $\mathrm{x}$ & & \\
\hline 249. & serra & & $\mathrm{x}$ & \\
\hline 250. & siri & & $\mathrm{x}$ & \\
\hline 251. & soja & $\mathrm{x}$ & & \\
\hline 252. & sólido & & & $\mathrm{x}$ \\
\hline 253. & solo & $\mathrm{x}$ & & \\
\hline 254. & solo variante & $\mathrm{x}$ & & \\
\hline 255. & suçuarana & & $\mathrm{x}$ & \\
\hline 256. & suçuarana variante & $\mathrm{x}$ & & \\
\hline 257. & sustentabilidade & $\mathrm{x}$ & & \\
\hline 258. & tabaco & $\mathrm{x}$ & & \\
\hline 259. & tabagismo & $\mathrm{x}$ & & \\
\hline 260. & tatu-bola & $\mathrm{x}$ & & \\
\hline 261. & temperatura & & $\mathrm{x}$ & \\
\hline 262. & tempestade & $\mathrm{x}$ & & \\
\hline 263. & termoelétrica & $\mathrm{x}$ & & \\
\hline 264. & Terra & & $\mathrm{x}$ & \\
\hline 265. & tigre & & $\mathrm{x}$ & \\
\hline 266. & tigre variante & $\mathrm{x}$ & & \\
\hline 267. & tornado & & $\mathrm{x}$ & \\
\hline 268. & tráfico de animais & $\mathrm{x}$ & & \\
\hline 269. & transgênico & $\mathrm{x}$ & & \\
\hline 270. & tratamento de água & $\mathrm{x}$ & & \\
\hline 271. & trigo & $\mathrm{x}$ & & \\
\hline 272. & trovão & & $\mathrm{x}$ & \\
\hline 273. & tubarão & & $\mathrm{x}$ & \\
\hline 274. & tubarão martelo & $\mathrm{x}$ & & \\
\hline 275. & tufão & & $\mathrm{x}$ & \\
\hline 276. & universo & & $\mathrm{x}$ & \\
\hline 277. & urbanização & $\mathrm{x}$ & & \\
\hline 278. & usina & $\mathrm{x}$ & & \\
\hline 279. & usina nuclear & $\mathrm{x}$ & & \\
\hline
\end{tabular}




\begin{tabular}{|cl|c|c|c|}
\hline 280. & vegetação & $\mathrm{x}$ & & \\
\hline 281. & vegetal & $\mathrm{x}$ & $\mathrm{x}$ & \\
\hline 282. & vento & $\mathrm{x}$ & & \\
\hline 283. & verduras & & $\mathrm{x}$ & \\
\hline 284. & verme & & $\mathrm{x}$ & \\
\hline 285. & verme variante & $\mathrm{x}$ & & \\
\hline 286. & vermes & $\mathrm{x}$ & & \\
\hline 287. & vertebrados & vírus & & \\
\hline 288. &
\end{tabular}

Fonte: Elaborado pela autora

A partir do quadro 15 é possível identificar 17 sinais-termo que têm forma variante em LSB, os sinais nesta condição são: CAATINGA, CARANGUEJO, CIENTISTA, FELINO, FOCA, LAGOSTA, LEOPARDO, MELÂNICO, MELANISMO, MUDAS, ONÇAPINTADA, OVO, PANTERA, QUEIMADA, SOLO, SUÇUARANA e VERME.

Também identificamos os sinais que possuem variantes em LP mas que em LSB o sinal permaneceu o mesmo. Os termos identificados nesta situação foram costa e litoral; Ambiente e Meio Ambiente; $\mathrm{CO}_{2}$, gás carbônico e dióxido de carbono; fertilizante e adubo; mata e floresta; furacão, tornado, tufão e ciclone; ONU e Organização das Nações Unidas e; COP e Conferência das Partes.

A seguir apresentamos a descrição de alguns mecanismos de criação dos sinais-termo do MA da LSB.

\subsection{Descrição dos mecanismos de criação dos sinais-termo do Meio Ambiente}

Uma análise preliminar dos processos criativos, identificados nas sessões de criação, bem como, alguns mecanismos já descritos por outros pesquisadores da LSB e de outras LS, apresentados no capítulo 1 deste estudo, são discutidos nesta seção.

Organizamos os sinais em grupos para evidenciar a relação entre os sinais motivados por uma mesma base. Sobre esta possibilidade de desenvolvimento terminológico, FariaNascimento (2009, p.112) mencionou que a expansão terminológica poderia partir do princípio de que os termos pertencentes ao mesmo campo semântico teriam a possibilidade de se expandir a partir de uma mesma base e Ramos Costa (2012, p. 45) afirma que a informação 
conceitual está na base. Apresentamos a seguir alguns grupos de sinais que demonstram a transparência do sistema da LSB para criação de novos sinais e a presença quase unânime de sinais motivados. A exceção é o sinal ESPÉCIE. Este sinal, apesar de ser o único arbitrário dos nossos dados, motivou dois outros sinais, que são POPULAÇÃO e COMUNIDADE. Para mostrar as relações existentes entre os sinais-termo do glossário, organizamos os dados em 27 grupos onde evidenciamos as relações semânticas dos sinais por meio da estrutura lexical.

O Grupo 1 é composto de sinais-termo relacionados à área da cultura e a base de criação está dentro do sinal HORTA, a mão passiva, como os dedos abertos no PA e OR mostrados na figura 33 representam os espaços onde são plantados os vegetais. Os sinais que identificamos pertencer a este grupo são: HORTA, HORTALIÇAS, VERDURAS, SEMENTE, AGROTÓXICO, ADUBO/FERTILIZANTE, ADUBO ORGÂNICO, COLHER, PROTEÇÃO INTEGRAL, LAVOURA, MUDA, MUDAS e AGRICULTURA (figura 34).

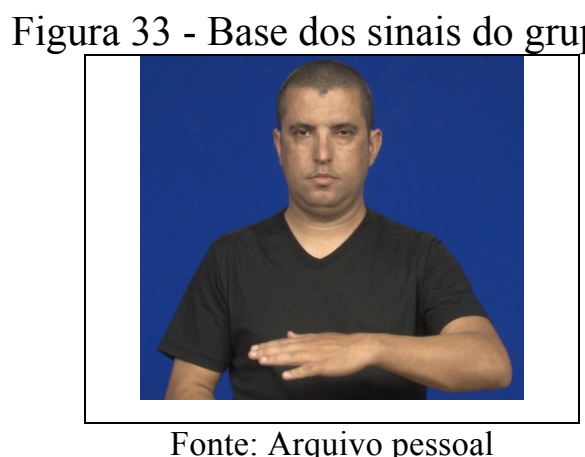

Fonte: Arquivo pessoal

Figura 34 - Sinais do grupo 1

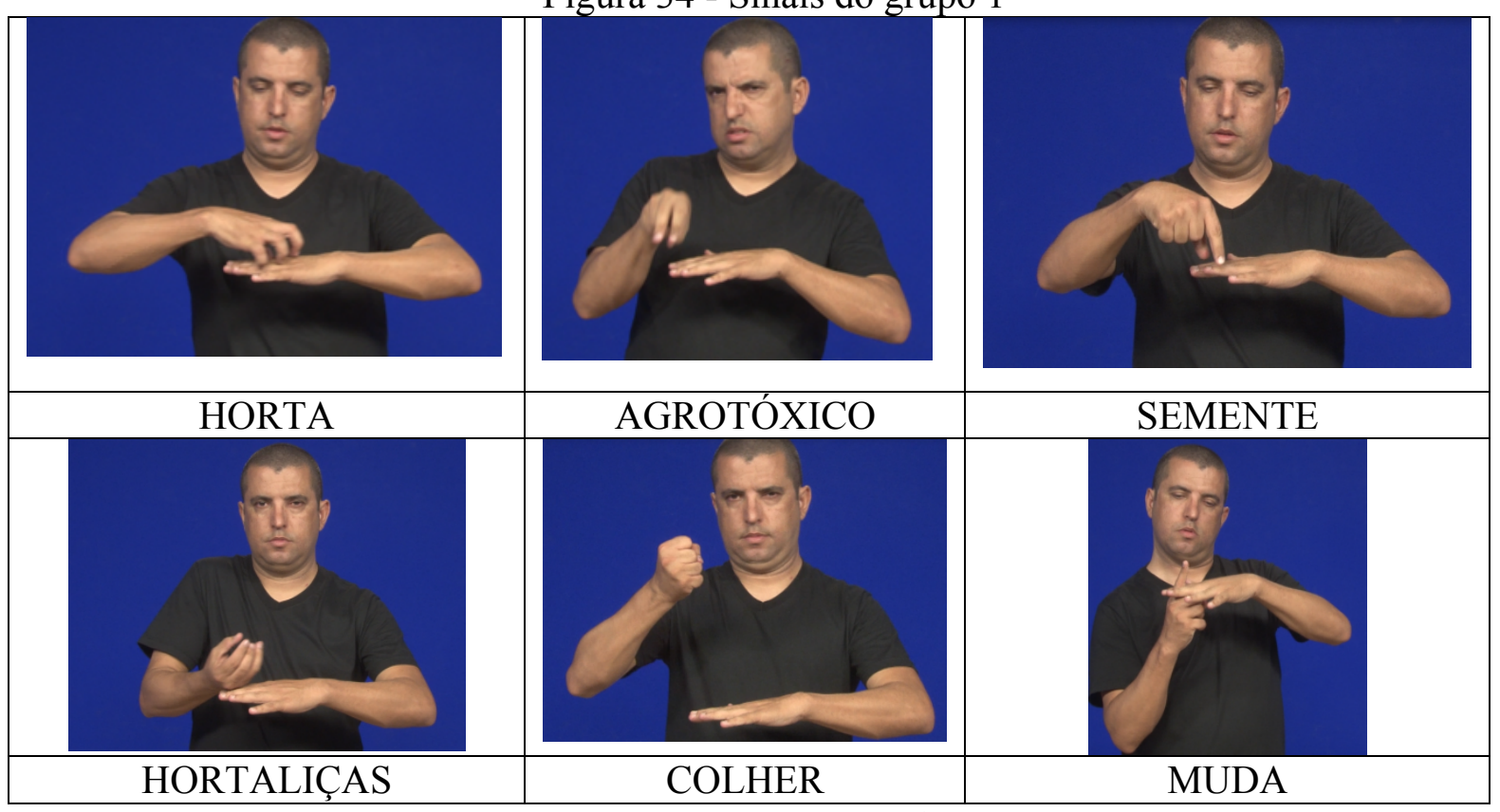

Fonte: Arquivo pessoal 
O sinal de LAVOURA, por exemplo, é bem semelhante ao de HORTA. Apenas a mão ativa faz o movimento do sinal PREPARAR, representando a terra pronta para a plantação. Em AGROTÓXICO, a mão ativa faz o sinal de VENENO em cima da base, mão não dominante, em comum desses sinais.

Os sinais do grupo 2 têm a mesma base, como apresentada na figura 35. Estão ligados a esta base os sinais: CADEIA ALIMENTAR, PRODUTOR, DECOMPOSITOR, CONSUMIDOR PRIMÁRIO, CONSUMIDOR SECUNDÁRIO, CONSUMIDOR TERCIÁRIO, CONSUMIDOR QUATERNÁRIO, CONSUMIDOR DE NÍVEL CINCO (figura 36). A partir desse mecanismo criativo da língua, é possível criar termos para todos os consumidores da cadeia alimentar, tantos quanto forem necessários.

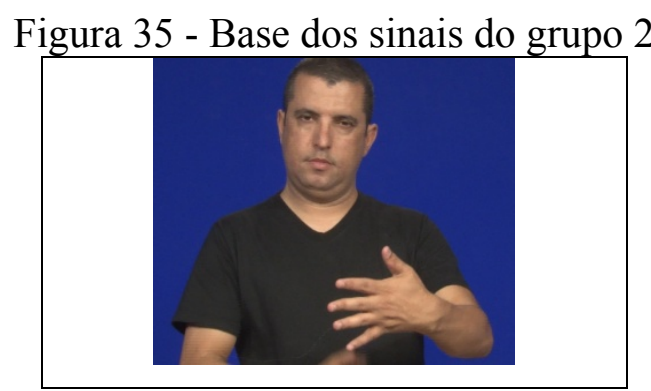

Fonte: Arquivo pessoal

Figura 36 - Sinais relacionados à cadeia alimentar

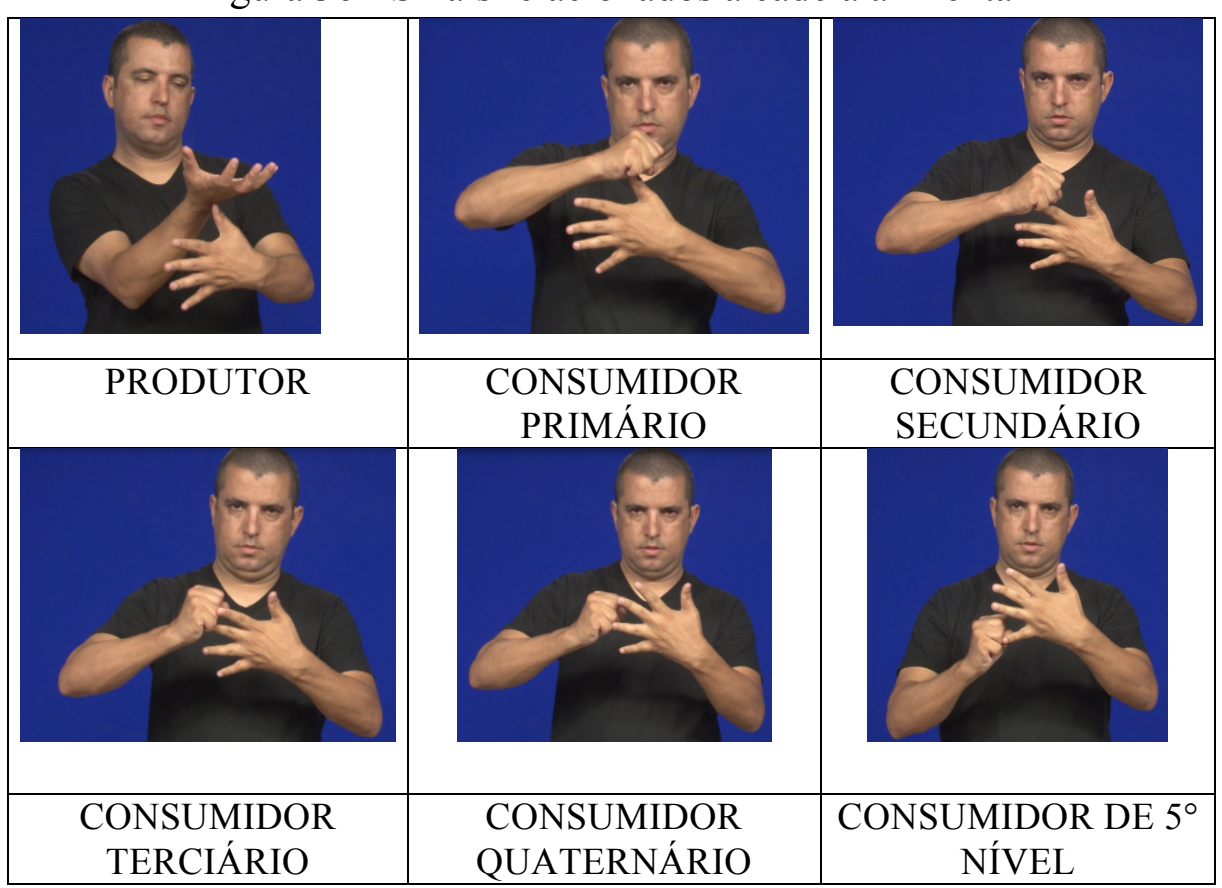

Fonte: Arquivo pessoal 
O sinal ENERGIA do grupo 3 motiva a CM e o movimento de parte dos sinais-termo TERMOELÉTRICA e ENERGIA ELÉTRICA, que recebem novos pontos de articulação e novos elementos. Neste último caso, há um acréscimo de uma segunda mão. Já em TERMOELÉTRICA, o sinal FÁBRICA é parte da composição deste termo em LSB.

Figura 37 - Sinal ENERGIA, que motivou parte dos sinais do grupo 3

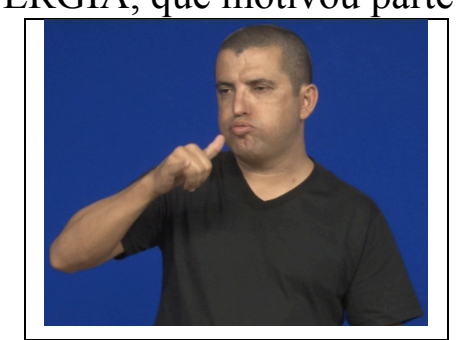

Fonte: Arquivo pessoal

Os sinais existentes AUMENTO-DA-TEMPERATURA e MUNDO do grupo 4, juntaram-se para formar o sinal composto AQUECIMENTO GLOBAL.

Figura 38 - Sinal AUMENTO-DA-TEMPERATURA

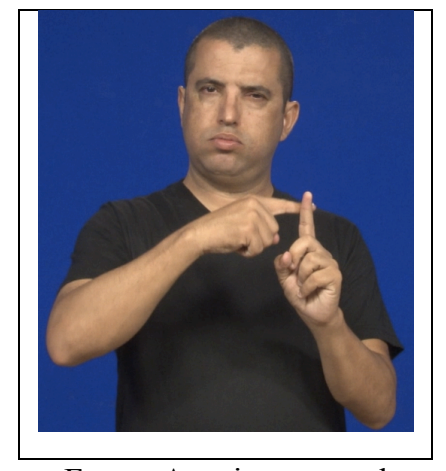

Fonte: Arquivo pessoal

O sinal BALEIA do grupo 5 motivou a criação de BALEIA-JUBARTE. A baleiajubarte é conhecida por fazer acrobacias no mar. Esta característica também influenciou a composição deste sinal que é constituído por BALEIA^ACROBACIA. A composição especificou o tipo de baleia. 
Figura 39 - Sinal BALEIA e BALEIA-JUBARTE

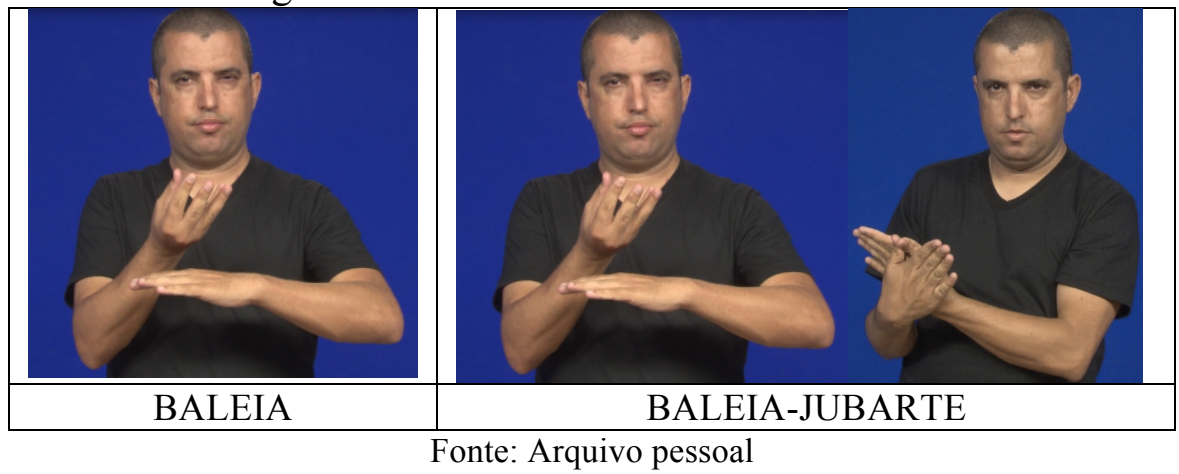

O sinal criado PROTOCOLO DE KYOTO, do grupo 6, tem o sinal DOCUMENTO, já existente na língua, como motivador de parte do sinal-termo, e o sinal é motivado também pelas $\mathrm{CM}$ das duas primeiras letras de Kyoto, $\mathrm{K}$ e $\mathrm{Y}$, e pelo movimento do sinal ASSINAR quando está com a CM em Y.

O sinal FÓSSIL do grupo 7 foi criado com base na referência de que, em geral, os fósseis são encontrados em camadas mais profundas da terra. Este sinal motivou a criação de FOSSILIZAÇÃO, PALEONTÓLOGO e PALEONTOLOGIA. O sinal COMBUSTÍVEL FOSSIL foi motivado pela localização de FÓSSIL, pelo sinal EXTRAIR e pelo sinal de COMBUSTÍVEL, este último já existente na língua.

Figura 40 - Sinal FÓSSIL

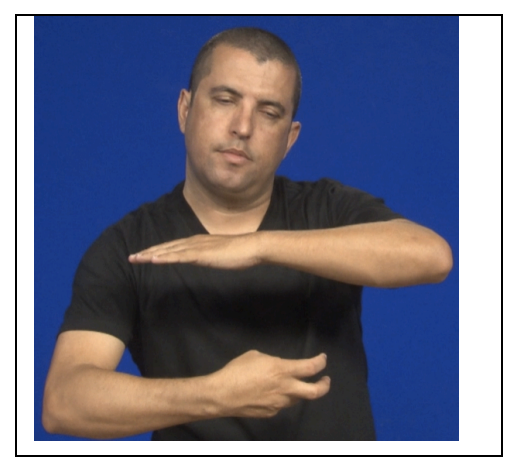

Fonte: Arquivo pessoal

Os sinais CONSERVAÇÃO, PRESERVAÇÃO, ÁREAS PROTEGIDAS e PROTEÇÃO INTEGRAL do grupo 8 têm em comum a base do sinal existente PROTEÇÃO. 
Figura 41 - Sinal PROTEÇÃO, base dos sinais do grupo 8

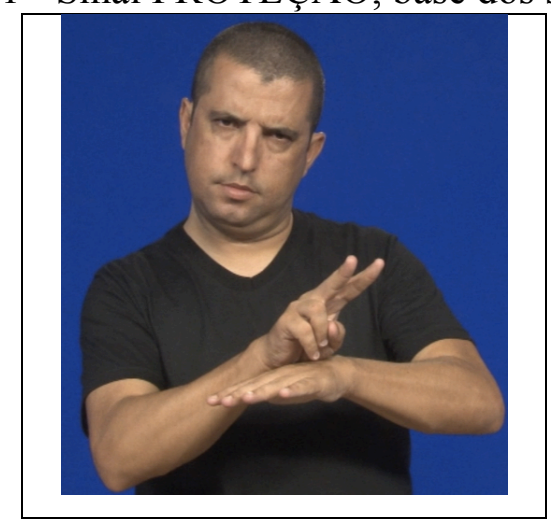

Fonte: Arquivo pessoal

O sinal GÁS do grupo 9 é a base de OZÔNIO. Este sinal já possuía uma forma existente que foi motivada por sua fórmula química. Esta fórmula motivou os sinais CAMADA DE OZÔNIO e BURACO DA CAMADA DE OZÔNIO.

Os sinais do grupo 10 têm em comum o sinal PODRE (figura 42) utilizado nos sinais LIXO, CATADOR DE LIXO, COLETA SELETIVA, ESGOTO e ATERRO SANITÁRIO.

Figura 42 - Sinal PODRE, base dos sinais do grupo 10

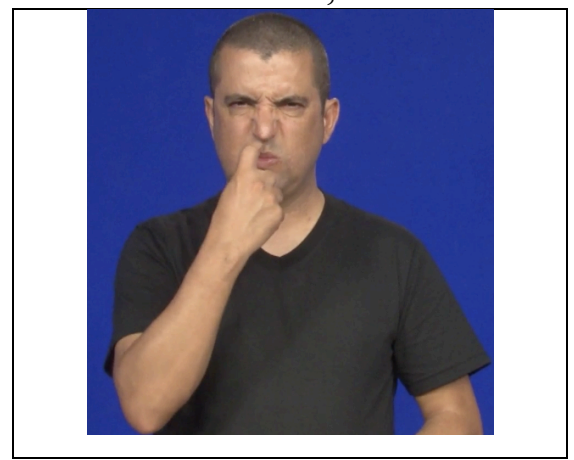

Fonte: Arquivo pessoal

Os sinais do grupo 11 têm em comum a base de criação mostrada na figura 43, que representa o mundo, CL para algo redondo, e pode ser identificada nos sinais MEIO AMBIENTE, LINHA DO EQUADOR, OCEANO ÍNDICO, e nos demais sinais-termo criados para dar nome aos oceanos. Ainda nesta mesma base podemos mencionar o sinal AMBIENTALISTA, POLUENTE e POLUIÇÃO. Além do mais, essa mesma base aparece no sinal SUSTENTABILIDADE, criado nesta pesquisa, que motivou a criação dos sinais DESENVOLVIMENTO SUSTENTÁVEL e EDUCAÇÃO AMBIENTAL. Estes dois sinais fizeram uso de sinais já existentes na língua que são, respectivamente, DESENVOLVIMENTO e EDUCAÇÃO 'ensino'. 
Figura 43 - Configuração de mão base dos sinais do grupo 11

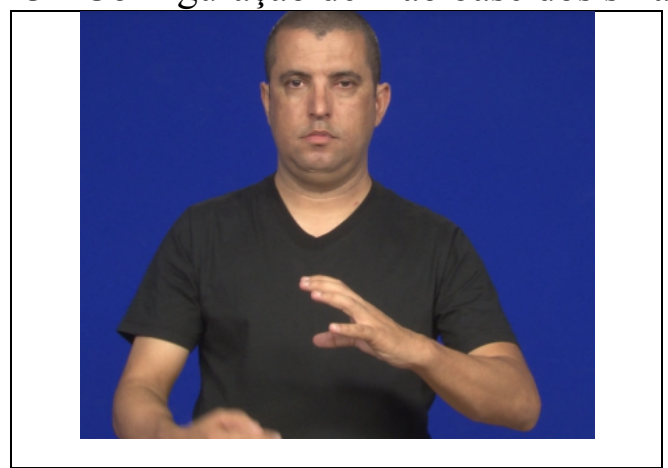

Fonte: Arquivo pessoal

Figura 44 - Sinais do grupo 11

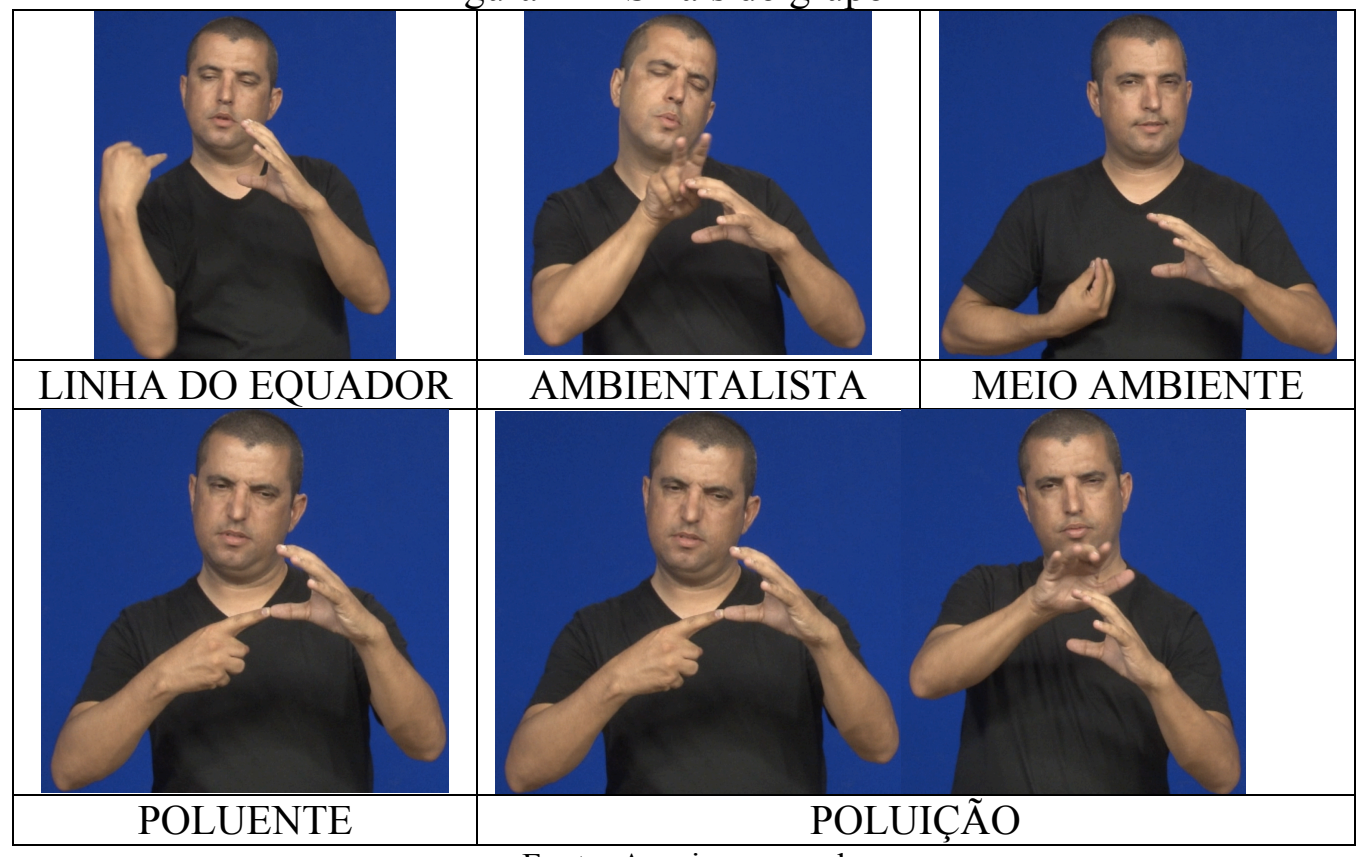

Fonte: Arquivo pessoal

O sinal criado COLUNA VERTEBRAL (figura 45), grupo 12, motivou a criação dos sinais VERTEBRADOS e INVERTEBRADOS.

Figura 45 - Sinal COLUNA VERTEBRAL

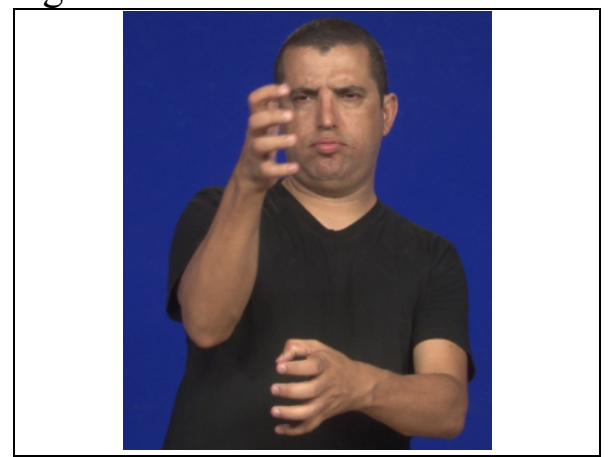

Fonte: Arquivo pessoal 
O sinal criado ESPÉCIE, grupo 13, é a base para o sinal POPULAÇÃO, que é base para COMUNIDADE.

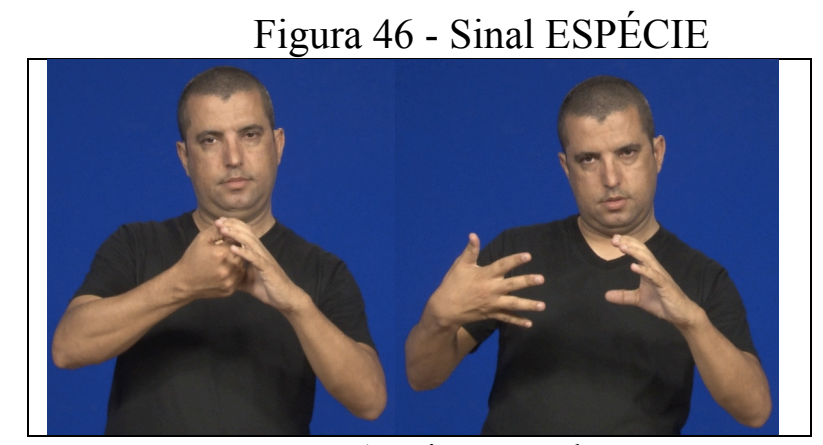

Fonte: Arquivo pessoal

Figura 47 - Sinal POPULAÇÃO

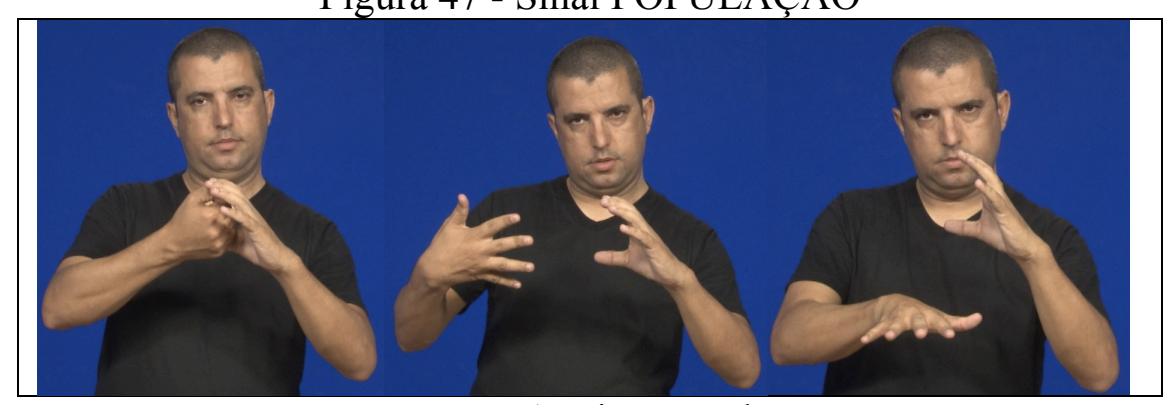

Fonte: Arquivo pessoal

Figura 48 - Sinal COMUNIDADE

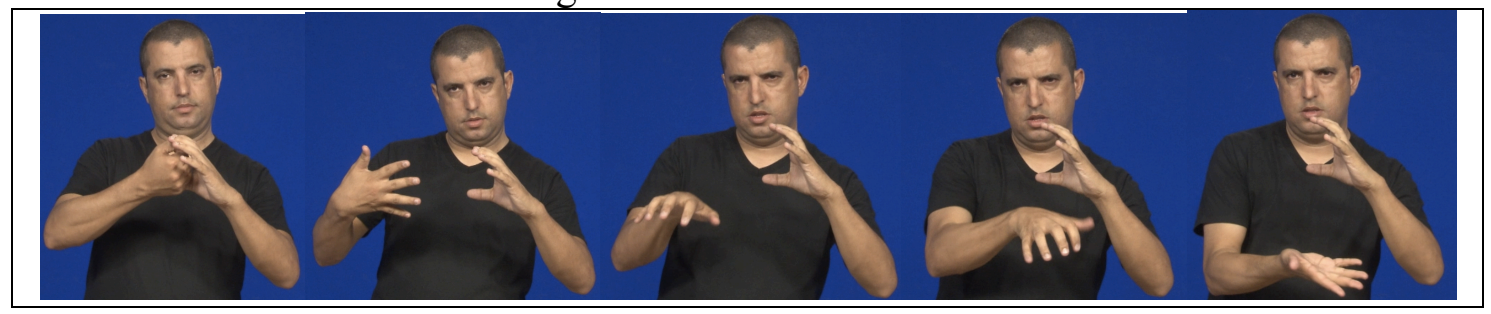

Fonte: Arquivo pessoal

O sinal ECOSSISTEMA do grupo 14 é base para BIOMA. A diferença entre eles é apenas o formato da mão passiva que, em BIOMA, por ser um conjunto de ecossistemas, possui uma CM que representa algo com grande dimensão, como mostra a figura 49. Esses sinais também são motivos pelos sinais existentes PEIXE e ÁRVORE. 
Figura 49 - Sinais ECOSSISTEMA e BIOMA

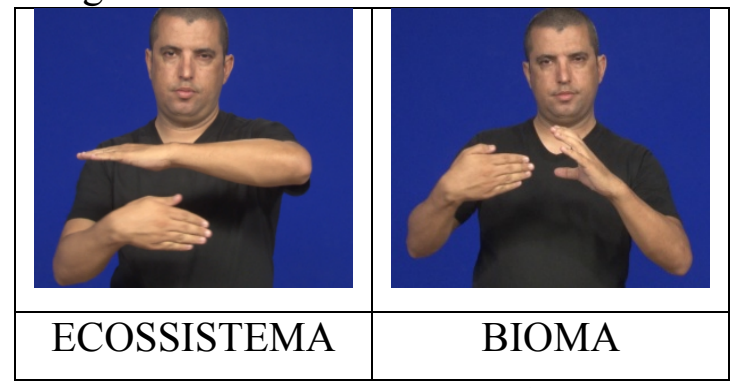

Fonte: Arquivo pessoal

Os sinais ATMOSFERA, CHUVA, SOL e ESTUDAR do grupo 15 motivaram a criação do sinal METEOROLOGIA. Outros sinais em que a base ESTUDAR está presente são: ECOLOGIA, PALEONTOLOGIA

Os sinais do grupo 16 têm ao sinal MACACO (figura 50) como base para criação dos sinais MICO, MICO-LEÃO, MICO-LEÃO-DOURADO, MURIQUI e PRIMATAS.

Figura 50 - Sinal MACACO, base dos sinais do grupo 16

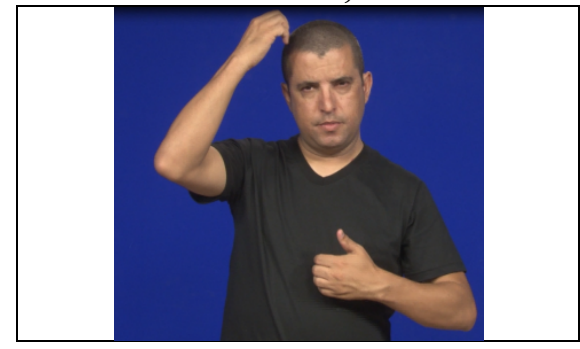

Fonte: Arquivo pessoal

O sinal GENÉTICA, do grupo 17, motivou a criação dos sinais: TRANSGÊNICO, MUTAÇÃO, CLONE HUMANO, CLONE ANIMAL e CLONE VEGETAL. Já os sinais DNA, GENE, GENES e RNA têm em sua estrutura influencia tanto do sinal GENÉTICA quanto do sinal CROMOSSOMO. O sinal PROTEÍNA é motivado pelos sinais CROMOSSOMO e RNA.

Figura 51 - Sinal GENÉTICA e CROMOSSOMO

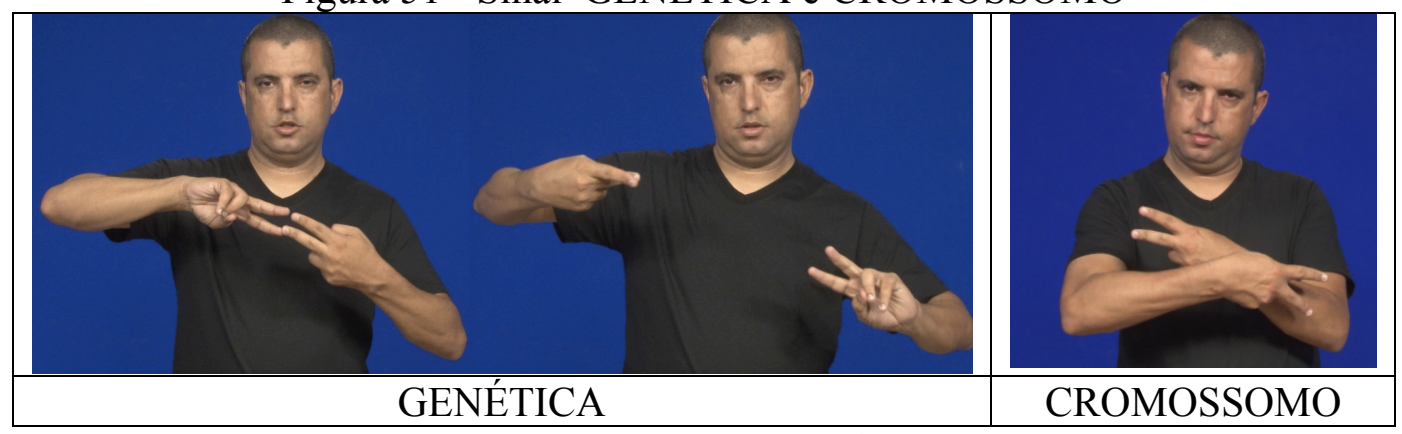

Fonte: Arquivo pessoal 
Os sinais RESÍDUO, RESÍDUO SÓLIDO e RESÍDUO ORGÂNICO, do grupo 18, têm como base o sinal DEIXAR, no sentido de largar algo.

Os sinais PANTERA, TIGRE, LEOPARDO, ONÇA-PINTADA e SUÇUARANA do grupo 19, todos têm em sua constituição o sinal LEÃO, ou o sinal BIGODES (figura 52), e mais alguma especificação do animal como a cor, listras ou formato das manchas.

Figura 52 - Sinais BIGODES e LEÃO

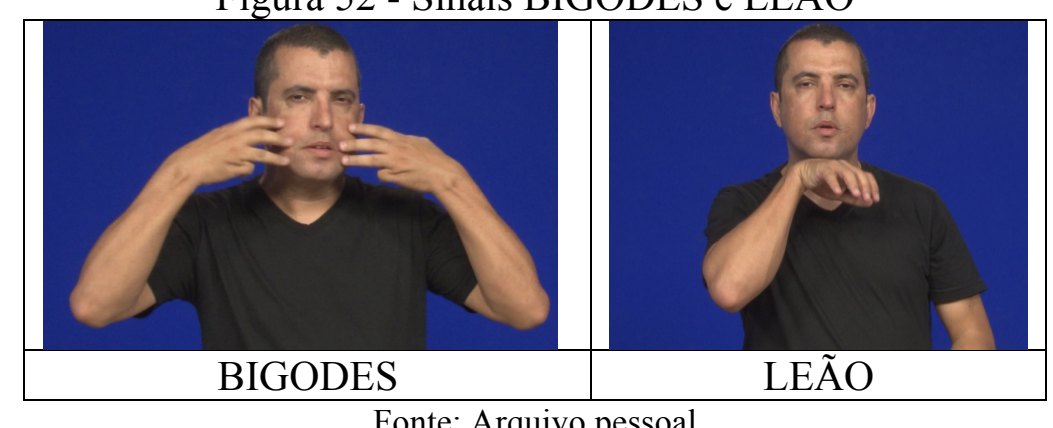

Fonte: Arquivo pessoal

Os sinais do grupo 20, TABAGISMO e TABACO, têm sua base no sinal CIGARRO (figura 53). O primeiro termo pode ser transcrito como CIGARRO^VÍCIO. Já o sinal TABACO, também composto por justaposição e pode ser transcrito por FOLHA^CIGARRO.

Figura 53 - Sinal CIGARRO, base dos sinais do grupo 20

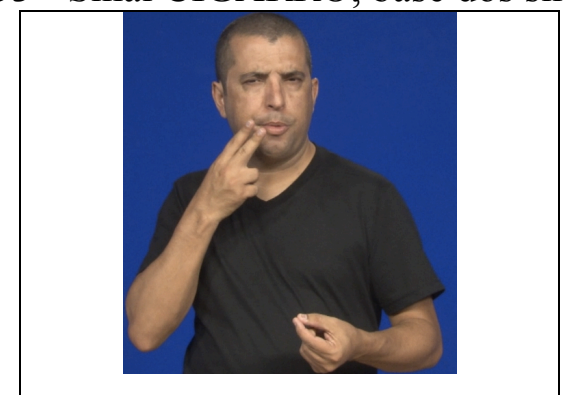

Fonte: Arquivo pessoal

Os sinais do grupo 21 têm uma parte motivada por FÁBRICA como USINA, USINA NUCLEAR e TERMELÉTRICA.

Figura 54 - Sinal FÁBRICA, base dos sinais do grupo 21

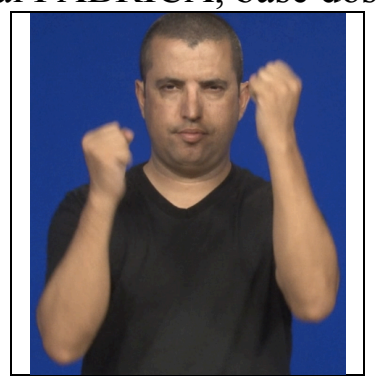

Fonte: Arquivo pessoal 
O sinal criado NATUREZA, grupo 22, tem como base o sinal SURGIR, sinal já existente, juntamente com a ENM de PAZ. Este sinal criado motivou os sinais BIODIVERSIDADE, ECOLOGIA, ECOLOGIA AGRÁRIA, ECOLOGIA ANIMAL, ECOLOGIA FLORESTAL e ECOLOGIA INDUSTRIAL.

O sinal MAR do grupo 23 motivou os sinais MARÉ BAIXA e MARÉ ALTA (figura 55) que, unidos na sequência mencionada, formam o sinal MARÉ. A transcrição deste sinal pode ser representada por MARÉ-BAIXA^MARÉ-ALTA. Além disso, o sinal MAR com o sinal CASA motivaram a criação do sinal INUNDAÇÃO. O movimento e a CM do sinal MAR também motivou o sinal COSTA/LITORAL que, por sua vez, compôs juntamente com o sinal MATA/FLORESTA o sinal-termo MATA ATLÂNTICA.

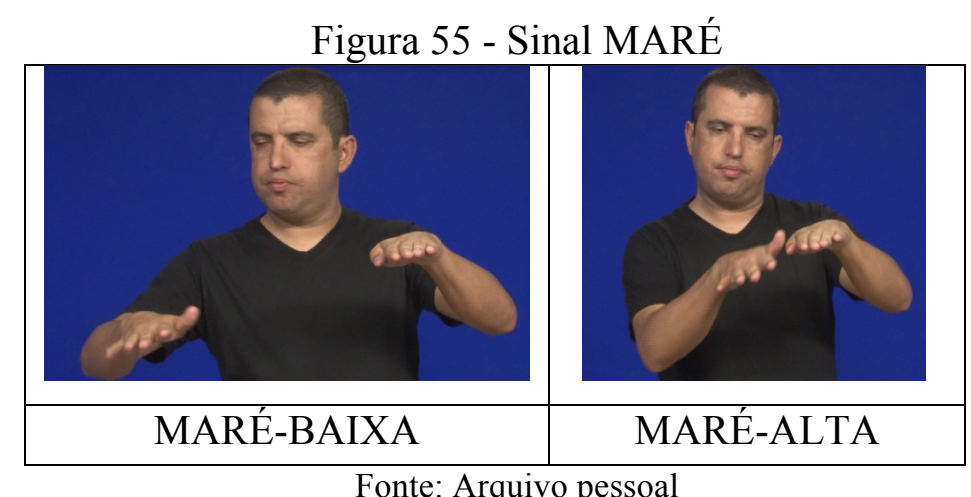

Os sinais do grupo 24, SÓLIDO, LÍQUIDO e GASOSO, emprestados da ASL, são sequências e motivaram o sinal EVAPORAÇÃO, como mostra a figura 56 a seguir.

Figura 56 - Sinais do grupo 24

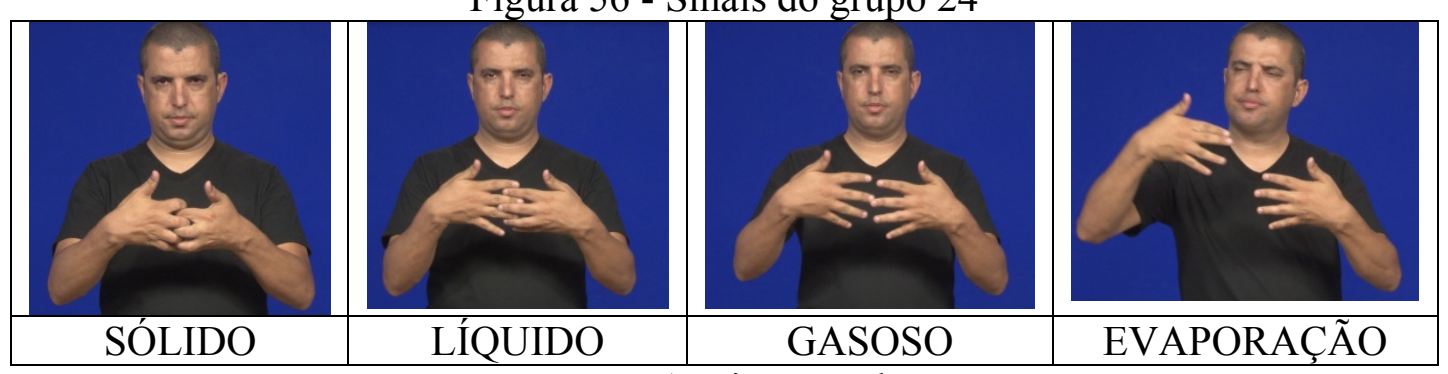

Fonte: Arquivo pessoal

O sinal RECICLAGEM (figura 57), grupo 25, foi criado com base no logotipo mundial deste conceito serviu de base para criação do sinal PAPEL RECICLADO (figura 58). 
Figura 57 - Sinal RECICLAGEM

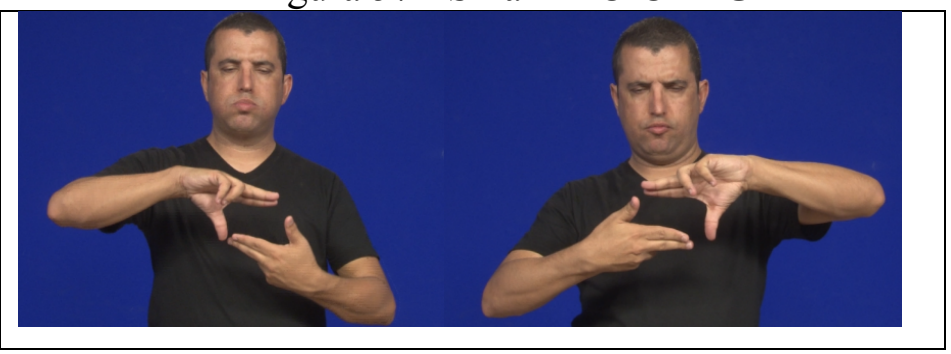

Fonte: Arquivo pessoal

Figura 58 - Sinal PAPEL RECICLADO

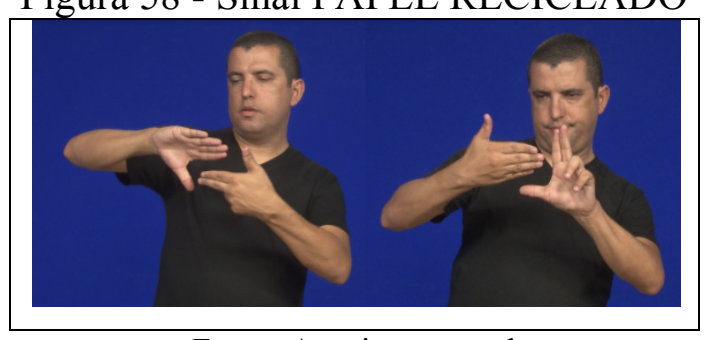

Fonte: Arquivo pessoal

O sinal GÁS, do grupo 26, criado nesta pesquisa, foi adicionado aos sinais existentes de OXIGÊNIO $\left(\mathrm{O}_{2}\right)$, OZÔNIO $\left(\mathrm{O}_{3}\right)$, e GÁS CARBÔNICO $\left(\mathrm{CO}_{2}\right)$ e os tornou compostos. O sinal de HIDROGÊNIO também foi criado com base no sinal GÁS que pode ser transcrito como GÁS ${ }^{\wedge} \mathrm{H}$.

Partes dos sinais MUNDO e FRIO, do grupo 27 motivaram a criação do sinal ANTÁRTICA e OCEANO ANTÁRTICO. O sinal FRIO também pode ser encontrado no sinal criado para GELO, que motivou DEGELO.

Podemos observar nos dados que os sinalizantes da LSB se apropriaram dos mecanismos linguísticos existentes nesta língua para criar novas unidades terminológicas. Estas estruturas dão transparência ao sistema que, muitas vezes, facilitam a dedução dos termos a partir de sua estrutura. Delbeque (2006, p. 33) já havia mencionado esta característica das línguas. Ela explicou que as novas palavras se constroem, geralmente, por meio de formas linguísticas já existentes e, por esse motivo, elas tornam-se significativas aos nossos olhos.

Existem muitas outras relações entre os sinais criados que podem ser evidenciadas pelos dados colhidos, bem como muitas análises sobre a inovação lexical, que podem ser extraídas do mesmo corpus.

A transparência é apenas um dos princípios para formação de termos, conforme a ISO 704:2000 (p. 25-27), documento internacional de normalização do trabalho terminológico. Na criação dos sinais-termo procuramos seguir os demais princípios da ISO 704, que são: 
coerência, adequação, economia linguística, derivabilidade, correção linguística e preferência pela língua nativa. Apresentamos, a seguir, exemplos no nosso trabalho de cada um desses princípios.

A coerência na terminologia dos sinais ambientais pode ser exemplificada por sinais que foram criados para se estabelecer a coerência do sistema conceitual, como por exemplo, os termos espécie, população, comunidade e ecossistema, que são conceitos interligados. Em nossa lista de 168 termos retirados do Jornal Folha de São Paulo, o termo comunidade não constava, todavia para se estabelecer um sistema terminológico coerente foi preciso criar um sinal-termo para o conceito comunidade.

Adequação pode ser notada nos sinais-termo pelo esforço de se evitar sinais que pudessem suscitar alguma conotação negativa ou preconceito, serve de exemplo TRANSGÊNICO, que apesar das inúmeras discussões sobre se há ou não consequências negativas do seu uso, recebeu um sinal que manteve a neutralidade do conceito.

Quanto à economia linguística, os próprios sinalizantes da LSB contribuíram com este princípio, ao se sentirem desconfortáveis com o tamanho dos termos. Todavia, em alguns momentos, foi preferível sinais mais longos como METEOROLOGIA para maior exatidão semântica em detrimento da economia linguística, situação essa mencionada na ISO 704, que diz que a exigência de concisão muitas vezes entra em conflito com a exatidão. É válido ressaltar, que alguns dos sinais-termo criados precisam ser usados pelos falantes para se acomodar a estrutura da LSB e isto pode contribuir com a economia linguística, já que o sistema dá preferência a itens lexicais menores.

A derivabilidade pode ser observada em um sinal como CADEIA ALIMENTAR, que tem mais sete sinais na mesma base, podendo ainda ser expandido o número de sinais associados a esta mesma base.

A correção linguística é evidenciada na estrutura dos sinais-termo que, em sua maioria, estão em conformidade com as regras morfológicas e fonológicas da LSB. As sessões de validação, além de avaliar o conteúdo semântico dos sinais, também tiveram como objetivo que os sinalizantes da LSB, como primeira língua, identificassem possíveis problemas na estrutura linguística dos sinais.

A preferência pela língua nativa foi um princípio que também observamos na criação dos sinais-termo, poucos foram os sinais motivados pela LP, como vemos na subseção 4.6.8, que trata dos sinais emprestados da LP à LSB. Além disso, como apresentamos na seção 4.2, onde registramos a pesquisa de busca de sinais do Meio Ambiente em materiais diversos, os sinais que eram emprestados da LP por meio do alfabeto manual da LSB, servem de exemplo, 
I-L-H-A, S-O-J-A e G-Á-S, foram substituídos por sinais criados dentro da estrutura lexical da LSB.

A seguir, apresentamos algumas análises relacionadas aos mecanismos de criação identificados nos sinais-termo do Meio Ambiente da LSB, com base em estudos realizados na LSB e de outras línguas de sinais.

\subsubsection{As marcas de plural em LSB}

Identificamos em nossos dados sete pares de sinais que apresentaram as formas no singular e no plural. Os pares dos sinais encontrados foram os seguintes: AVE/AVES, CROMOSSOMO/CROMOSSOMOS, GENE/GENES, INVERTEBRADO/INVERTEBRADOS，MUDA/MUDAS，ORVALHO/ORVALHOS， e VERME/VERMES.

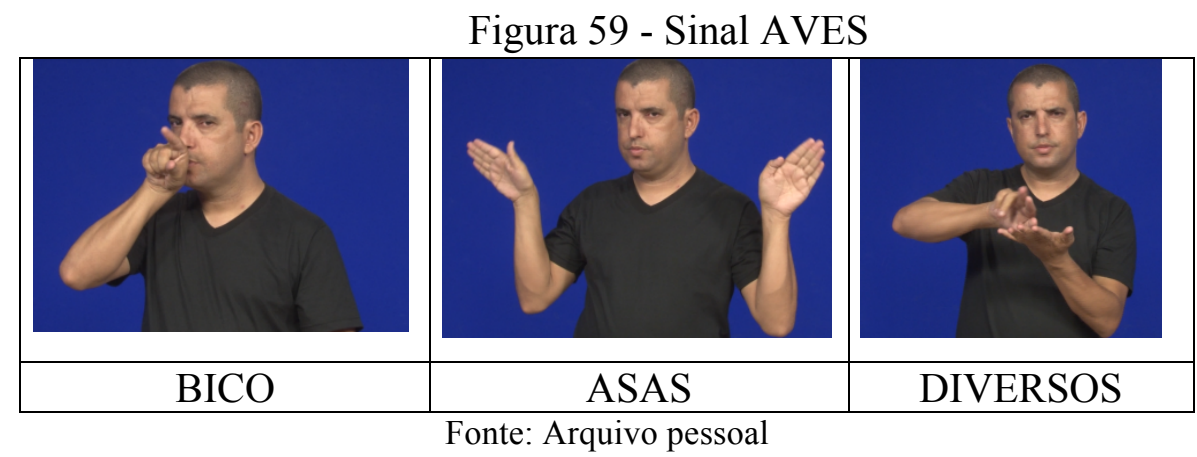

Os pares AVE/AVES e INVERTEBRADO/INVERTEBRADOS têm como marca de plural o que vem sendo convencionado nas glosas de DIVERSOS (figura 59).

O plural do sinal CROMOSSOMOS é marcado pelo movimento para frente e uma ENM que consiste em um sopro até a finalização do movimento. No par GENE/GENES, o plural é marcado pela repetição do movimento com deslocamento. Já em MUDA/MUDAS é a mudança na CM que marca o plural com a abertura de mais dedos na mão ativa na forma plural. Em VERME/VERMES, é o acréscimo de uma segunda mão que marca o número.

Sobre as diversas formas de marcar o plural, Costelo (1994, p. xv) já havia advertido nos seus estudos sobre a ASL. Contudo, a LSB também apresentou diferentes marcações de plural. A reduplicação foi uma das marcas de plural mencionas por Costelo e que identificamos no sinal GENES. Neste mesmo sinal, há uma outra característica que é o deslocamento durante o movimento repetido e nos remete a outra marca de plural, 
mencionado por Costelo como apontação para vários locais. Além disso, sabemos que o plural pode ter realização apenas sintática.

A partir da análise dos nossos dados, não identificamos nas ENM a responsabilidade única da marcação da forma plural, porém, foram essenciais como parte constitutiva da marca de plural.

\subsubsection{As expressões não manuais nos sinais-termo do Meio Ambiente}

As ENM são componentes fundamentais nas LS e podem diferenciar itens lexicais na LSB. Todavia, é preciso investigar um pouco mais para ter certeza se esse parâmetro diferencia termos. Isso porque ao observar os dados, identificamos o par de sinais AVE e PÁSSARO que se diferencia pelas ENM. O sinal AVE ocupa mais espaço na sinalização, enquanto que em PÁSSARO, o uso do espaço é mais restrito. Este sinal, assim como em muitos outros que expressam o diminutivo em LSB, são marcados pelo encolher do corpo e a expressão facial caracterizada por um bico formado pelos lábios como marca de algo de pequeno porte. Essas mesmas ENM também são encontradas no sinal de MICO que se refere a macaco pequeno. Dessa forma, observamos que essas ENM são gramaticais e marcam o grau de tamanho como explicitado em Quadros, Pizzio e Rezende (2008), o que parece não configurar a criação de um novo termo apenas marca o diminutivo.

Os sinais ESGOTO, LIXO, ATERRO SANITÁRIO e COLETIVA SELETIVA possuem uma ENM atrelada ao sinal base PODRE. Esta ENM não é gramatical e parece ter o mesmo valor das expressões afetivas de Quadros, Pizzio e Rezende (2008, p. 3), todavia, PODRE é um sinal associado ao mundo sensorial, no caso o olfato.

\subsubsection{Marcas de negação e ausência na criação lexical em LSB}

Os sinais identificados nos dados com marcas de negação ou ausência foram: ALEVINO, INVERTEBRADO/INVERTEBRADOS, PRESERVAÇÃO e URBANIZAÇÃO.

Em ALEVINO, a marca de ausência é a sucção das bochechas. Já em INVERTEBRADO/INVERTEBRADOS, além da sucção das bochechas, o movimento é para baixo, ao contrário do movimento do sinal base COLUNA VERTEBRAL que é para cima. A negação que está presente no sinal PRESERVAÇÃO é identificada no movimento negativo com a cabeça e com o sinal NÃO. O sinal URBANIZAÇÃO também usa a sucção da 
bochecha para marcar a ausência de áreas verdes em determinados locais que foram substituídas por edificações.

\subsubsection{Categorias representadas por protótipos}

As categorias encontradas nos dados foram: AVES, transcrita como $\mathrm{BICO}^{\wedge} \mathrm{ASAS}^{\wedge}$ DIVERSOS; PRIMATAS como MACACO $^{\wedge}$ DIVERSOS; FELINOS como BIGODES^DIVERSOS ou; INVERTEBRADOS como INVERTEBRADO^DIVERSOS; MOLUSCOS como CONCHA^CORPO-MOLE^DIVERSOS e VERTEBRADOS como COLUNA-VERTEBRAL^DIVERSOS. Faria-Nascimento (2009) menciona esse mecanismo de categorização na LSB e os nossos dados reforçam a categorização por meio de protótipos.

Encontramos sinais que nomeiam categorias com um ou dois elementos prototípicos de determinado grupo. Os sinais das categorias com apenas um elemento prototípico foram: PRIMATAS, FELINOS, VERTEBRADOS, INVERTEBRADOS, com dois elementos: AVES e MOLUSCOS. A possibilidade de uma categoria ser representada por mais de um elemento prototípico, também foi mencionada por Faria-Nascimento, e esse segundo elemento pode surgir pela necessidade de preencher uma informação mais especializada.

\subsubsection{As criações de sinais por composição}

A composição é um mecanismo de construção de palavras produtivo na LSB. A estrutura fonológica simultânea e linear desta língua permite que muitos sinais juntem duas ou mais bases para criação de um novo sinal. Vários são os exemplos que podemos extrair do nosso corpus, tanto de composição por justaposição, quanto por aglutinação. A seguir, mostramos alguns sinais-termo formados por justaposição e por aglutinação.

- Justaposição: LIXO, POPULAÇÃO, OCEANO e TROVÃO.

- Aglutinação: QUEIMADA, ENERGIA ELÉTRICA, TRANSGÊNICO, DNA, POLUENTE e ANTÁRTICA.

\subsubsection{A motivação por Logotipo}

O logotipo é um símbolo usado para identificação de uma empresa, instituição, marca ou produto. Em LSB, os logotipos podem motivar a criação de sinais. Se tomarmos como exemplos os sinais das instituições de ensino superior UFG e UnB, vemos que os sinais foram 
motivados pelo logotipo que possuem. Em nossos dados, identificamos três sinais motivados pelo logotipo. São eles: RECICLAGEM, RADIOATIVO e ONU quadro 16.

A influência dos logotipos na criação dos sinais foi principalmente nas CMs. No sinal ONU, além de influenciar a CM em "R", os arcos deste símbolo, ou seja, as folhas que envolvem o globo, motivam o movimento do sinal.

\section{Quadro 16 - Sinais motivados por logotipo}

\begin{tabular}{|l|l|}
\hline & \\
\hline $\begin{array}{l}\text { Disponível em: } \\
\text { http://pt.wikipedia.org/wiki/Reciclagem\#mediaviewer/Fil } \\
\text { e:Recycling symbol.svg Acesso em: } 17 \text { dez. 14. }\end{array}$ \\
\hline
\end{tabular}

Fonte: Wikipedia e Infoescola organizado pela autora 


\subsubsection{A metonímia como mecanismo de criação}

Barros e Aguiar (2013) realizaram um breve estudo sobre a metonímia na formação dos nomes de espécies animais na LSB. As autoras identificaram três tipos de processos metonímicos: parte pelo todo, ação pelo agente e combinação de parte pelo todo + ação pelo agente. Organizaremos os nossos dados de acordo com a classificação proposta por elas.

* Parte pelo todo: AVE, AVES, CARANGUEJO variante, LAGOSTA, OSTRA, PANDA, LEOPARDO, LEOPARDO variante, ONÇA-PINTADA, ONÇAPINTADA variante, TATU-BOLA, TIGRE, TIGRE variante e TUBARÃO MARTELO.

* Ação pelo agente: BALEIA, BALEIA-JUBARTE, FOCA, LULA, MICO e SIRI.

Combinação de parte pelo todo + ação pelo agente: ABELHA, ARIRANHA, CAMARÃO, FOCA variante, POLVO, MICO-LEÃO, MICO-LEÃODOURADO, MURIQUI, ORCA e TUBARÃO.

Selecionamos todos os sinais de animais presentes em nossa pesquisa para analisar a presença de processos metonímicos em cada um deles. Os sinais de nomes de animais encontrados foram: ABELHA, ARIRANHA, AVE, AVES, ALEVINOS, BALEIA, BALEIAJUBARTE, CAMARÃO, CARANGUEJO, CARANGUEJO variante, FOCA, FOCA variante, LAGOSTA, LEOPARDO, LEOPARDO variante, LULA, MICO, MICO-LEÃO, MICO-LEÃO-DOURADO, MURIQUI, ONÇA-PINTADA, ONÇA-PINTADA variante, ORCA, OSTRA, SIRI, PANDA, POLVO, TATU-BOLA, TUBARÃO, TUBARÃO MARTELO, TIGRE e TIGRE variante.

Todos os nomes de espécies de animais apresentaram metonímia na constituição do sinal e se encaixaram a classificação utilizada pelas autoras.

\subsubsection{Sinais motivados pela LP}

Partimos dos estudos de Faria-Nascimento (2009) que classificou os empréstimos na LSB em: empréstimo da configuração visual dos lábios (CVL), empréstimos semânticos 
(decalques), empréstimos estereotipados, empréstimos cruzados e empréstimo por transliteração.

O empréstimo por CVL ou, como é mais conhecido na literatura, mouth pattern não foi encontrado nos sinais-termo do MA. Em geral, esse mecanismo é usado para retirar a ambiguidade de itens lexicais como as homonímias manuais. Neste trabalho, procuramos desambiguar os termos da LSB com o uso de sinais-termo diferentes. Desta forma, a CVL tornou-se desnecessária durante a realização dos sinais e até mesmo a evitamos, de acordo com Nascimento e Faulstich (2016, p.49) "não há estudos suficientes para comprovar a sua obrigatoriedade" na LSB.

Quanto aos empréstimos semânticos, identificamos dois sinais: DESENVOLVIMENTO SUSTENTÁVEL e ÁREAS PROTEGIDAS. O último foi considerado decalque apesar de em LSB sofrer uma inversão na estrutura do sinal. A transcrição do sinal ÁREAS PROTEGIDAS poderia ser PROTEÇÃO^ÁREA. Já a transcrição de DESENVOLVIMENTO SUSTENTÁVEL poderia ser DESENVOLVIMENTO^SUSTENTABILIDADE. Esses sinais foram considerados como traduções literais da LP devido a composição lexical que parece estar ao pé da letra. Alves (2007, p. 74) alertou sobre a dificuldade de identificar este tipo de empréstimo.

Nos dados, o único sinal que identificamos como empréstimo estereotipado foi o sinal LAGO. Este sinal desenha um círculo no ar com os dois dedos indicadores apontados para baixo.

Os empréstimos cruzados não foram identificados nos dados, todavia essa constatação já era esperada. Isto porque para a criação dos sinais-termo, primeiramente, foi preciso se compreender os conceitos científicos da área do MA. Os empréstimos cruzados ocorrem quando palavras semelhantes em língua LP - similaridade na grafia das palavras do português - motivam a criação de sinais em LSB, o mesmo sinal passar a ser usado para denotar referentes bastante diferentes apenas pela semelhança das palavras escritas da LP, isto faz com que tenhamos sinais homônimos. Esse tipo de empréstimo seria pouco provável de ocorrer, por tratar-se de um estudo terminológico e a base para criação terminológica, em geral, é o conceito.

Os sinais transliterados, que usam as letras do alfabeto manual na composição dos sinais, foram classificados em transliteração pragmática (datilologia), transliteração lexicalizada e transliteração da letra inicial (inicialização).

Os sinais transliterados identificados de acordo com a classificação de FariaNascimento (2009) foram: BURACO DA CAMADA DE OZÔNIO, CAMADA DE 
OZÔNIO, HIDROGÊNIO, ILHA, OVO, OXIGÊNIO $\left(\mathrm{O}_{2}\right)$, OZÔNIO $\left(\mathrm{O}_{3}\right)$ e PROTOCOLO DE KYOTO. Entre esses sinais temos alguns motivados por suas fórmulas químicas: OXIGÊNIO $\left(\mathrm{O}_{2}\right)$, OZÔNIO $\left(\mathrm{O}_{3}\right)$, BURACO DA CAMADA DE OZÔNIO, CAMADA DE OZÔNIO e HIDROGÊNIO.

Ainda de acordo com essa classificação proposta por Faria-Nascimento, os sinais OVO e PROTOCOLO DE KYOTO são empréstimos por transliteração lexicalizada. Em OVO a parte datilológica está adaptada ao sistema da LSB. Percebemos este fato pela fluidez do sinal ocasionada pela mudança da configuração de mão $\mathrm{V}$ que foi modificada para se acomodar ao sistema linguístico. Wilcox (1992) apud Wilcox e Morford (2007, p. 172-173) já havia apontado a fluidez de uma CM à outra como mecanismo de acomodação dos sinais provenientes de empréstimos datilológicos. Antes de Wilcox, Battison (1978) já mencionava a mudança na CM como uma adaptação de empréstimos datilológicos.

Os sinais por inicialização, denominados por Faria-Nascimento (2009) de empréstimo por transliteração da letra inicial, identificado nos dados foi ILHA.

\subsubsection{Criação de sinais das profissões ou referente à pessoa}

Nos sinais-termo, para dar nome às profissões, a preferência foi a incorporação da ação no corpo e não a marca de pessoa em que se utiliza o sinal de HOMEM ou MULHER, ou mesmo o sinal PROFISSÃO para composição de vários sinais da LSB relativos às profissões. Podemos conferir nos sinais: AMBIENTALISTA, CATADOR DE LIXO, CIENTISTAS e PALEONTÓLOGO essa tendência à incorporação da ação.

Diferente da ASL que possui uma marca para pessoas nos seus sinais, o que mostra as diferentes gramaticas e variabilidade das LS.

\subsubsection{Criação não linear dos sinais-termo do Meio Ambiente em LSB}

Em LP, a especificação dos termos ocorre sempre de forma linear com o acréscimo de palavras à direita do termo. Esta linearidade nem sempre ocorre nos sinais-termo em LSB. Encontramos linearidade nos sinais-termo BALEIA e BALEIA-JUBARTE (figura 60), FLORESTA e FLORESTA-TROPICAL, GÁS e GÁS-CARBÔNICO, MATA e MATA ATLÂNTICA, por exemplo. Todavia, há nesta língua de sinais outros mecanismos gramaticais e visuais para a construção de seus termos. Em LSB, os sinais MICO, MICOLEÃO e MICO-LEÃO-DOURADO não crescem linearmente como em LP, a especificação 
ocorre por meio das ENM, faciais e corporais, e pode haver mudança nos demais parâmetros. No caso de MICO-LEÃO e MICO-LEÃO-DOURADO a especificação ocorre com uma pequena mudança na CM de MICO-LEÃO-DOURADO em que os dedos ficam mais esticados na realização do sinal e os olhos mais abertos em comparação ao sinal MICOLEÃO.

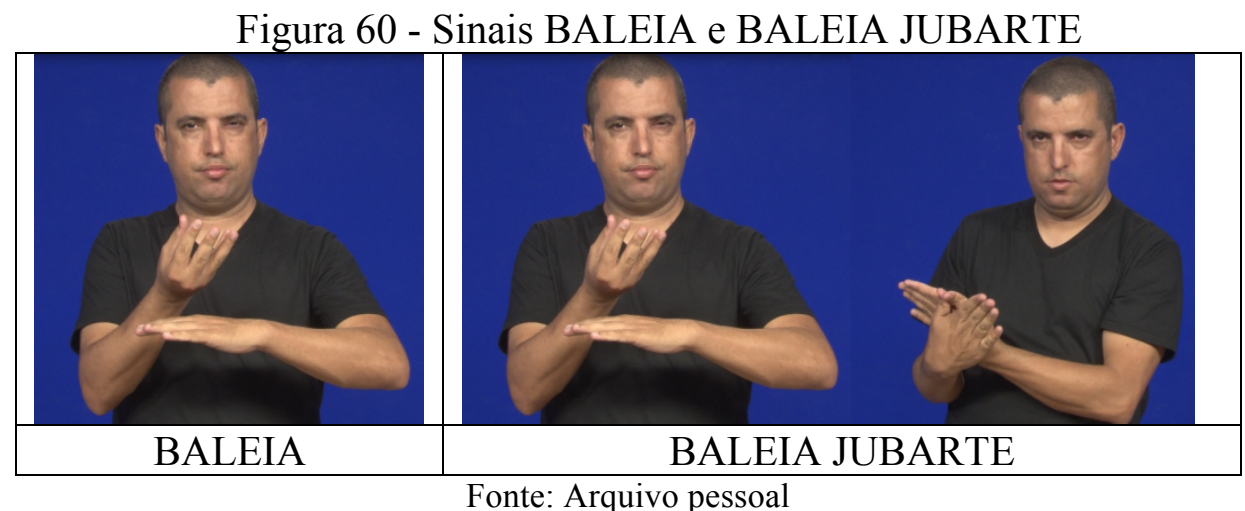

O crescimento do termo pode ser simultâneo, as expressões não manuais podem ser usadas para especificação do termo e não necessariamente aumentará a extensão do termo em LSB, pode haver uma sobreposição de morfemas-base ${ }^{60}$ ou mesmo mecanismos visuais da língua que sejam usados na criação de um novo sinal-termo. Servem de exemplo os sinais OZÔNIO, CAMADA DE OZÔNIO e BURACO DA CAMADA DE OZÔNIO, TUBARÃO e TUBARÃO MARTELO, ENERGIA e ENERGIA ELÉTRICA que mostram a não linearidade na criação dos termos.

Além disso, podemos mencionar a grande quantidade de sinais que em LS é simples e em LP é complexa e vice-versa. Serve de exemplo, o termo pantera que em LP é um termo simples e em LSB é complexo e pode ser transcrito como LEÃO^PRETO.

Isso ocorre porque cada língua possui sua estrutura tanto ao nível do significado quanto do significante e os conceitos - significados - podem não corresponder em todos os contextos. Sobre isto Luque Duran explana:

Cada língua não só distribui diferentes níveis ontológicos entre palavras diferentes, mas também podem marcar distinções específicas que talvez não se encontrem em outras línguas, ou se são encontradas, não necessariamente fazem os mesmos grupos de palavras. O inglês faz distinção entre flesh/meat 'carne viva/carne para comer' e oferece a dupla designação cow/beef, 'vaca/carne de vaca, pig/pork, 'porco/carne de porco', sheep/mutton 'carneiro/carne de carneiro'. O espanhol não faz estas diferenças, no entanto,

\footnotetext{
${ }^{60}$ Conceito de Faria-Nascimento.
} 
distingue pes/pescado 'peixe em seu habitat/peixe vivo ou morto para ser preparado como alimento'. Algumas diferenças entre palavras de línguas distintas se referem às divisões em uma realidade ontológica. $\mathrm{O}$ inglês tem duas palavras para cobrir uma área ground/floor 'chão no exterior de um edifício/chão no interior de um edifício' que é expressa em espanhol por apenas uma palavra suelo'chão'. (LUQUE DURAN, 2001, p. 20-21, tradução nossa) ${ }^{61}$

Nos sinais-termo de nossa pesquisa, percebemos essa realidade mencionada por Luque Duran. Enquanto que em LP existe apenas um termo para clone, em LSB precisamos marcar se é o clone de animal, de um vegetal ou se é humano para adequar-se a gramática da língua. As línguas de sinais possuem em sua estrutura o que vem sendo chamado na literatura de Classificadores (CL).

Os CL são marcadores de coisas, pessoas, animais e vegetais. Faria-Nascimento (2009, p. 117) destaca o papel descritivo e especificador dos classificadores. O termo célula em LSB também precisa receber a marca especificadora se são células de animais, vegetais e humanas. Apesar de que na classificação científica da biologia, os seres humanos fazem parte do reino animal. Nos sinais-termo para clone e células em LSB há diferenças entre clone humano e clone de animais, células humanas e células animais, o que é do homem - animal racional - foi diferenciado dos demais animais irracionais. Weinreich (1984, p. 111) esclarece que: "De fato, enquanto algumas descontinuidades, como entre termos para espécies biológicas discretas, parecem ser (muito, mas não totalmente) determinadas pela natureza, muitas outras são específicas de uma língua-e-cultura". A necessidade de marcar é própria da estrutura da língua.

\subsubsection{Restrições fonológicas: condições de simetria e dominância e mudança da mão dominante}

Nos sinais-termo da área do Meio Ambiente, identificamos alguns sinais que violam as restrições de condição de simetria e de dominância postuladas por Battison (2003, p.22).

\footnotetext{
${ }^{61}$ Texto original: "Cada lengua no solamente reparte diferentes ámbitos ontológicos entre distintas palabras, sino que además estas pueden marcar distinciones específicas que pueden no encontrarse en otras lenguas, o si se encuentran, no lo hacen necesariamente en los mismos grupos de palabras. El inglés distingue entre flesh 'carne viva' y meat 'carne para comer' y ofrece los dobletes designativos cow/beef, pig/pork, sheep/mutton. El español carece de. estas diferencias pero, sin embargo, distingue entre pez y pescado. Algunas diferencias entre palabras de diferentes idiomas se refieren a distintas particiones de una realidad ontológica. El inglés tiene dos palabras ground/floor para cubrir un área que el español expresa solamente con una palabra ('suelo')." (LUQUE DURAN, 2001, p. 20-21).
} 
Os sinais nessas condições são: CONFERÊNCIA DAS PARTES (COP), PAPEL RECICLADO e OSTRA.

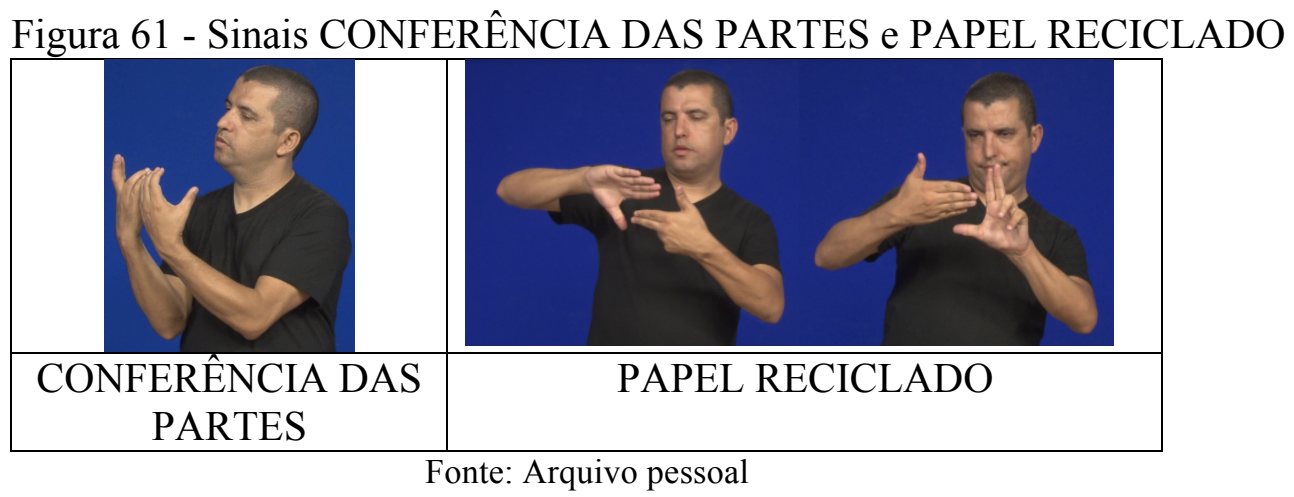

Figura 62 - Sinal OSTRA

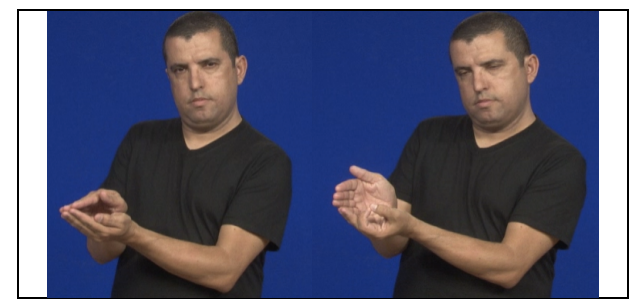

Fonte: Arquivo pessoal

Ao observamos os dados apresentados nas figuras 61 e 62, identificamos uma característica em comum nos sinais que violam as restrições, todos são derivados de um sinal já existente. O sinal CONFERÊNCIA DAS PARTES é motivado pelo sinal REUNIÃO. Este sinal apresenta as duas mãos na CM “R”. Já o sinal CONFERÊNCIA DAS PARTES tem uma das CM em "R" e a outra em "C". A CM "C", neste caso, é uma CM faz menção ao tamanho do referente que é uma reunião de grande porte. Outro exemplo é o sinal PAPEL RECICLADO que é derivado do sinal RECICLAGEM. O sinal PAPEL RECICLADO é constituído por uma $\mathrm{CM}$ que especifica objetos como papel. Esta mesma configuração de mão pode ser encontrada nos sinais PAPEL, DOCUMENTO, TEXTO, etc. O sinal OSTRA segue as mesmas características dos demais, isto porque é derivado do sinal existente CONCHA e é composto na sua estrutura por duas CMs icônicas, uma que remete a concha e outra a pérola.

Em resumo, todos os sinais, que violam as restrições de condição de simetria e de dominância identificados nos dados, têm em comum serem derivados de sinais já existentes, apresentam mudança na $\mathrm{CM}$ de uma das mãos em relação a forma dos sinais que os originaram. 
Além disso, identificamos o fenômeno da mão dominante que se torna não dominante durante a execução de alguns sinais-termo. Os sinais que mudam a mão dominante identificados foram: CÉLULA ANIMAL, CÉLULA VEGETAL, OCEANO RESÍDUO SÓLIDO e RESÍDUO ORGÂNICO, TRÁFICO DE ANIMAIS e USINA NUCLEAR. Apresentamos alguns desses sinais nas figuras 63, 64 e 65 .

Figura 63 - Sinais CÉLULA ANIMAL e CÉLULA VEGETAL

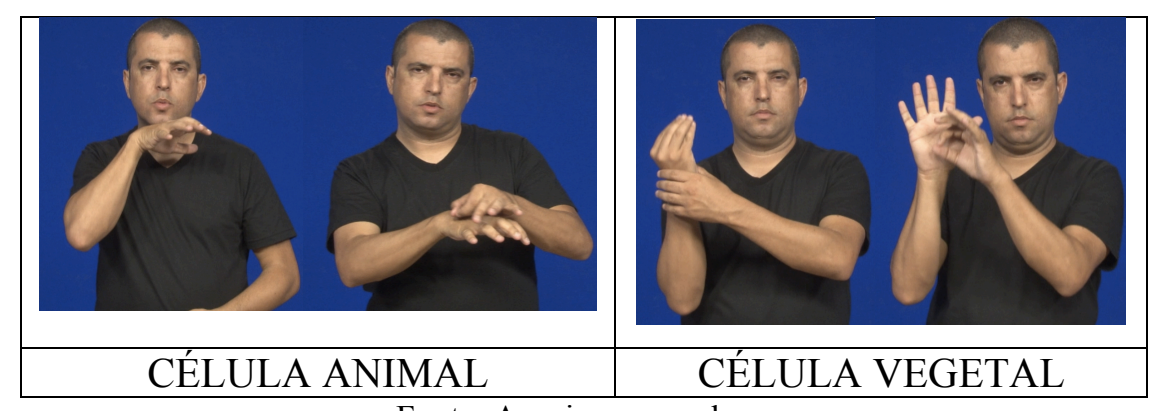

Fonte: Arquivo pessoal

Figura 64 - Sinal RESÍDUO SÓLIDO

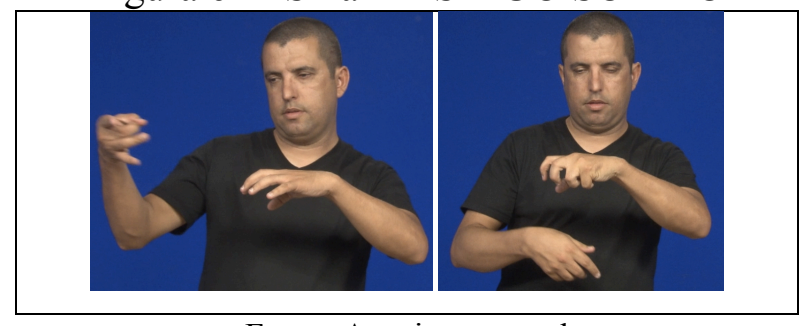

Fonte: Arquivo pessoal

Figura 65 - Sinais TRÁFICO DE ANIMAIS e OCEANO

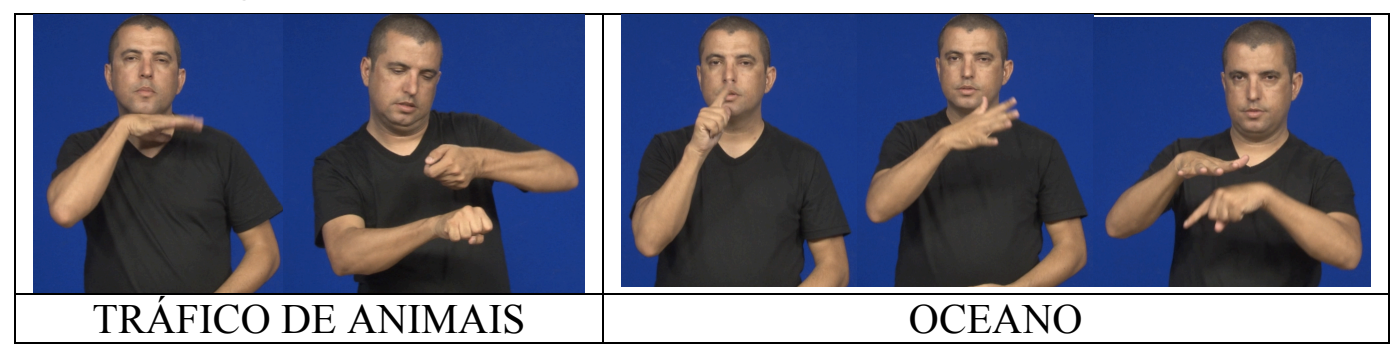

Fonte: Arquivo pessoal

Os sinais mencionados são todos compostos. Em especial, o sinal TRÁFICO DE ANIMAIS foi questionado por um participante, durante as sessões de validação, porque estranhou a mudança de mão ativa na execução deste sinal. Devido a este fato, levantamos a hipótese de que se trata de um sinal em fase de acomodação a língua. Além disso, o sinal TRÁFICO DE ANIMAIS não perdeu movimentos internos ou repetições que é a regra da 
sequência única, uma das três regras morfológicas, propostas por Liddel (1984), para os sinais compostos da ASL, todavia também é válida para os sinais compostos da LSB de acordo com Quadros e Karnopp (2004, p. 104). Em resumo, os sinais que mudam a mão ativa podem estar em fase de acomodação a língua. Sobre este assunto, Battison explica que este fenômeno de mudança de mão em sinais adjacentes, pode ser uma potencial transformação (metamorfose) em sinais compostos (2011, p. 208), o que corrobora a nossa hipótese de que o sinal esteja em fase de acomodação. Talvez, por serem sinais terminológicos, pode ser que permaneçam com a estrutura de mudança de mão ativa afim de que não se perca a informação conceitual, uma vez que é essencial à terminologia. Importa lembrar que esse fenômeno de mudança de mão ativa é bastante comum à sintaxe da LSB.

As restrições fonológicas atípicas da LSB apresentadas, nesta seção, podem ser características mais recorrentes nas linguagens de especialidade desta língua como alternativa para criação de sinais compostos de menor extensão e mais fluidos.

\subsection{Procedimentos para padronização e edição das filmagens}

Durante as filmagens da versão final dos sinais-termo, levamos em conta o nível formal da linguagem, o controle da velocidade da sinalização, o posicionamento em frente à câmera e a manutenção de um mesmo padrão para sinais com estruturas semelhantes.

Para mantermos o nível formal da linguagem, retiramos marcas que pudessem infantilizar os termos, tornar a gestualidade excessiva, repetições do mesmo movimento em um sinal, caso a repetição ocorresse mais do que 3 vezes e primamos pelo uso do espaço mais contido. O corpo do sinalizante aparece no vídeo do quadril para cima como ilustra a figura 65. Os excessos no uso do espaço podem ser considerados até mesmo como falta de educação, segundo Quadros (2009) ${ }^{62}$. O uso correto do espaço é um importante componente para o uso formal da linguagem.

\footnotetext{
${ }^{62}$ Opinião de Ronice Quadros durante a defesa pública de tese de doutorado de Sandra Patrícia Faria do Nascimento em que foi membro da banca examinadora.
} 
Figura 66 - Enquadramento do sinalizante no vídeo

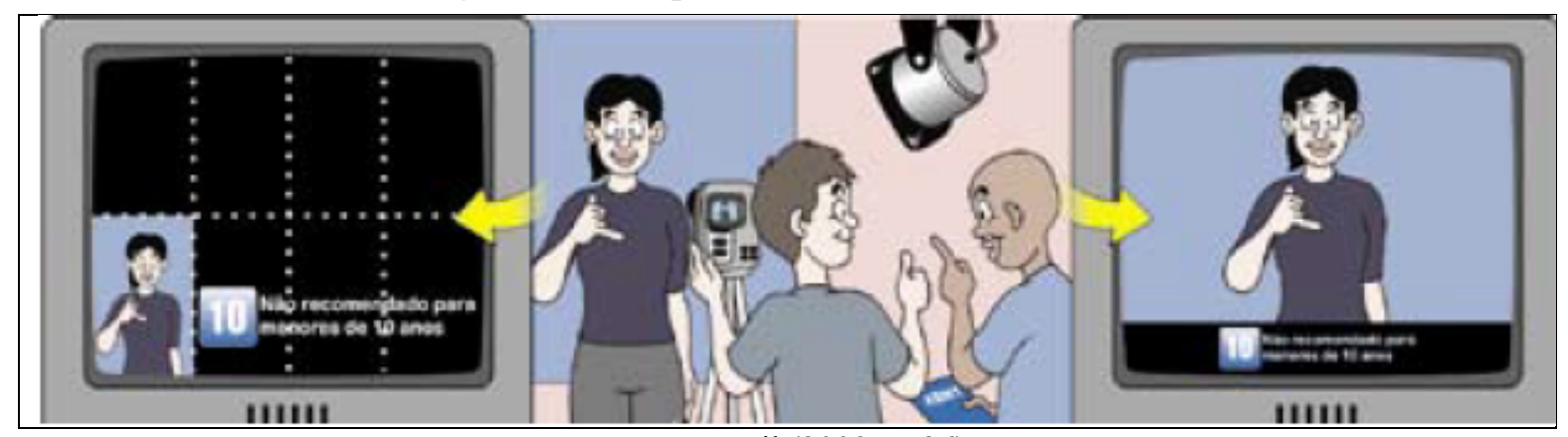

Fonte: Brasil (2009, p. 26)

A ilustração mostra o enquadramento do sinalizante na tela da televisão, mas poderiam ser outras telas como a do computador, tablet etc. Mantivemos a atenção ao enquadramento para que os braços e a cabeça não fossem cortados durante a movimentação da execução dos sinais, para que os dedos e outras partes do corpo não ficassem de fora do espaço delimitado.

Discordamos do enquadramento do sinalizante na cartilha "Classificação Indicativa na Língua Brasileira de Sinais" (BRASIL, 2009) que sugerem o foco da cintura para cima. No nosso glossário, o recorte foi acima da altura do quadril. Embora o material sugira que o enquadramento seja da cintura para cima, as ilustrações contidas na cartilha, em sua maioria, apresenta o sinalizante da altura do quadril para cima.

É necessário investigar os limites dos gestos e das ENM que compõem os sinais da língua de sinais brasileira e os traços que caracterizam a linguagem formal desta língua. Pois, diferentemente de outros contextos, como das artes e teatro, que se podem explorar mais as expressões faciais, corporais e o uso do espaço, na linguagem formal o espaço de sinalização é mais contido.

Fizemos uma seleção das filmagens e foram excluídos os vídeos que apresentavam expressões não manuais exageradas. Os vídeos sem ENM também foram eliminados em alguns casos porque eram componentes importantes do sinal. Em alguns momentos, notamos que o excesso de ENM tirou a seriedade do trabalho, tornando o sinal-termo até engraçado e tivemos dificuldades em diversos momentos de ter ENM equilibradas e adequadas a cada sinal e ao glossário como um todo.

Nas sessões de validação, como já mencionamos, os participantes criticaram muito algumas expressões faciais que julgaram ser inadequadas aos sinais apresentados. Em alguns casos, consideraram as expressões exageradas e, em outros, consideraram que as expressões da face não condiziam com o referente. Serve de exemplo o sinal OURO que, ao invés de 
abrir mais, os olhos foram fechados. Todavia a ausência das ENM também afetou o sentido completo dos sinais-termo.

Há também sinais como TIGRE e ONÇA-PINTADA que podem usar uma mão ou duas mãos para a execução do sinal. Para a padronização dos sinais semelhante no glossário, usamos apenas uma das mãos, embora o nível formal seja mantido nas duas formas.

\subsection{Síntese do capítulo}

Neste capítulo, descrevemos os estudos e pesquisas realizados até chegarmos aos sinais-termo que compõem o glossário. Além disso, apresentamos uma análise preliminar dos mecanismos de criação encontrados nos sinais-termo do Meio Ambiente. Em síntese, os mecanismos e os elementos associados à criação de sinais apresentados foram: os morfemasbase, as marcas de plural, as expressões não manuais, as marcas de negação, a categorização por protótipos, a criação de sinais por composição, a motivação por logotipo, a metonímia, sinais motivados pela LP, criação de sinais das profissões ou referente à pessoa, criação não linear dos sinais-termo, as restrições fonológicas e a mudança da mão dominante. Todavia ainda há muito para se explorar dos dados. Também retratamos os critérios utilizados durante as filmagens para manter a formalidade e a padronização dos dados. 


\section{CAPÍTULO 5: O MODELO DO GLOSSÁRIO ILUSTRADO SEMIBILÍNGUE}

\subsection{Introdução}

Neste capítulo, apresentamos nossa proposta de glossário e o funcionamento da obra. Apresentamos, de início, as singularidades do público-alvo que contribuíram para a composição do glossário e aspectos da descrição fonológica dos sinais-termo para a busca pela LSB.

\subsection{As idiossincrasias linguísticas dos surdos e suas implicações no glossário}

A nossa proposta de glossário ilustrado semibilíngue do Meio Ambiente, em mídia digital, recebeu o nome de "Glossário Ilustrado do Meio Ambiente Libras-Português" (GIMALP). O GIMALP tem como público-alvo surdos do Ensino Fundamental II do $6^{\circ}$ ao $9^{\circ}$ anos, na faixa etária de 11 a 14 anos. As características dessa obra lexicográfica foram pensadas para atender às singularidades do público mencionado e, por isso, procuramos inserir no glossário os elementos considerados essenciais que são: a presença da Língua de Sinais Brasileira, o uso de recursos visuais para explorar e desenvolver a visualidade e, sempre que possível, adaptar a Língua Portuguesa a uma linguagem mais corrente, já que para os consulentes do GIMALP, a LP é uma segunda língua (L2). Esses são os três pontos fundamentais na concepção dessa obra.

A seguir, apresentamos mais detalhadamente os três principais parâmetros que compõem as LS e como esses elementos estão representados visualmente no GIMALP. Em sequência, mostramos os esforços e as estratégias para reduzir a extensão do texto definitório e a complexidade vocabular.

\subsubsection{A língua de sinais e a visualidade dos surdos}

As Línguas de Sinais são visuais e essa visualidade é expressa em todos os níveis linguísticos. Para o acesso aos sinais-termo do GIMALP pela LSB, os consulentes precisam conhecer os principais parâmetros dessa língua, a saber: configuração de mão, ponto de articulação e movimento. O acesso a esses parâmetros no glossário dá-se por meio de desenhos de duas pesquisas diferentes - as CMs que são oriundas da pesquisa de Faria- 
Nascimento (2009) e os PAs e M, do trabalho de Barros (2015). Os consulentes já começam a treinar a visualidade a partir dos desenhos que são ícones de busca do GIMALP, tomando consciência das diferenças de uma CM para outra, de um PA para outro ou de um movimento para outro - o que contribuirá para uma fixação de sua primeira língua. Esse aspecto é importante na educação bilíngue e favorece o ensino da LSB como língua "materna".

Primeiramente, apresentamos o quadro com as $75 \mathrm{CMs}$ sistematizadas por FariaNascimento (2009). As CMs estão organizadas de forma lógica, pois seguem a sequência CM mais fechada para a mais aberta. Esses formatos de mãos servem como ícones de busca do GIMALP. Vale esclarecer que ícone, aqui, significa uma representação dos formatos de mão adquiridos na execução do sinal, dos locais onde os sinais são realizados e dos movimentos dos sinais, em forma de imagens, para se chegar aos sinais-termo desejados do glossário.

Figura 67 - Quadro de CMs de Faria-Nascimento (2009)

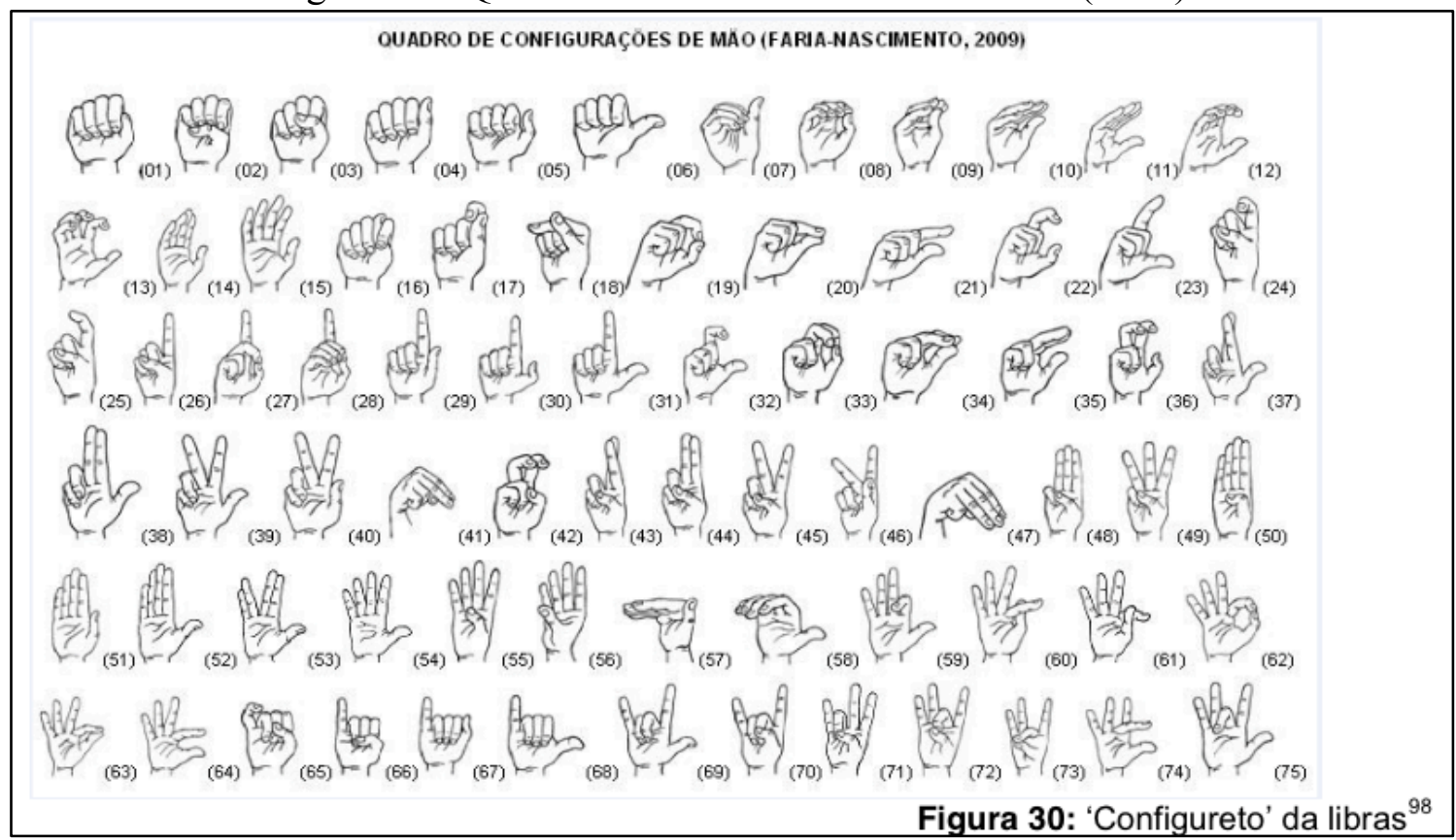

Fonte: Faria-Nascimento (2009 apud Faria-Nascimento; Nascimento, 2010, p. 45)

Os 35 pontos de articulação foram catalogados por Barros para o seu sistema de escrita denominado ELiS. Esses ainda podem ser subdividos em grupos de PA na cabeça, tronco, membros e mão. Em nosso glossário, os desenhos dos PAs servem como ícones de busca desse parâmetro e foram retirados do livro de Barros (2015) feitos para explicar a ELiS. Antes de mostrarmos a sistematização dos PAs e suas respectivas ilustrações, apresentamos as informações contidas nos desenhos. 
Figura 68 - Ícone do PA nariz

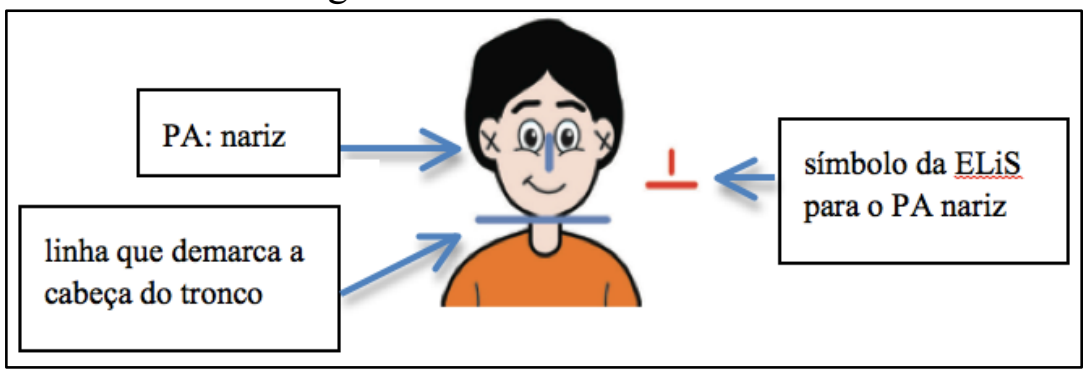

Fonte: Elaborada pela autora, a partir da ilustração de Barros (2015)

Quadro 17 - Locações segundo Barros (2015)

(18. alto da cabeça




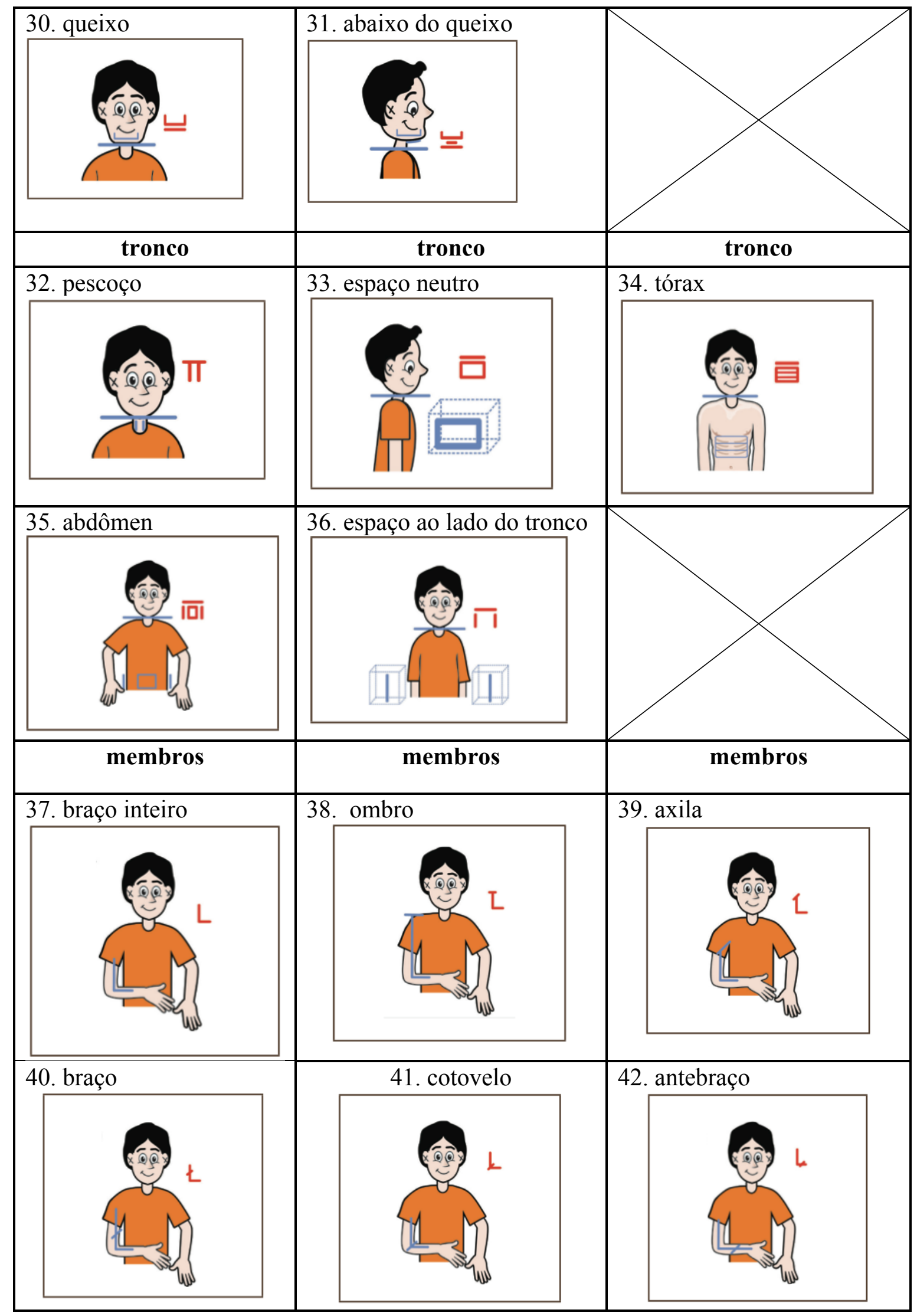




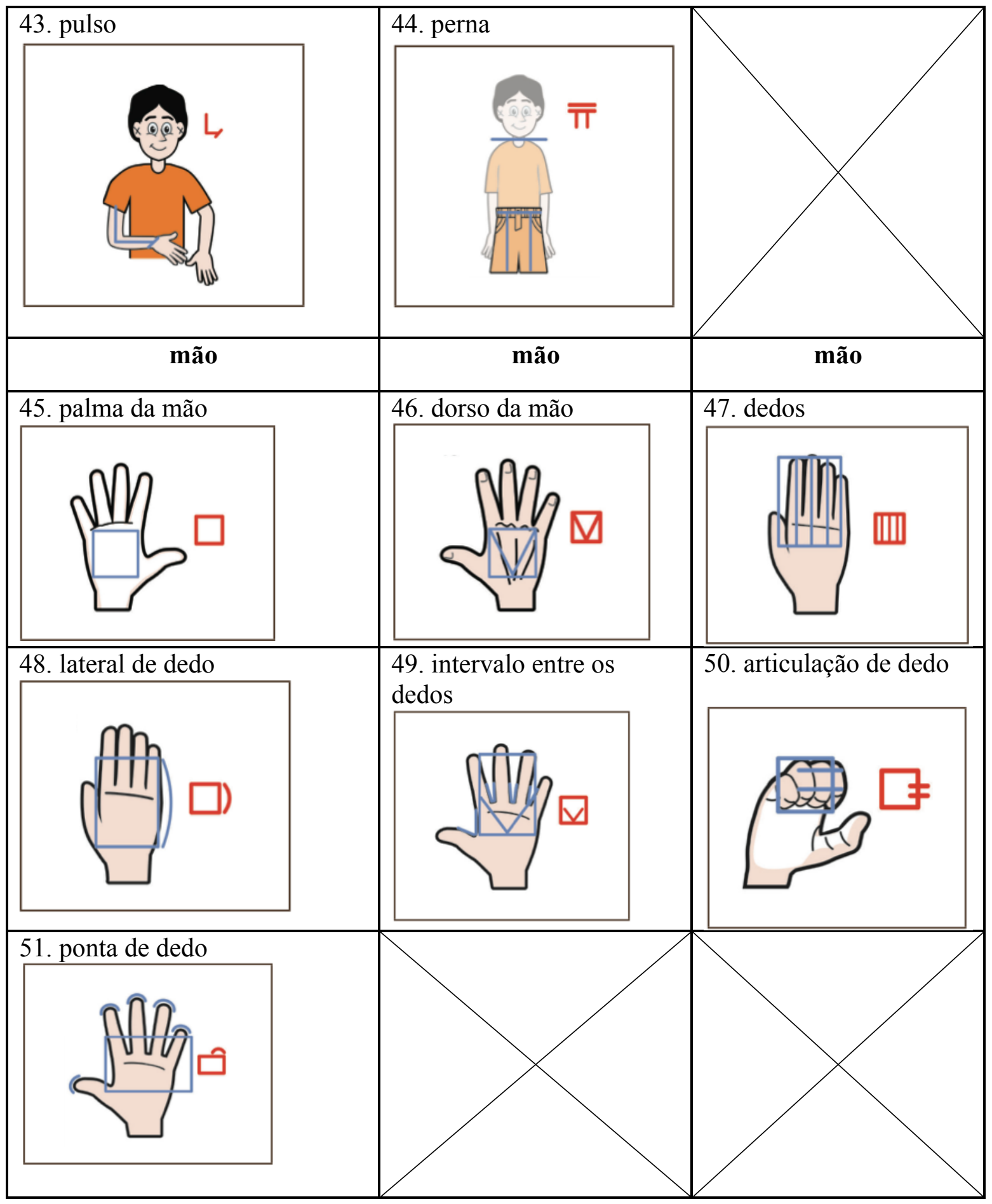

Fonte: Elaborado pela autora, a partir do livro de Barros (2015)

Os 44 movimentos (M), também organizados por Barros, podem ser divididos em $\mathrm{M}$ de braços, $\mathrm{M}$ de dedos e punho e $\mathrm{M}$ sem as mãos. Os desenhos dos movimentos que servem de ícones de busca desse parâmetro são mostrados a seguir. Antes, mostramos as informações contidas nos desenhos. 
Figura 69 - Representação do ícone do movimento de fechar a mão

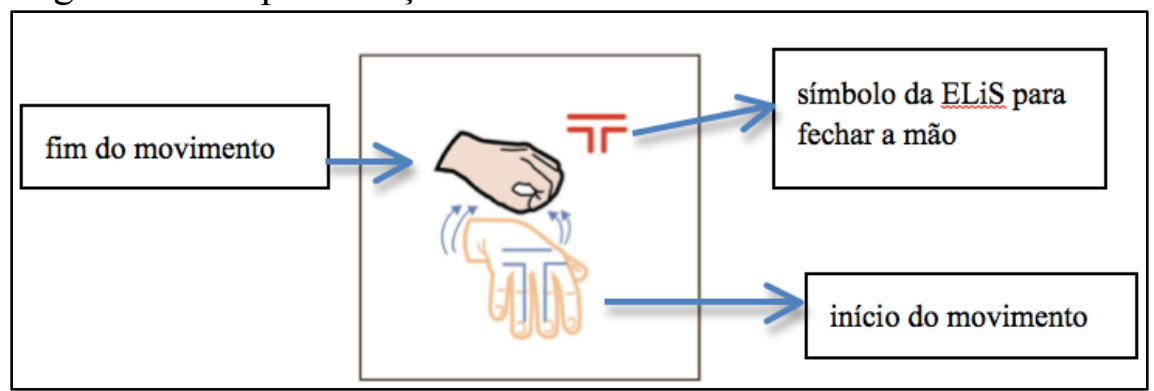

Fonte: Elaborada pela autora, a partir da ilustração de Barros (2015)

Quadro 18 - Movimentos segundo Barros (2015)

movimentos de braço




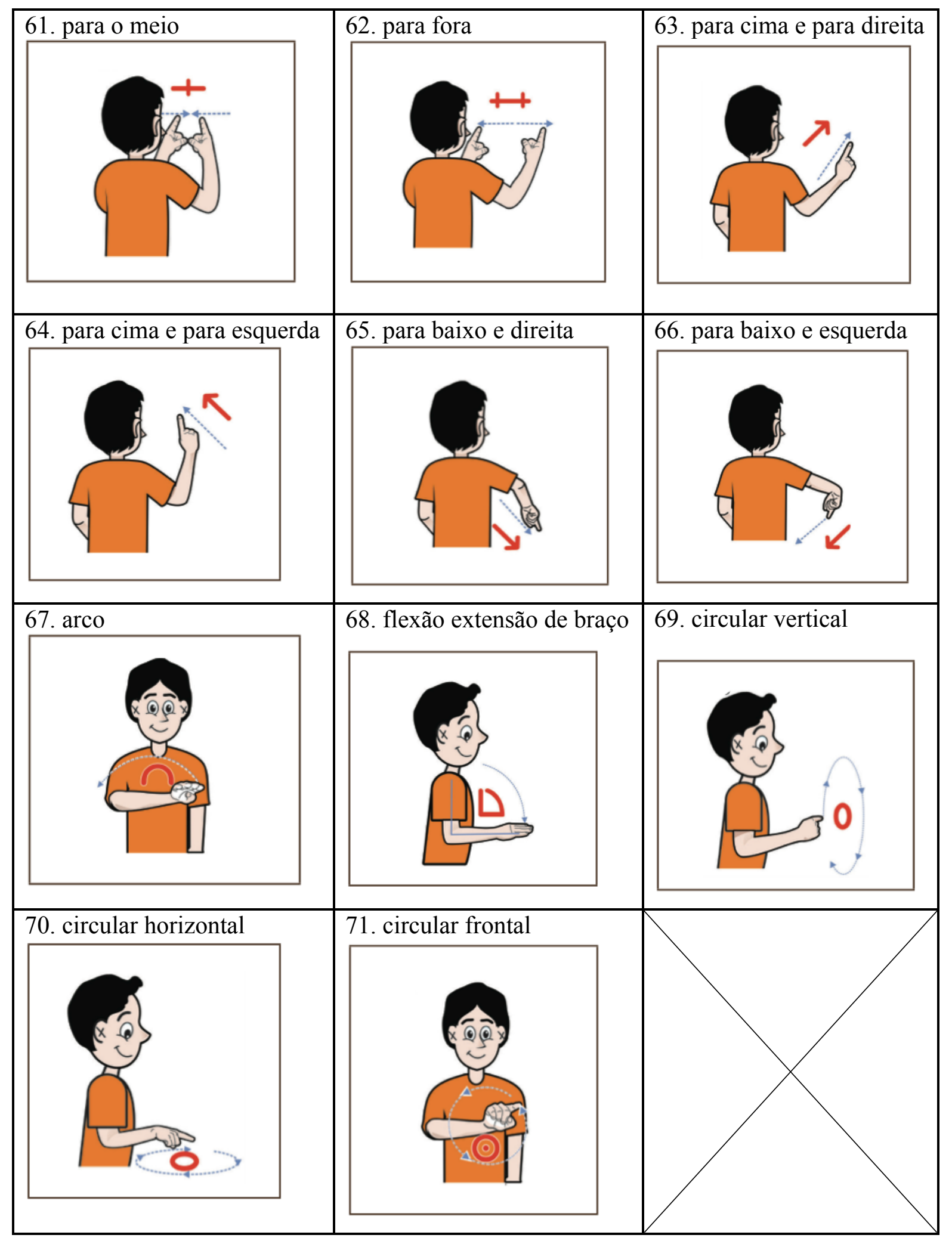




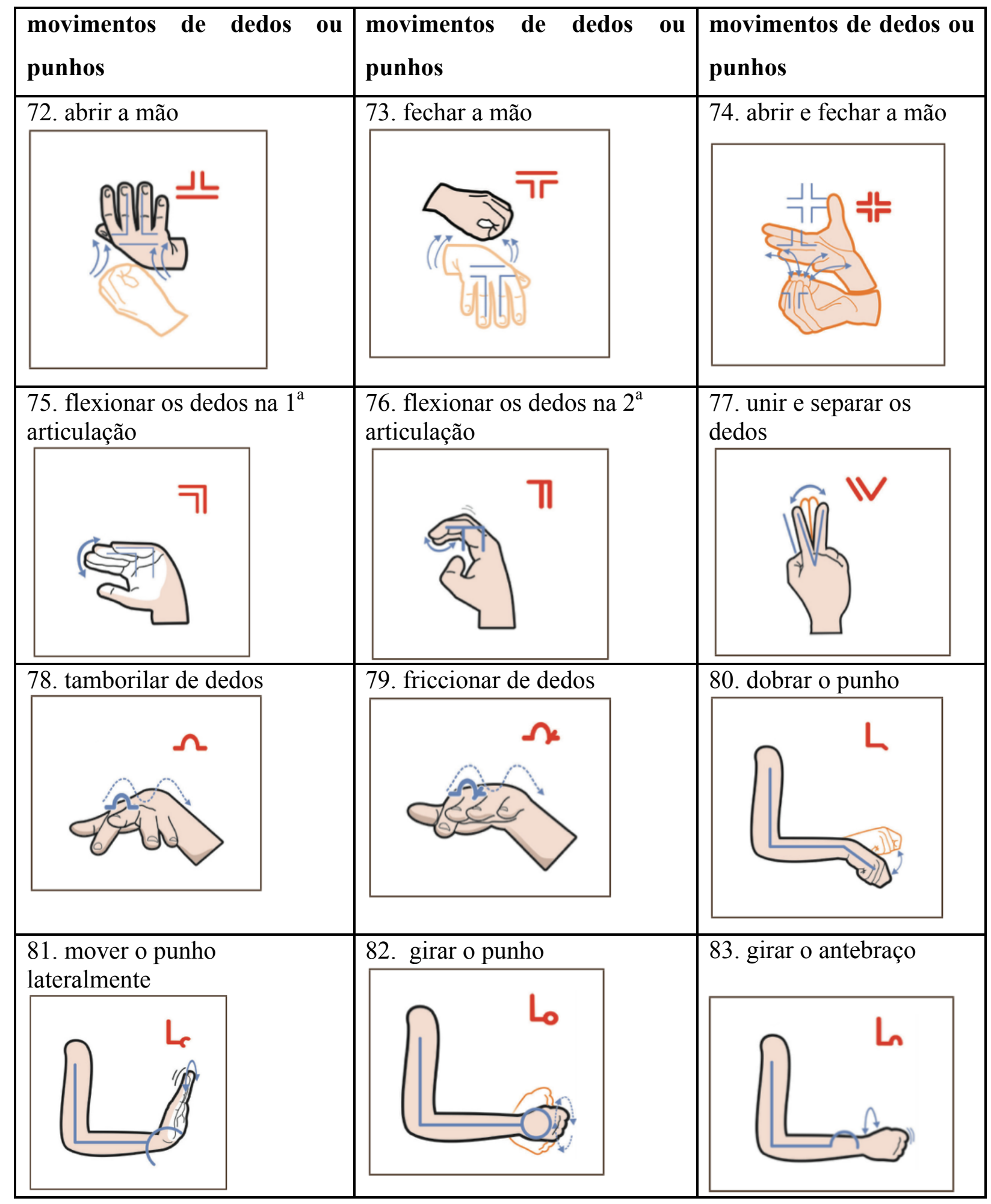




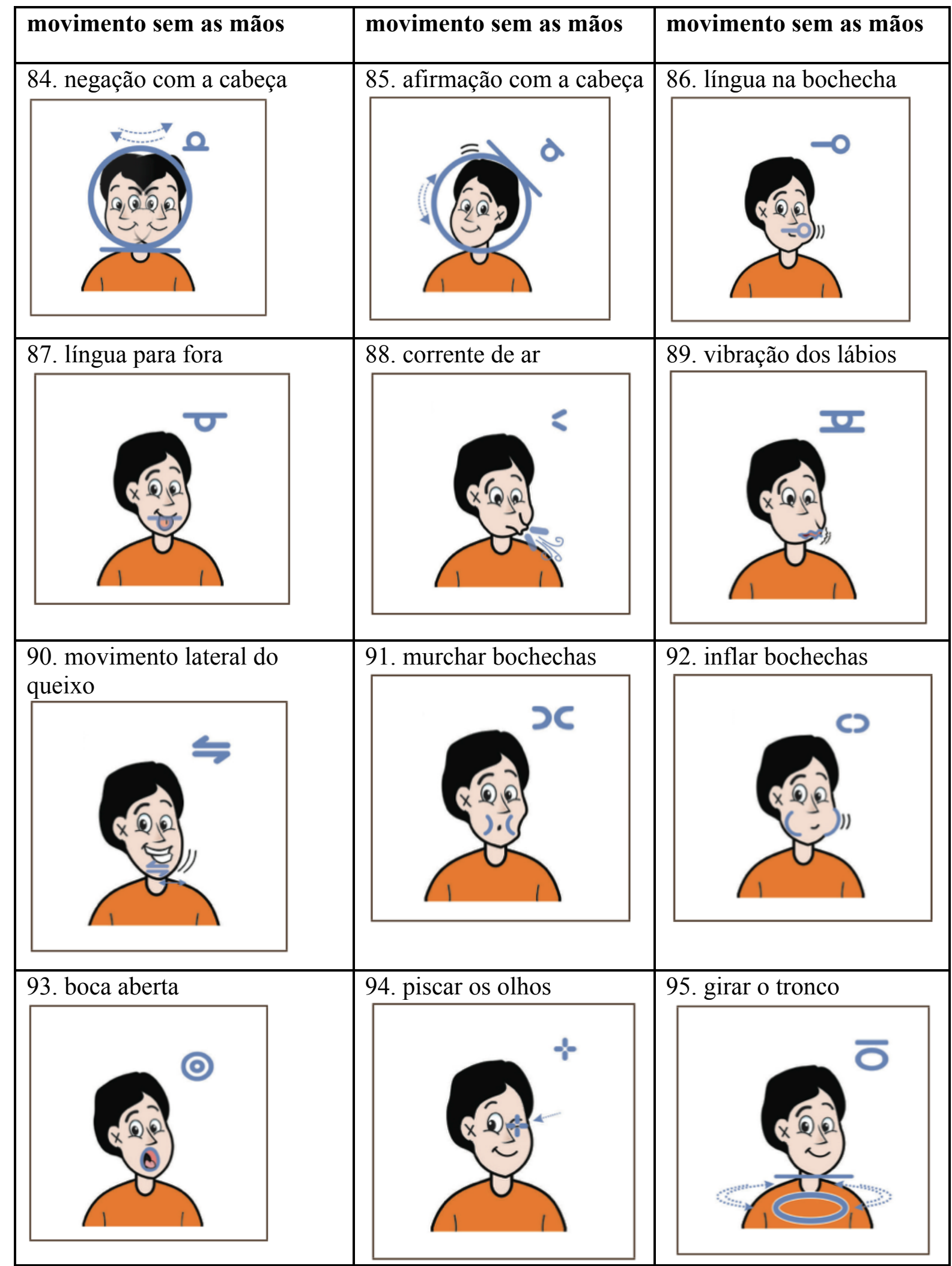

Fonte: Elaborado pela autora, a partir do livro de Barros (2015)

Os desenhos das configurações de mão, dos pontos de articulação e dos movimentos são bastante icônicos, o que facilita a associação entre o parâmetro e a ilustração correspondente. Essa característica é positiva para o consulente que poderá depreender as 
informações visualmente sem precisar de muitas explicações, tendo em vista que a maioria das ilustrações são autoexplicativas.

\subsubsection{Português como L2 para surdos}

O Português é oficialmente considerado uma segunda língua - L2 - para os surdos no Brasil, todavia, ainda há um longo caminho a percorrer a fim de desenvolver metodologias de ensino e criar materiais específicos em L2 para esse público.

$\mathrm{Na}$ tentativa de criar um material que tenha a LP mais adequada aos surdos, alguns esforços foram empregados, como a reformulação das definições e a adaptação da linguagem ao público-alvo. Ambos os procedimentos foram apresentados no capítulo de metodologia desta pesquisa.

Para a reformulação das definições, o método de decomposição de interpretantes que criamos, a partir do postulado de Finatto (2001), foi de fundamental importância para a seleção das informações mais relevantes da definição, o que contribuiu de forma positiva na redução da extensão do texto definitório.

Outra estratégia que usamos foi acrescentar os tipos às definições, a fim de que os consulentes façam uma referência direta com o mundo real. Servem de exemplo as definições de combustível fóssil, ecologia, erosão e felino. Na definição do termo combustível fóssil são apresentados alguns tipos de combustíveis fósseis, como o petróleo, o gás natural e o carvão. Já na definição de ecologia aparecem tipos de seres vivos como as plantas, os animais e as pessoas. Ademais, em erosão, os tipos aparecem quando listamos os agentes naturais como o vento, a água, a chuva e as ondas. Para finalizar a exemplificação de uso dos tipos nas definições, no termo felino, citamos vários deles: gatos domésticos, gatos selvagens, jaguatirica, onça-pintada, onça-parda, leão e tigre. Essa estratégia serve tanto para fazer uma referência com o mundo real que o surdo conhece quanto para introduzir novas palavras e novos conhecimentos.

A substituição de palavras foi outra estratégia com a finalidade de reduzir a complexidade vocabular e adequar-se melhor à condição de uma segunda língua e à faixa etária dos consulentes. O critério para substituição foi o uso de uma linguagem mais corrente, mais próxima da leitura dos surdos.

Apresentamos o quadro 19, apenas a título de exemplificação, com algumas substituições vocabulares feitas durante as reformulações das definições. A seleção de palavras para trocar por uma outra ou por uma frase é, sem dúvida, uma tarefa árdua e requer 
cuidado para não prejudicar o conteúdo informado ou usar a LP incorretamente, na tentativa de auxiliar o usuário do glossário.

Para contribuir com mais pistas, as ilustrações associadas aos verbetes têm a função de facilitar o entendimento da linguagem verbal contida na definição. Além disso, o uso de materiais visuais na educação de surdos é a recomendação mais frequente para atingir o público-alvo na relação de ensinar e aprender.

Quadro 19 - Substituição vocabular

\begin{tabular}{|l|l|}
\hline Palavras ou trechos originais & \multicolumn{1}{|c|}{ Substituição } \\
\hline insípida & sem sabor \\
\hline vagaroso & lento \\
\hline ramo da Biologia & área da Biologia \\
\hline homeotermos & temperatura mais ou menos constante \\
\hline danosa aos animais & que pode prejudicar os animais \\
\hline dimensões & tamanhos \\
\hline elevação & aumento \\
\hline
\end{tabular}

Fonte: Elaborado pela autora

\subsection{Descrição fonológica dos sinais-termo para a busca pela LSB}

A descrição fonológica dos sinais-termo da área do Meio Ambiente é uma das etapas dos procedimentos metodológicos previstas para a criação da proposta do GIMALP. Essa descrição foi realizada a partir dos parâmetros configuração de mão, organizado por FariaNascimento, ponto de articulação e movimentos organizados por Barros, todos apresentados na subseção 5.2.1.

Fizemos a descrição fonológica dos 50 sinais-termo que são apresentados em nossa proposta de glossário online. A lista dos 50 termos pode ser encontrada na subseção 5.4.3 deste capítulo.

É válido lembrar que essa descrição contempla apenas o início de cada sinal, isto significa dizer a(s) primeira(s) $\mathrm{CM}(\mathrm{s})$ dos sinais, o(s) primeiro (s) movimento(s) que aparece $(\mathrm{m})$ simultaneamente e o ponto de articulação inicial dos sinais. Apresentamos, a seguir, a descrição fonológica de alguns sinais, todavia, os demais sinais descritos podem ser conferidos no Apêndice E. 
Para mostrarmos a análise do início dos sinais, criamos fichas para inserir a descrição fonológica. Identificamos em nossos dados, cinco diferentes tipos de sinais que apresentamos nas fichas, representando os diferentes tipos de sinais de acordo com suas características. Organizamos os sinais da seguinte forma: 1) Início do sinal realizado com apenas uma das mãos; servem de exemplo os sinais ÁGUA DOCE (figura 70) e GELO (figura 71 ). 2) Início do sinal realizado com duas mãos iguais ativas, como, por exemplo, o sinal FELINO (figura 72). 3) Início do sinal realizado com duas mãos diferentes, todavia uma das mãos é a dominante e a outra não dominante - isto significa dizer que o sinal está em condição de dominância, como o sinal FURACÃO (figura 73). 4) Início do sinal realizado com duas mãos iguais, mas que o sinal está em condição de dominância - tem uma mão dominante e a outra não dominante -; serve de exemplo o sinal AQUECIMENTO GLOBAL (figura 74). 5) Início do sinal realizado com duas mãos diferentes, mas que ambas são ativas, como no sinal PAPEL RECICLADO (figura 75).

Mostramos, a seguir, as fichas de análise fonológica preenchidas de acordo com os parâmetros constituintes de cada sinal. Alguns esclarecimentos são necessários antes de apresentarmos as fichas. A busca pelo sinal é composta das seguintes opções: PA = ponto de articulação, $\mathrm{CM}_{1}=$ configuração de mão $1, \mathrm{CM}_{2}=$ configuração de mão $2, \mathrm{M}_{1}=$ movimento 1 e $\mathrm{M}_{2}=$ movimento 2, como demonstrado no quadro 20. Esse mecanismo de busca é apresentado com mais detalhe na subseção 5.4.1.

Quadro 20 - Ficha dos parâmetros iniciais para a descrição fonológica dos sinais-termo

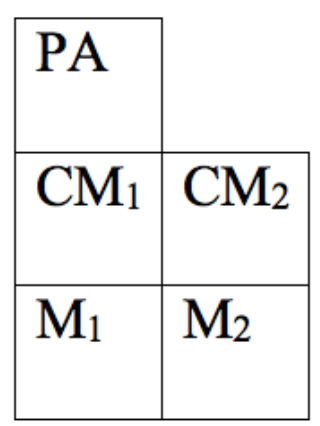

Fonte: Elaborado pela autora 
Figura 70 - Descrição dos parâmetros iniciais do sinal ÁGUA DOCE

2. água doce

PA: queixo (30)

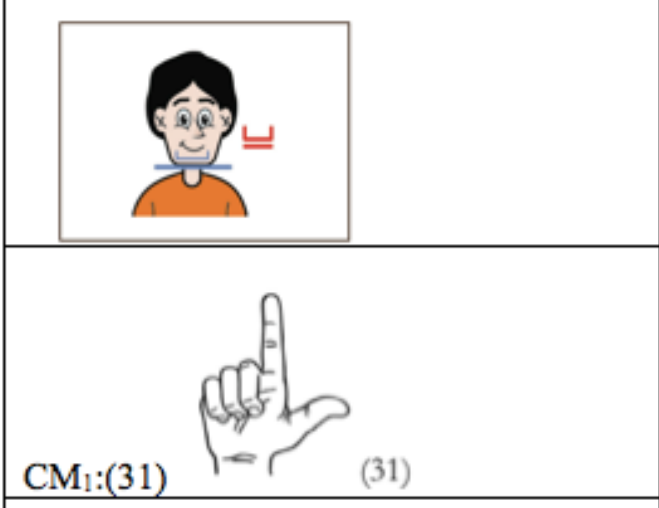

$\mathrm{M}_{1}$ : flexão do dedo na $1^{\mathrm{a}}$ articulação (75)

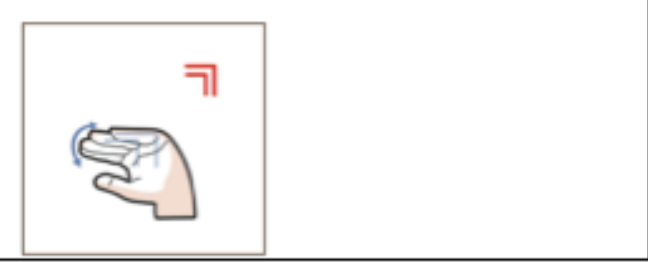

Fonte: Elaborada pela autora

Figura 71 - Descrição dos parâmetros iniciais do sinal GELO

32. gelo

PA: queixo (30)

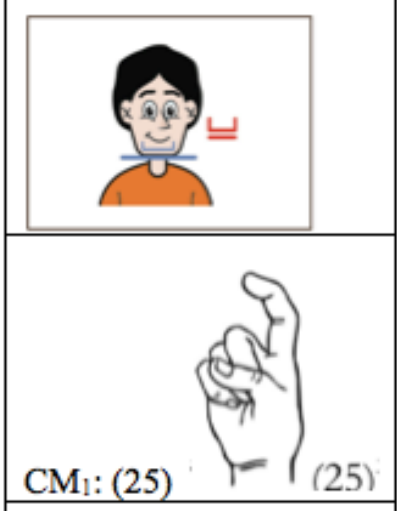

$\mathrm{M}_{1}$ : sem movimento

Fonte: Elaborada pela autora 
Figura 72 - Descrição dos parâmetros iniciais do sinal FELINO

\section{8. felino}

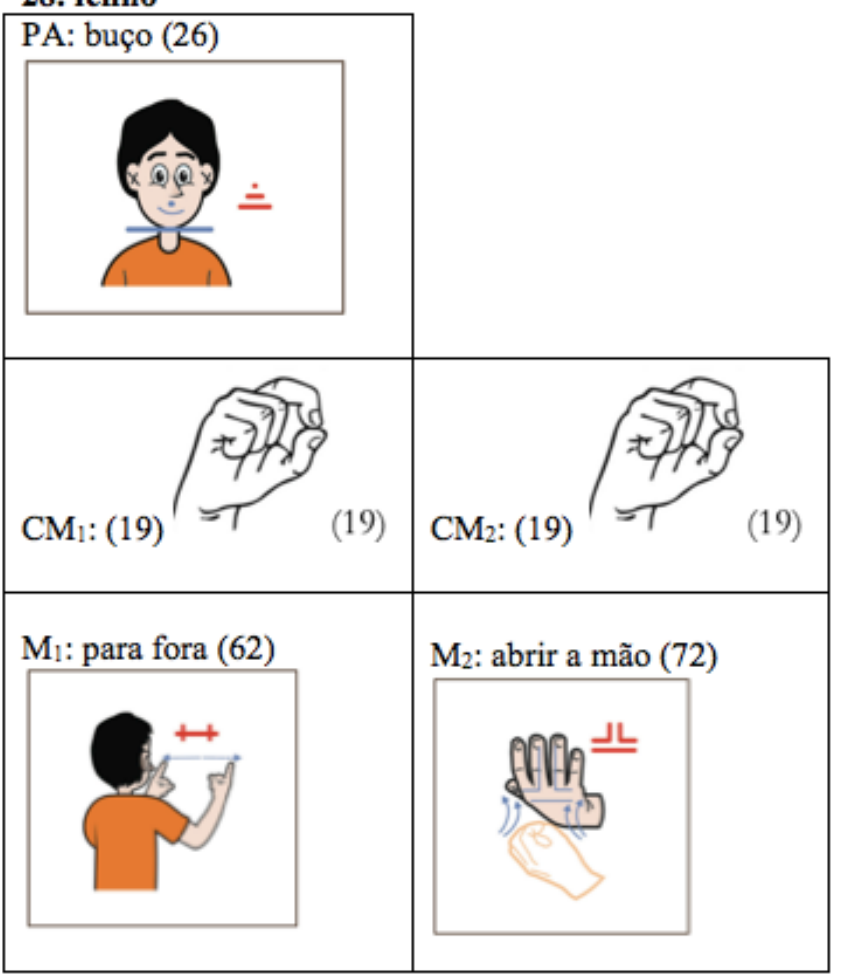

Fonte: Elaborada pela autora

Figura 73 - Descrição dos parâmetros iniciais do sinal FURACÃO

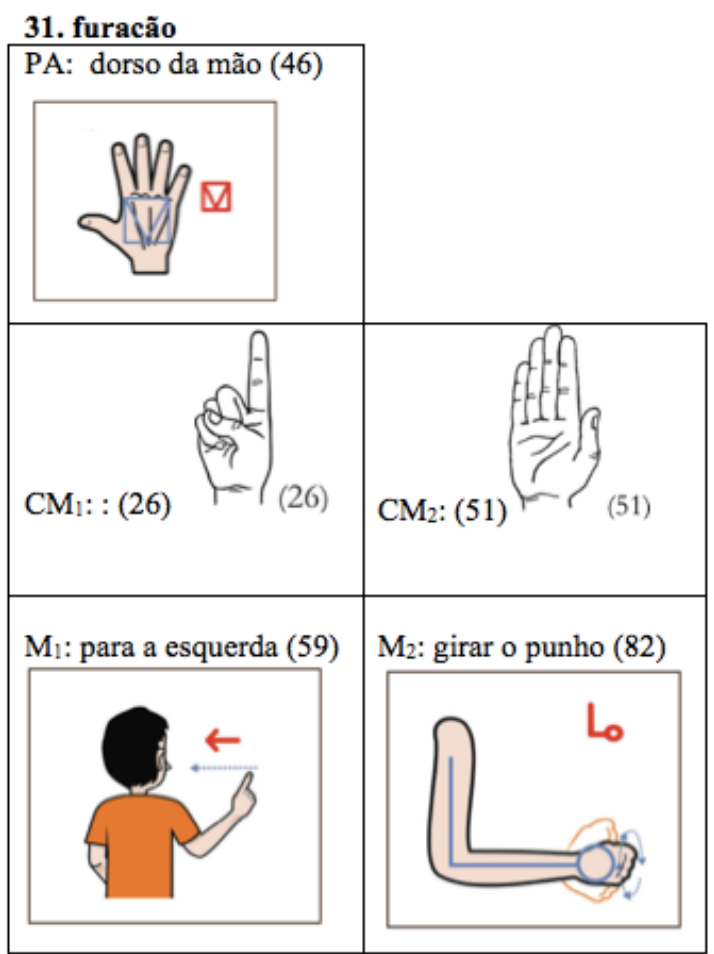

Fonte: Elaborada pela autora 
Figura 74 - Descrição dos parâmetros iniciais do sinal AQUECIMENTO GLOBAL

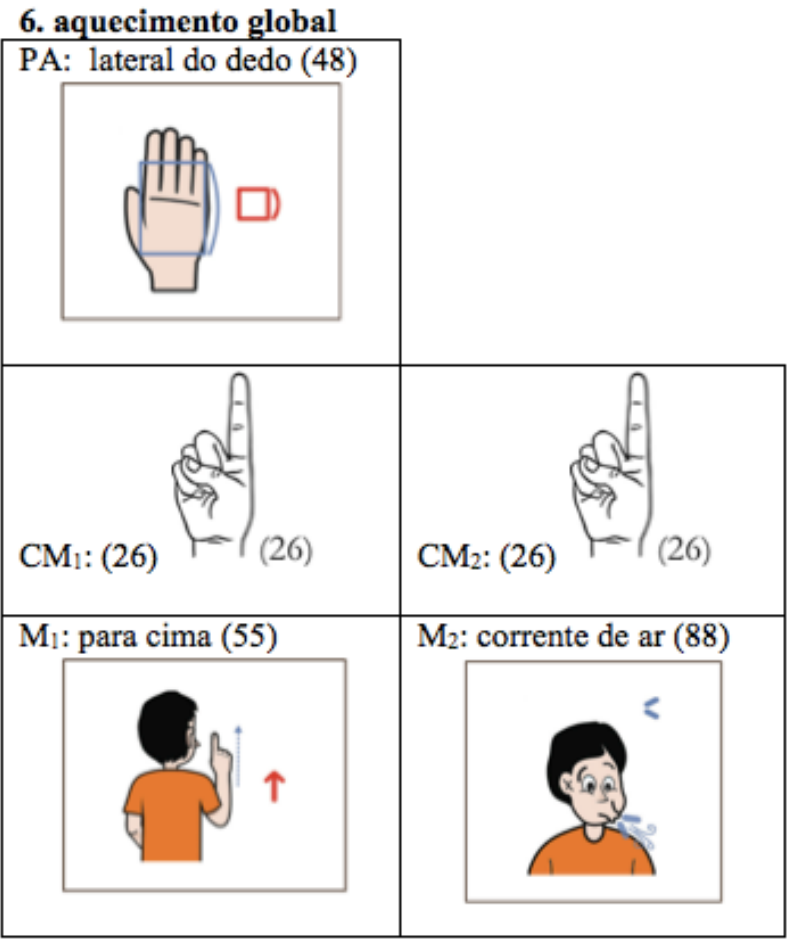

Fonte: Elaborada pela autora

Figura 75 - Descrição dos parâmetros iniciais do sinal PAPEL RECICLADO

41. papel reciclado

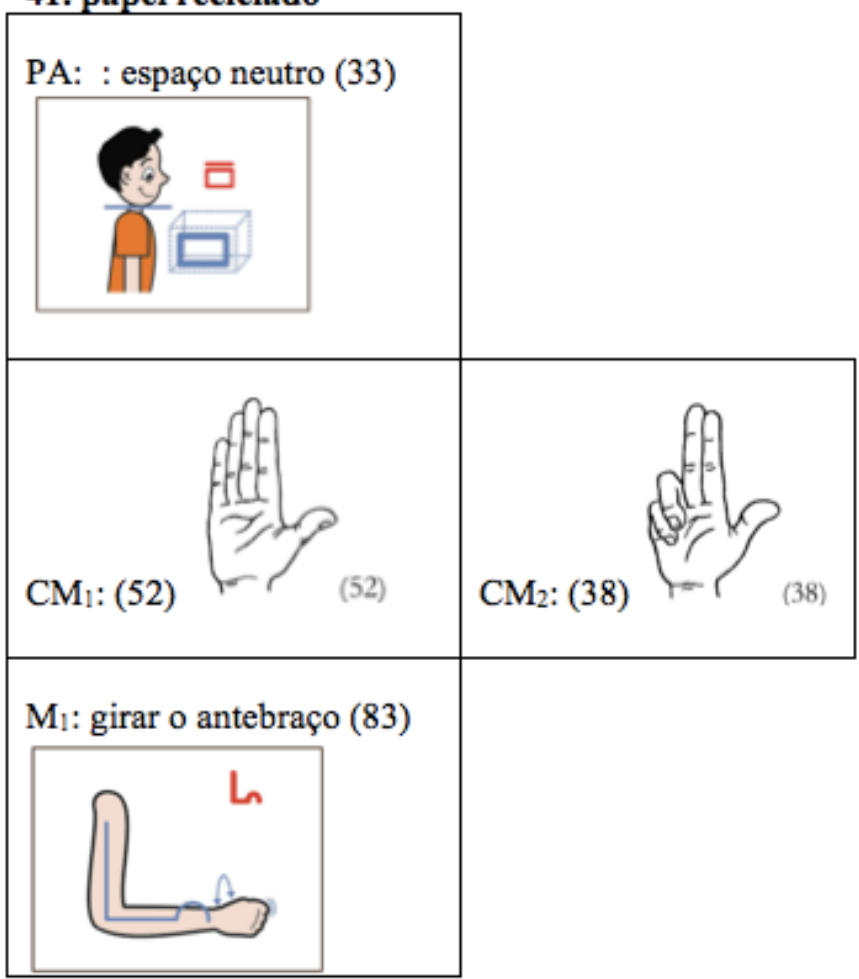

Fonte: Elaborada pela autora 
Durante a descrição fonológica, deparamo-nos com problemas como: a dificuldade na escolha das CMs semelhantes, a dúvida se o sinal seria cadastrado como localizado no espaço neutro ou o ponto de articulação seria a outra mão e, ainda, como organizar e selecionar mais de um movimento simultâneo.

A diversidade de CMs em alguns momentos dificultou a escolha desse parâmetro, como no exemplo o sinal URBANIZAÇÃO (figura 76). Na análise da mão não dominante, tivemos dificuldade em saber qual seria a melhor CM correspondente a esse sinal - a CM 51, 52 ou 54? Decidimos pela CM 51 com os dedos todos juntos, contudo, é possível que, futuramente, seja feito um estudo mais detalhado sobre a CM mais adequada, já que, nesse sinal, o fato dos dedos estarem mais juntos ou afastados não parece ter relevância semântica no sinal, como ocorre com o sinal AGROTÓXICO, em que a base de formação é a mão aberta com os dedos afastados.

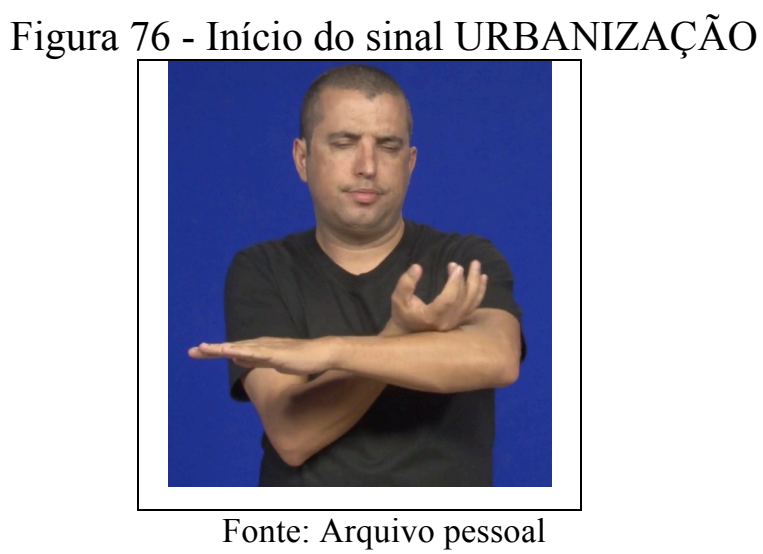

Outra dificuldade encontrada foi a escolha do ponto de articulação do sinal. Alguns sinais como NINHO e $\mathrm{CO}_{2}$ nos deixaram em dúvida se o ponto de articulação considerado seria o espaço neutro ou a outra mão. Em geral, os sinais realizados com duas mão ativas, tal qual RECICLAGEM e EROSÃO, que não estão bem demarcados em uma locação específica, são classificados como localizados no espaço neutro. Porém, se o local de sinalização for bem claro como no sinal FELINO, cujo sinal inicia-se no buço, a locação considerada é esta. Por outro lado, em sinais com uma mão dominante e a outra não dominante, a tendência é que esta última funcione como um PA, do mesmo modo como ocorre no sinal ÁREAS PROTEGIDAS, cujo dorso da mão não dominante serve de locação para a realização do sinal.

Os sinais $\mathrm{NINHO}$ e $\mathrm{CO}_{2}$ são sinais em condição de simetria, em que as duas mãos são iguais e os movimentos existentes em ambos são simultâneos. Contudo, na descrição dos 
parâmetros do primeiro sinal, consideramos como espaço neutro ${ }^{63}$ e no segundo, a ponta dos dedos. Isso porque no sinal NINHO fica a dúvida se o PA seria o dorso de uma mão ou a palma da outra mão, já que as duas mão se movimentam e se tocam ao mesmo tempo, e não há como estabelecer uma mão ativa e outra passiva. Então, para resolver o problema de descrição, consideramos como espaço neutro. Já no sinal $\mathrm{CO}_{2}$, tanto a mão direita quanto a esquerda têm como ponto de articulação a ponta do dedo da outra mão, por isso o PA ficou sendo a ponta dos dedos.

Ademais, encontramos sinais que possuem mais de um movimento simultâneo e para fazer a busca no GIMALP é preciso definir qual movimento vem primeiro, para então estabelecer a ordem dos movimentos. Desta feita, seguimos a organização de Barros (2015) proposta para a ELiS: o primeiro movimento considerado é o M de braços, depois o de dedos e punhos e por último os $\mathrm{M}$ sem mão. $\mathrm{O}$ sinal $\mathrm{CO}_{2}$, por exemplo, tem quatro movimentos simultâneos no início do sinal: movimento para cima (55), movimento para fora (62), tamborilar (78) e corrente de ar (88), porém, como no sistema podemos preencher até dois movimentos, os demais são desconsiderados.

\subsection{O suporte digital para o registro dos dados e a divulgação}

O suporte digital apresenta dois requisitos para o funcionamento do glossário: um diz respeito ao navegador e o outro à velocidade da internet. Para acessar a página do GIMALP, é preciso escolher como navegador o Google Chrome, ou o Firefox, ou o Internet Explore, ou o Safari ou o Opera. No caso, a conexão com a internet deve ser de $500 \mathrm{Kbps}$ ou mais. O glossário encontra-se disponível em http://glossariolibrasportugues.com.br.

\footnotetext{
${ }^{63} \mathrm{O}$ espaço neutro é uma região em frente ao corpo do sinalizante que abrange a região do pescoço até o tórax, como a demonstrada no quadro 21 , figura 33 , das locações.
} 
Figura 77 - Página inicial do GIMALP

\section{GLOSSARIO ILUSTRADO} DO MEIO AMBIENTE LIBRAS/ PORTUGUÉS

Apresentação Tutorial Busca- Sobre Contato
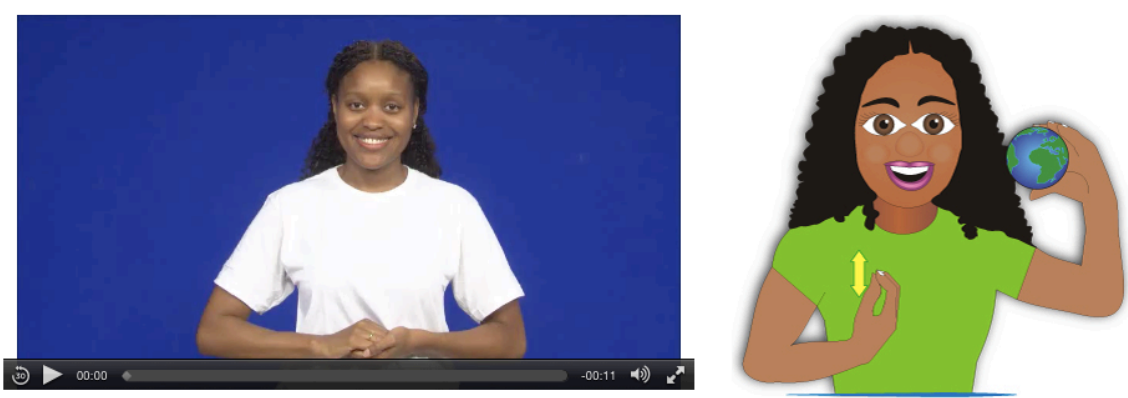

\section{Bem Vindo!}

Olá! Sejam bem vindos ao Glossário Ilustrado do Meio Ambiente Libras - Português! Este espaço foi construido para você que tem interesse e curiosidade em saber termos, definições e sinais referentes ao Meio Ambiente. Aqui você encontrará ilustrações, definições, vídeos e outros recursos que facilitarão a pesquisa. Por isso, sinta-se à vontade! Acesse, explore, divirta-se! Nesse Glossário, o conhecimento está sempre disponivel para você!

Fonte: Glossário Ilustrado do Meio Ambiente. Disponível em: <http://glossariolibrasportugues.com.br> Acesso em: 20 ago. 2016.

\subsubsection{Tipos de busca do glossário}

O GIMALP tem três mecanismos de busca pelo termo da área do Meio Ambiente que são: busca pela Língua de Sinais Brasileira, pela Língua Portuguesa e pelas ilustrações, conforme mostra a figura 78 .

Figura 78 - Mecanismos de busca do GIMALP

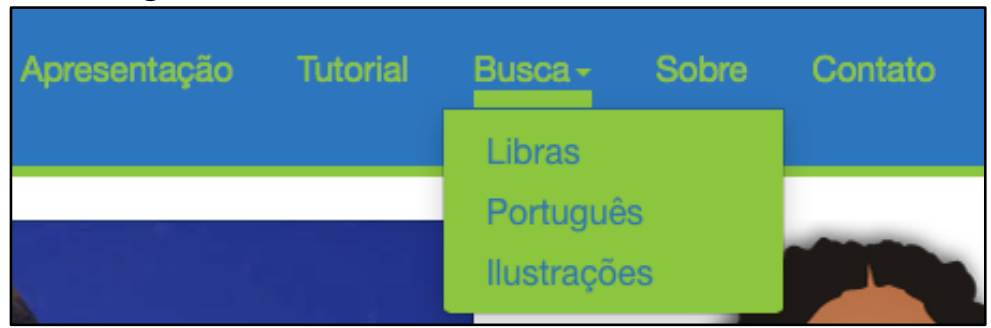

Fonte: Glossário Ilustrado do Meio Ambiente. Disponível em: <http://glossariolibrasportugues.com.br $>$ Acesso em: 20 ago. 2016.

A busca pela LSB é feita na aba "Busca" e escolhe-se a opção "Libras". Na busca pela Língua de Sinais, os consulentes podem ter acesso aos sinais-termo por meio dos parâmetros configuração de mão $(\mathrm{CM})$, movimento $(\mathrm{M})$ e locação $(\mathrm{PA})$. Essa busca é pelo início de determinado sinal que pode ser procurado por até duas CMs, até dois movimentos e um PA, todos referentes ao início do sinal. Todavia, é possível escolher apenas uma CM, ou um M, ou um PA, e o GIMALP dará as opções de sinais cadastrados com o(s) parâmetro(s) 
escolhido(s). As 75 CMs de Faria-Nascimento, os 44 movimentos e as 35 locações de Barros mostrados no início desse capítulo são ícones de busca que nos levam aos sinais.

Figura 79 - Mecanismo de busca pela LSB

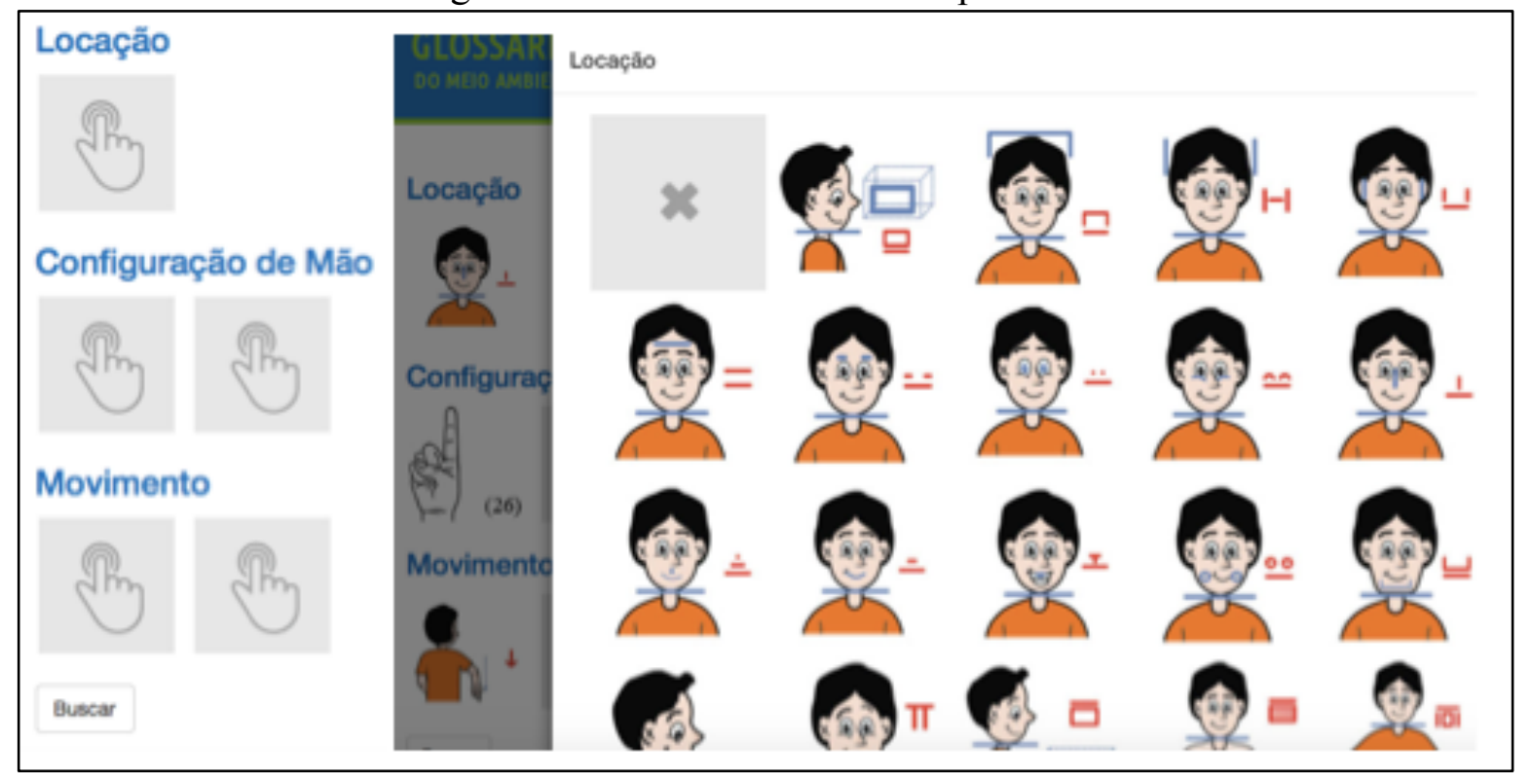

Fonte: Glossário Ilustrado do Meio Ambiente.

$<$ http://glossariolibrasportugues.com.br/verbete/sinal/> Acesso em: 22 ago. 2016.

A busca pela LP segue a tradicional ordem alfabética - clica-se na aba "Busca", escolhe-se a opção "Português" e seleciona-se a letra do termo em LP que se deseja encontrar.

Figura 80 - Mecanismo de busca pela LP

\begin{tabular}{|c|c|c|c|c|c|c|c|c|c|c|c|c|c|c|c|c|c|c|c|c|c|c|c|}
\hline * & A & B & $\mathrm{C}$ & D & $E$ & $F$ & G & $\mathrm{H}$ & 1 & $J$ & L & M & $\mathrm{N}$ & 0 & $P$ & Q & $R$ & $\mathrm{~s}$ & $\mathbf{T}$ & $u$ & v & $x$ & $z$ \\
\hline \multicolumn{24}{|c|}{ Entrada } \\
\hline \multicolumn{24}{|c|}{ ecologia } \\
\hline \multicolumn{24}{|c|}{ ecossistema } \\
\hline \multicolumn{24}{|c|}{ educaçăo ambiental } \\
\hline \multicolumn{24}{|c|}{ efeito estufa } \\
\hline \multicolumn{24}{|c|}{ erosão } \\
\hline \multicolumn{24}{|c|}{ espécie } \\
\hline extin & & & & & & & & & & & & & & & & & & & & & & & \\
\hline
\end{tabular}

Fonte: Glossário Ilustrado do Meio Ambiente. Disponível em:

$<$ http://glossariolibrasportugues.com.br/verbete/alfabeto/e> Acesso em: 20 ago. 2016. 
A busca pela ilustração é um mecanismo pensado para usufruir das habilidades visuais dos surdos na apreensão do mundo, além de oferecer uma opção a mais de busca quando o consulente não souber o sinal-termo ou o termo em LP, mas tenha uma noção visual do significado, ou simplesmente consultar por curiosidade a partir dos desenhos.

Para a busca pela ilustração, clica-se na aba "Busca", seleciona-se a opção "Ilustrações" e escolhe-se o desenho desejado, que possui um link, localizado na parte superior esquerda da ilustração, no qual levará a determinado termo, caso essa palavra buscada esteja cadastrada (figuras 81 e 82). É claro que essa busca pode ser desenvolvida e as ilustrações podem ser separadas por campos temáticos a fim de facilitar a busca. Para esta tese, postamos 150 ilustrações que podem ser conferidas rolando o cursor para baixo até a visualização de todos os desenhos cadastrados. Futuramente poderemos organizar a busca das ilustrações por subdivisões, tais como, os campos temáticos citados nos procedimentos metodológicos.

Figura 81 - Mecanismo de busca pelas ilustrações

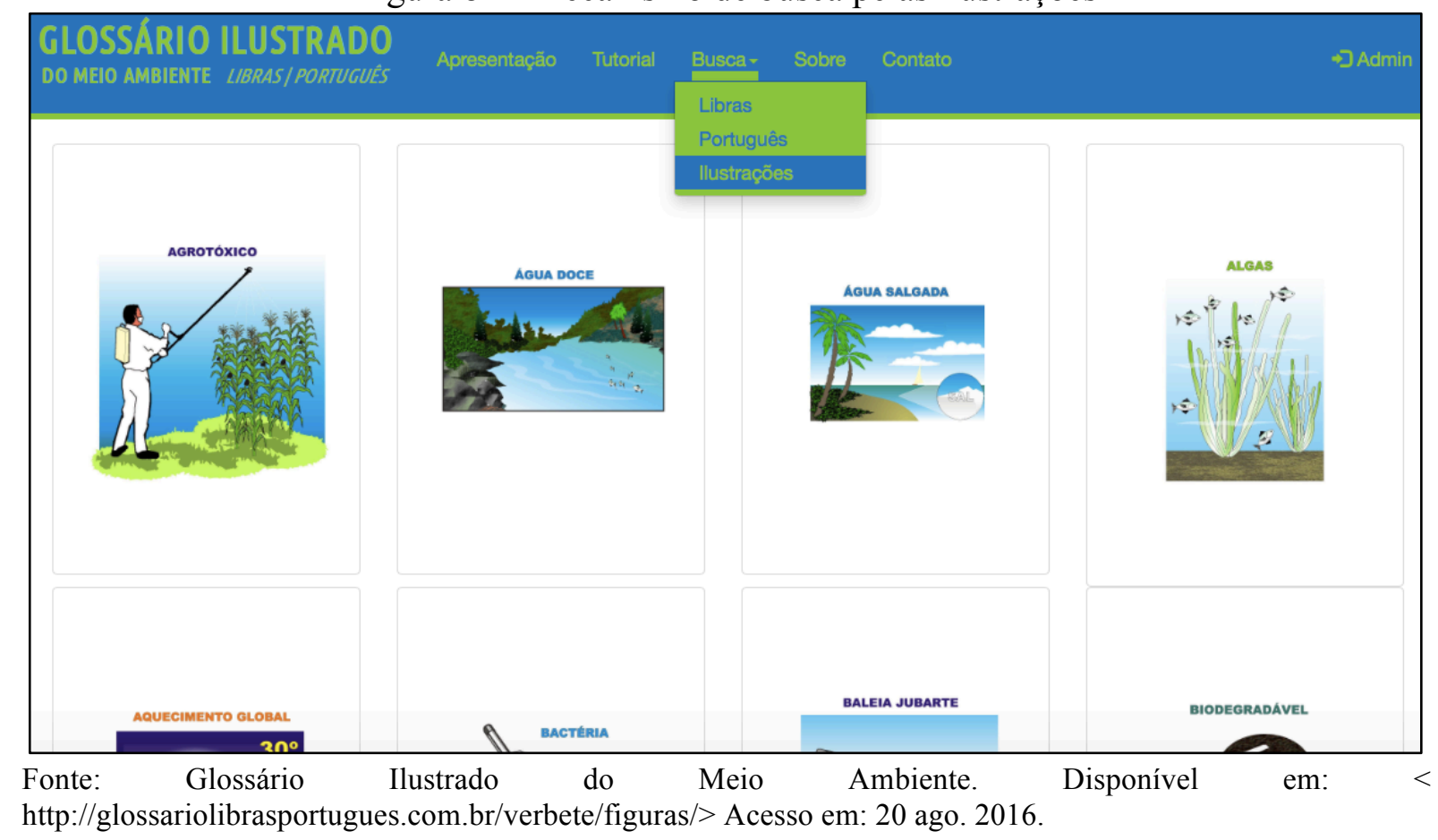


Figura 82 - Link de acesso ao verbete a partir da ilustração

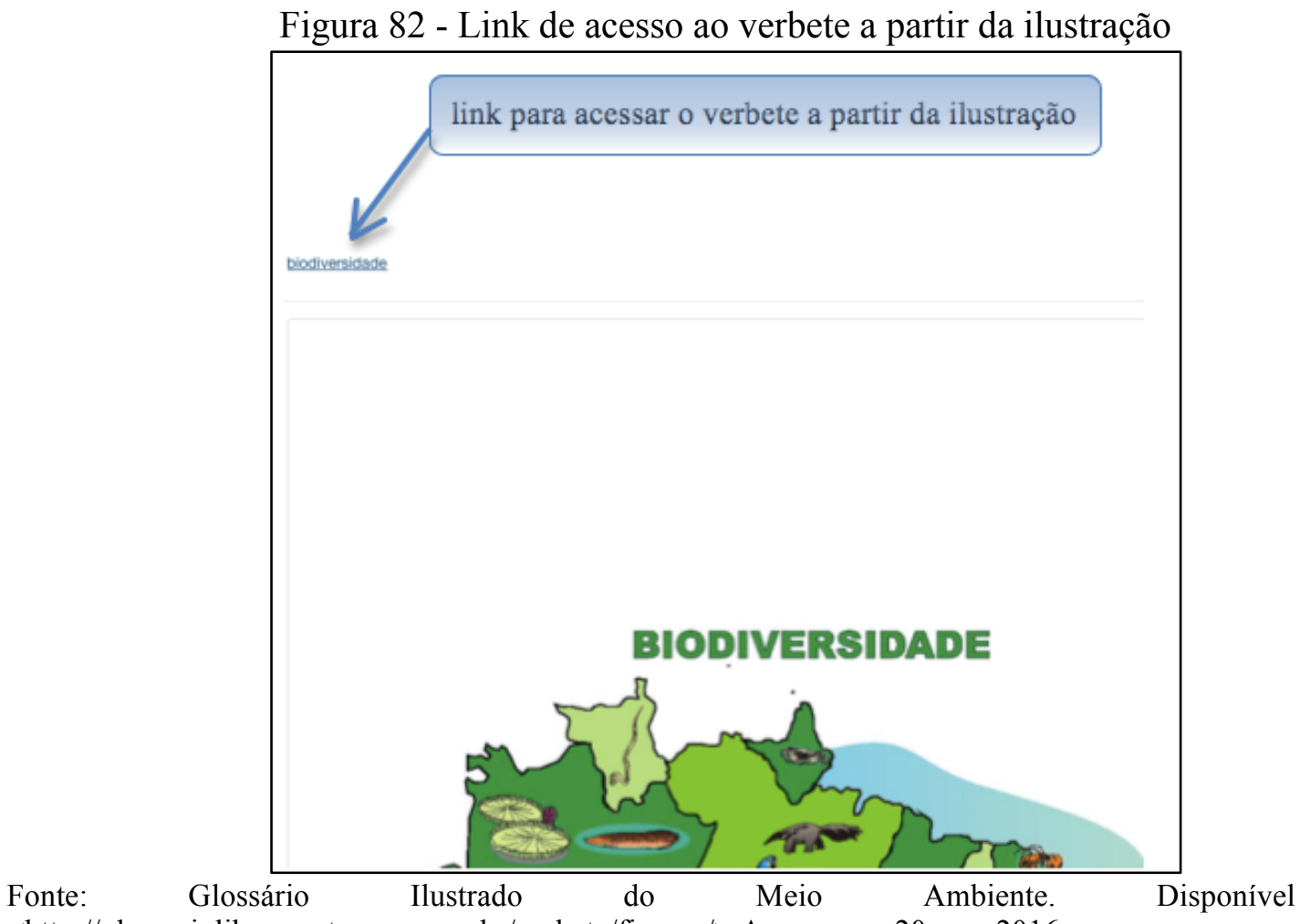

\subsubsection{O modelo do verbete}

O verbete do GIMALP é composto por informações em LSB, LP e uma ilustração. As informações do verbete disponíveis em LSB podem ser sistematizadas da seguinte forma:

$$
+ \text { entrada } \pm \text { variante } \pm \text { plural }
$$

A entrada em LSB é o sinal-termo, obrigatório no verbete, e no GIMALP aparece nomeado de "Sinal". Já a variante e o plural em LSB são opcionais, ou seja, só se houver. Acrescentamos a opção chamada de "plural" na parte do verbete da LSB, porque o plural nessa língua se apresenta de diversas formas, como mostrado no capítulo 4 na análise dos sinais-termo. 
Figura 83 - Parte do verbete em LSB

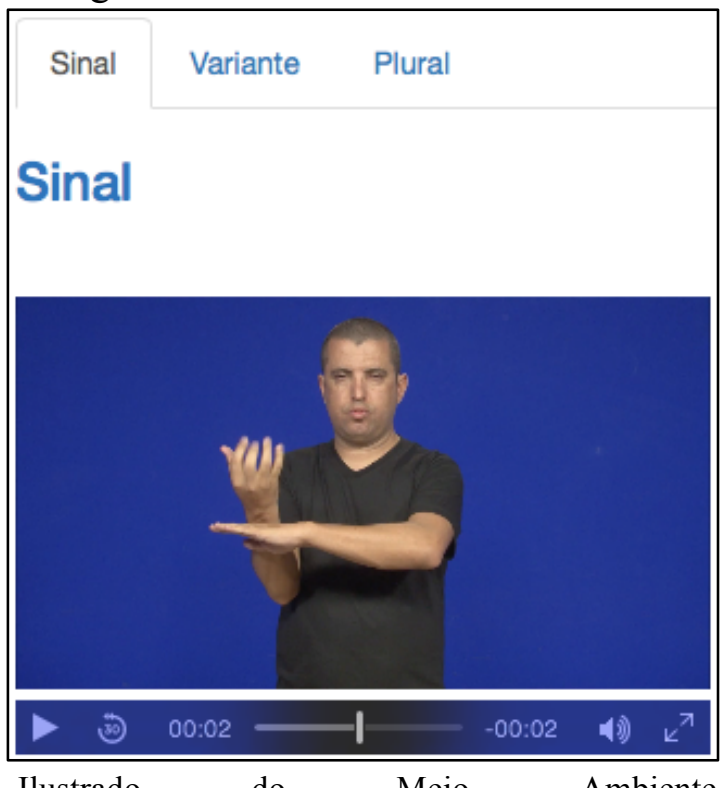

Fonte: Glossário

em:

$<$ http://glossariolibrasportugues.com.br/verbete/55> Acesso em: 20 ago. 2016.

A parte do verbete em LP é composta dos seguintes elementos obrigatórios: entrada, informação gramatical - composta de categoria e gênero -, definição e fonte da definição e dos elementos opcionais (se houver): variantes e remissivas. Apresentamos a parte do verbete em LP. Antes, arrolamos as abreviações referentes à sua composição: s. = substantivo; f. = feminino; $\mathrm{AD}=$ Aulete Digital; DIMA $=$ Dicionário Ilustrado de Meio Ambiente; adapt. $=$ adaptado por; $\mathrm{CBN}=$ Cristiane Batista do Nascimento; Var. = variante e $\mathrm{V}$. = ver remissiva.

Figura 84 - Informações do verbete em LP

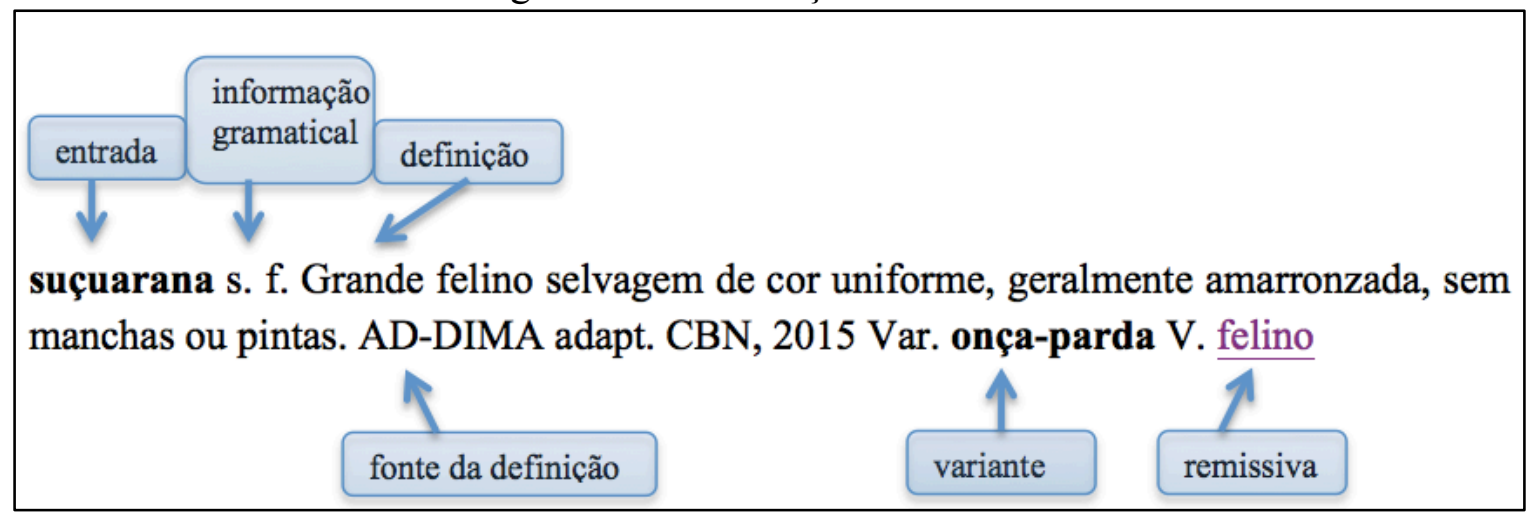

Fonte: Elaborada pela autora 
Figura 85 - Modelo de verbete do GIMALP

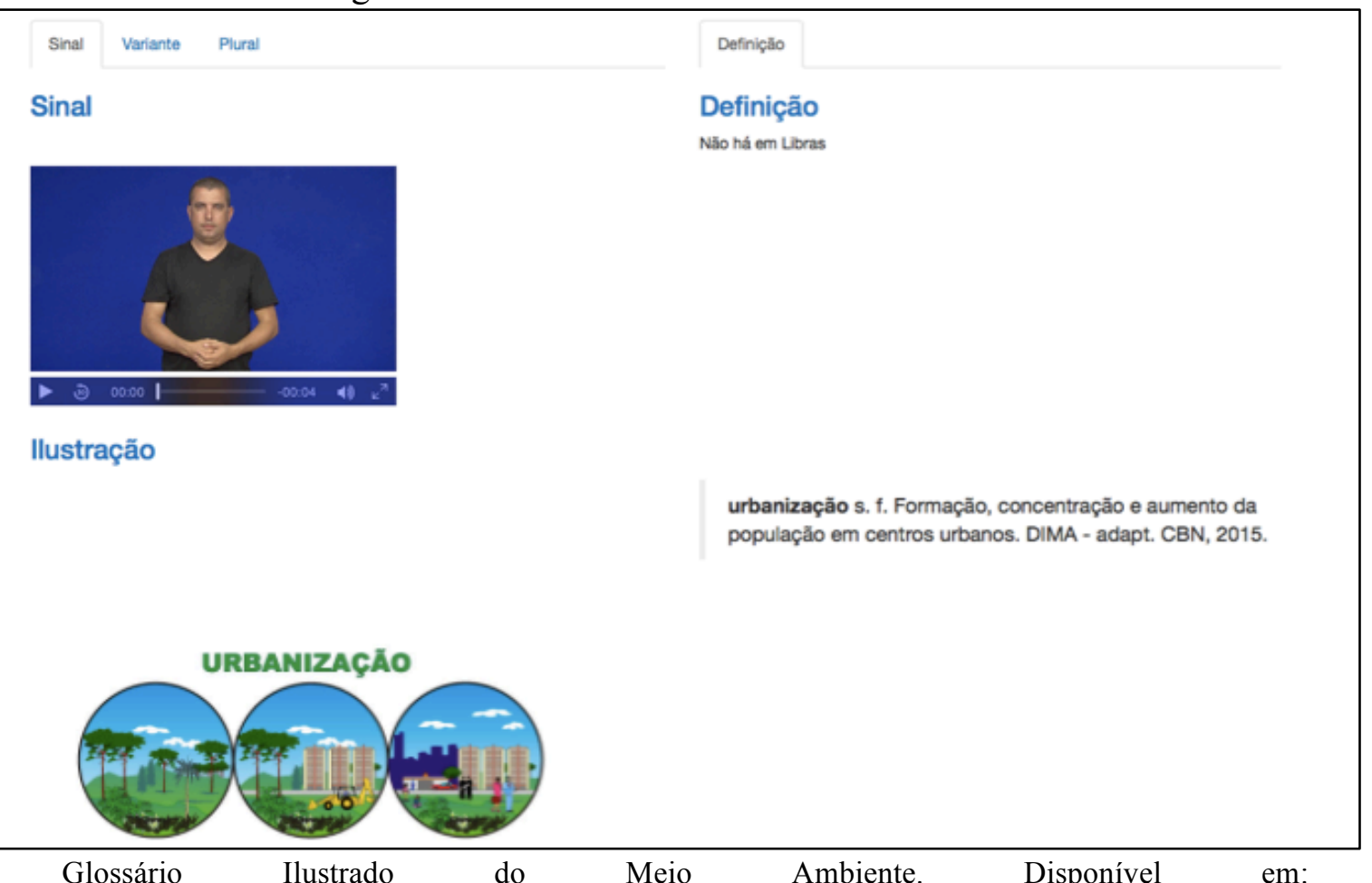

Fonte:

Glossário

Ilustrado

Meio

Ambiente.

Disponível

em:

$<$ http://glossariolibrasportugues.com.br/verbete/67> Acesso em: 20 ago. 2016.

\subsubsection{Registro dos dados}

O suporte digital do GIMALP possui uma aba denominada Admin na qual podem ser cadastrados os verbetes, as variantes, as ilustrações e a configuração. Esta última aba é destinada à escrita e a postagem dos vídeos de boas-vindas, à apresentação e ao tutorial. Ao clicar em Admin, aparece a aba que está representada na figura 86. Cabe aqui esclarecer que o acesso à Admin é restrito ao administrador do GIMALP.

Figura 86 - Aba Admin do GIMALP

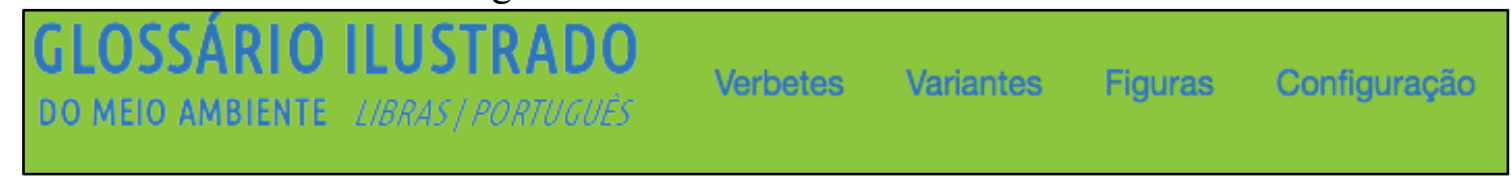

Fonte: Glossário Ilustrado do Meio Ambiente. Disponível em:

$<$ http://glossariolibrasportugues.com.br/admin/verbete/> Acesso em: 20 ago. 2016.

Ao cadastrar um verbete, clica-se em "Verbetes" e, em seguida "Novo", onde aparecem as opções de preenchimento de um novo verbete. As opções de preenchimento da parte do verbete em LP são: entrada, onde se cadastra o termo do verbete em LP; categoria, deve-se escolher adj. para adjetivo, s. para substantivo ou v. para verbo; gênero, escolhe-se m. 
para masculino, f. para feminino ou $2 \mathrm{~g}$. para comum de dois gêneros; as remissivas, local onde aparecem todas as entradas cadastradas; a definição e a fonte da definição. Todos esses elementos são de preenchimento obrigatório. A única exceção é a escolha de remissivas, essa parte é opcional.

Para cadastrar o início de cada sinal-termo, existem as opções mão 1, mão 2, movimento 1, movimento 2, articulação (PA) e a figura, que é o espaço para associar uma imagem previamente cadastrada com o termo a que se refere. Os elementos de preenchimento obrigatório são mão 1 e articulação (PA), já a mão 2, os movimentos e a figura são opcionais.

Há também espaço para postar quatro vídeos - o único obrigatório é o espaço denominado "Vídeo sinal", destinado ao cadastro do sinal-termo. O espaço para postar o vídeo com a variante da LSB, caso exista, é denominado "Vídeo variante" e espaço para cadastrar o plural de determinado sinal-termo, também, se houver, é denominado "Vídeo plural". O espaço "Vídeo definição" é o lugar que mostra a definição em vídeo do termo em LSB, porém, o GIMALP é semibilíngue e não preencherá esse espaço. Por fim, o botão "Salvar" serve para gravar as informações cadastradas.

Figura 87 - Ficha de cadastro de verbete

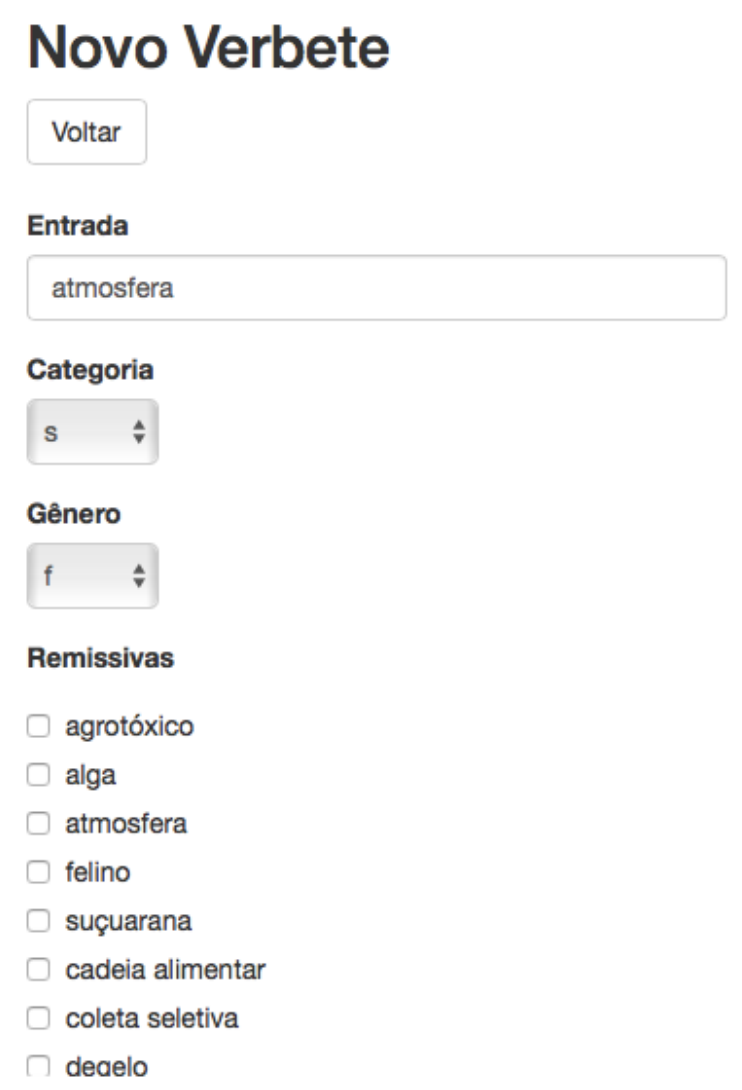


Definição

Camada de gases, fina, sem cheiro, sem cor, sem
sabor, presa à Terra.
Fonte da Definição
VIBGE adapt. CBN, 2015.

Mão1:

mao15
Mão2:
Movimento 1
movimento59

\section{Movimento 2}

movimento78 ง

\section{Articulaçao}

Figura

atmosfera

Vídeo Sinal
Selecionar Arquivo atmosfera.mp4
Vídeo Variante
Selecionar Arquivo nenhum arquivo selecionado
Vídeo Plural
Selecionar Arquivo nenhum arquivo selecionado
Vídeo Definição
Selecionar Arquivo nenhum arquivo selecionado
Salvar

Fonte: Glossário Ilustrado do Meio Ambiente. Disponível em: $<$ http://glossariolibrasportugues.com.br/admin/verbete/novo/> Acesso em: 20 ago. 2016.

Para incluir a(s) Variante(s) da Língua Portuguesa, cadastra-se um novo termo na entrada - essa nova palavra é a variante que é associada a um verbete já existente como demonstrado na figura 88, em que o verbete floresta já existe. Além disso, é preciso indicar a categoria e o gênero da variante cadastrada. 
Figura 88 - Espaço para cadastrar a(s) variante(s) em LP

\section{Nova Variante}

\section{Entrada}

$$
\text { mata }
$$

\section{Categoria}

$$
\text { s }
$$

Gênero

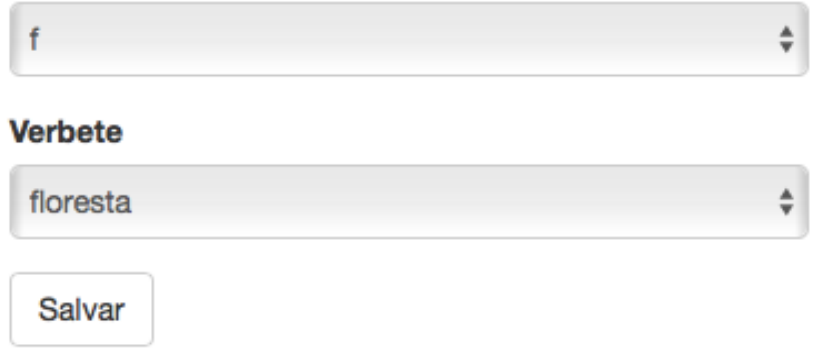

Fonte: Glossário Ilustrado do Meio Ambiente. Disponível em: $<$ http://glossariolibrasportugues.com.br/admin/variante_novo > Acesso em: 20 ago. 2016.

Para cadastrar uma ilustração, o documento com a imagem precisa estar em formato jpg. Há um espaço denominado "Descrição" onde se coloca o nome da figura e seleciona-se a imagem correspondente à descrição. Por último, clica-se no botão salvar.

Figura 89 - Espaço para cadastrar ilustrações

\section{Nova Figura}

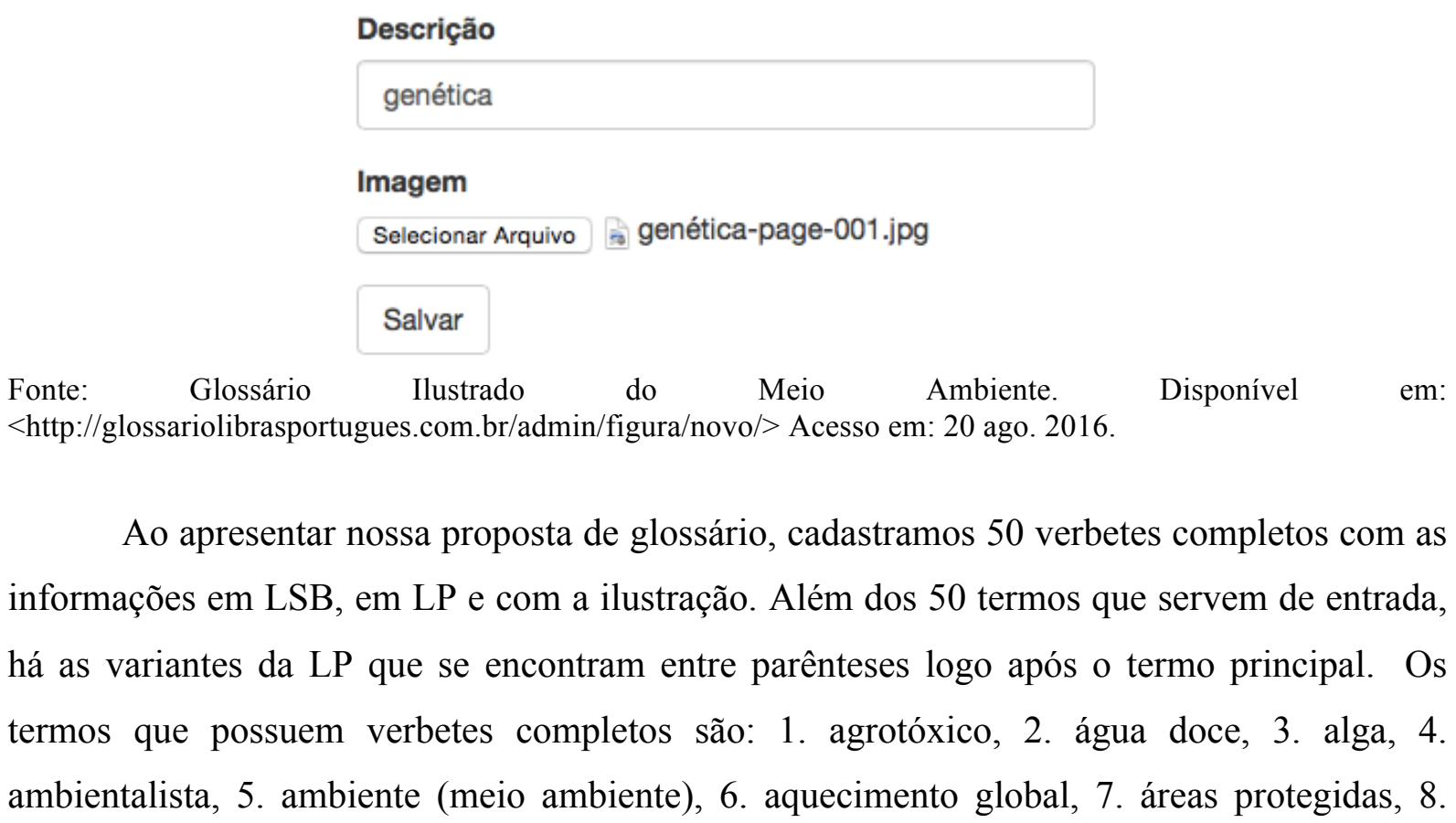


atmosfera, 9. biodiversidade (diversidade biológica), 10. bioma, 11. cadeia alimentar (cadeia trófica), 12. catador de lixo, 13. $\mathrm{CO}_{2}$ (dióxido de carbono e gás carbônico), 14. coleta seletiva, 15. combustível fóssil, 16. conservação, 17. degelo, 18. deslizamento de terra, 19. desmatamento (desflorestamento), 20. ecologia, 21. ecossistema, 22. educação ambiental, 23. efeito estufa, 24. erosão, 25. espécie, 26. extinção, 27. felino, 28. floresta (mata), 29. floresta tropical, 30. furacão (ciclone, tornado e tufão), 31. gelo, 32. habitat, 33. hidrosfera (talassosfera), 34. impacto ambiental, 35. inundação, 36. lavoura, 37. muda, 38. natureza, 39. ninho, 40. papel reciclado, 41. população, 42. predador, 43. preservação, 44. protocolo de kyoto, 45. queimada, 46. reciclagem, 47. suçuarana (onça-parda), 48. sustentabilidade, 49. tráfico de animais e 50. urbanização.

$\mathrm{Na}$ próxima seção, mostramos como usar o GIMALP, apresentando alguns desses sinais cadastrados.

\subsection{Como usar o glossário}

Por tratar-se de uma tese, não há introdução e prefácio, todavia, na plataforma online há um espaço destinado a essas informações que é a aba "Apresentação". Além disso, o GIMALP tem as abas "Tutorial" - destinada a explicar como usar o glossário -, "Sobre" onde constará o nome dos participantes, consultores e profissionais que contribuíram com o glossário - e "Contato" - que é espaço para enviar críticas e sugestões.

A seguir, apresentamos um quadro com as abreviações usadas no glossário. É válido ressaltar que os ícones das CMs, M e PA apresentados na subseção 5.2.1 são de fundamental importância para o uso do glossário no que diz respeito à busca pela LSB.

Quadro 21 - Abreviações do GIMALP

\begin{tabular}{|l|l|}
\hline Abreviação & \multicolumn{1}{|c|}{ Significado } \\
\hline adapt. & adaptado \\
\hline AD & Aulete Digital \\
\hline adj. & adjetivo \\
\hline CBN & Cristiane Batista do Nascimento \\
\hline 2g. & comum de dois gêneros \\
\hline DH & Dicionário Houaiss \\
\hline DIMA & Dicionário Ilustrado de Meio Ambiente \\
\hline f. & feminino \\
\hline GBNDES & $\begin{array}{l}\text { Glossário de termos usados em atividades agropecuárias, florestais e ciências } \\
\text { ambientais }\end{array}$ \\
\hline m. & masculino \\
\hline s. & substantivo \\
\hline
\end{tabular}




\begin{tabular}{|l|l|}
\hline V. & ver remissiva \\
\hline VAI & Vocabulário Ambiental Infantojuvenil \\
\hline VIBGE & $\begin{array}{l}\text { Vocabulário Básico de Recursos Naturais e Meio Ambiente do Instituto } \\
\text { Brasileiro de Geografia e Estatística }\end{array}$ \\
\hline Var. & variante \\
\hline
\end{tabular}

Fonte: Elaborado pela autora

O consulente do GIMALP, como apresentamos na subseção 5.4.1, tem três mecanismos de busca: pela LSB, pela LP e pela ilustração. Neste momento, faz-se necessário uma explicação mais detalhada do sistema de busca pela LSB.

Para a busca em LSB, o usuário tem três opções:

1) preencher apenas um quadrado, por exemplo, a locação.

2) preencher parcialmente os quadrados, por exemplo, uma configuração de mão e um movimento.

3) preencher todos os quadrados, a locação, as duas configurações de mão e os dois movimentos.

Convém, neste momento, esclarecer que a busca pelo sinal pode ser iniciada por qualquer um dos três parâmetros, PA, CM ou M. Se o consulente souber apenas o movimento, pode iniciar a busca por este parâmetro. Da mesma forma, se souber apenas o ponto de articulação ou só uma configuração de mão, pode iniciar a busca por um destes outros parâmetros, desde que seja um parâmetro do início do sinal buscado.

Demostramos a seguir, a busca pelo sinal-termo EROSÃO. Caso o consulente conheça parcialmente o início do sinal, pode selecionar as informações referentes aos parâmetros constitutivos do sinal e, dessa forma, diminuir as opções de entrada para encontrar o sinal desejado, como pode ser visto na figura 90.

Nessa figura, mostramos que, quanto mais informações se conhece a respeito do sinal, mais fácil se chega ao sinal-termo desejado. No primeiro quadro da figura, selecionamos o ponto de articulação "espaço neutro". Os sinais-termo que são constituídos por esse PA são: BIOMA, COMBUSTÍVEL FÓSSIL, EROSÃO, INUNDAÇÃO, NINHO, PAPEL RECICLADO, PREDADOR, RECICLAGEM, EXTINÇÃO e ECOSSISTEMA. No segundo quadro, com a inserção de mais uma informação do sinal, no caso a CM número 51, as possibilidades diminuem para os seguintes sinais: BIOMA, EROSÃO e ECOSSISTEMA. No terceiro quadro, ao inserir o movimento, já aparece uma única entrada que é o sinal EROSÃO. No quarto quadro, caso ainda tivesse mais possibilidades de entrada, poderíamos restringir mais as opções de entrada colocando todas as informações referentes ao início desse sinaltermo. 
Figura 90 - Como usar o GIMALP restringindo as opções de entrada

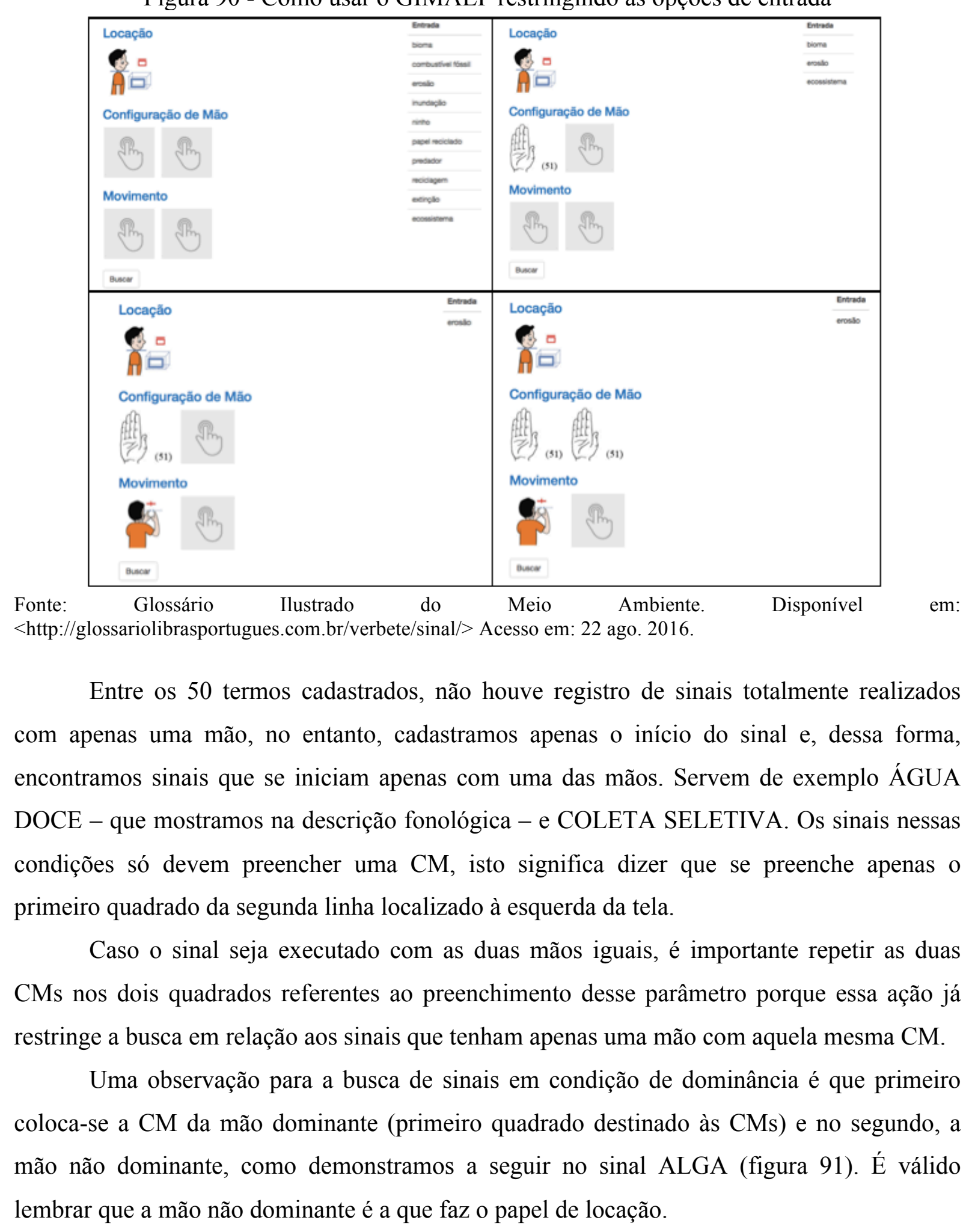


Figura 91 - Busca por sinal em condição de dominância e início do sinal ALGA

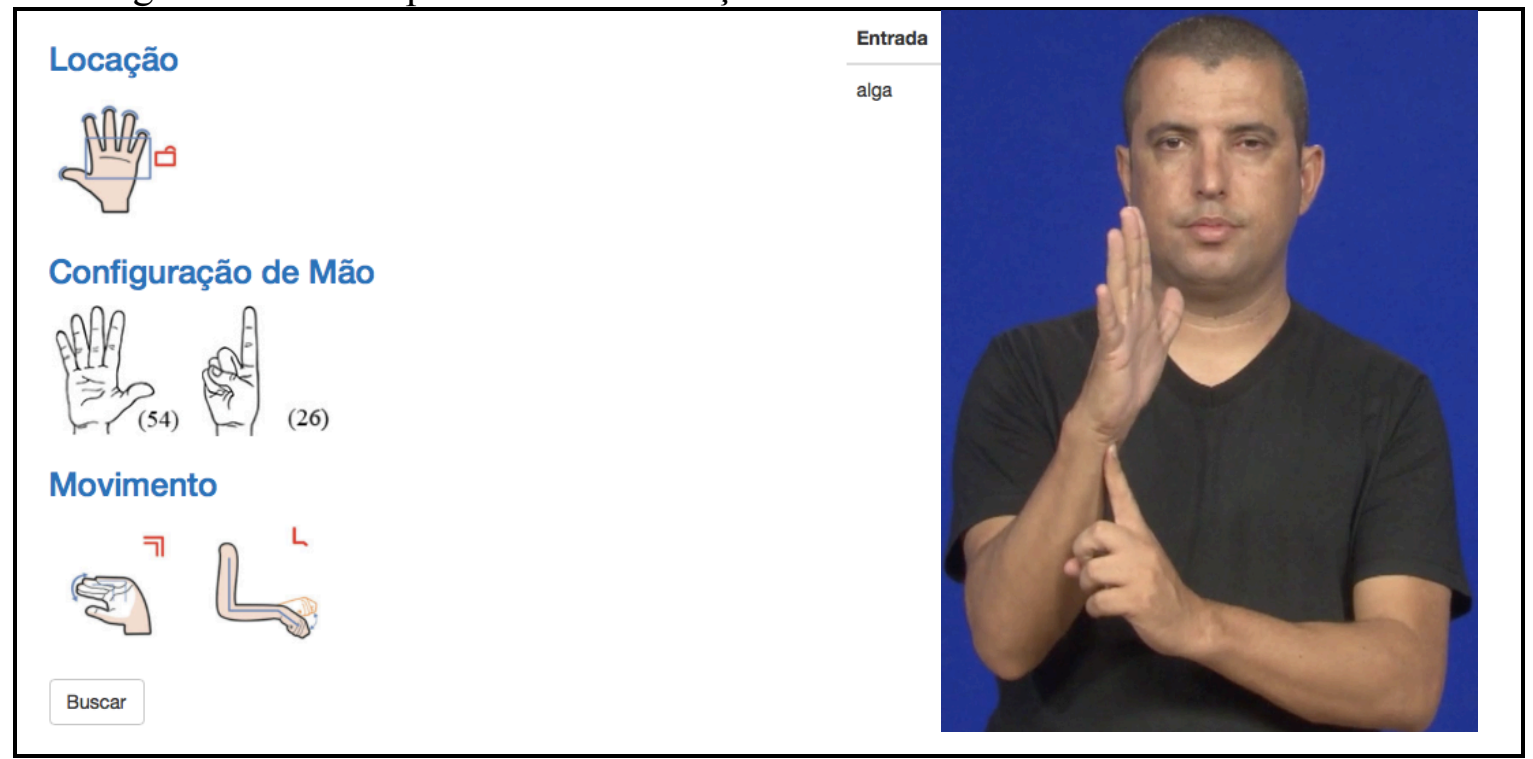

Fonte: Elaborada pela autora

Apresentamos na figura 92, o preenchimento de como buscar sinais que violam as condições de simetria e de dominância. Apesar de serem tipos de sinais atípicos em LSB, é preciso esclarecer como buscar sinais com essas características incomuns. Serve de exemplo, o sinal PAPEL RECICLADO, que é executado com as duas mãos ativas, todavia, as CMs são diferentes. Sinais nessa situação são pesquisados como os sinais em condição de dominância, a mão direita é a mão que ocupará o primeiro quadrado e a mão esquerda, o segundo quadrado. Para selecionar a CM desejada, é preciso ter em mente que essa escolha deve ocorrer a partir da perspectiva do consulente destro.

Figura 92 - Busca de sinal que viola as condições de simetria e de dominância

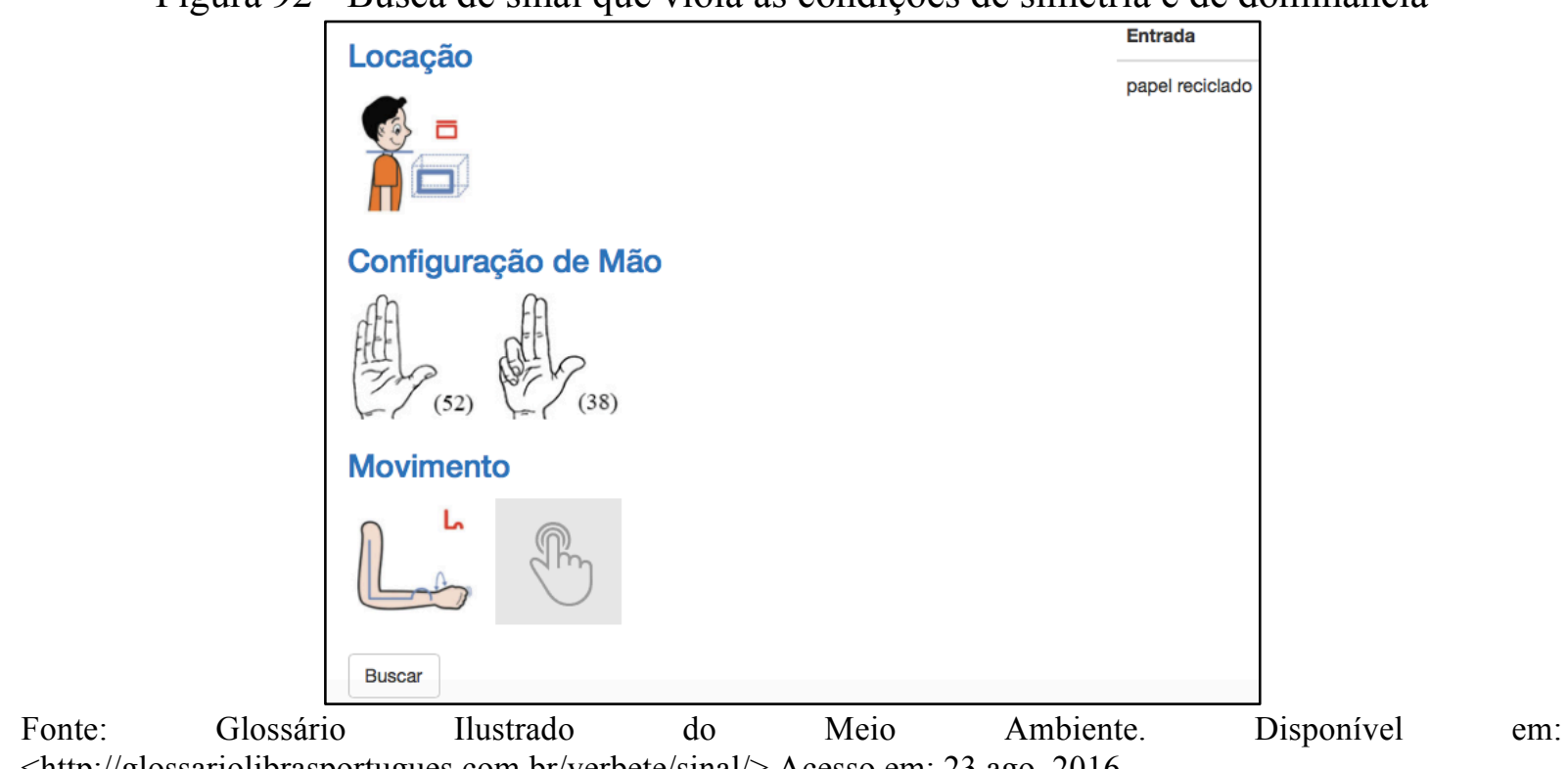

$<$ http://glossariolibrasportugues.com.br/verbete/sinal/> Acesso em: 23 ago. 2016. 
Uma orientação importante para todos os tipos de sinais com mais de um movimento simultaneamente é que devem seguir a ordem proposta por Barros (2015). A sequência estabelecida por ela é: primeiro o movimento de braços, segundo, o movimento de dedos e punho, e terceiro, o movimento sem as mãos. Isso significa dizer que, caso não haja movimento de braço, o primeiro é o movimento de dedos, depois o movimento de punho, em seguida de antebraço e, por último, o movimento sem as mãos.

Conforme explicamos nessa seção, a busca pelo sinal pode ser iniciada por qualquer um dos três parâmetros (CM, M e PA). Contudo, fizemos alguns testes no glossário e chegamos a conclusão de que iniciar a busca pela locação pode levar o consulente mais rápido ao sinal desejado. Em virtude desses testes, posicionamos a locação como o primeiro parâmetro a ser preenchido no mecanismo de busca pela LSB. Isso porque nos testes realizados, com exceção do ponto de articulação "espaço neutro", os sinais buscados nas sequências $1^{\circ} \mathrm{PA}, 2^{\circ} \mathrm{CM}$ e $3^{\circ} \mathrm{M}$ ou $1^{\circ} \mathrm{PA}, 2^{\circ} \mathrm{M}$ e $3^{\circ} \mathrm{CM}$, são encontrados mais rapidamente no glossário, e, por diversas vezes, com menos informações sobre os parâmetros iniciais do sinal, quando comparadas com as sequências $1^{\circ} \mathrm{CM}, 2^{\circ} \mathrm{M}$ e $3^{\circ} \mathrm{PA}$ ou $1^{\circ} \mathrm{M}, 2^{\circ} \mathrm{CM}$ e $3^{\circ} \mathrm{PA}$. Porém, é preciso alimentar mais o glossário e realizar novos testes para confirmar se de fato iniciar pelo parâmetro locação - PA - pode ser um atalho para se chegar mais rápido ao sinal desejado.

É válido explicitar ainda algumas funcionalidades do GIMALP, por exemplo, caso não haja nenhum sinal correspondente para a busca feita pelo usuário, aparece a mensagem "nenhum verbete encontrado". Além disso, a ilustração pode ser ampliada tanto no verbete completo quanto na busca pela ilustração. Ademais, os vídeos com o sinal-termo, com a variante e com o plural podem ser ampliados na tela.

\subsection{Síntese do capítulo}

Neste capítulo, apresentamos a proposta do GIMALP e suas características intrinsecamente relacionadas ao público-alvo. Além disso, apresentamos as soluções encontradas para auxiliar o público-alvo em suas dificuldades com a LP no glossário. Também, mostramos os problemas de descrição fonológica para a busca pelo sinal, o suporte digital em que o GIMALP está abrigado, os tipos de busca, o modelo do verbete, como os dados são registrados e como consultar o glossário online, principalmente no que diz respeito à busca pela Língua de Sinais Brasileira. 


\section{CONSIDERAÇÕES FINAIS}

Desenvolvemos uma pesquisa de doutoramento com vista a oferecer subsídios educacionais para estudantes Surdos do Ensino Fundamental II, do $6^{\circ}$ ao $9^{\circ}$ ano, na faixa etária entre 11 e 14 anos. A proposta foi guiada por três pontos essenciais que envolvem a educação de pessoas surdas no Brasil, a saber: a Língua de Sinais Brasileira (LSB ou Libras), a Língua Portuguesa como Segunda Língua e a visualidade dos surdos.

A partir desse perfil, nos debruçamos a criar uma obra terminológica com características que pudessem atender melhor às singularidades linguísticas do público em questão.

Para tanto, propomos um novo modelo de Glossário que apresenta como mecanismos de busca, além da tradicional ordem alfabética, a LSB pelos três principais parâmetros, a saber: configuração de mão (CM), locação (PA) e movimento (M). Esse tipo de busca é uma inovação para lexicografia especializada da língua de sinais brasileira, tendo em vista que as obras existentes, até o momento, apresentam a busca por até dois parâmetros, a CM e o PA. Dito de outro modo, a busca pelo movimento em conjunto com a CM e o PA é uma ferramenta nova para a pesquisa da LSB, uma vez que não identificamos em nenhuma outra obra essas características.

Ainda como diferencial de nossa proposta, apresentamos a busca por intermédio de ilustrações. Acrescentamos que os desenhos foram todos criados para esta obra lexicográfica a partir de discussões com especialistas e validação por um surdo biólogo.

A possibilidade de busca diferenciada foi inspirada, principalmente, na realidade de defasagem na aquisição da linguagem do público que, por vezes, não têm palavras em nenhuma das línguas, nem em língua de sinais e, muito menos em uma língua oral, tem apenas uma imagem mental do que seria determinado referente. Acreditamos que esse pode ser um caminho para a Lexicografia e para a Terminografia das LS. É necessário esclarecer, por sua vez, que as ilustrações precisam ser organizadas em campos temáticos para que o sistema de busca pela ilustração se torne mais efetivo.

Uma das grandes críticas à lexicografia de língua de sinais é a forma como os sinais são representados por meio de ilustrações. Essas imagens com o apoio de setas e outros símbolos não dão a clareza necessária para se compreender a correta execução dos sinais. Esse foi um dos motivos pelo qual decidimos pela mídia eletrônica, que além de resolver diversos problemas relacionados ao tipo de suporte do dicionário, apresenta inúmeras 
ferramentas tecnológicas que podem ser implementadas, entre elas, o uso de vídeos, tanto para o registro dos sinais da língua quanto para a explicação de como usar o dicionário.

Em relação à parte do verbete em LP, algumas medidas foram tomadas, a fim de manter a sistematicidade do glossário. Primeiramente, seguimos as orientações de Faulstich (2010 e 2011) para a criação de obras lexicográficas e terminográficas. Em seguida, criamos um método para a reformulação da definição terminológica com base nas categorias verbais SER incl, SER qual, POSSUIR, FAZER, SERVIR para e RESULTAR de - postuladas por Finatto (2001). Esse método contribuiu de forma substancial para a seleção dos conceitos mais relevantes do termo e para reduzir a extensão do texto definitório em relação ao texto original. Além disso, sempre que possível o vocabulário original das definições foi substituído por palavras e frases mais correntes da Língua Portuguesa.

Após pesquisar materiais diversos para criar o GIMALP, constatamos que a terminologia do Meio Ambiente em LSB era escassa. No intuito de contribuir com a expansão terminológica e "equipar" a LSB, apropriando-nos aqui do termo de Calvet (2007), promovemos sessões de criação e de validação dos sinais. Nessas sessões foram criados sinais conceituais que, por serem transparentes semanticamente, muitas vezes, dispensam definição, pois o próprio sinal contribuiu para o entendimento conceitual, e assumiram a função de sinaltermo. Os sinais-termo são propostas terminológicas e reconhecemos que alguns sinais ainda precisam se acomodar à LSB e serem aperfeiçoados, apesar de que, na análise preliminar dos mecanismos de criação dos sinais-termo, identificamos poucos sinais que violam as restrições de condição de simetria e de dominância. Por outro lado, os participantes das sessões de validação criticaram a extensão de alguns sinais, que foram considerados demasiadamente extensos, e, em vista disso, fica clara a necessidade de uma nova validação para o aperfeiçoamento dos sinais-termo.

Ainda em relação à análise dos mecanismos de criação, concluímos que os parâmetros constitutivos do sinal: CM, Or, PA, M e ENM, juntamente com os mecanismos de formação de sinais por composição, por meio de metonímias, empréstimos, entre outros, mostraram-se bastante produtivos e, portanto, a terminologia da Língua de Sinais Brasileira pode ser expandida até onde o conhecimento for acessível à pessoa Surda. O ponto de partida para equipar a LSB com terminologia é permitir aos surdos o acesso às informações em um nível cada vez mais especializado. E esta acessibilidade, por meio da LSB, os permite ser autônomos na busca de seu próprio conhecimento e conquistar espaço em níveis acadêmicos cada vez mais especializados. 
É preciso equipar a LSB com terminologia para que cumpra sua missão de ser uma língua escolar, na qual o estudante surdo possa aprender em sua própria língua, o que, sem sombra de dúvida, favorece o aprendizado de conteúdos e da LP.

Uma obra lexicográfica é um trabalho de equipe e repleto de detalhes, como vemos a seguir, por isso, há vários itens que gostaríamos de ter inserido na plataforma online, porém, não foi possível para momento. Arrolamos, a seguir, algumas ferramentas que desejaríamos ter no GIMALP: controle de velocidade dos vídeos com os sinais-termo, outra busca pela LP, porém feita por meio da digitação da palavra desejada parcial ou completamente, possibilidade de o consulente fazer o download dos vídeos e das outras informações contidas no verbete e as ilustrações estarem disponíveis para a busca a partir de campos temáticos.

Em relação ao conteúdo, gostaríamos de contar com equipes de criação e de validação com mais participantes surdos proficientes em LSB, entre eles, especialistas e não especialistas. Além disso, fazer uma validação das ilustrações com um grupo de surdos. Também inserir a escrita de sinais (ELiS), como mais uma possibilidade de expressão em língua de sinais.

Para finalizar, retomamos a pergunta que norteou nosso estudo e sistematizamos nossas ações e decisões em tópicos. O questionamento do início de nossa pesquisa foi: Que características da macro e da microestrutura de uma obra lexicográfica semibilíngue contribuem para atender as especificidades dos surdos?

Em relação à macroestrutura podemos destacar:

i) 150 Ilustrações criadas a partir de discussões com os especialistas da área e revisadas por um especialista surdo.

ii) Tipos de busca, além da tradicional busca pela ordem alfabética, com outras duas possibilidades, pelos três principais parâmetros da LSB: CM, PA e M e; busca pela ilustração.

iii) Ícones de busca pela LSB com imagens de fácil associação com o parâmetro a ser buscado.

Em relação à microestrutura do verbete podemos destacar:

i) Sinais-termo conceituais e transparentes;

ii) Uso da linguagem comum da LP para dar conta de parte do conteúdo especializado, sempre que possível;

iii) Definições reformuladas e não apenas a compilação de obras já existentes sem uma adaptação para o público-alvo; 
iv) Estratégia de usar, sempre que possível, o tipo na definição para auxiliar no estabelecimento de referências com o mundo real.

Por fim, convém lembrar que, por se tratar de uma proposta, o GIMALP possui apenas 50 sinais-termo cadastrados. Concluímos que o glossário também contribui com análises linguísticas dos sinais, principalmente na análise dos principais parâmetros constitutivos desse itens lexicais; ademais a ferramenta é útil para ensinar a LSB como primeira língua, a partir da conscientização dos sinalizantes sobre sua própria língua. Acima de tudo, porém, pretendemos contribuir com as reivindicações da comunidade Surda no que diz respeito às suas singularidades linguísticas, de ter a LP escrita como segunda língua e aos seus direitos de aprender e ensinar em Língua de Sinais. 


\section{REFERÊNCIAS}

ALMEIDA, M. N. S; ROMANHOL, T. A. S. Consciência ambiental do surdo universitário. Disponível em:

$<$ http://editora-araraazul.com.br/portal/images/revista/edi\%C3\%A7\%C3\%A3o13/artigos/1\%C2\%BA\%20Artigo\% 20da\%20REVISTA\%2013\%20[Almeida\%20\&\%20Romanhol].pdf $>$. Acesso em: 9 set. 2014.

AMARAL, W. M. Sistema de transcrição da língua brasileira de sinais voltado à produção de conteúdo sinalizado por avatares 3D. Campinas, SP: [s.n.]. Tese (Doutorado) - Faculdade de Engenharia Elétrica e de Computação, Universidade Estadual de Campinas, 2012.

AGUIAR, T. C. Nova proposta de sílaba em Libras. 2013. 99 f. Dissertação (mestrado) Universidade Federal de Goiás, Pós-Graduação em Letras e Linguística.

ALVES, I. M. Neologismo: criação lexical. - 3. ed. - São Paulo: Ática, 2007.

. Questões epistemológicas e metodológicas em terminologia, In: Anais do 1o Encontro do GT de Lexicologia, Lexicografia e Terminologia da ANPOLL, Recife: Fac. Letras/UFRJ, 1998. p.95-106.

. Neologia e tecnoletos, In: OLIVEIRA, A. M. de., ISQUERDO, A. N. (Orgs.) As ciências do léxico: lexicologia, lexicografia e terminologia. Campo Grande: Ed. UFMS, 1998. p.23-29.

ARNTZ, R. Intrucción a la terminologia. Madrid: Pirámide, 1995.

AUBERT, F. H. Introdução à metodologia da pesquisa terminólogica bilingüe. 2. ed. São Paulo: FFLCH/CITRAT, 2001. 103 p. - (Cadernos de terminologia, 2) ISBN 85-7506-031-7

BAKER, C.; COKELY, D. American Sign Language: A Teacher's resource text on grammar and culture. Maryland: TJ Publishers, 1980.

BASÍLIO, M. Teoria Lexical. Série Princípios, 8.ed. São Paulo: Editora Ática, 2007.

BARBOSA, M. A. Léxico, produção e criatividade: processos do neologismo. São Paulo: global, 1981. 
BARROS, L. A. Curso Básico de Terminologia. São Paulo: Edusp, 2004.

BARROS, M. E. ELiS: sistema brasileiro de escrita das línguas de sinais. Porto Alegre: Penso, 2015.

; AGUIAR, M. S. Metonímia e iconicidade nos nomes de espécies animais na Libras. Disponível em: $<$ http://www.simelp.letras.ufg.br/anais/simposio_44.pdf $>$. Acesso em: 12 set. 2014.

BATTISON, M. R. Lexical Borrowing in American Sign Language. Maryland: Linstok Press, 2003.

BAUER, L. English Word-formation. United Kingdom at University Press: Cambrigde, 1983. ISBN 0521241677.

BECHARA, E. Moderna gramática portuguesa. 37. ed. Rio de Janeiro: Nova Fronteira, 2009.

BENCZES, R. Setting limits on creativity in the production and use of metaphorical and metonymical compounds. In: ONYSKO, A; MICHEL, S. (Eds.) Cognitive Perspectives on word formation. Berlin: De Gruyter Mouton, 2010.

BRENNAN, M. Word formation in British Sign Language. Stockholm: University of Stockholm, 1990.

BIDERMAN, M. T. C. Terminologia e Lexicografia. TradTerm. V.7, p.153 -181), 2001.

BIENVENU, M. J. Developing a prototype for a monolingual ASL dictionary. Doctor of Philosophy in Interdisciplinary Studies with a specialization in Linguistics, Union Institute and Universtiy Graduate College, 2003.

BOULANGER, J-C, Convergências e divergência entre a lexicografia e a terminografia. In: LIMA, M. S.; RAMOS, P. C. (Org.). Terminologia e Ensino de segunda língua: Canadá e Brasil. Porto Alegre: ABECAN, 2001. 
BRASIL. Secretaria de Educação Fundamental. Parâmetros curriculares nacionais: apresentação dos temas transversais, ética. Brasília: MEC/SEF, 1998.

- Secretaria de Educação Fundamental. Parâmetros curriculares nacionais: apresentação dos temas transversais, ética. Brasília: MEC/SEF, 1997.

. Secretaria Nacional de Justiça. A Classificação Indicativa na Língua Brasileira de Sinais/ Organização: Secretaria Nacional de Justiça. - Brasília: SNJ, 2009.

. Decreto-lei n ${ }^{\circ} 5.626$, de 22 de dezembro de 2005. Regulamenta a Lei n. 10436 de 22/04/02 e o art. 18 da Lei 10.098 de 19/12/00.

. Lei $\mathrm{n}^{\circ} 10436$ de 22 de abril de 2002. Oficializa a LIBRAS.

. Decreto-lei ${ }^{\circ} 5.296$ de 02 de dezembro de 2004. Regulamenta as Leis n. 10.048, de $08 / 11 / 2000$ e n. 10.098 , de 19/12/2000.

. Lei ${ }^{\circ} 13.146$ de 6 de julho de 2015. Lei Brasileira de Inclusão da Pessoa com Deficiência (Estatuto da Pessoa com Deficiência).

. Lei n 9.795 de 27 de abril de 1999. Lei da Educação Ambiental e da Política Nacional de Educação Ambiental.

CÂMARA, Projeto de Lei 13/2010, 2010. Disponível em: $<$ http://www.cmfi.pr.gov.br/projetos.php?p2=1079>. Acesso em: 10 de jan. 2016.

. CÂMARA, Projeto de Lei 90/2013, 2013. Disponível em: $<$ http://cmspbdoc.inf.br/iah/fulltext/projeto/PL0090-2013.pdf >. Acesso 10 jan. 2016.

- Secretaria de Direitos Humanos da Presidência da República. Atualiza a nomenclatura do Conselho Nacional dos Direitos da Pessoa Portadora de Deficiência CONADE. Portaria n. 2.344, de 3 de novembro de 2010. DOU: Diário Oficial da República Federativa do Brasil. 
Instituto Brasileiro de Geografia e Estatística. Vocabulário Básico de Recursos Naturais e Meio Ambiente. Rio de Janeiro: IBGE, 2004;

CABRÉ CASTELLVÍ, M. T. La clasificación de neologismos: una tarea compleja. In: Alfa: Revista de Lingüística / UNESP - Universidade Estadual Paulista -Alfa, São Paulo, 50 (2): 1$281,2006$.

- La terminologia. Teoría, metodologia, aplicaciones. Barcelona: AntàrtidaEmpúries 1993.

. La terminología. Representación y comunicación, Barcelona, IULA, Universitat Pompeu Fabra, 1999.

. FELIU, J. (eds.) (2001): La terminología científico-técnica: Reconocimiento, análisis y extracción de información formal y semántica. Barcelona: IULA, Universitat Pompeu Fabra.

CACCAMISE, F.; LANG, H. G. Signs for Science and Mathematics: A resource book for teachers and students. Ed. D National Techinal Institute for the Deaf - Rochester Institute of Techonology. Rochester: NY. 2000.

CALVET, J-1. Sociolinguística: uma introdução crítica. São Paulo: Parábola, 2002. . Política Linguística. São Paulo: Parábola: IPOL, 2007.

CAMPEllo, A. R. S. Aspectos da visualidade na educação de surdos. 2008. 245 f. Tese (doutorado) - Universidade Federal de Santa Catarina, Pós-Graduação de Educação.

CAPOVILlA, F. C. \& RAPHAEL, W. D. Dicionário Enciclopédico Ilustrado Trilíngue da Língua de Sinais Brasileira - LIBRAS. Vol 1 e 2SP: EDUSP. 2001.

; MACEDO, E. C. Manual ilustrado de sinais e sistema de comunicação em rede para surdos. São Paulo, Edipusp, 1998. 
CARVALHO, O. L. S. Dicionários escolares: definição oracional e texto lexicográfico . in: CARVALHO, O. L. S e BAGNO. Dicionários escolares: políticas, formas e usos. São Paulo: Parábola. 2001.

; MARINHO, M. L. Contribuições da lexicografia ao contexto educacional bilíngue de surdos. In: SALLES, H. M. M. L. de A. (Coord.). Bilinguismo dos surdos: questões linguísticas e educacionais. Goiânia: Cânone, 2007.

CASTILHO, A. T. Nova gramática do português brasileiro. São Paulo: Contexto, 2010.

CHOMSKY, N. Aspects of the Theory of Sintax. Massachusetts: The MIT Press, 1965.

CLAS, A. A pesquisa terminológica e a formulação de parâmetros em função das necessidades dos usuários. In: As ciências do léxico: Lexicologia, Lexicografia, Terminologia. V. II. Campo Grande, MS: Ed. UFMS, 2004.

COLLIN, P. H. Dictionary of Environment \& Ecology. London: Bloomsbury Publishing, 2004.

COLOMBIA. Instituto Nacional para Sordos. Diccionario Básico de la Lengua de Señas Colombiana. Ministerio de Educación Nacional. 2006.

CORREIA, M. Os Dicionários Portugueses. Lisboa: Editorial Caminho, 2009.

. A terminologia em Portugal e países de língua portuguesa em África, 2005, pp. 15-20. Disponível em: <http://www.iltec.pt/pdf/wpapers/2005-mcorreia-terminometro1.pdf>. Acesso em: 14 dez. 2015.

; ALMEIDA, G. M'. B. Neologia em português. São Paulo: Parábola Editorial, 2012.

COSTELLO, E. House Webster's American sign language dictionary. Illustrated by Lois Lenderman, Paul M. Setzer. New York: Random House, 1994. 
. House Webster's American Sign Language Medical Dictionary. New York:

Random House, 2000.

. House Webster's American Sign Language Computer Dictonary. New York:

Random House, 2001.

. House Webster's American Sign Language Legal Dictionary. New York:

Random House, 2003.

CROFT, W; CRUSE, D. A. Cognitive Linguistics. New York: Cambridge University Press, 2004.

DAMÁZIO, M. F. M. Atendimento Educacional Especializado: Pessoa com Surdez. Brasília: SEESP/SEED/MEC, 2007.

DELBECQUE, N. Linguística Cognitiva: compreender como funciona a linguagem. Lisboa: Instituto Piaget, 2006.

DUBOIS, J.; EDELINE, F.; KLINKENBERG; MINGUET, P.; PIRE,F. e TRINON, H. Retórica Geral. Tradução de C. F. MOISÉS, D. COLOMBINI e E. De BARROS. Coordenação e revisão geral da tradução M. MOISÉS. São Paulo: Cultrix, 1970.

DOUETTES, B. B. Tradução na criação de sinais-termo religiosos em Libras e uma proposta para a organização de glossários terminológicos semibilíngues. 2015. 440 f. Dissertação (mestrado) - Programa de Pós-graduação em Estudos da Tradução, Universidade Federal de Santa Catarina.

DUQUE, P. H. Teoria dos protótipos, categoria e sentido lexical. Disponível em: $<$ http://www.filologia.org.br/revista/artigo/7(21)13.htm>. Acesso em: 21 de jul. 2013

DURAN, Magali S. e XATARA, Claudia M. (2005). Dicionários semibilíngues: uma inovação? In: Revista de Estudos Linguísticos. Belo Horizonte, v. 13, n. 1 p. 45-57, jan./jun. Disponível em: 
$<$ http://www.periodicos.letras.ufmg.br/index.php/relin/article/download/2398/2352>. Acesso em: 10 nov 2015.

EMMOREY, K (Ed). Perspectives on classifier constructions in sign languages. New Jersey: Lawrence Erlbaum Associates, Publishers, 2003.

FAULSTICH, E. PASSEGI, L. A. A construção da definição - abordagem semântica. Trabalho apresentado no II Simpósio Latino-americano de Terminologia. Brasília: IBICT, 1990. (ms)

A construção da definição - abordagem pragmática. Trabalho apresentado no II Simpósio Latino-americano de Terminologia. Brasília: IBICT, 1990. (ms)

FAULSTICH, E. Para gostar de ler um dicionário. In: RAMOS, Conceição de Maria de Araujo et alli (Org.). Pelos caminhos da dialetologia e da sociolinguística: entrelaçando saberes e vida - homenagem a Socorro Aragão. São Luís, MA: EDUFMA, 2010. p. 166 185

Avaliação de dicionários: uma proposta metodológica. Organon, Porto Alegre, 2011, v.25, n. 50, p. 181-220.

. Modalidade oral-auditiva versus modalidade vísuo-espacial sob a perspectiva de dicionários na área da surdez. In: SALLES, H. M.M. Lima (org.) Bilinguismo dos surdos: questões linguísticas e educacionais. cap. 6. GO: Cânone, 2007, p.119-142.

- Redes de remissivas em um glossário técnico. In: Léxico e Terminologia (Coletânea de Textos). Universidade de Brasília, 1993, p. 174-184.

. A socioterminologia na comunicação científica e técnica. In: Ciência e Cultura Terminologia. Editora Ideia N.02, 2006.

Análise operacional de esquemas contextuais: o campo lexical e a moldura. Acta Semiotica et Linguística, v. 15, p. 191-200, 2010a. 
. Nota lexical (2012). Disponível em: <http://www.centrolexterm.com.br>. Acesso em 17 de agosto de 2015.

- Características conceituais que distinguem o que é de para que serve nas definições de terminologias científica e técnica. In: ISQUERDO, A. N; DAL CORNO, G. O. M. (Orgs.). As ciências do léxico: lexicologia, lexicografia, terminologia, Vol. VII. Campo Grande, MS: Ed. UFMS, 2014.

- Pressupostos de lexicografia bilíngue como base para dicionários de Libras $X$ Português. Conferência. In: II Simpósio de Língua de Sinais e Bilinguismo; III Encontro Nacional do Gelco FINATEC - Campus Darcy Ribeiro/UnB, 2006.

FARIA-NASCIMENTO, S.P. Representações Lexicais da Língua de Sinais Brasileira. Uma Proposta Lexicográfica. Brasília, 2009. 290 f. Tese (doutorado) - Instituto de Letras, Universidade de Brasília.

. A organização dos morfemas livres e presos em LSB: reflexões preliminares. In: QUADROS, R. M., STUMPF, M. R. e LEITE, T. A. (orgs.) Estudos da língua brasileira de sinais. Série Estudos de Língua de Sinais. V.I. Florianópolis: Insular. 2013.

. Metáfora na LSB: Debaixo dos panos ou a um palmo de nosso nariz? ETD Educação Temática Digital, Campinas, v. 7, n. 2, p. 179-1999, jun. 2006.

; CORREIA, M. Um olhar sobre a morfologia dos gestos. Lisboa: UCP, 2011. (Coleção: Língua Gestual Portuguesa - n²15).

; NASCIMENTO, C. B. Introdução aos estudos linguísticos: língua de sinais brasileira e língua portuguesa. Florianópolis: UFSC. 2010. ISBN: 978-85-60522-25-5

FARIAS, V. S. Sobre a definição lexicográfica e seus problemas: fundamentos para uma teoria geral dos mecanismos explanatórios em Dicionários Semasiológicos. Porto Alegre, 2013. 399 f. Tese (doutorado) - Pós-Graduação em Letras da Universidade Federal do Rio Grande do Sul. 
FELBER, Helmut. Terminology Manual. Paris: Unesco: Infoterm, 1984.

FELIPE, T. A. Os processos de formação de palavras na libras. ETD - Educação Temática Digital, Campinas, v. 7, n. 2, p. 200-217, jun. 2006.

FELTES, H. P. M. Semântica Cognitiva: ilhas, pontes e teias. Porto Alegre: EDIPUCRS, 2007.

FELTRINI, G. M. Aplicação de modelos qualitativos a educação científica de surdos. Brasília, 2009. 222 f. Dissertação (Mestrado em Ensino de Ciências) - Instituto de Ciências Biológicas, Universidade de Brasília.

FERREIRA, L. Por uma gramática de Línguas de Sinais [reimpr.]. Rio de Janeiro: Temo Brasileiro, 2010.

FIGUEIREDO SILVA, M. C.; SELL, F. F. S. Algumas notas sobre os compostos em português brasileiro e em libras, 2009. Disponível em: $<$ http://linguistica.fflch.usp.br/sites/linguistica.fflch.usp.br/files/FIGUEIREDOSILVASELL.pdf $>$. Acesso em: 20 de janeiro 2016.

FINATTO, M. J. B. A definiç̧ão terminológica do dicionário termisul: expressões linguísticas de relações conceituais complexas. In: OLIVEIRA, A. M. P. P.; ISQUERDO, A. N. As ciências do léxico: lexicologia, lexicografia, terminologia. Campo Grande, MS: Ed. UFMS, 2001.

FLEISCHMANN, M. E. S; PÉREZ, R. G. Manos con voz: Diccionario de Lengua de Señas Mexicana. México: Consejo Nacional para Prevenir La Discriminación, 2011.

GAMA, F. J. Iconographia dos Signaes dos Surdos-Mudos. Rio de Janeiro: INES, 2011. (Série Histórica do Instituto Nacional de Educação de Surdos; 1)

GEWANDSZNAJDER, F. Projeto Teláris: ciências ensino fundamental. São Paulo: Ática, 2015 . 
GLICKMAN, K. Deaf Proverbs: A proverbial Professor's Points to Ponder. Maryland: DEAFinitely Yours Studio, 1999.

GOTTI, M. Direitos Linguísticos dos Surdos, garantidos pela Legislação Brasileira: Ações efetivadas no período de 2002 a 2014. Aula inaugural da Licenciatura em Língua de Sinais Brasileira - Português Segunda Língua, ministrada no Auditório do Instituto de Letras da Universidade de Brasília, no dia 13 de Março de 2015.

GROSJEAN, F. (2008). The bilingualism and biculturalism of the deaf. In F. Grosjean, Studying bilinguals (Ch. 13). Oxford, New York: Oxford University Press.

HADOT, P. Wittgenstein e os limites da linguagem. São Paulo: É Realizações Ed, 2014.

HARTMANN, R. R. K. Lexicography: Principles and Practice. London: Academic Press, inc. 1983.

HONORA, M.; FRIZANCO M. L. E. Livro Ilustrado de Língua Brasileira de Sinais: Desvendando a comunicação usada pelas pessoas com surdez. São Paulo: Ciranda Cultural, 2009, 2010 e 2011.

HOUAISS, A.; VILlAR, M. S. Dicionário Houaiss de Língua Portuguesa. Elaborado pelo Instituto Antônio Houaiss de Lexicografia e Banco de Dados da Língua Portuguesa S/C Ltda. Rio de Janeiro: Objetiva, 2009.

ILARI, R. Introdução ao estudo do léxico: brincando com as palavras. São Paulo: Contexto, 2008.

ISO 704. International Standard. Terminology work: Principles and methods. Switzerland, 2000, 16 p.

KLEIBER, G. La Semántica de los prototipos: categoría y sentido léxico.Traducción de Antonio Rodríguez Rodríguez. Madri: Visor Libros, 1995. 
KRISTOFFERSEN, J. H; TROELSGARD, T. The electronic lexicographical treatment of sigh languages: The Danish Sign Language Dictionary" de Kristoffersen e Troelsgard. In: GRANGER, Sylviane; PAQUOT, Magali (org). Electronic Lexicography. United Kingdom: Oxford, 2012. p. $293-316$

An electronic dictionary of Danish Sign Language, 2006. Disponível em: $<$ http://www.editora-arara-azul.com.br/ebooks/catalogo/45.pdf $>$. Acesso em: 16 jul 2014.

LABORIT, E. O vôo da Gaivota. Paris: Editora Best Seller, 1994.

LAKOFF, G. \& JOHNSON M. Metáforas de la vida cotidiana. Catedra: Teorema, 2012.

LANE, H; GROSJEAN, F. Recent Perspectives on American Sign Language. New Jersey: Lawrence Erlbaum Associates, 1980.

LARA, L. F. Término y Cultura: hacia una teoria del término: In: CABRÉ, M.T (Org.) Terminologia y modelos culturales. Barcelona: Institut Universitari de Linguística Aplicada, 1999, p. 39-60.

LIMA, V. L. S. Língua de Sinais: proposta terminológica para a área de Desenho Arquitetônico. 2014. 278 f. Tese (Doutorado em Linguística) - Faculdade de Letras, Universidade Federal de Minas Gerais.

LIRA, G; FELIPE, T. Dicionário da Língua Brasileira de Sinais versão 2.1. INES Acessibilidade Brasil. Coordenação Geral de Guilherme de Azambuja Lira. 2008. Disponível em: http://www.acessibilidadebrasil.org.br/libras/>. Acesso em: 28 mai. 2014.

LUQUE DURÁN, J. D. Aspectos universales y particulares del léxico de las lenguas del mundo. Método Ediciones, Granada, 2001a.

MAIA, O. B. Vocabulário Ambiental Infantojuvenil. Colaboração: Tino Freitas; ilustrações: vários ilustradores. Brasília: Ibict, 2013. 
MARINHO, M. L. O Ensino da Biologia: o intérprete e a geração de sinais. Brasília, 2007. 144 f. Dissertação (Mestrado em Linguística) - Instituto de Letras, Universidade de Brasília.

. CARVALHO, O. L. S. Contexto educacional bilíngue e a criação de termos científicos na Língua Brasileira de Sinais: experimentos nas áreas da Biologia e da Física. In: SAlleS, P. S. B. A; GAUCHE, R (Org.) Educação Científica, inclusão social e acessibilidade. Goiânia: Cânone Editorial, 2011.

MARTELOTA, M. E; ALONSO, K. S. Funcionalismo, cognitivismo e a dinamicidade da língua. In: SOUZA, E.R.(org.) Funcionalismo Linguístico: Novas tendências teóricas. São Paulo: Contexto, 2012.

MARTINS, M; FERREIRA, J. P; MINEIRO, A. et al (ver ABNT). Os dicionários e os avatares gestuais: o que são, como se fazem e para que servem. Lisboa: Universidade Católica, 2012. (PRO_LGP: Licenciatura em Língua Gestual Portuguesa)

MARTINS, A. C. Lexicografia da língua de sinais brasileira do Rio Grande do Sul. 2012. Dissertação (Mestrado em Psicologia Experimental) - Instituto de Psicologia, Universidade de São Paulo, São Paulo, 2012. Disponível em: $<$ http://www.teses.usp.br/teses/disponiveis/47/47132/tde-15032013-104524/>. Acesso em: 28 jan. 2016.

MATTOSO CAMARA JR. J. Dicionário de linguística e gramática. Petrópolis: Vozes, 1978.

MENIS, V; LINS, S. D. Manual de sinais bíblicos: o clamor do silêncio. Rio de Janeiro: Junta de missões nacionais da convenção batista brasileira, 1991.

MOREIRA, D. A. Um estudo introdutório sobre o desenvolvimento dos repertórios léxicos da língua de sinais brasileira a partir da elaboração da definição lexicográfica. Florianópolis, 2015. 221 f. Dissertação (mestrado) - Programa de Pós-Graduação em Estudos da Tradução, Universidade Federal de Santa Catarina.

NARVAES, P. Dicionário ilustrado de meio ambiente. Ed. São Caetano do Sul, SP: Yendis Editora, 2012. 
NASCIMENTO, C. B. Empréstimos Linguísticos do Português na Língua de Sinais Brasileira - LSB: Línguas em Contato. Brasília, 2010. 109 f. Dissertação (mestrado) Instituto de Letras, Universidade de Brasília.

; FAULSTICH, E. Linguas em Contato: Empréstimos do Português na Língua de Sinais Brasileira. Saarbrücken: Novas edições acadêmicas, 2016.

; FAULSTICH, E. O léxico da área ambiental na Língua de Sinais Brasileira: busca de mecanismos de designação de termos. In: Caderno de resumos expandidos X ENGTLEX IX Encontro Intermediário do GT de Lexicologia, Lexicografia e Terminologia da ANPOLL, 2013. Disponível em: $<$ http://150.164.100.248/gtlexNovo/CMS/index.asp?pasta=gtlexnovo\&path=201362820928.a sp\&title $=$ IX\%20ENGTLEX\%20-\%20Resumos\%20Expandidos.>. Acesso em: 22 outubro 2014.

NEVES, M. H. M. A gramática funcional. São Paulo: Martins Fontes, 1997.

OATES, E. Linguagem das mãos. Rio de Janeiro: Gráfica Editora Livro S. A, 1969. .; HOEMANN, H. W.; HOEMANN, S. A. Linguagem de sinais do Brasil. Porto Alegre: Edição dos autores, 1983.

ONYSKO, A; MICHEL, S. (Eds.). Cognitive perspectives on word formation. Berlin/New York: De Gruyter Mouton, 2010.

ORMOND, J. G. P. Glossário de termos usados em atividades agropecuárias, florestais e ciências ambientais. Rio de Janeiro: BNDES, 2006.

PEIRCE, C. S. Semiótica. [tradução]. São Paulo: Perspectiva, 2010.

PEREIRA FILHO, T. Glossário de termos técnicos em Libras: eletrotécnica. Brasília: SENAI /DN, 2011. 
PETERSON, J. E.; ENSMINGER, J. Aprendendo a comunicar. Fortaleza: Edição do autor, 1984. . Comunicando com as mãos. Fortaleza: Edição do autor, 1987.

PIZZIO, A. L, et. al. Língua Brasileira de Sinais III. Florianópolis: CCE - UFSC, 2009.

PONTES A. L. Multimodalidade em dicionários escolares in: ISQUERDO, A. N.; BARROS, L. A. (Orgs.). As Ciências do Léxico: Lexicologia, Lexicografia e Terminologia. (vol V). Campo Grande, MS: Ed. UFMS, 2010.

PROMETI RIBEIRO, D. Glossário bilíngue da língua de sinais brasileira: Criação de sinais dos termos da música. Brasília, 2013. 106 f. Dissertação (Mestrado em Linguística) Instituto de Letras, Universidade de Brasília.

QUADROS, R. M; KARNOPP. L. B. Lingua de sinais brasileira: estudos linguísticos. Porto Alegre: Artmed. 2004.

QUADROS, R. M; PIZZIO, A. L; REZENDE, P. L. F. Língua Brasileira de Sinais II. Florianópolis: UFSC, 2008.

QUENQUA, D. Pushing Science's Limits in Sign Language Lexicon. Disponível em: $<$ http://www.nytimes.com/2012/12/04/science/sign-language-researchers-broaden-sciencelexicon.html?pagewanted=all\&_r=0 $>$ Acesso em: 15 de agosto de 2014 .

RAMOS COSTA, M. Proposta de modelo de enciclopédia visual bilíngue juvenil: enciclolibras. Brasília, 2012. 151 f. Dissertação (Mestrado em Linguística) - Instituto de Letras, Universidade de Brasília.

REAGAN, T. Language planning and language policy for Sign Languages.. In: RICENTO, T (Ed)An introduction to language policy: theory and method. Blackwell Publishing. 2006. 
ROBERTSON. X. A; QUINTELA, D. A; RAMÍREZ I. C. Diccionario Bilingue Lengua de Señas Chilena - Español: Tomo II. Santiago: Universidad Metropolitana de Ciencias de la Educación. 2009.

PREIS, R. Terminologia e desenvolvimento: a experiência com um glossário didático para o meio ambiente. In: IV Simpósio Iberoamericano de Terminología, 1994, Buenos Aires. Actas do IV Simpósio Iberoamericano de Terminología. Bueno Aires, 1994.

SACKS, O. W. Vendo vozes: uma viagem ao mundo dos surdos. São Paulo: Companhia das Letras, 1998.

SAITO, C. H. (Org.). Educação Ambiental: PROBIO. Brasília: Departamento de Ecologia da Universidade de Brasília/MMA, 2006.

SILVIA, L. F. P. Estudo crítico da representação visual do léxico em dicionários infantis ilustrados. Brasília, 2006. 139 f. Dissertação (Mestrado em Linguística) - Instituto de Letras, Universidade de Brasília.

SCHERMER, T.; KOOLHOF, C. The first national Dutch Sign Language (NGT) Dictionary in book form: Van Dale Basiswoordenboek Nederlandse Gebarentaal Disponível em: $<$ http://www.euralex.org/elx_proceedings/Euralex2010/149_Euralex_2010_11_SCHERMER $\% 20$ KOOLHOF_The $\% 20$ first $\% 20$ national\%20Dutch\%20Sign\%20Language_NGT_Dictionar y\%20in\%20book\%20form_Van\%20Dale\%20Basiswo.pdf $>$. Acesso em: 16 jul. 2014.

SCHIERHOLZ, S. J. Lexicografia de Especialidade e Terminografia. In: ISQUERDO, A. N.; SEABRA, M. C. T.C. As Ciências do Léxico: Lexicologia, Lexicografia e Terminologia VI (org). Campo Grande, MS: Ed. UFMS, 2012.

SOFIATO, C. G. O desafio da representação pictórica da Língua de Sinais Brasileira. Campinas, 2005. 114 f. Dissertação (Mestrado em Artes) - Instituto de Artes, Universidade Estadual de Campinas. 
; REILY, L. H. Dicionarização da língua brasileira de sinais: estudo comparativo iconográfico e lexical. Educação e Pesquisa, vol. 40, núm. 1, enero-marzo, 2014, pp.109-126. Universidade de São Paulo. São Paulo, Brasil.

SOUSA, S. F; SILVEIRA, H. E. Terminologias Químicas em Libras: A Utilização de Sinais na Aprendizagem de Alunos Surdos. In: Química Nova na Escola. vol. 33, n 1, fevereiro 2011.

STERNBERG, M. L. A. American Sign Language dictionary. New York: Perennial Library. 1987. ISBN 0-06-091383-5

. American Sign Language dictionary: A comprehensive Dictionary. 1981. New York: Harper \& Row. ISBN 0-06-014097-6

StOKOE, C. W; CASTERLINE, D. C; CRONEBERG, C. G. A Dictionary of American Sign Language: on linguistic principles. United States of America: Linstok Press, 1965.

STUMPF, M. R; OLIVEIRA, J. S; MIRANDA, R. D. Glossário Letras Libras: A trajetória dos sinalários no curso: como os sinais passam a existir? In: Letras Libras: ontem, hoje e amanhã. Org. QUADROS, R. M. Florianópolis: Ed. da UFSC, 2014.

SUTTON-SPENCE. R; WOLL, B. The Linguistics of British Sign Language: An Introduction. New York: Cambrige University Press.1999.

TAUB, S. F. Language from the body: Iconicity and Metaphor in American Sign Language. New York: Cambridge University Press, 2004.

TEMOTEO, J. G. Lexicografia da língua de sinais brasileira do nordeste. 2012. Tese (Doutorado em Psicologia Experimental) - Instituto de Psicologia, Universidade de São Paulo, São Paulo, 2012. Disponível em: $<$ http://www.teses.usp.br/teses/disponiveis/47/47132/tde-15032013-113527/>. Acesso em: 28 jan. 2016. 
TENNANT, R. A; BROWN, M. G. The American Sign Language Handshape Dictionary. Washington: Gallaudet University, 1998.

TERRENCE J. O. Dictionary of Sign Language Terms. Utah: T. J. Publishers. 1980.

TESTEMUNHAS DE JEOVÁ. Linguagem dos sinais. Cesário Lange: Sociedade Torre de Vigia de Bíblias e Tratados, 1992.

TOVAR, L. A. La necesidad de planificar una norma lingüística en lengua de señas para usos académicos. Escuela de Ciencias del Lenguaje Universidad del Valle, Cali, Colombia, LENGUA Y HABLA Nº 8. 2003-2004.

. La creación de neologismos en la lengua de señas colombiana, 2010. Disponível em: <http://bibliotecadigital.univalle.edu.co/bitstream/10893/3510/1/Art01-277.pdf> Acesso em: 13 abr. 2013.

VALLI, C. The Gallaudet Dictionary of American Sign Language. Washington: Gallaudet Univesity Press. 2005.

; LUCAS, C. Linguistics of American Sign Language. Washington: Gallaudet University. 2000.

. et al. Linguistics of American Sign Language: an introduction. Washington: Gallaudet University Press, 2011.

VIEIRA, S. Como escrever uma tese. São Paulo: Atlas, 2008.

WATANABE, S. (coor.). Glossário de Ecologia. São Paulo: Academia de Ciências do Estado de São Paulo, Conselho Nacional de Desenvolvimento Científico e Tecnológico da Fundação de Amparo à Pesquisa do Estado de São Paulo. Secretaria da Ciência e Tecnologia. ACIESP, 1987. Publicação $n^{\circ} 57$. 
WEINREICH, U. Definição Lexicográfica em Semântica Descritiva. Alfa, São Paulo, 1984.Disponível em: <http://piwik.seer.fclar.unesp.br/alfa/article/viewFile/3680/3446>. Acesso em: 13 mar. 2014.

WELKER, H. A. Lexicografia pedagógica: definições, história, peculiaridades. In: Lexicografia pedagógica pesquisas e perspectivas. (Orgs.) XATARA, C; BEVILACQUA, C; HUMBLÉ, P. Florianópolis: UFSC - NUT. 2008.

WILCOX, S. Cognitive iconicity: Conceptual spaces, meaning, and gesture in signed languages, $2004 . \quad$ Disponível em: $<$ http://www.unm.edu/ wilcox/UNM/Research_files/WilcoxCogIconicity.pdf $>$. Acesso em: 20 fev. 2016.

; MORFORD, J. P. Empirical Methods in signed language research. In: (Edited by) GONZALEZ-MARQUEZ et al. Methods in Cognitive Linguistics. Amsterdam/Philadephia: John Bejamins Publishing Company, 2007.

WITTGENSTEIN, Investigações filosóficas. Petrópolis: Vozes, 1994a. . Tractatus lógico-philosophicus. 2. ed. São Paulo: EDUSP, 1994b.

WOODWARD, J. SIGNS of Sexual Behavior: an introduction to sex-related vocabulary in American Sign Language. T.J. Publishers. 1979. DVD.

SIGNS of Drug use: an introduction to drug and alcohol vocabulary in American Sign Language. T.J. Publishers. 1980. DVD.

ZAMBONI, L. M. S. Cientista, jornalista e a divulgação científica: subjetividade e heterogeneidade no discurso da divulgação científica. Campinas, SP: Autores Associados, 2001. (apoio FAPESP)

ZWITSERLOOD, I. Sign Language Lexicography in the early $21 \mathrm{ST}$ century and a recently published Dictionary of Sign LANGUAGE OF THE NETHERLANDS Disponível em: 
$<$ http://pubman.mpdl.mpg.de/pubman/item/escidoc:570575:3/component/escidoc:570574/zwi tserlood_review_int_j_lex_2010.pdf>. Acesso em: 16 jul 2014.

Sites

ALMEIDA, D. E. Site Legenda Libras. Disponível em: $<$ http://www.legendalibras.com.br/index.html>. Acesso em: 18 jul. 2013.

ASL-STEM FORUM. Disponível em: < https://aslstem.cs.washington.edu>. Acesso em: 13 de mai. 2015.

AULETE DIGITAL, sem data. Disponível em: < http://www.aulete.com.br >. Acesso em: 17 de jun. 2013.

BASE Nacional Comum Curricular. Disponível em: $<$ http://basenacionalcomum.mec.gov.br/\#/site/base/o-que>. Acesso em: 5 jan. 2016.

BRITISH SIGN Language Glossaries of Curriculum Terms. Disponível em: $<$ http://www.ssc.education.ed.ac.uk/bsl/about.html>. Acesso em: 5 nov. 2015.

DICIONÁRIO da Língua Brasileira de Sinais (versão 2.1 - web - 2008). Disponível em: $<$ http://www.acessobrasil.org.br/libras/ >. Acesso em: 26 fev. 2016.

DICIONÁRIO de Libras - Palavras e Termos da Biologia da Universidade Tecnológica Federal do Paraná (UTFPR). Disponível em: $<$ http://epeem.cp.utfpr.edu.br/site/?page_id=8.>. Acesso em: 1 set. 2015.

DICIONÁRIO terminológico em LGP. Disponível em: $<$ http://pro-lgp.com/dicionario/ > . Acesso em: 26 out. 2015.

ELIX: Le dictionnaire vivant en langue des signes. Disponível em: $<$ https://www.elix1sf.fr/spip.php?page $=$ signes\&id_article $=190514 \&$ type_vue $=$ unitaire\&lang $=\mathrm{fr}>$. Acesso em: $14 \operatorname{dez} 2015$. 
EMPRESA Brasileira de Pesquisa Agropecuária (EMBRAPA). Disponível em: $<$ https://www.embrapa.br>. Acesso em: 2 mar. 2016.

FOLHA de São Paulo. Disponível em: $<$ http://www.folha.uol.com.br>. Acesso em: 19 jan. 2014.

FOLHA do Meio Ambiente. Diponível em: $<$ http://www.folhadomeio.com.br/publix/fma/folha/2016/02/>. Acesso em: 4 fev. 2016.

GLOSARIO Ciencias en Señas. Disponível $<$ http://www.cienciaensenas.org/index.php?option=com_content\&view=article\&id=19\&Itemi $\mathrm{d}=27>$. Acesso em: $11 \mathrm{fev} .2014$.

GLOSSÁRIO LIBRAS. Disponível em: < http://www.glossario.libras.ufsc.br>. Acesso em: 20 de dez 2015.

GREENPEACE. Disponível em: <http://www.greenpeace.org/brasil/pt/> Acesso em: 14 mai. de 2013.

MINISTÉRIO do Meio Ambiente, do Instituto Brasileiro do Meio Ambiente e dos Recursos Naturais Renováveis (IBAMA). Disponível em: <http://www.mma.gov.br>. Acesso em: 20 fev. 2014.

PLANETA SUSTENTÁVEL. Disponível em: <http://planetasustentavel.abril.com.br $>$. Acesso em: 13 jun. 2014.

SPREAD the sign. Disponível em: <http://www.spreadthesign.com/br/>. Acesso em: $21 \mathrm{de}$ jul. 2013. 
APÊNDICES 
ANEXOS 